\title{
Arbeid, gezondheid en verzuim als voorspellers van uitval uit het werk
}

Citation for published version (APA):

de Winter, C. R. (1991). Arbeid, gezondheid en verzuim als voorspellers van uitval uit het werk. [Doctoral Thesis, Maastricht University]. Nederlands Instituut voor Praeventieve Gezondheidszorg TNO.

https://doi.org/10.26481/dis.19910523cw

Document status and date:

Published: 01/01/1991

DOI:

$10.26481 /$ dis. $19910523 \mathrm{cw}$

Document Version:

Publisher's PDF, also known as Version of record

\section{Please check the document version of this publication:}

- A submitted manuscript is the version of the article upon submission and before peer-review. There can be important differences between the submitted version and the official published version of record.

People interested in the research are advised to contact the author for the final version of the publication, or visit the DOI to the publisher's website.

- The final author version and the galley proof are versions of the publication after peer review.

- The final published version features the final layout of the paper including the volume, issue and page numbers.

Link to publication

\footnotetext{
General rights rights.

- You may freely distribute the URL identifying the publication in the public portal. please follow below link for the End User Agreement:

www.umlib.nl/taverne-license

Take down policy

If you believe that this document breaches copyright please contact us at:

repository@maastrichtuniversity.nl

providing details and we will investigate your claim.
}

Copyright and moral rights for the publications made accessible in the public portal are retained by the authors and/or other copyright owners and it is a condition of accessing publications that users recognise and abide by the legal requirements associated with these

- Users may download and print one copy of any publication from the public portal for the purpose of private study or research.

- You may not further distribute the material or use it for any profit-making activity or commercial gain

If the publication is distributed under the terms of Article $25 \mathrm{fa}$ of the Dutch Copyright Act, indicated by the "Taverne" license above, 


\title{
Arbeid, gezondheid en verzuim als voorspellers van uitval uit het werk
}

\author{
Work, health and absenteeism \\ to predict job drop-out
}

mei 1991 
Nederlands Instituit voor

Praeventieve Gezondheidszorg TNO

Wassenaarseweg 56, Leiden

Postadres:

Postbus 124

$2300 \mathrm{AC}$ LEIDEN

Telefoon: $071-181 \quad 181$

- 1991 Nederlands Instituut voor Praeventieve Gezondheidszorg TNO Publikatienummer: 91.012

Voor de rechten en verplichtingen van de opdrachtgever met betrekking tot de inhoud van dit rapport wordt verwezen naar de Algemene Voorwaarden van TNO. Niets uit deze uitgave mag worden verveelvoudigd, openbaar gemaakt, en/of verspreid door middel van druk, fotokopie, microfilm of op welke wijze ook zonder voorafgaande schriftelijke toestemming van het NIPG-TNO. 


\section{ARBEID, GEZONDHEID EN VERZUIM \\ ALS VOORSPELLERS VAN UITVAL UIT HET WERK}

Work, health and absenteeism to predict job drop-out

\section{PROEFSCHRIFT}

ter verkrijging van de graad van doctor aan de Rijksuniversiteit Limburg te Maastricht, op gezag van de Rector Magnificus, Prof. Mr. M.J. Cohen, volgens het besluit van het College van Dekanen, in het openbaar te verdedigen op donderdag, 23 mei 1991 om 16.00 uur

door

Cornelis Rabert de Winter 


\section{Promotor:}

Prof. Dr. H. Philipsen

Beoordelingscommissie:

Prof. Dr. F. Sturmans (voorzitter)

Prof. Dr. J.T. Allegro

Prof, Dr. Tj. de Boorder

Dr. A. Dijkstra

Dr. F. Nijhuis 
SUMMARY

LIJST VAN BIJZONDERE AFKORTINGEN

1. INLEIDING

1.1 Achtergrond en doelstelling

1.2 Verklarende en te verklaren variabelen, vraagstelling 5

1.2.1 Verklarende en te verklaren variabelen 5

1.2.2 Vraagstelling

1.3 Methode: prospectief epidemiologisch onderzoek 9

1.4 Relevantie van het onderzoek 11

1.4.1 Relevantie van het onderzoek in cijfers 11

1.4.2 Relevantie van het onderzoek voor de bedrijfsgezondheidszorg

1.4.3 Relevantie van het onderzoek voor het overheidsbeleid

1.5 De verdere hoofdstukken

2. LITERATUUR OVER ARBEIDSONGESCHIK THEID, VERVROEGD UITTREDEN EN ONTSLAGNAME

2.1 Inleiding

2.2 Arbeidsongeschiktheid

2.2.1 Wettelijke arbeidsongeschiktheidsregelingen

2.2.2 Diagnoses bij arbeidsongeschiktheid

2.2.3 Percentages arbeidsongeschiktheid

2.2.4 Economische oorzaken van arbeidsongeschiktheid

2.2.5 Bedrijfsgebonden oorzaken van arbeidsongeschiktheid

2.2.6 Persoonsgebonden oorzaken van arbeidsongeschiktheid

2.2.7 De invloed van arbeidsbelasting op het arbeidsongeschikt-worden

2.3 Vervroegd uittreden

2.3.1 Achtergrond en kenmerken van VUT-regelingen 36

2.3.2 Aantallen vervroegd uitgetredenen 37

2.3.3 Economische oorzaken van de VUT 38

2.3.4 Kenmerken van toetreders tot de VUT 41

2.4 Ontslagname 43

2.4.1 Wettelijk kader van ontslagname 43

2.4.2 Motieven voor ontslagname 43

2.4.3 Aggregatieniveau bij ontslagname/verloop 44

2.4.4 Modellen van ontslagname en verloop 45 
2.5 Conclusies uit de literatuur: werkhypothesen

2.5.1 Conclusies over arbeidsongeschiktheid

2.5.2 Conclusies over vervroegd uittreden

2.5.3 Conclusies over ontslagname

3.1 De in het onderzoek betrokken bedrijven

3.2 De respons bij het onderzoek

3.3 De gebruikte gegevens

3.4 Persoons - en functiekenmerken

3.5 Verklarende variabelen: verzuimgegevens

3.6 Verklarende variabelen: meningen over arbeid en gezondheid in somscores, VAG lange versie

3.6.1 Aard en inhoud van de somscores, VAG lange versie

3.6.2 Gemiddelde en spreiding van de somscores, VAG lange versie

3.6.3 Betrouwbaarheid van de somscores, VAG lange versie

3.6.4 Validiteit van de somscores

3.6.5 Twee groepen somscores: indices lange versie

3.7 Verklarende variabelen: meningen in somscores, VAG korte versie

3.7.1 Aard en inhoud van de VAG korte versie

3.7.2 Gemiddelde en spreiding van de VAG korte versie

3.7.3 Betrouwbaarheid van de VAG korte versie

3.7.4 Validiteit van de VAG korte versie

3.7.5 Twee groepen somcores, indices korte VAG

3.8 Verklarende variabelen: conclusie

3:9. Te verklaren variabelen

3.9.1 Aantallen vertrokken werknemers 91

3.9.2 Gemiddelde leeftijd bij vertrek 96

3.9.3 Vertrek in twee typen afdeling 98

3.9.4 Vertrek bij uitvoerend en leidinggevend personeel 99

3.10 Te verklaren variabelen: conclusie $\quad 102$

3.11 Analysetechnieken 102

3.11.1 Samenvatting van het analyseplan 106 
4.1 Voorspelling van arbeidsongeschiktheid

4.1.1 Verschillen tussen wel-en niet- arbeidsongeschikt

4.1.2 Variabelen in de tijd voor arbeidsongeschiktheid

4.1.3 Arbeidsongeschiktheid; voorspellend vermogen per variabele

4.1.4 Arbeidsongeschiktheid; voorspelling uit werknemersmeningen en verzuimgegevens

4.1.5 Arbeidsongeschiktheid en lange VAG: discussie

4.2 Voorspelling van vervroegd uittreden

4.2.1 Verschillen tussen wel- en niet-VUT

4.2.2 Variabelen in de tijd voor het vervroegd uittreden

4.2.3 Vervroegd uittreden; voorspellend vermogen per variabele

4.2.4 Vervroegd uittreden: voorspelling uit werknemersmeningen en verzuimgegevens

4.2.5 Vervroegd uittreden en lange VAG: discussie

4.3 Voorspelling van ontslagname

4.3.1 Verschillen tussen wel-en niet-ontslagname lange $\mathrm{VAG}$

4.3.2 Variabelen in de tijd voor ontslagname

4.3.3 Ontslagname: voorspellend vermogen per variabele

4.3.4 Ontslagname: voorspelling uit werknemersmeningen

4.3.5 Ontslagname en lange $V A G$ : discussie

5.1 Voorspelling van arbeidsongeschiktheid

5.1.1 Werschillen tussen niet-en wel-arbeidsongeschikten

5.1.2 Arbeidsongeschiktheid: voorspellend vermogen korte VAG

5.1.3 Arbeidsongeschiktheid: voorspelling uit korte $\mathrm{VAG}$ en verzümgegevens

5.1.4 Arbeidsongeschiktheid en korte VAG: discussie 
5.2 Voorspelling van vervroegd uittreden

5.2.1 Verschillen VAG tussen wel- en niet-VUT

5.2.2 VUT: voorspellend vermogen korte VAG

5.2.3 VUT: voorspelling uit de korte VAG en verzuim-

5.2.4 VUT en de korte VAG: discussie

5.3 Voorspelling van ontslagname

5.3.1 Verschillen tussen wel-en niet-ontslagname

5.3.2 Ontslagname: voorspellend vermogen korte VAG

5.3.3 Ontslagname: voorspelling uit korte $V A G$ en verzuimgegevens

5.3.4 Ontslagname en korte VAG: discussie

5.4 Korte VAG: algemene discussie

6. SAMENVATTING, CONCLUSIE EN AANBEVELINGEN

6.』 Samenvatting en conclusies

6.1.1 Arbeildsongeschiktheid

6.1.2 Vervroegd uittreden

6.1.3 Ontslagname

6.2 Aanbewelingen

6.2.1 Methoden van onderzoek

6.2.2 Signalering van naderende uitval

6.2.3 Nader onderzoek 


\section{SUMMARY}

The work force of four organizations totaling over 4500 employees, was followed for up to five years in an epidemiological study using a prospective design. The intention was to arrive at individual predictors of different ways of leaving the organization (disability, voluntary early retirement, and resignation), with prewention of unwanted dropout at the individual level as the primary aim. The secondary aim was to validate the questionnaire used (see below). Predictors were sought among employees" opinions on their health, work, and working conditions, and their absenteeism data. The opinions were asked at the outset by means of the Questionnaire on Work and Health (QWH) developed by the NIPG/TNO. The QWH comes in two forms, viz. an extensive (117-item) and a short (41item) form. These data are presented in the form of composite scores, i.e. problem levels pertaining to broad subject domains. These scores proved to possess sufficient construct validity, while the absenteeism data correspond to those in the general working population; hence both sets of data could be used as potential predictors of employment departure.

Except for resignation, the number of female employees in the data is too low to draw any conclusions. The outcomes of comparisons between departed and remaining employees are as follows. Disability shows striking group differences and has strong individual predictors in complaints on work strain, health, and illness behaviour; it is also predicted by an index summarizing these complaints, and by a time-lost measure of absenteeism. Within the group of older male employees (50 years and over, where disability incidence is highest), these complaints are better predictors of disability than absenteeism data. A combination of both sets of data (QWH-scores and absenteeism data), however, makes for stronger individual predictions. The predictions here are good enough to initiate preventive interventions. The QWH-scores regarding working conditons (physi$\mathrm{cal}$, social, and organizational) do not predict future disability, the relation working conditions - disability being indirect, mediated by health. The literature pertaining to voluntary early retirement led to the conjecture that future early retirees should have many work-related problems. This proved not to be the case. Complaints (QWH) and absence behaviour actually are on a lower level than in the non-early-retired of the same age. This outcome suggests that disability 
and voluntary early retirement are complementary phenomena. The relationships between absenteeism and employee opinions on the one hand, and early retirement on the other, though convincing at the group level, are too weak to permit individual predictions. Resignation is the only category with sufficient numbers of female employees to permit analysis. As could be expected, resignation is most prevalent in employees under thirty years. Convincing individual predictors of resignation could not be found, but the aggregated data show reasonable group differences the resignation group generally has more problems with work or health than the non-resignation group. These outcomes hold for the long as well as for the short form of the QWH questionnaire. In conclusion: though only disability can be predicted succesfully in the individual case, the outcomes on voluntary early retirement and resignation show enough differences at the group level to strengthen the predictive validity of the $Q W H$.

A discussion of the results centers around disability. The relevant literature describes two competing hypotheses. The popular attrition hypothesis (a) says that physically hard work results in wear, and this in turn to dropout because of disability. The deterioration hypothesis (b) maintains that if the person cannot sufficiently recover from work strain (be it physical or mental), this will, in the long run, degrade his working power, until he/she drops out of the workforce. The data prove that employees in production departments do not show more disability than those in non-production departments and that disability is just as frequent in managerial as in non-managerial jobs. The attrition hypothesis (a), therefore, is not plausible; the deterioration hypothesis (b), however, does square with the data.

On the strength of the results, recommendations are given concerning methods of turnover research, monitoring employees' health, and future research, the major recommendations being the following. A methodological recommendation is not to rely too much on separate questionnaire items, but to summarize the items in composite scores with better generalizability. Besides, arguments are given for longitudinal dropout studies over longer periods of time, using absenteeism data as well as workers" opinions (QWH-questionnaire data) as predictors. The recommendations on monitoring emplovees" health emphasize tracking their complaints on health, work strain and lllness behaviour, as well as their absenteeism (time 
lost) over the years. Increases in these time series signal employees in need of job modification in order to prevent disability. Reasons are given to treat voluntary early retirement and disability as interdependent phenomena. Attention is asked for employees who continue to work although they are entitled to early retirement, since this group probably refrains from retiring because of low expected income, in spite of possible health problems. In future studies, more attention should be given to the role of expected income in voluntary early retirement, to the evaluation of resignation for the employee and the employer, and to dropout of female employees. 
तै 8 क

\&

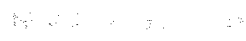

$8+\cdots$

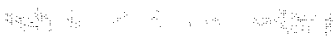

\%

$\therefore \quad \cdots$ 
AAF/AOF

AAW

ABP

$A B P W$

APO

BGD

$\mathrm{CAO}$

CBS

$\mathrm{CCOZ}$

df

EEG

FNV

GAB

GAK

GMD

ICD

IDR

IOAW

NIPG

NVAB

NWW

OR

POF

$\mathrm{SVr}$

TNO

VAG

VAG-kort

$V \%$

VF

VUT

WAO

WHO

WVC

WW

WWV

N.B.
Algemeen Arbeidsongeschiktheidsfonds/Arbeidsongeschiktheidsfonds

A'gemene Arbeidsongeschik theidswet

Algemeen Burgerlijk Pensioenfonds

Algemene Burgerlijke Pensioenwet

Algemeen Periodiek Onderzoek

Bedrijfsgezondheidsdienst

Collectieve Arbeidsovereenkomst

Centraal Bureau voor de Statistiek

Commissie Coördinatie Onderzoek Ziekteverzuim

degrees of freedom, vrijheidsgraden

Europese Economische Gemeenschap

Federatie Nederlandse Vakbeweging

Gewestelijk Arbeidsbureau

Gemeenschappelijk Administratiekantoor

Gemeenschappelijke Medische Dienst

International Classification of Diseases

Incidentiedichtheidsratio

Inkomstenvoorziening voor Oudere en gedeeltelijk Arbeidsongeschikte Werknemers

Nederlands Instituut voor Praeventieve Gezondheidszorg

Nederlandse Vereniging voor Arbeids- en Bedrijfsgeneeskunde

Nieuwe Werkloosheidlswet

ondernemingsraad

Periodiek Onderzoek Functioneren

Sociale Verzekeringsraad

Toegepast Natuurwetenschappelijk Onderzoek

Vragenlijst Arbeid en Gezondheid

idem, korte versie

verzuimpercentage

verzuimfrequentie

vervroegd uittreden

Wet op de Arbeidsongeschiktheid

World Health Organisation

Welzijn, Volksgezondheid en Cultuur

Werkloosheidswet

Wet Werkloosheidsvoorzieningen

In de tekst wordt soms 'werknemer' en 'hij" gebruikt, ongeacht of het om mannelijke of vrouwelijke werknemers gaat. 
४⿻ 


\subsection{Achtergrond en doelstelling}

Arbeidsongeschiktheid en ziekteverzuim zijn actuele maatschappelijke problemen; de noodzaak van een preventief beleid daarbij wordt algemeen erkend (Stichting van de Arbeid, 1989, 1990; Breed Overleg Arbeidsongeschiktheid, 1989; CNV, 1990; FNV, 1990; Ministerie van WVC, 1986, 1989; Tripartiete Werkgroep, 1989; VNO, 1990; Willems, 1989). In de onderhavige studlie wordt een onderzoek op dit terrein beschreven dat de relatie tussen arbeid en gezondheid, verzuim en vertrek uit het arbeidzame leven behandelt, met als doel het nagaan van de mogelijkheden om ongewenste uitval uit het werk te voorkomen. Onder 'ongewenste uitval' wordt hier in de eerste plaats arbeidsongeschiktheid verstaan; de twee andere vormen van uitval die beschouwd zullen worden zijn vervroegd uittreden (VUT) en ontslagname. Hoe ongewenst de beide laatste zijn is niet bij voorbaat duidelijk; het is algemeen bekend dat de VUT een populaire regeling is waarvan veel gebruik gemaakt wordt en verder kan ontslagname bij jonge werknemers als een normaal verschijnsel worden beschouwd, dat bij de vroege carrière hoort en de aanpassing tussen persoon en werk dient. Of VUT en ontslagname ongunstig (en dus te vermijden) zijn, zal daarom ook van de onderzoeksresultaten afhangen.

Dit onderzoek betreft ruim vijfduizend werknemers in vier bedrijven, die gedurende meerdere jaren gevolgd werden. Hun meningen over hun eigen gezondheid, werk en werkomstandigheden werden in het begin van die periode gepeild met de door het Nederlands Instituut voor Praeventieve Gezondheidszorg TNO ontwikkelde Vragenlijst Arbeid en Gezondheid (VAG, zie Dijkstra e.a., 1981, 1983). In de jaren daarna werden het ziekteverzuim en het eventuele vertrek uit het werk van deze werknemers vastgelegd. Verderop (hoofdstuk 4 en 5) wordt gezocht naar voorlopers van het vertrek van werknemers in deze ziekteverzuimen VAG-gegevens, met het oog op voorspelling en preventie van vertrek uit het werk.

Het onderhavige onderzoek naar voorspelbaarheid van uitval uit het werk staat uiteraard niet op zichzelf. Het heeft twee onderzoekslijnen tot achtergrond, na- 
melijk het periodiek onderzoek door de bedrijfsgezondheidszorg en het onderzoek naar de achtergronden van ziekteverzuim. Beide kanten worden hieronder geschetst.

In het te beschrijwen onderzoek wordt gebruik gemaakt van de Vragenlijst Arbeid en Gezondheid (VAG). De voorgeschiedenis van de VAG is in het kort de volgende (Dijkstra e.a., 1981). Tot na de tweede wereldoorlog werd binnen de arbeids- en bedrijfsgeneeskunde het periodiek onderzoek opgevat als het opsporen van ziekten in bedrijfspopulaties (Algemeen Periodiek Onderzoek, APO). Pas in de jaren vijftig (Beyerinck, 1957) werden bezwaren aangevoerd tegen dit type onderzoek. De belangrijkste bezwaren waren, dat de opbrengst aan nieuwe ziektegevallen laag is en met herhaald APO zelfs nog daalt, en dat het APO ethische problemen kan meebrengen (de werknemer zou een vals gevoel van veiligheid gegeven kunnen worden, de werknemer die zojuist 'gezond verklaard' is kan ertoe neilgen bij klachten zijn huisarts niet te raadplegen). Als alternatief voor het APO werd gezien onderzoek naar de wederzijdse aanpassing van werk en werknemer.

In 1971 werd dit alternatief uitgewerkt door de Nederlandse Vereniging voor Arbeids- en Bedrijfsgeneeskunde (NVAB, 1971): APO is slechts een randactiviteit van de bedrijfsarts; veel belangrijker is het samen met andere disciplines vormgeven aan de arbeid, zó dat gezondheidsproblemen worden voorkomen. Voor dit laatste is onder meer vereist dat men systematisch en periodiek gegevens verzamelt over de gezondheid en de werksituatie van werknemers door middel van het Periodiek Onderzoek naar het Functioneren van werknemers (POF). Dit standpunt bracht de NVAB in 1973 ertoe, het NIPG/TNO te vragen, een procedure voor POF te ontwikkellen. Dit leidde tot een project waarin, met als uitgangspunt de betreffende literatuur, stapsgewijs in bedrijfssituaties een procedure voor dit periodiek onderzoek ontwikkeld werd (Dijkstra e.a., 1981). Een belangrijk onderdeel van deze procedure is de Vragenlijst Arbeid en Gezondheid (VAG) die al eerder ter sprake kwam. Deze peilt naar de mening van de werknemer over diens eigen gezondheid, werk en werkomstandigheden. De VAG en zijn eigenschappen worden in dit proefschrift uitgebreid beschreven in hoofdstuk 3. 
Het tweede aspect van de achtergrond voor het huidige onderzoek is het ziekteverzuimonderzoek. Sinds 1947 behoort onderzoek naar het ziekteverzuim tot het werkterrein van het NIPG; aanvankelijk werd alleen verzuim in bedrijven geregistreerd en gepubliceerd, maar al snel kwam er ook aandacht voor de analyse van de cijfers en de verklaring van het verzuim. De benadering betrof in het begin vooral de medische kant; na verloop van tijd werd echter duidelijk dat begrip van de arbeidssituatie een eerste vereiste was voor het verklaren van het ziekteverzuim (De Groot, 1954; Ekker, 1962).

Er ontstond zodoende aandacht voor administratieve, economische en psychologische, dus niet-medische factoren. Het accent in het onderzoek verschoof daarmee van de medische naar de situationele factoren en de voornaamste vragen werden, voor welk deel van het verzuim de werksituatie in brede zin (van de concrete werkplek tot de macrosociale en -economische verhoudingen) aansprakelijk is en hoe de werknemer tot zijn beslissing om te gaan verzuimen komt (zie De Groot, 1955; Philipsen, 1962, 1969 Gadourek, 1965; Dijkstra, 1977). Inmiddels was voldoende bekend over de oorzaken van het ziekteverzuim om publiekelijk te demonstreren, dat in elk bedrijf rationele acties kunnen worden ondernomen om het verzuim te beheersen. Hiertoe werd het 'Actieprogramma Ziekteverzuim' ondernomen (Draaisma e.a., 1976). Verder werd een overzicht van de praktische mogelijkheden tot beheersen van het verzuim gegeven in Draaisma \& Smulders (1978). Hierin werden de bereikte inzichten geïntegreerd in een actiecyclus ten behoeve van het bedrijf, lopend van de registratie van het verzuim, via het signaleren van hoog verzuim en het vaststellen van de beïnvloedende factoren, tot het treffen en het evalueren van verzuimbeperkende maatregelen.

Het werk in het NIPG op het terrein van het ziekteverzuim is in de jaren ' 80 voortgezet met onder meer de publicaties van Draaisma (1983) en Smulders (1984a, b). De studie van Draaisma richtte zich op verzuimfactoren buiten het bedrijf, met name de verzekeringsvorm in de Ziektewet, omdat over zulke factoren boven het bedrijfsniveau betrekkelijk weinig bekend was. Hij concludeerde dat bij grotere bedrijven verlaging van WAO-risico en ziekteverzuim mogelijk was door de werkgever meer eigen risico te laten dragen en de Ziektewetcontrole meer in handen van het bedrijf te leggen. Smulders (1984a) woerde een replicatie uit van het onderzoek van Philipsen (1969); hij ging van dezelfde orga- 
nisatiekenmerken in een vergelijkbare steekproef van bedrijven $n a_{\text {, wat }}$ we samenhang van die kenmerken met het ziekteverzuim is. De structuur van de organisatiekenmerken en hun samenhang met het ziekteverzuim bleken in grote trekken dezelfde gebleven te zijn. Wel bleken er in het bedrijfsleven veranderingen te zijn opgetreden in vergelijking met de jaren zestig: steilere organisaties, meer ploegenarbeid, in het allgemeen toch hogere kwaliteit van de arbeid, en een meer professionele personeelsfunctie.

Het huidige onderzoek staat in beide hierboven beschreven tradities; het is een toepassing van de VAG die mede gebaseerd is op het ziekteverzuim. Wat de VAG betreft gaat het om het vaststellen van de praktische en theoretische betekenis (zie paragraaf 1.2 ), niet om een verdere ontwikkeling van het bestaande instrument; om die reden zijn er geen vragen gewijzijgd, weggelaten of toegevoegd. Een verschil met het beschreven ziekteverzuimonderzoek is, dat bij het beschreven eerdere onderzoek van het NIPG het verzuim verklaard wordt met het oog op de beheersing ervan, maar dat hier het verzuim, naast de vragenlijstgegevens van de VAG, gebruikt wordt als grondslag om latere uitval uit het werk te voorspellen en deze zo mogelijk te beperken.

Er kunnen drie niveaus van preventie worden onderscheiden: primaire preventie (voorkömen dat gezondheidsproblemen optreden), secundaire preventie (verhinderen dat die problemen verergeren) en tertiaire preventie (het verzachten van de gevolgen van gezondheidsproblemen). De gedachte achter thet te beschrijven onderzoek is dat later vertrek uit de werksituatie misschien samenhangt met vermijdbare problemen in arbeid en gezondheid in een eerder stadium (opgespoord met de VAG d.w.z. werknemersmeningen en met verzuimgegevens). Als die problemen vroeg gesignaleerd kunnen worden, kunnen er bijtijds correcties in de werksituatie aangebracht worden die onnodige uitval van werknemers voorkómen. Deze studie exploreert dus de mogelijkheden van primaire preventie. Daarbij kan gedacht worden aan verschillende typen interventie zoals wijziging van de arbeidsinhoud, -methoden of -omstandigheden, hulp, scholing en training voor de werknemer (zie Broekhuis, 1986; Den Heeten e.a., 1987, Dul \& Pasmooij, 1985; Funke e.a., 1988 ; Kuiper, 1983; Poll, 1983; Quick \& Quick, 1984; Tappèl \& Terra, 1986). 
Mogelijkheden tot interventie zijn er genoeg, de opgave is alleen, na te gaan of verzuim en werknemersmeningen ons in staat stellen, vroeg te bepalen welke werknemers er in een gegeven arbeidssituatie in moeilijkheden dreigen te komen en welke niet. Voor zover dit slaagt kunnen er aanbevelingen worden gedaan voor screening op uitval uit het werk en weten we bovendien wat de voorspellende validiteit van de vragenlijstgegevens (de VAG) is; dit zijn twee kanten van dezelfde zaak, namelijk de geldigheid van de voorspellingen met de VAG. Er is dus sprake van een tweevoudige doelstelling: 1) nagaan van de voorspelbaarheid van het individuele vertrek uit het werk op basis van gegevens over arbeid, gezondheid en verzuim met het oog op de preventie van ongewenste uitvall en 2) validatie van de NIPG-Vragenlijst Arbeid en Gezondheid (VAG).

1.2 Verklarende en te verklaren variabelen, vraagstelling

\subsubsection{Verklarende en te verklaren variabelen}

Hiervoor werd het belangrijkste materiaal voor het onderzoek all in het voorbijgaan genoemd: uit vier bedrijven afkomstige verzuimgegevens, werknemersmeningen (antwoorden op de Vragenlijst Arbeid en Gezondheid, VAG) en over meerdere jaren verzamelde gegevens over het vertrek van werknemers; alles op individueel niveau. De verzuimgegevens en de VAG leveren de verklarende variabelen; de vertrekgegevens zijn de te verklaren variabelen. In hoofdstuk 3 wordt in detail op de variabelen en hun eigenschappen ingegaan; hieronder wordt voor een goed begrip kort uiteengezet wat de aard van deze variabelen is, welke verbanden er globaal verwacht worden en wat de vraagstelling van het onderzoek is.

Voor de verzuimgegevens geldt het volgende (zie ook paragraaf 3.5 ). In elk bedrijf werden de ziekteverzuimgegevens van de werknemers per kalenderjaar verzameld in de vorm van de duren van de achtereenvolgende verzuimgevallen per werknemer. Uit deze gegevens werden per werknemer voor elk jaar twee variabelen samengesteld, namelijk de verzuimfrequentie en het verzuimpercentage. De verzuimfrequentie geeft aan, hoeveel verzuimgevallen er in het be- 
schouwde jaar eindigden en het verzuimpercentage geeft aan, welk deel van de werkdagen aan ziekteverzuim verloren ging (gerekend over dezelfde verzuimgevallen).

De VAG kent een lange versie met 117 vragen en een korte versie met 40 vragen, zoals uiteengezet wordt in paragraaf 3.3. Beide versies leveren scores per onderwerp op die hoger zijn, naarmate er meer problemen leven bij de werknemer. De lange versie telt zeven onderwerpen, nl. Inspanning, Gezondheid, Ziektegedrag, Materiële Werkomstandigheden, Taak en Werkorganisatie, Leiding en Collega's en Waardering voor de Werkkring. Bovendien worden de meningen samengenomen tot drie brede scores. $n$ l. Conditie (een samenvatting van Inspanning $\mathrm{t} / \mathrm{m}$ Ziektegedrag) en Werksituatie ${ }_{\iota}$ (id. Materiële Werkomstandigheden $\mathrm{t} / \mathrm{m}$ Waardering Werkkring) en een totaalscore. De korte VAG is verdeeld in drie scores, nl. Conditie $k_{k}$ en Werksituatie $_{k}$ (parallel aan de lange versie) en een eigen totaalscore.

Het volgende geldt wat betreft de te verklaren variabelen. Een werknemer kan vanzelfsprekend op verschillende manieren van zijn werkplek vertrekken: door bevordering of overplaatsing, door ontslag te krijgen of te nemen, door arbeidsongeschiktheid, (in het laatste geval soms door herplaatsing in ander werk), door overlijden, vervroegd uittreden of door ouderdomspensioen. De uitval uit het werk die bestudeerd zal worden, kent drie vormen: arbeidsongeschiktheid, vervroegd uittreden (VUT) en ontslagname. De grond voor deze keuze is (zie paragraaf 1.1), dat zeker de arbeidsongeschiktheid en misschien VUT en ontslagname ongewenst zijn, terwijl het niet onaannemelijk is, dat deze vertrekwijzen zich al vroeg aankondigen in problemen van de werknemer met zijn werk en werksituatie en in een toename van het ziekteverzuim.

Het vertrek uit het werk is sterk leeftijdsgebonden, zoals ook uit de literatuur (hoofdstuk 2) blijkt. Ontslagname vindt vroeg in het arbeidzame leven plaats, vör 30 of 40 jaar; arbeidsongeschiktheid treedt later op, vaak tegen de vijftig jaar, en vervroegd uittredien is gebonden aan een formele VUT-leeftijd van rond de zestig jaar. Gegeven deze leeftijdsverschillen naar wijze van uittreden, valt niet anders te verwachten dan dat bij voorspelling uit tegelijk werknemersmeningen, veruimgegevens en leeftijd, de variabele "leeftijd" de beide andere zou 
overheersen. De onderzoekswraag is niet, in hoeverre vertrek uit het arbeidzame leven leeftijdsafhankelijk is (niemand zal dit bestrijden, zie hierboven) maar wat, gegeven de leeftijd van werknemers, de voorspellers van vertrek zijn. Om dit te bereiken heeft de variabele 'leeftijd' de rol van stratificatievariabele in het onderzoek gekregen; de werknemers $z i j$ in ingedeeld in passende leeftijdsgroepen en er wordt naar voorspellers van vertrek gezocht binnen elke leeftijdsgroep.

Wat valt er, enigszins realistisch gezien, aan onderzoekresultaten te verwachten? Zoals er al van tevoren globale verwachtingen ten aanzien van de rol van de leeftijd kunnen worden geformuleerd, kunnen er ook globale verwachtingen over de aard van de te verwachten verbanden worden uitgesproken. Wat betreft de afzonderlijke vertrekwijzen zijn deze globale verwachtingen de volgende.

Arbeidsongeschiktheid wordt uitgesproken op grond van een medisch onderzoek; in de mate van arbeidsongeschiktheid speelt de beoordeelde gezondheid een belangrijke rol. Soms (ongevallen, acuut optredende aandoeningen) treedt de arbeidsongeschiktheid van het ene moment op het andere op; in andere gevallen ontwikkelt de arbeidsongeschiktheid zich geleidelijk. In dat laatste geval ligt het voor de hand diat gezondheidsklachten, problemen in het functioneren op de werkplek (beide gemeten met de VAG, zile eerder) en het ziekteverzuim alle drie toenemen in de tijd. Globaal valt: daarom te verwachten, dat er een zekere samenhang tussen enerzijis de VAG en de ziekteverzuimgegevens en anderzijds de arbeidsongeschiktheid zou kunnen zijn.

Vervroegd uittreden (zie paragraaf 2.3 ) kan met de gezondheid en met problemen in het werk te maken hebben, mar dit is niet zo duidelijk als bij arbeidsongeschiktheid. De beslissing, al of niet gebruik te maken wan de VUT zou misschien meer met het later verwachte inkomen kumnen samenhangen dan met de huidige gezondheid en arbeid. Bovendien is de VUTregeling aan verandering onderhevig, want de VUT-leeftijd is in de loop van de jaren gedaald, de toeloop is groot, maar de demografische ontwikkeling (vergrijzing) maakt dat de VUT-regelingen vermoedelijk niet in hun actuele vorm te handhaven zijn. Er valt hier te conoluderen dat het vervroegd uittreden als verschijnsel in een fluide toestand werkeert en dat het daarom riskant is, teveel verwachtingen t.a.v. de VUT te formuleren. Dit 
proefschrift is daarom terughoudend met verwachtingen betreffende de voorspelbaarheid van de VUT.

- Ontslagname komt hoofdzakelijk voor in de groep relatief jeugdige werknemers en is daar deel van aanpassingsgedrag en een normaal verschijnsel (paragraaf $1.1,2.4$ ). In de eerste plaats is daarom niet van tevoren duidelijk, of ontslagname gewenst dain wel ongewenst is en evenmin of ontslagname voorkómen zou moeten worden. Verder is a priori gegeven dat er bij de ontslagname ook andere factoren dan de gezondheid en het functioneren in het huidige werk mee kunnen spelen: de aantrekkelijkheid van ander werk, een andere werkgever, een andere plaats; een kans op positieverbetering die zich plotseling voordoet; vrouwelijke werknemers houden bovendien soms op met betaald werk vanwege huwelijk of geboorte van kinderen.

Los van de wijze van vertrekken geldt overal dat de VAG niet ontworpen is om toekomstig vertrek uit het arbeidzame leven te voorspellen, maar om problemen in werk en gezondheid vast te stellen. Hoewel aannemelijk is, dat sommig vertrek uit het werk met problemen kan samenhangen die gemeten kunnen worden met de VAG, bestaat er geen garantie dat VAG-scores voorspellende waarde zullen hebben voor vertrek uit het werk. Er zijn dus op voorhand al uiteenlopende redenen om geen sterke voorspellingen van vertrek uit het werk te verwachten in thet onderzoek. Zou de VAG enige waarde blijken te hebben voor de voorspelling op individueel niveau van een of meer vertrekwijzen, dan is dat bij wijze van spreken zuivere winst.

\subsubsection{Vraagstelling}

De vraagstelling is tweeledig, zoals al aangestipt werd in paragraaf 1.॥:

- primair is de vraag, of er determinanten van vertrek uit het werk (arbeidsongeschiktheid, VUT of ontslagname) te vinden zijn binnen de verklarende variabelen (ziekteverzuim- en VAG-gegevens), die voorspelling en daarmee beïnvloeding van individueel vertrek mogelijk maken, het accent ligt daarbij (zie eerder) op de voorspelling van arbeidsongeschiktheid;

- methodologisch is de vraag naar de validiteit van het gebruikte instrument, namelijk de VAG, de Vragenlijst Arbeid en Gezondheid. 
De twee delen van de vraagstelling zijn twee aspecten van hetzelfde, namelijk de kracht van de voorspelling d.w.z. het praktische aspect (kan onnodig vertrek uit het werk worden voorspeld en voorkomen?) en het wetenschappelijke aspect (wat is de predictieve validiteit van de VAG?). Deze twee aspecten zijn conceptueel verschillend, maar empirisch zo verweven, dat kennis van het ene aspect samenvalt met kennis van het andere. Daarom komt de predictieve validiteit van de VAG aan de orde in de resultatenhoofdstukken 4 en 5 (lange versie van de VAG paragraaf $4.1 .5,4.2 .5$ en 4.3 .5 ; korte VAG 5.1.4, 5.2.4 en 5.3.4). De nietpredictieve validiteitsaspecten van de VAG worden afzonderlijk behandeld in hoofdstuk 3 (lange VAG paragraaf 3.6, korte VAG 3.7).

\subsection{Methode: prospectief epidemiologisch onderzoek}

Om de eerste vraag te beantwoorden gaan we ervan uit dat het vertrek uit het werk zich niet van het ene op het andere moment voordoet, maar dat het een voorgeschiedenis heeft. Bij arbeidsongeschiktheid, vervroegd uittreden en ontslagname is in te denken, dat de werknemer steeds meer problemen in het werk heeft, totdat de situatie onhoudbaar wordt en de werknemer via WAO, invaliditeitspensioen of VUT of ontslagname vertrekt. Wat betreft de WAO is dit door Lenshoek e.a. (1989) op groepsniveau aangetoond: er zijn risicogroepen waarin de WAO zich lang tevoren aankondigt in langdurige ziekte. Kompier e.a. (1990) laat zien dat bij stadsbuschauffeurs (verzekerd bij het $\mathrm{ABP}$ ) de arbeidsongeschiktheid door een periode van toenemend verzuim wordt voorafgegaan. Bij vervroegd uittreden is in te denken, dat de aantrekkelijkheid van niet-werken ten opzichte van werken bij sommige werknemers toeneemt en bij andere niet. Men kan zich bij ontslagname, naast wat in paragraaf 1.2 genoemd werd, voorstellen dat sommige werknemers een tegenzin tegen hun werk ontwikkelen, die uiteindelijk tot de ontslagname leidt. Over zulke voorgeschiedenissen is (zie hoofdstuk 2) weinig bekend. Om vast te stellen of ze bestaan (en dus of de mogelijkheid tot predictie en preventie aanwezig is) moet daarom onderzoek gedaan worden. Om het traject voor het vertrek in kaart te brengen dient het onderzoek werknemers in de tijd te volgen, in technische termen is er een longitudinaal onderzoeksdesign vereist. 
In het kort is het onderzoek als volgt verlopen. In vier bedrijven werden in principe alle werknemers met de VAG geënquêteerd. Dit gebeurde in een bedrijfsonderzoek met als oorspronkelijk doel alleen, het bedrijf te informeren over het functioneren van de werknemers. De toenmallige uitkomsten zijn echter met toestemming van de betrokken bedrijven en personeelsvertegenwoordigingen bewaard en over een aantal jaren aangevuld met gegevens over het ziekteverzuim en het latere vertrek van de werknemers.

Er zijn vertrekwijzen die om verschillende redenen buiten beschouwing zullen blijven, nl. bevordering en overplaatsing, gedwongen ontslag, overlijden, herplaatsing bij blijvende gedeeltelijke arbeidsgeschiktheid (hierna kortweg 'herplaatsing') en ouderdomspensioen. Bevordering en overplaatsing kunnen worden gezien als normale gebeurtenissen in een arbeidscarrière die niet ongewenst zijn, en die daarom buiten het onderwerp van deze studie vallen. Het aantal overlijdensgevallen in het materiaal is gering en moet om die reden buiten beschouwing gelaten worden. Wat betreft herplaatsing: deze werknemers moeten eerst voor een deel arbeidsongeschikt verklaard zijn, voor zij herplaatst werden. Daarom vallen zij hier onder het onderwerp 'arbeidsongeschiktheid". De laatste niet-beschouwde vertrekwijze is het ouderdomspensioen; de reden is, dat dit slechts een restcategorie vormt van werknemers die niet op andiere wijze uit het werk verdwenen en die de vastgestelde pensioenleeftijd bereikten.

In termen van Kessler en Greenberg (1981) is het huidige onderzoek een 'catchup panel study'; het is echter duidelijker te spreken van een prospectieve epidemiologische cohort-studie van uitval uit het werk (Sturmans en Valkenburg, 1977; Sturmans, 1984; Rothman, 1986; Bouter \& Van Dongen, 1988). Binnen de epidemiologie hoeft het namelijk niet over specifieke aandoeningen te gaan, maar kan ook heel goed de algemene vatbaarheid voor ziekten worden bestudeerd (Syme \& Berkman, 1976). Zo ook in dit geval waar de vatbaarheid voor ziekten vertaald is in de kans op arbeidsongeschiktheid, VUT en ontslagname. 


\subsubsection{Relevantie van het onderzoek in cijfers}

Tabel 1.1 geeft cijfers over de periode vanaf 1970 , een periode van twintig jaar. Om de vertrekcijfers meer reliêf te geven zijn de omvang van de gehele- en de beroepsbevolking vermeld. Daarbij zijn tot 1980 de stappen telkens vijf jaar en daarna één jaar omdat de meest recente jaren het interessantst zijn.

Het onderhavige onderzoek behandelt als vertrekwijzen arbeidsongeschiktheid, vervroegd uittreden en ontslagname. In tabel 1.1 is de arbeidsongeschiktheid volgens drie regelingen weergegeven (zie ook paragraaf 2.2.1), nl. de Algemene Arbeidsongeschiktheidswet (AAW), de Wet op de Arbeidsongeschiktheid (WAO) en het invaliditeitspensioen van de Algemene Burgerlijke Pensioenwet. Deze wetten betreffen respectievelijk alle ingezetenen van Nederland, degenen die in loondienst zijn en de ambtenaren. Tenslotte de VUT-cijfers; de regelingen voor vervroegd uittreden zijn verschillend bij particuliere bedrijven, trendvolgers en overheid. Om de trend goed te laten uitkomen, is hier de grootste groep, nl. de bedrijven genomen; de cijfers van de verschillende groepen werknemers worden gegeven in paragraaf 2.3 .2 .

Over de aantallen ontslagnamen werden geen gegevens gevonden. Het CBS (mondelinge opgave, 1987) kent well aantallen aanvragen door werkgevers van ontslagvergunningen door de Gewestelijke Arbeidsbureaus, maar deze vormen duidelijk niet het gewenste gegeven. Verder zijn er de Arbeidskrachtentellingen (bijv. CBS, 1982a). Hierin worden de werklozen en werkzoekenden gespecif $\mathrm{i}$ ceerd naar (onder meer) de reden van beëindiging van de laatste werkkring. Ons onderzoek heeft geen betrekking op werklozen, zodat de werkzoekenden van de Arbeidskrachtentelling geen goed beeld vormen van de ontslagnamen waar het in dit onderzoek om gaat. Over ontslagname kunnen daarom geen cijfers worden vermeld." 
Iabel 1.1 statistische gegevens over bevolking en vertrek ult het werk de periode 19701990 in Hederland (duizendtal len)

\begin{tabular}{|c|c|c|c|c|c|c|c|}
\hline \multirow[b]{2}{*}{ joar } & \multirow{2}{*}{$\begin{array}{l}\text { bevol - } \\
\text { king }\end{array}$} & \multirow[t]{2}{*}{ 1) } & \multirow{2}{*}{$\begin{array}{l}\text { beroeps- } 1,2) \\
\text { bevolking }\end{array}$} & \multicolumn{3}{|c|}{ arbeidsongleschiktheid } & \multirow[b]{2}{*}{ WUT ${ }^{5}$} \\
\hline & & & & AAW 3 3) & waO 3 ) & $A B P 4$ & \\
\hline 1970 & 12958 & $\cdots$ & 4737 & $\cdots$ & 196 & 17 & $\cdots$ \\
\hline 1975 & 13599 & & 4991 & $\ldots$ & 312 & 32 & -. \\
\hline 1980 & 14091 & $\therefore$ & 5416 & 165 & 440 & 53 & $\$ 1$ \\
\hline 1981 & 14209 & & 5547 & 175 & 455 & 57 & 12 \\
\hline 1982 & 14286 & & 5694 & 182 & 463 & 62 & 14 \\
\hline 1983 & 14340 & & 5810 & 186 & 474 & 67 & 16 \\
\hline 1984 & 14395 & & 5860 & 195 & 485 & 70 & 20 \\
\hline 1985 & 14.454 & & 5920 & 205 & 490 & 71 & 21 \\
\hline 1986 & 14529 & & 5973 & 214 & 494 & 71 & 24 \\
\hline 1987 & 14615 & & 6013 & 214 & 507 & 73 & 30 \\
\hline 1988 & 14688 & & 6235 & 220 & 509 & 74 & 35 \\
\hline 1989 & 14801 & & 6345 & 230 & 494 & 76 & 39 \\
\hline 1990 & 14867 & & 6448 & 234 & 465 & $\cdots$ & 43 \\
\hline
\end{tabular}

1) $\cos (4988 a, b ; 1989)$

2) $\mathrm{CBS}$ ( $1981,1985,1987)$; op de Beke, 1987

3) Minister wan Sacialle Zaken en Werkgelegenheid (1988); uitkeringsjaren

4) aantallen inval iditeitspensioenen van personen $<65$ jaar, opgave $A B P$

5) Ministerle van Saclalle Zaken en Werkgelegenheid (1988); wUT-deelnemers bedrijven

De Financiële Nota Sociale Zekerheid 1989 (Ministerie van Sociale Zaken en Werkgelegenheid, 1988) schat dat bij ongewijzigd beleid het aantal arbeidsongeschikten in het jaar 2010 circa 1.130 .000 zal zijn. Rekening houdend met de afschaffing van de verdiscontering en de invoering van de IOAW (zie paragraaf 2.2.1) zal dat volgens dezelfde bron in 2010 op ruim een miljoen arbeidsongeschikten uitkomen.

Het aantal vervroegd uitgetredenen (VUT, meest rechtse kolom) is na een aarzelend begin in 1980 explosief gegroeid. In de loop van tien jaar is het gestegen tot drieènveertigduizend, wat een bewijs zou kunnen inhouden voor de populariteit van deze regeling. De aantallen VUT-ters volgens het Centraal Planbureau zijn niet in tabel 1.1, maar in tabel 2.5 (paragraaf 2.3.2) aangegeven; hoewel de aantallen niet overeenkomen, is ook daar sprake van een stormachtige groei.

De gegevens van tabel 1.1 laten verder in grote trekken het volgende zien. De bevolking en ook de beroepsbevolking vertonen een langzame maar gestage groei. 
Ook alle drie de arbeidsongeschiktheidsregelingen (AA, WAO en invaliditeitspensioen van de ambtenaren) laten toenamen zien. Deze zijn echter veel sterker (vooral bij WAO en ABP) dan de groei van de beroepsbevolking. Of de ontwikkeling in de VUT wenselijk is dan wel onwenselijk, valt op grond van de cijfers alleen niet te zeggen (hierop wordt nader ingegaan in paragraaf 2.3.3). Het is echter well duidelijk dat de ontwikkeling in de groei van de arbeidsongeschiktheid bestreden moet worden omdat deze hoge kosten voor werknemer en samenleving meebrengt. Het hier te beschrijven onderzoek wil daaraan bijdragen (zie paragraaf 1.1) door voor de individuele werknemer vroege signalen op te sporen die diens uitval kunnen helpen voorkómen.

\subsubsection{Relevantie van het onderzoek voor de bedrijfsgezondheidszorg}

De drie reeksen arbeidsongeschiktheidscijfers van tabel 1.1 tonen stijgingen die in de jaren ' 80 afvlakken en dan een plateau te zien geven. Wat betreft de ambtenaren in het ABP meent Thijssen (1990) dat dit plateau samenhangt met een toename van de VUT. Veel oudere ambtenaren zouden indertijd, als er geen VUT geweest was, een invaliditeitspensioen gekregen hebben. Thijssen voorspelt daarom dat toekomstige bezuinigingen in de VUT voor ambtenaren tot een toename van de aantallen arbeidsongeschikten in het ABP zullen leiden.

Van drie reeksen arbeidsongeschiktheidscijfers in tabel 1.1 geeft ook de WAO na een aanvankelijk sterke stijging een afname in de groei te zien en de laatste jaren zelfs een plateau. Er is hier blijkbaar een evenwicht tussen nieuwe en beeindigde gevallen bereikt, een conclusie die eerder al door Bijlsma en Koopmans (1984) getrokken is. Bij dit evenwicht is het aantal arbeidsongeschikten in de WAO echter nog steeds hoog (meer dan een miljoen uitkeringen voor ongeveer driekwart miljoen personen); en AAW en ABP laten slechts stijgingen zien.

Vermoedelijk zal de reïtegratie van WAO-gerechtigden wel een aanzienlijke besparing op de uitkeringsgelden tot gevolg kunnen hebben, maar het aantal personen dat een beroep doet op de WAO zal er nauwelijks door verminderen (Van der Stelt \& Bruinsma, 1989). Het is daarom gewenst, naast reintegratie/se- 
cundaire preventie te streven naar primaire preventie, het voorkómen dat werknemers ooit arbeidsongeschikt worden.

Onderzoek als het onderhavige, dat hieraan wil bijdragen, kan daarom van waarde zijn. Dit nog ervan afgezien, dat arbeidsongeschiktheid bij voorbaat ongewenst is voor de individuele werknemer en om die reden bestreden moet worden. Een dergelijk oordeel over de beide andere vertrekwijzen (VUT en ontslagname) is niet op voorhand mogelijk; er zal moeten blijken of deze vertrekwijzen te maken hebben met ongewenste of schadelijke aspecten van het werk.

De Arbeidsomstandighedenwet stelt de werkgever verantwoordelijk voor de inrichting van de arbeid, zo dat veiligheid, gezondheid en welzijn van de werknemer zo goed mogelijk gewaarborgd zijn (artikel 1, a en h). De werkgever moet zijn beleid daarop richten en dit regelmatig toetsen aan de ervaringen die ermee worden opgedaan (artikel 4, punt 1 en 2). De rol van de bedrijfsgezondheidsdienst komt aan de orde in artikel 18 (lid 3): de bevordering en de bescherming van de gezondheid van de werknemers, die moet worden gerealiseerd door adviezen van de bedrijfsgezondheidsdienst aan ondernemingsraad, werknemers en werkgever.

Het eerste doel van het huidige onderzoek, nl. het zoeken naar mogelijkheden om naderende ongewenste uitval uit het werk tijdig te signaleren en te voorkómen past niet alleen in de wettelijk voorgeschreven taak van de bedrijfsgezondheidszorg. Het sluit ook aan bij het in de Nota 2000 (Ministerie van WVC, 1986) aangeduide streven de preventie te bevorderen, en bij het Charta van Bedrijfsartsen in de EEG, dat spreekt van "het voorkómen van schadelijke invloeden door het beroep, alsmede het tijdig onderkennen van ziekten en aantastingen van de gezondheid door de arbeidsomstandigheden en te adviseren ter correctie van de situatie" (Permanent Comité van Artsen in de EEG, 1981). De Nederlandse Vereniging voor Arbeids- en Bedrijfsgeneeskunde (NVAB, 1987) stelt het in de Doelstellingen Beroepsopleiding als volgt: "Als taken kunnen worden genoemd o.a.: het opsporen en signaleren van die factoren in de arbeidssituatie die de gezondheid kunnen bedreigen..." (bladzijde 1) en "...de bedrijfsarts moet niet reactief zijn , maar juist ook actief vanuit een gerichte onderzoekende instelling, 
om zo zelf zaken op te sporen die hij/zij vanuit de eigen deskundigheid riskant acht" (bladzijde 4).

\subsubsection{Relevantie van het onderzoek voor het overheidsbeleid}

In de periode 1970 - 1990 liepen de uitkeringen van de sociale verzekeringen op van $f 17,5$ miljard tot $f 107,3$ miljard (van $15,7 \%$ tot $24,9 \%$ van het national inkomen). De arbeidsongeschiktheid (alleen WAO) was in die tijd rond $1.6 \%$ van het nationaal inkomen. Maar de AAW steeg van 0,2\% (1976) tot 2,6\% (1987). Om een indruk te geven van de geldbedragen, in 1987 werd voor de WAO $f 6.946$ miljoen en voor de AAW $f 11.143$ miljoen uitgekeerd (Ministerie van Sociale Zaken en werkgelegenheid, 1988).

De toename in de kosten van de sociale zekerheid is al langere tijd een reden voor de overheid om te trachten, de ontwikkelingen terug te dringen (De Graaf, 1982). De belangrijkste motieven hiervoor zijn de volgende:

- de omvang en de voortdurende groei van de problematiek;

- het beslag dat daardoor op een toenemend deel van het mationale inkomen wordt gelegd en

- de gebleken problemen bij het weer in het arbeidsbestel integreren van personen met resterende arbeidscapaciteit.

De overheid streeft daarom via het "volumebeleid" naar minder arbeidsongeschiktheid, een lager aantal uitkeringsgerechtigden, kortere uitkeringsduren en het vermijden van onnodige werkloosheid en verzuim. Zo zou (nog steeds De Graaf, 1982) de verhouding tussen collectieve- en marktsector verbeteren en zou de werkgelegenheid via een wijziging van het stelsel van de sociale zekerheid weer aantrekken.

Het volumebeleid is nader uitgewerkt in een recent kabinetsstandpunt (Ter Veld, 1990). Hierin wordt het belang van preventieve maatregelen ter beperking van het ziekteverzuim en van de toestroom naar de arbeidsongeschiktheidsregelingen op de voorgrond gesteld. Het doel van de preventieve activiteiten is drieledig:

- "bevorderen van de gezondheid van hen die werken, met name voorzover de gezondheid onder invloed staat van het werk en de werkomstandigheden; 
bevorderen van het gezond werken van arbeidsorganisaties: dit is nodig om het eerste doel te bereiken (...);

- voorkómen van onnodige arbeidsongeschiktheid van werkenden."

Het kabinet stelt, dat de verwerkelijking van deze doelstelling nog ver verwijderd is en dat de eerste opgave is, de preventieve activiteiten te bevorderen. Dit zou onder meer op de volgende wijze moeten gebeuren:

- "intensivering van het arbeidsomstandighedenbeleid van de overheid;

- uitbreiding van de dienstverlening van deskundige instellingen zoals bedrijfsgezondheidsdiensten en verbetering van de $k$ waliteit van de dienstverlening; ..." en

- "verbetering van de beleidsvoering door bedrijven op het gebied van de arbeidsomstandigheden en verzuimbeheersing".

Dit beleid dient in alle bedrijfstakken ondersteund te worden door dienstverlening van werkgevers- en werknemersorganisaties, waarbij de bedrijven financieel geprikkeld worden om preventief op te treden tegen ziekteverzuim en arbeidsongeschiktheid. Het is duidelijk dat het beleid gediend zou kunnen zijn met maatregelen, gebaseerd op resultaten van het onderhavige onderzoek, want dit laatste is gericht op het voorkómen van dreigende arbeidsongeschiktheid.

\subsection{De verdere hoofdstukken}

Hoofdstuk 2 geeft een overzicht van de literatuur. De achtergronden van arbeidsongeschiktheid, vervroegd uittreden en ontslagname worden geschetst en vastgesteld wordt, welke consequenties dit voor het onderhavige onderzoek heeft (paragraaf 2.5).

Hoofdstuk 3 geeft een uitgebreid overzicht van de gebruikte variabelen (verklarende, te verklaren en achtergrondvariabelen). Tevens wordt ingegaan op de betrouwbaarheid en de validiteit van deze gegevens. Aan het eind van hoofdstuk 3 wordt verantwoord welke statistisch-epidemiologische bewerkingen er uitgevoerd zijn om alle gewenste informatie uit het datamateriaal te halen. Aangezien vertrek geen continue variabele is, worden er epidemiologische technieken gebruikt die hierbij passen. 
In hoofdstuk 4 en 5 worden de resultaten van het onderzoek gepresenteerd. In deze twee hoofdstukken wordt nagegaan of de verklarende variabelen voorspellers zijn van het latere vertrek. Hoofdstuk 4 behandelt de lange versie van de VAG, hoofdstuk 5 de korte VAG; in beide hoofdstukken wordt verder als voorspeller het verzuim in het kalenderjaar voor het VAG-onderzoek gebruikt. Voor elke vertrekwijze wordt eerst berekend of er verschillen zijn tussen wel- en niet-vertrokkenen op elk van de verklarende variabelen. Op grond hiervan wordt beslist, welke variabelen er als voorspeller van elke vertrekwijze kunnen dienen en welke niet. Over de geselecteerde verklarende variabelen wordt vervolgens berekend, wat zij afzonderlijk en tezamen aan voorspellingen van vertrek mogelijk maken.

In hoofdstuk 6 wordt het onderzoek samengevat wat betreft achtereenvolgens arbeidsongeschiktheid, vervroegd uittreden en ontslagname en tot slot worden aanbevelingen geformuleerd die op de uitkomsten gebaseerd zijn. Die aanbevelingen betreffen methoden van onderzoek, voorspelling van uitval en verder onderzoek over uitval uit het werk. 


\section{$2.1 \quad$ Inleiding}

Het hier beschreven onderzoek heeft, zoals aangegeven in hoofdstuk 1 , een tweeledig doel: in de eerste plaats het ontwikkelen van voorspellingen van arbeidsongeschiktheid, vervroegd uittreden en ontslagname en in de tweede plaats het valideren van de Vragenlijst Arbeid en Gezondheid (VAG). Het onderzoek is dus vooral gericht op methode-ontwikkeling en niet op de toetsing van hypothesen die aan de literatuur over vertrek uit het arbeidsleven zijn ontleend. De relatie tussen literatuur en empirie is hier zwak doordat de gegevens niet verzameld werden met het oog op toetsing van hypothesen. Toch zou het onverstandig zijn, om die reden de betreffende literatuur buiten beschouwing te laten. In de eerste plaats geeft deze indicaties over de achtergrond van vertrekkende werknemers, nl. dat onder meer de arbeidsongeschikten relatief oude werknemers zijn en dat de ontslagnamen voor het grootste deel bij de jongere werknemers te vinden zijn. Verder geeft de literatuur suggesties over de te verwachten verbanden: problemen met de gezondheid zouden kenmerkend zijn voor arbeidsongeschiktheid en VUT, en problemen met allerlei aspecten van arbeid en gezondheid zouden samen gaan met ontslagname. De functie van de literatuur die hier vermeld wordt, is dus niet het leveren van te toetsen hypothesen, maar het leveren van de achtergrond voor de instrumentontwikkeling.

\subsection{Arbeidsongeschiktheid}

\subsubsection{Wettelijke arbeidsongeschiktheidsregelingen}

De Wet op de Arbeidsongeschiktheid (WAO) is in werking sinds 1967. De WAO heeft een drieledig doel, nl. het geven van bestaanszekerheid, reïntegratie van gehandicapten en gelijke maatschappelijk ontplooiïngskansen voor WAO-ers. Hiervan is alleen de cerste doelstelling ontwikkeld, maar daarbij zijn de uitkeringsvoorwaarden de laatste jaren slechter geworden (Herweyer, 1987). 
De WAO (zie Van Zaal, 1974 bijvoorbeeld) geldt voor alle loontrekkenden in de particuliere sfeer; om uitkeringsgerechtigd te worden is het niet de vraag hoe men arbeidsongeschikt is geworden, maar volstaat het dat men arbeidsongeschikt is. De WAO geeft een uitkering tot aan het $65^{*}$ jaar, waarvan de hoogte afhangt van het laatstverdiende loon toen men nog werkte en van het percentage arbeidsongeschiktheid. De uitvoering van de WAO is in handen van de bedrijfsverenigingen die medisch worden geadviseerd door de Gemeenschappelijke Medische Dienst (GMD). De regeling voor alle Nederlandse ingezetenen is de Algemene Arbeidsongeschiktheidswet ( $A A W$ ), een volksverzekering die sinds 1976 van kracht is. Voor arbeidsongeschikte ambtenaren geldt de Algemene Burgerlijke Pensioenwet (ABP-wet) die ook regels geeft voor de herplaatsing van gedeeltelijk arbeidsgeschikten via het Algemeen Burgerlijk Pensioenfonds (ABP). Het onderzoek dat hier aan de orde is, betreft werknemers in particuliere bedrijven en bij de overheid (zie paragraaf 3.1); de AAW is hier daarom niet relevant; de arbeidsongeschikten in het onderzoek vallen onder de WAO en de $\mathrm{ABP}$ - wet.

De definities van arbeidsongeschiktheid in de WAO en de ABP-wet lijken sterk op elkaar. We geven daarom als voorbeeld alleen de omschrijving in de WAO (artikel 8, lid 1): "Arbeidsongeschikt, geheel of gedeeltelijk is hij die ten gewolge van ziekte of gebreken geheel of gedeeltelijk niet in staat is om met arbeid te verdienen, hetgeen gezonde personen, met soortgelijke opleiding en ervaring, ter plaatse waar hij arbeid verricht of het laatst heeft verricht, of in de omgeving daarvan, met arbeid gewoonlijk verdienen".

In beide wetten is de arbeidsongeschiktheid in een aantal trappen verdeeld, die lopen van $15-25 \%$ tot en met $80 \%$ of meer en die corresponderen met een gegeven hoogte van de uitkering (WAO artikel 21, ABP - wet artikel F9; lid 5). Sinds kort geldt er een wijziging in de sociale zekerheidsregelingen warbij ook de arbeidsongeschiktheidswetten veranderd zijn (Ministerie van Sociale Zaken en Werkgelegenheid, 1987). Oorspronkelijk werd rekening gehouden met de situatie van de arbeidsongeschikte op de arbeidsmarkt en daarom werd een "werkloosheidsdeel' aan de arbeidsongeschiktheidsuitkering toegevoegd. Dit is afgeschaft; is nu iemand deels arbeidsongeschikt, deels werkloos, dan komt hij voor dit laatste in de Nieuwe Werkloosheidswet (NWW) en na verloop van tijd in de Inkomensvoorziening voor Oudere en gedeeltelijk Arbeidsongeschikte werkloze 
Werknemers (IOAW). De wijziging betreft niet de definitie van arbeidsongeschiktheid, maar de uitkeringsregeling en heeft dus woor ons onderzoek geen consequenties,

De WAO-uitkering vereist een wachttijd van 52 weken met minstens $15 \%$ arbeidsongeschiktheid, aan het eind van de wachttijd moet dat percentage nog minstens $15 \%$ zijn, en de uitkering eindigt als de werknemer 65 jaar wordt. De eis van de wachttijd komt meestal neer op de maximum-uitkeringsduur van de Ziektewet.

De Ziektewet verzekert werknemers tegen verlies van inkomen door arbeidsongeschiktheid over maximaal een jaar. Daarna kan de werknemer voorgedragen worden voor een keuring voor de WAO. Die keuring wordt niet geëist door de Ziektewet, maar door de WAO. Overeenkomstige regelingen zijn er in de ABPwet voor ambtenaren.

\subsubsection{Diagnoses bij arbeidsongeschiktheid}

Arbeidsongeschikt wordt men door ziekte of gebrek (paragraaf 2.2.1) en deze moeten door een verzekeringsarts worden vastgesteld. Er is dus een medische diagnose nodig, wil een werknemer een uitkering wegens arbeidsongeschiktheid krijgen.

Van verschillende kanten is twijfel geuit over de waarde van diagnosen bij arbeidsongeschiktheid. Giel (1977) wijst erop, dat het menselijke beslissingen zijn van een arts die beînvloed wordt door de cultuur en dat het vaak gaat om tegengestelde belangen van werknemer en werkgever, waardoor de arts zich in een dilemma bevindt. Koten \& Timmer (1980) menen verder dat de internationale classificatie van ziekten en afwijkingen, de ICD (WHO, 1980) beter past bij acute aandoeningen dan bij chronische- en resttoestanden zoals bij de arbeidsongeschikten. Duckworth (1982) en Nagi (1987) signaleren dat er veel spraakverwarring heerst, omdat er te weinig onderscheid wordt gemaakt tussen pathologie, handicaps, functionele beperkingen en arbeidsongeschiktheid. Nagi voegt hier aan toe, dat functionele beperkingen veel betere indicatoren zijn van arbeidsongeschiktheid dan vastgestelde handicaps ('impairment') en pathologie. Wickström 
(1982) vindt los daarvan de klinische diagnostiek op zichzelf inexact. Verder stellen Van der Willige e.a. (1983) dat ziekte en gezondheid geen echte tweedeling vormen en dat er om die reden geen exactheid te verwachten is. Van der Putten (1983) vindt de verschillen tussen groeperingen binnen het overheidspersoneel in het vórkomen van diagnosen zo groot, dat er aan de validiteit van deze beslissingen getwijfeld moet worden. Van Mansvelt e.a. (1974a, b) stelt bovendien nog dat de beslissing niet steeds op zuiver medische gronden genomen wordt en dat uitkeringen op zichzelf invaliderend kunnen werken. Haveman (1987) vraagt zich af of door de werknemer zelf wargenomen gezondheidsbeperkingen geen betere voorspellers van arbeidsongeschiktheid zijn dan de uitkomsten van medisch onderzoek. Kabela (1988) onderzocht de psychiatrische beoordeling van de arbeidsongeschiktheid en kwam daarbij tot de conclusie dat de betrouwbaarheid van dit oordeel niet groot is. Aarts \& De Jong (1990) gaan nog verder; zij stellen niet de geldigheid van de diagnose aan de orde, maar menen dat deze weinig belangrijk is, omdat WAO-toetreding volgens hun onderzoek voornamelijk afhangt van afwegingen door individuele werknemers en hun werkgevers.

Hoewel het onderzoek niet over diagnoses zal gaan, volgt hier toch achtergrondinformatie over de aandoeningen bij arbeidsongeschiktheid. Er zijn redenen om aan te nemen dat afkeuringen vaak gebaseerd zijn op combinaties van aandoeningen (Aling, 1969), maar is er één duidelijk patroon in de hoofddiagnoses?

We kunnen ons afvragen of er kenmerkende verschillen tussen de diagnosen bij uiteenlopende typen bedrijven zijn: verschillende bedrijfstypen zouden hun specifieke risico's kunnen hebben, die tot uiting komen in de verdeling van de diagnosen. Als beste benadering van het bedrijfstype is de bedrijfsvereniging (BV) opgenomen. De diagnosen zijn voor de overzichtelijkheid in vier groepen ingedeeld: psychosen en zenuwstelsel, hart/waatstelsel, bewegingsapparaat en overige diagnosen. Tabel 2.1 geeft de cijfers.

Om met het minst specifieke te beginnen: de categorie 'overige diagnosen' laat overwegend percentages van 50 a $60 \%$ zien. Twee bedrijfsverenigingen wijken daarvan af: de Baggeraars met $34.2 \%$ en het ABP met $70.3 \%$; voor de eerstgenoemde zijn de diagnosegroepen 'psychosen en zenuwstelsel', 'hart/vaatstelsel' en 
Iabel 2.1 Procentuele verdelingen per bedrijfsverenïging van viler diagnosekategorieën, opgekomen gevallen AAH/WA, 1980 (gebaseerd op gegevens van de socilale verzekeringsraad)

\begin{tabular}{|c|c|c|c|c|c|c|}
\hline $\begin{array}{l}\text { bedrifts. } \\
\text { vereniging }\end{array}$ & dantal & $\begin{array}{l}\text { psychosen en } \\
\text { zenuwstelsel }\end{array}$ & $\begin{array}{l}\text { hart/vart- } \\
\text { s.relsel }\end{array}$ & $\begin{array}{l}\text { bewegings- } \\
\text { apparaat }\end{array}$ & overige & totas \\
\hline BVAB $^{1)}$ & 3066 & 18.2 & 9.4 & 14.9 & 57.5 & 100.0 \\
\hline Zuivet & 435 & 22.6 & 10.4 & 18.3 & 48.7 & 100.0 \\
\hline Hout & 845 & 22.3 & 9.9 & 94.9 & 52.9 & 100.0 \\
\hline Textiel & 524 & 20.7 & 10.4 & 16.3 & 52.6 & 100.0 \\
\hline Leder & 193 & 20.1 & 8.7 & 15.4 & 55.8 & 100.0 \\
\hline GVB $^{2)}$ & 911 & $21 . \|$ & 9.0 & 14.4 & 55.8 & 100.0 \\
\hline Steen & 682 & 14.7 & 8.9 & 1.4 .6 & 61.8 & 100.0 \\
\hline \multicolumn{7}{|l|}{ Metaal- } \\
\hline industrile & 4281 & 19.4 & 6.9 & 12.2 & 61.5 & 100.0 \\
\hline \multicolumn{7}{|l|}{ Metaal. } \\
\hline nîj jverheid & 3930 & 18.7 & 8.0 & 12.6 & 60.7 & 100.0 \\
\hline Mijinen & 161 & 16.5 & 12.3 & 24.7 & 46.5 & 100.0 \\
\hline Chemie & 1173 & 19.9 & 9.5 & 11.8 & 58.8 & 100.0 \\
\hline Tabak & 166 & 22.0 & 11.9 & 25.4 & 40.7 & 100.0 \\
\hline Bakkers & 1118 & 20.0 & 10.0 & 14.4 & 55.6 & 100.0 \\
\hline slagers & 1117 & 21.8 & 9.6 & 14.7 & 53.9 & 100.0 \\
\hline Voeding & 1211 & 21.3 & 6.9 & 12.4 & 59.4 & 100.0 \\
\hline Detan $\left.{ }^{3}\right)$ & 7700 & 18.0 & 9.2 & 11.1 & 61.7 & 100.0 \\
\hline HaBivi & 918 & 20.2 & 8.9 & 15.8 & 55.1 & 100.0 \\
\hline Koopvaardi j & 282 & 22.3 & 8.2 & 17.6 & 51.9 & 100.0 \\
\hline Verwoer & 2209 & 22.8 & B. 7 & 13.6 & 54.9 & 100.0 \\
\hline Horeca & 1912 & 18.7 & 8.2 & 12.1 & 61.0 & 100.0 \\
\hline $\mathrm{BNG}^{5)}$ & 10329 & 20.9 & 8.3 & 11.3 & 59.5 & 100.0 \\
\hline Overheid & 4748 & 22.7 & 8.7 & 13.1 & 5.5 .5 & 100.0 \\
\hline Ganken & 8799 & 18.9 & 7.8 & 9.1 & 65.0 & 100.0 \\
\hline $\operatorname{MAB} B^{67}$ & $B 304$ & 19.2 & 8.3 & 10.5 & 62.0 & 100.0 \\
\hline Bouiw & 6693 & 20.2 & 7.6 & 16.6 & 55.6 & 100.0 \\
\hline Schillders & 833 & 20.0 & 11.0 & 16.0 & 53.0 & 100.0 \\
\hline Deggers & 152 & 28.6 & 1.4 .3 & 22.9 & 34.2 & 100.0 \\
\hline Wakli i $1^{7}$ & 126 & 23.1 & 5.8 & 13.5 & 57.6 & 100.0 \\
\hline$A B P^{8}$ & 13590 & 14.9 & 7.0 & 7.8 & 70.3 & 100.0 \\
\hline HSP 9 & 473 & 23.3 & 14.0 & 14.0 & 48.7 & 100.0 \\
\hline
\end{tabular}
1) Agrarische bedrijfstak
2) Grafische bedrijuen
3) Detail thandel, ambach ten huiswrouwen
4) Haven en abnverwant, binnenscheepvalart en visserij
5) Gezondheidszorg
6) Nieuwe Algemene Bedrijfswereniging: witeenlopende bedrijfstypen
7) Milittairen
Q) ABP-ambtenaren
9) Spoorwegen 
'bewegingsapparaat' blijkbaar heel kenmerkend voor deze BV. Zo globaal gezien zijn er al aanzienlijke verschillen in de verdeling naar diagnose tussen de bedrijfsverenigingen.

Bezien we elke diagnosecategorie afzonderlijk, dan blijken er eveneens aanzienlijke verschillen te zijn. Binnen de groep 'psychosen en zenuwstelsel" variëert het percentage van $14.7 \%$ (Steen) tot $28.6 \%$ (Baggers). Binnen de categorie 'hart/vaatstelsel' loopt het van $5.8 \%$ (WaMil) tot $14.3 \%$ (weer Baggers), en in de categorie 'bewegingsapparaat' van $7.8 \%$ (ABP) tot $25.4 \%$ (Tabak). Er zijn dus verschillende aanwijzingen dat $B V$ 'en onderling grote verschillen kunnen vertonen in de diagnosecategorieeën bij $\mathrm{AAW} / \mathrm{AOW}$-intrede.

$\mathrm{Nu}$ is het aantal diagnosen in sommige BV'en laag: voornamelijk bij Leder, Mijnen, Tabak, Baggers en WaMil. Extreem hoge of lage percentages bij deze BV'en kunnen het gevolg zijn van statistische fluctuatie. Om deze tegen te gaan kunnen we, om de gedachten te bepalen, een minimum-aantal diagnosen verlangen van zeg: duizend. Dan blijven er zestien van de dertig BV'en over. Toch blijven er bij dit criterium een aantal opmerkelijke verschillen in de percentages bestaan. Nu zijn extremen bij "psychosen en zenuwstelsel' $14.9 \%$ (ABP) tegenover $22.8 \%$ (Vervoer), bij 'hart/vaatstelsel' $6.9 \%$ (Metaalindustrie en Voeding) tegenover $10.0 \%$ (Bakkers), en bij de categorie 'bewegingsapparaat' $9.1 \%$ (Banken) tegenover $16.6 \%$ (Bouw). De eerdere conclusie dat er grote verschillen in diagnosen. tussen de BV"en zijn, kunnen we dus handhaven.

Van der Putten (1983) deed onderzoek aan de hand van dossiers van arbeidsongeschikten bij het overheidspersoneel. Er kwam naar voren dat afwijkingen van het bewegingsapparaat vooral voorkomen bij lichamelijk belastende functies, en psychische stoornissen voornamelijk bij mentaal belastende functies. Er zijn geen redenen om aan te nemen, dat dit buiten het overheidspersoneel anders zou liggen. Van Dijk e.a. (1987) verrichtten onderzoek in een particulier bedrijf met ruim 20000 werknemers, van wie er 4000 in de loop van acht jaar arbeidsongeschikt werden. Hier bleek behalve een afname in de WAO-kans in de volgorde produktie-, schoonmaak-, onderhouds- en kantoorpersoneel een concentratie van WAO in drie categorieën, nl. psychische problemen, hart/vaatafwijkingen en bewegingsapparaat. Jongere werknemers bleken vaak in de groep 'psychische af- 
wijkingen' te komen en oudere werknemers in de groep 'hart/vaat". Schellart e.a. $(1989,1990 \mathrm{a}, \mathrm{b})$ vonden vergelijkbare verbanden binnen een steekproef van 326 WAO-gerechtigden: psychische ziekten overwegen bij de functies met matige tot zware psychische belasting, hart- en vaatziekten bij dezelfde groepen èn bij zwaarder fysiek werk binnenshuis, en ziekten van het bewegingsapparaat prevaleren bij functies die een matige tot zware fysieke belasting kennen. Uit de gegevens is de sterkte van het verband tussen functie- en diagnosegroep te berekenen (de contingentiecoëfficiënt $c=0.33$ ), dit verband is niet erg sterk. Karasek e.a. (1987) onderzochten 5000 mannelijke en 3700 vrouwelijke werknemers. $\mathrm{Zij}$ konden geen samenhang vinden tussen specifieke stressoren en bepaalde ziekten. Er zijn dus wel werbanden tussen type werk en type diagnose, maar deze zijn niet altijd even overtuigend.

De drie categorieën psychische ziekten, afwijkingen van het hart/vaatstelsel en van het bewegingsapparaat vormen in beide reeksen gegevens de meerderheid van alle diagnosen. In het ABP zijn meer psychische ziekten, bij de GMD zijn er meer afwijkingen van het bewegingsapparatt en meer "overige ziektebeelden". Wat betreft psychologische diagnostiek bij arbeidsongeschiktheid kan verwezen worden naar een onderzoek door Lancée (1988). Deze stelt dat in volgorde van afnemend belang bij arbeidsongeschiktheid meespelen: emotionele labiliteit, de neiging klachten lichamelijk te uiten, psychopathologie en lage intelligentie.

Verondersteld mag worden dat de diagnosen bij de arbeidsongeschikten uit de vier hier relevante bedrijven in grote trekken dezelfde zijn als in tabel 2.1.

We kunnen concluderen, dat de diagnosen bij arbeidsongeschiktheid feilbaar zijn, maar dat in het algemeen afwijkingen van het bewegingsapparaat, psychische ziekten en hart/vaatziekten de belangrijkste diagnosen bij arbeidsongeschiktheid zijn, waarbij de eerste twee voorop staan, afhankelijk van het type werk. De tendentie is, dat bij hoofdwerk de psychische ziekten en bij handwerk de afwijkingen van het bewegingsapparaat domineren. De literatuur geeft echter verschillende redenen om geen absolute waarde aan de diagnose bij arbeidsongeschiktheid te hechten. Wel is door Van der Horst (1988) aangetoond dat arbeidsongeschikten afwijken van werkenden, werklozen en vervroegd gepensioneerden; de arbeidsongeschikten hebben een subjectief en objectief slechtere gezondheid dan de andere drie groepen. Het is daarom zinvol, los van alle diagnoses na te 
gaan welke verschillen tussen later wel- en niet-arbeidsongeschikte werknemers in hun eerdere verzuim en hun meningen over hun arbeidssituatie een voorspelling van naderende arbeidsongeschiktheid mogellik maken.

\subsubsection{Percentages arbeidsongeschiktheid}

Door de WAO en ABP-wet worden (zie paragraaf 2.2.1) een aantal klassen van arbeidsongeschiktheid onderscheiden. De spreiding van witkeringsgerechtigden over deze klassen is niet gelijkmatig, zoals blijkt uit de cijfers van tabel 2.2.

Tabel 2.2 Landelijke verdelingen van uitkeringsigerechtigden (mannen en vrouwen) over de $k$ lassen van arbeidsongeschiktheid

\begin{tabular}{lcc}
\hline percentage arbeidsongeschilkt & GMD 1986 & ABP $1986 *$ * \\
\hline nogl vast te stellen/ & & 1.6 \\
kleiner dan 15\% & -1.2 & 1.0 \\
$15-25 \%$ & 1.6 & 1.4 \\
$25-35 \%$ & 1.1 & 1.1 \\
$35-45 \%$ & 5.6 & 2.8 \\
$45-55 \%$ & 1.5 & 1.0 \\
$55-65 \%$ & 1.6 & 0.8 \\
$65-80 \%$ & 87.4 & 90.8 \\
$80-100 \%$ & $100.0 \%$ & $100.0 \%$ \\
\hline
\end{tabular}

* nieuwe uitkeringsgerechtigden eind 1986 (GMD, 1987)

* afgedane meldingen in 1986 , door afrondingen niet precies $100,0 \%$ (ABP "1987)

Rond $90 \%$ van alle gevallen komt in de hoogste klasse terecht, bij het ABP zelfs meer dan bij de GMD. In het vervolg zal daarom alleen gerekend worden met arbeidsgeschikten en niet-arbeidsongeschikten, net als in Van Dijk e.a. (1987). De klasse $0-15 \%$ telt daarbij als niet- en alle andere klassen tezamen als welarbeidsongeschikt.

De cijfers van tabel 2.2 zouden kunnen suggereren dat een eenmaal aan een werknemer toegekend percentage arbeidsongeschiktheid onveranderd zou blijven. Is die indruk juist? Eenmaal opgetreden arbeidsongeschiktheid hoeft niet 
stabiel te zijn, zoals Chirikos en Nestel (1981) in de Amerikaanse situatie vaststelden. Geldt dit ook voor Nederland? Een schatting van het Algemeen Arbeidsongeschiktheidsfonds (1983) is dat ruim de helft van de mannelijke en ruim drie kwart van de vrouwelijke uitkeringsgerechtigden na verloop van tijd hersteld zijn of in de laagste klasse van arbeidsongeschiktheid (15\% of minder) terecht komen. Een onderzoek van Lenshoek e.a. (1988) wees uit dat na tweeënhalf jaar een derde van de meer of minder arbeidsongeschikt verklaarden weer bij het eigen bedrijf gereintegreerd was. Men moet daarom in het oog houden dat de landelijke verdeling naar percentage arbeidsongeschiktheid min of meer stabiel is, maar dat dit niet zonder meer voor de individuele werknemer geldt.

Hoewel de arbeidsongeschiktheid dus niet altijd irreversibel is, kan hij ook verergeren. Er is dus alle reden om arbeidsongeschiktheid te voorkomen door primaire preventie.

\subsubsection{Economische oorzaken van arbeidsongeschiktheid}

Uit een literatuurstudie van Martens en Grosfeld (1979) blijkt dat de kennis van de oorzaken van arbeidsongeschiktheid lange tijd gering geweest is. Pas rond die tijd komen er meer publikaties. Sterrenberg (1978) wees op verschillen tussen bedrijfstakken, waarbij bedrijfstakken met een krappe arbeidsmarkt weinig arbeidsongeschikten kennen en andersom. Ook werd gesignaleerd dat de landelijke sterfte af nam, terwijl de arbeidsongeschiktheid in omvang toenam. Die groei zou dus niet zijn veroorzaakt door een algemene verslechtering van de gezondheidstoestand, maar door andere factoren (Hilverink, 1978; zie echter verderop Groothoff, 1986). Douben en Herweyer (1979) wijzen op verschillen tussen bedrijfstakken om verschillen in arbeidsongeschiktheid te verklaren. Ook werd verondersteld dat de arbeidsongeschiktheidsregelingen gebruikt zouden kunnen worden als een verkapte vorm van vervroegde pensionering (Herweyer, 1981; Aarts \& De Jong, 1990).

Van den Bosch \& Petersen (1980a, b; 1981; 1982a, b) vergelijken de toenamen in aantallen arbeidsongeschikten bij WAO en $\mathrm{ABP}$. Zij stellen dat de eerste sterk toeneemt onder invloed van de verslechterende economie, wat bij de tweede niet 
het geval zou zijn en hun conclusie is, dat daarom een deel van de WAO-ers eigenlijk werklozen zijn. Van den Bosch \& Petersen schatten dat het aandeel van de verborgend werkloosheid in de periode $1968-1979$ opliep van $6 \%$ tot $42 \%$. Hunfeld (1980) brengt tegen deze economisch georiënteerde studies onder meer in, dat ze voorbijgaan aan het volgens hem meest wezenlijke, nl. de psychosociale kant van het probleem. Hunfeld meent dat de niet-economische factoren in het invalideringsproces door Van den Bosch \& Peters onvoldoende worden uitgesloten als oorzaak van het verschil in invalideringsfrequenties tussen WAO en ABP. Een andere criticus is Treffers (1980) die er onder meer op wijst, dat de veronderstelling van Van den Bosch \& Petersen, n.l. dat de rendementseis alleen in particuliere bedrijven zou gelden, onjuist is. Overheids- en particuliere bedrijven zijn onderworpen aan economische beperkingen die voor zowel WAO als ABP gevolgen hebben. Het lagere aantal afkeuringen bij de overheid is volgens Treffers een gevolg van gerichte aanstellingskeuringen en herplaatsingen. Sinds de wijziging van de sociale zekerheid (zie paragraaf 2.2.1) zouden arbeidsongeschiktheid en werkloosheid scherper uit elkaar gehouden kunnen worden. Overigens zijn de meer recente schattingen van de verborgen werkloosheid lager dan die van Van den Bosch \& Petersen (op. cit.); Van der Horst (1988) komt tot een schatting van $17 \%$, Vrooman \& De Kemp (1990) schatten 14\%. De discussie die door Van den Bosch \& Petersen in gang gezet werd, is zodoende theoretisch en empirisch misschien achterhaald.

Een andere algemene invloed op de arbeidsongeschiktheid wordt behandeld door Groothoff (1986). Deze bestudeerde de periode 1958 - 1978 en kwam tot de slotsom dat in Nederland de gezondheidstoestand van de werkende bevolking achteruitging, tegelijk met een toename in het aantal arbeidsongeschikten. Eerder bleek al (Chirikos, 1986) dat die laatste toename niet specifiek voor Nederland is, maar dat deze kenmerkend zou kunnen zijn vaor veel westerse landen. Theoretisch zou de achteruitgang van de gezondheid in de bevolking mede een gevolg kunnen zijn van een in de loop van de jaren verruimd ziektebegrip (Vrooman \& De Kemp, 1990). Koopmans \& Bijlsma (1990) concluderen echter in hun onderzoek dat van een algemene uitbreiding van het ziektebegrip geen sprake is.

Er zijn kortom meerdere opvattingen over de economische achtergronden van arbeidsongeschiktheid (algemene achteruitgang in de gezondheid, verschillen 
tussen bedrijfstakken, onduidelijke afgrenzing van arbeidsongeschiktheid met VUT en werkloosheid) maar dit zijn erg globale en soms weinig overtuigende verklaringen, die een meer concrete bedrijfs- of indiwidugerichte benadering van de arbeidsongeschiktheid bepaald niet overbodig maken.

\subsubsection{Bedrijfsgebonden oorzaken van arbeidsongeschiktheid}

Door Phillipsen (1969), Dijkstra (1977) en Smulders (1984a) is aangetoond dat het verzuimniweau karakteristiek voor een organisatie kan zijn. Draaisma (1983) vond verder dat de combinatie van verzekerings- en controlevorm voor de Ziektewet verschil maakt in het aantal WAO-gevallen per jaar. Dit is het laagst in bedrijven die aangesloten zijn bij een "afdelingskas" of die eigen-risicodrager zijn, en warbij de controle verdeeld is tussen het bedrijf en het Gemeenschappelijk Administratiekantoor. Er is meer WAO-toetreding in bedrijven die 'omslaglid' zijn, d.w.z. waar de behandeling van de ziekengelden in handen is van de bedrijfswereniging.

Nijhuis \& Soeters (1982) onderzochten de verbanden tussen bedrijfskenmerken en aantallen arbeidsongeschikten; ook Soeters (1983) doet hier:verslag van. WAO-toetreding hangt met een aantal bedrijfsvariabelen samen en dit verklaren zij uit het volgende proces. Economische recessie leidt tot pogingen de produktie te rationaliseren, onder meer door intensivering van het werk. Dit heeft een verhoogde arbeidsbelasting tot gevolg die kan leiden tot overbelasting en ziekte of tot arbeidsongeschiktheid op basis wan een al langer bestaande aandoening.

Van "t Hullenaar en Van Koningsveld (1986) kregen inzage in GMD-dossiers. Bij 10 van de 22 dossiers van oudere werknemers bleek de oorsprong van de problemen samen te hangen met inkrimping of reorganisatie van de onderneming. Bij $28(80 \%)$ van de 35 dossiers in totaal speelden naast kenmerken van de persoon ook de werkomstandigheden mee in het arbeidsongeschikt worden. Hun conclusie is dat het laatste behalve van de leeftijd ook afhangt van het verloop van de ziekte en het verloop van de reorganisatie. 
Kerkhoff (1981) beschrijft hoe in sommige bedrijven slechts weinig werknemers het normale ouderdomspensioen bereiken, doordat velen voor die tijd arbeidsongeschikt worden. Verbeek \& Geurts (1987) wijzen in hetzelfde verband op verschillen tussen typen werk. Binnen een aantal gemeentediensten bleek arbeidsongeschiktheid vooral op te treden bij diensten waar het werk veel lichamelijke inspanning vereist (verg. Van der Putten, 1983). Aarts e.a. (1981) en De Jong e.a. (1981) wijzen verder op de invloed van beleid gericht op aanpassing van het werk aan de werknemer. Dit vermindert het aantal arbeidsongeschikten, maar de mogelijkheden hangen af van de economische speelruimte van het bedrijf. Dit sluit aan bij de conclusies van Van den Bosch en Petersen (1982b). Ook Aarts (1984) bevestigt dat bedrijfsfactoren invloed hebben, maar hij relativeert de invloed van bedrijfsbeleid, gericht op functieaanpassing. Koopmans \& Bijlsma (1990) betogen dat niet het bedrijf, maar meer de bedrijfstak met de arbeidsongeschiktheid te maken heeft; bedrijfsverenigingen in sectoren met een ongunstige werkgelegenheid kennen een hoog WAO-risico en weinig herstellgevallen die de WAO weer verlaten; bij bedrijfsverenigingen met een gunstige situatie ligt dit andersom.

Net als het verzuim blijkt ook de arbeidsongeschiktheid karakteristiek voor een arbeidsorganisatie of een groep gelijksoortige organisaties (nl. de bedrijfsvereniging) te kunnen zijn. Er zijn verschillende groepen bedrijfsfactoren die te maken kunnen hebben met arbeidsongeschiktheid; onder meer de werkgellegenheid, het type werk (fysiek dan wel psychisch meer of minder zwaar), reorganisaties en de economische mogelijkheden om het werk aan minder validen aan te passen. $\mathrm{Na}$ valt te gaan wat er bovendien voor individugebonden factoren in de arbeidsongeschiktheid meespelen.

\subsubsection{Persoonsgebonden oorzaken van arbeidsongeschiktheid}

De vragen wie er arbeidsongeschikt worden en waardoor men arbeidsongeschikt wordt lopen in de literatuur soms door elkaar. We zullen proberen deze vragen gescheiden te beantwoorden. De eerste vraag is dan, wie de arbeidsongeschikten zijn. De verdeling naar leeftijd wan de WAO-gerechtigden is als in tabel 2.3. 


\begin{tabular}{|c|c|c|}
\hline leeftijd & aantal & percentage \\
\hline $\mathrm{t} / \mathrm{mi} 24$ jaar & 26500 & $3.6 \%$ \\
\hline 25- 34 Jaar & 78700 & $10 . \pi$ \\
\hline $35-44$ jaar & 135500 & $18.4 \%$ \\
\hline 45- 54 jear & 2009000 & $27.3 x$ \\
\hline $55-64 j$ atar & 294800 & $40.0 \%$ \\
\hline total. & 736400 & $100.0 \%$ \\
\hline
\end{tabular}

* bron: Gemeenschappell ijke Medische Di ienst, 1988

Een opmerking over het totaal-aantal hier en in tabel 1.1. In tabel 1.1 (voetnoot 3) is sprake van uitkeringsjaren, in tabel 2.3 van uitkeringsgerechtigden. Daardoor zijn de aantallen van tabel 1. .J en 2.3 niet helemaal gelijk.

Uit tabel 2.3 is duidelijk dat het aantal arbeidsongeschikten sterk met de leeftijd toeneemt. Dat klopt met bijvoorbeeld Einerhand (1986) die laat zien dat arbeidsongeschikten (net als werklozen en uiteraard gepensioneerden) betrekkelijk oud zijn en laaggeschoold en met Aarts e.a. $(1982 \mathrm{~b}, \mathrm{c})$ die vinden dat de WAO-er betrekkelijk oud is en in een slechte inkomenspositie verkeert. Maar verder (nog steeds Aarts e.a.) heeft de arbeidsongeschikte weinig verbondenheid met de werkgever, hij heeft weinig scholing en hij is jong begonnen met lichamelijk zwaar werk met weinig promotiemogelijkheden. Meestal bestaan er bij het arbeidsongeschikt-worden al langer gezondheidsproblemen en de arbeidsongeschikte heeft verder weinig kansen op de arbeidsmarkt.

Goudrïaan e.a. (1982) vinden dat de arbeidsongeschiktheid in het onderwijs sterker elders afhankelijk is van de leeftijd. Er zijn daar minder werknemers die gezond de pensioengerechtigde leeftijd bereiken dan in andere groepen ABPverzekerden. Meer dan de helft van de afkeuringen in het onderwijs vindt plaats op grond van psychische ziekten, wat volgens de auteurs een bewijs is voor overbelasting. 
Kruidenier (1980) noemt als eigenschappen van de arbeidsongeschikte: hij heeft weinig scholing, daardoor weinig kans op de arbeidsmarkt, en hij is langdurig overbelast geweest. Wiersma $(1979,1980)$, Bax (1984) en Besseling e.a. (1987) hebben soortgelijke verklaringen. Kruidenier bestrijdt de opvatting dat de stijging in de arbeidsongeschiktheid te verklaren zou zijn uit verborgen werkloosheid en Kruidenier (1982a) herhaalt dit: verzuim en arbeidsongeschiktheid zijn volgens hem in de eerste plaats gezondheidsproblemen, waarbij de eigen beslissingsvrijheid van de werknemer gering is. Handarbeiders zouden daardoor meer risico van arbeidsongeschiktheid lopen dan hoofdarbeiders. Daarbij voert Kruidenier als bijkomend argument aan, dat er een toename in de sterfte is onder zowel mannen als vrouwen die toe te schrijven is aan een algemene toename van de belastende arbeidsomstandigheden (vergelijk Soeters, 1983).

Sol (1983a, b) schetst de arbeidsongeschiktheid in de bouwnijverheid. Er zijn daar veel afkeuringen op relatief jeugdige leeftijd, rond de veertig jaar. Niet alleen de kans op een aandoening is hier hoger dan in andere bedrijfstakken, ook de kans op afkeuring, gegeven een aandoening, is erg hoog. Roeleveld e.a. (1982) geven een beeld van de WAO-er in de grafische industrie, dat meer lijkt op wat Kruidenier geeft: uitkeringsgerechtigden zijn vrij oud, hebben weinig opleiding en hebben langdurig lichamelijk zwaar werk gedaan, vaak onder belastende omstandigheden. Dit komt voortdurend terug in de meeste beschrijvingen, zoals in die van Kers en Bruinsma (1989); het kan daarom gelden als samenvatting van de betreffende literatuur.

\subsubsection{De invloed van de arbeidsbelasting op het arbeidsongeschikt-worden}

Aan het tot nu toe geschetste beeld over de veroorzaking van arbeidsongeschiktheid ontbreekt het aspect "arbeidsbelasting". Kortbeek (1974) veronderstelt dat arbeidsongeschiktheid voornamelijk een zaak is van cumulatie van arbeidstaken. Dat werkdruk invloed heeft wordt ook geconcludeerd in het Determinantenonderzoek WAO (De Jong e.a., 1981; Aarts e.a., 1981). De werklast heeft op zijn beurt te maken met de economische gezondheid van het bedrijf en de bereidheid, het werk aan de werknemers aan te passen. Vindt die aanpassing niet plaats en kan een werknemer zelf zich niet langer aanpassen, dan wordt hij overbelast 
en uiteindelijk ziek. Is hij eenmaal ziek, dan hangt zijn kans op arbeidsongesehiktheid verder af van voornamelijk zijn beperkingen die samenhangen met de leeftijd.

Kerkhoff (1981) veronderstelt dat bij veel uitvoerend werk structurele factoren aanwezig zijn, die tot slijtage kunnen leiden. Roeleveld e.a. (1982) zien in de grafische industrie aanwijzingen voor zowel mentale als lichamelijke belasting. Daarbij spelen de wijze van leidinggeven en de organisatie van het werk geen belangrijke rol, net zo $\mathrm{min}$ als de fysieke werkomgeving. De arbeidsongeschiktheid in de grafische sector zou dus samenhangen met de arbeidsinhoud en niet met de fysieke of de organisatorische arbeidsomstandigheden.

In een longitudinaal onderzoek werd door Astrand e.a. 1988) onderzocht of klachten op onder meer de Cornell Medical Index (zie Abramson, 1966), metingen van aspecten van de belastbaarheid en oordelen van artsen en van chefs over het functioneren wan werknemers verband houden met latere arbeidsongeschiktheid. De medisch beoordeelde belastbaarheid bleek hier de enige goede voorspeller te zijn, gevolgd door de beoordeling door de chef. De subjectieve uitspraken van de werknemer bleken bij Astrand e.a. vrijwel geen voorspellende waarde te hebben ten aanzien van arbeidsongeschiktheid. Dit resultaat is voor ons onderzoek bijzonder relevant, omdat een van de onderzoeksvragen juist is of werknemersmeningen, verkregen met de VAG (zie paragraaf 1.3), bruikbaar zijn als voorspeller van vertrek (arbeidsongeschiktheid, VUT of ontslagname).

Een ander voorbeeld van longitudinaal onderzoek is Van 't Hullenaar en Van Koningsveld (1982, 1986). $\mathrm{Zij}$ volgden 454 werknemers een jaar lang; achtenzestig van hen werden arbeidsongeschikt. De auteurs concluderen dat voor werknemers in alle leeftijdsgroepen een hoge belasting leidt tot verzuim en arbeidsongeschiktheid. Er zijn daarbij leeftijdsgebonden invloeden die de kans op WAO bepalen, maar de aard van het proces dat ertoe leidt is voor alle leeftijdsgroepen gelijk.

Kompier (1988) vond in onderzoek onder stadsbuschauffeurs dat in de vier jaar voor de arbeidsongeschiktverklaring een toename te zien is in het verzuim en verder dat de later afgekeurden al vroeg problemen uiten van vermoeidheid en 
slechte kwaliteit van de slaap. Dit werd bevestigd in een transversaal onderzoek van vijf groepen chauffeurs, gerangschikt volgens oplopende verzuimfrequentie (drie groepen), afgekeurden die herplaatst werden, en tenslotte de volledig afgekeurden. In deze volgorde bleken de problemen met roostertijdsdruk, slaapkwaliteit en ervaren gezondheid toe te nemen.

In het al eerder genoemde 'Determinantenonderzoek WAO' (De Jong e.a., 1981) bleken fysieke belasting, leeftijd en verzuim in thet verleden positief samen te hangen met arbeidsongeschiktheid en promotiemogelijkheden negatief. Het laatste waarschijnlijk omdat bevorderingsmogelijkheden samengaan met hoofdwerk en een lage kans op WAO.

Het meest recente werk dat hier vermeld kan worden is Draaisma e.a. (1989). In dit longitudinale onderzoek onder ruim 500 uitvoerders in bouwbedrijven (leidinggevend kader op de bouwplaats) gingen zij onder andere na, in hoeverre de gezondheid en de werksituatie op eeen tijdstip van invloed is op latere uittrede door arbeidsongeschiktheid. $\mathrm{Zij}$ onderscheiden drie leeftijdsgroepen; in de jongste (jonger dan 35 jaar) bleek in vier jaren geen arbeidsongeschiktheid voor te komen. Ook was de gezondheid van uitvallers om andere redenen (werkloosheid en ander werk) niet slechter.

Van de uitvoerders in de leeftijd van 35 tot 50 jaar viel in vier jaren bijna $10 \%$ uit door WAO-intrede. $\mathrm{Zij}$ bleken bij de eerste meting hoger te scoren op het persoonskenmerk 'moedeloosheid' en in wat mindere mate op medische consumptie. Variabelen met betrekking tot de werksituatie leverden geen eigen onafhankelijke bijdrage aan de WAO-intrede.

Van de uitvoerders van 50 jaar en ouder verdween tussen 1983 en $1987 \quad 17 \%$ naar de WAO. Hier blijkt de eerder ervaren toekomstonzekerheid en de ervaring, in het werk gehinderd te worden doordat men zich niet in orde voelt, WAO-intrede te voorspellen. Wat de werksituatie betreft is éen van de sectoren uit de bouw ( $\mathrm{nl}$. in bedrijven waar de uitvoerder wisselend in woning - en in utiliteitsbouw wordt ingeschakeld) de enige voorspeller; in deze sector is een grotere werkdruk dan in de andere sectoren. 
De belangrijkste determinanten van arbeidsongeschiktheid in deze publikaties zijn te herleiden tot een drietal: lichamelijk of geestelijk zwaar werk, eerder verzuim en toenemende leeftijd. Deze kunnen beschouwd worden als de grootste gemeenschappelijke deler van de hier behandelde arbeidsongeschiktheidsliteratuur. Ook als we deze determinanten van arbeidsongeschiktheid kennen, is daarmee nog niet aangegeven via welk mechanisme ze tot arbeidsongeschiktheid leiden. Eén zo een mechanisme zou slijtage door het werk kunnen zijn (Kerkhoff, 1981; Van 't Hullenaar \& Van Koningsveld, 1986). Het is echter ook mogelijk (Baart, 1973; De Boorder, 1979) dat er, los van enige slijtage een algemene achteruitgang in het arbeidsvermogen optreedt met toenemende leeftijd. Beide mogelijkheden worden overwogen door Kruidenier (1982b), die concludeert dat het autonome, biologische verouderingsproces en het slijtageproces in de arbeid elkaar kunnen versterken. Een mengvorm van slijtage- en achteruitgangshypothese is eveneens te vinden bij Kompier e.a. (1986) in een onderzoek bij buschauffeurs. Op een gegeven tijdstip kunnen deze niet meer goed herstellen van de arbeidsbelasting, ze gaan lang verzuimen en worden, als ze niet op tijd passend werk krijgen, arbeidsongeschikt.

Gezien het niveau van de arbeidsongeschiktheid in het onderwijs (Goudriaan e.a., 1982; Verbeek e.a., 1989) waar duidelijk geen sprake is van lichamelijke belasting, moet men zich de slijtage niet als een mechanisch proces voorstellen, maar eerder als een versnelde achteruitgang in de totale belastbaarheid van de werknemer. Iets dergelijks is ook de interpretatie van Draaisma e.a. (1989): knelpunten in de werksituatie leiden in eerste instantie tot overbelasting en vervolgens via verminderde gezondheid tot $\mathrm{WAO}$-intrede.

Er zijn dus verschillende opvattingen over het mechanisme achter de uitval door arbeidsongeschiktheid. Door Kompier (1988) en door Meijman (1988) zijn algemene modellen ontworpen die dit mechanisme willen verklaren. Het 'cumulatief procesmodel' van Kompier vat de arbeidshandeling op als resultaat van takeisen en het 'verwerkingsvermogen' van de persoon, omschreven als 'het vermogen tot presteren en trotseren". De arbeidshandeling heeft naast het arbeidsprodukt subjectieve, gedrags- en fysiologische gevolgen en deze gevolgen zijn gegradeerd van reversibele effecten via voorlopers van ziekte en -verzuim tot arbeidsongeschiktheid. Elk van de gevolgen kan in een terugkoppelingslus via een zekere 
mate van herstel invloed hebben op het verwerkingsvermogen van de persoon. Kernvraag is, of dit herstel voldoende is; is het dat niet, dan daalt het verwerkingsvermogen en ontstaan er problemen. Kan iemand niet van zijn normale arbeidsinspanning herstellen, dan treedt bijv, oververmoeidheid op; die kan gevolgd worden door verzuim en dat laatste weer door arbeidsongeschiktheid.

Het 'belasting/herstel-model' van Meijman (1988) wijkt op verschillende punten van het cumulatief procesmodel van Kompier af. Aan de gevolgenkant is het eenvoudiger; het kent geen gegradeerde effecten van de arbeidsinspanning, maar alleen een tweedeling wel of niet reversibel. Aan de takkant is het meer uitgewerkt omdat de arbeidshandeling niet alleen als resultaat van de taakeisen en de beschikbare arbeidscapaciteit wordt beschouwd, maar bovendien als afhankelijk van de werkomstandigheden en de regelmogelijkheden voor de werknemer zelf. De werknemer heeft daarmee een eigen 'verwerkingsstrategie' en die bepaalt de arbeidshandeling. Deze laatste leidt (vergelijk Kompier) zowel tot een arbeidsprodukt als tot effecten op de werknemer. Omkeerbare effecten hebben alleen betrekking op de werkcapaciteit van het moment; ook na sterke inspanning komt deze weer op zijn oude waarde. Onomkeerbare effecten echter tasten die capaciteit en daarmee ook de regelmogelijkheden voor de werknemer blijvend aan; hun optreden kan leiden tot uiteindelijke uitval door arbeidsongeschiktheid.

De beide modellen hebben gemeen, dat er via een terugkoppelingslus een onherstelbare wanverhouding tussen belasting en belastbaarheid kan optreden. Die lus moet bijtijds onderbroken worden, zodat de gelegenheid ontstaat om belasting en belastbaarheid aan elkaar aan te passen (zie hoofdstuk 1). Dat is mogelijk omdat (cumulatief procesmodel van Kompier) als niet ingegrepen wordt, de problemen in een aantal fasen kunnen verergeren totdat een werknemer uiteindelijk arbeidsongeschikt wordt. De opgave is, in een vroege fase te interveniëren en de vraag voor ons onderzoek is, of werknemers die op weg zijn arbeidsongeschikt te worden, in een vroeg stadium op te sporen zijn. 


\subsubsection{Achtergrond en kenmerken van VUT-regelingen}

Een van de vroegste publikaties over de VUT is te vinden in de Gids Personeelsbeleid (1975): het oorspronkelijke idee achter de VUT was, herverdeling van werk door flexibele pensionering; de FNV had hiervoor een plan dat gefinancierd had moeten worden uit de WW en WWV. De door vroeg gepensioneerde werknemers vrijgemaakte plaatsen zouden door werklozen bezet moeten worden, al werd ook door de FNV erkend dat de mogelijkheid hiertoe van de economische situatie zou afhangen.

Leemreize (1979) legde het vakbondsstandpunt over de herverdeling van arbeid nader uit; de VUT moest gekoppeld worden aan verbetering van de positie van de oudere werknemer. Ook hij signaleerde problemen met het vervullen van vrijgekomen arbeidsplaatsen en verder met het bereiken van een uniforme VUTregeling vanwege de wenselijke rechtsgelijkheid.

Belangrijk in de oorspronkelijke opvatting van de VUT was dus het streven naar de herverdeling van arbeid. Hoeveel is hiervan gerealiseerd? Volgens Van Ginneken (1981) en Hesemans (1988) is het effect op de werkgelegenheid gering. In 1979 waren er volgens Van Ginneken 9.000 VUT-gevallen waarvan goed de helft door jongere werknemers werd ingenomen. Voor de bouwnijverheid komt Sol (1984) tot eenzelfde conclusie: van arbeidsherverdeling in de bouw komt weinig terecht omdat er door arbeidsongeschiktheid steeds minder oudere werknemers van de VUT gebruik kunnen maken en verder omdat het uittreden gemakkelijk te beinvloeden is (met de VUT-voorwaarden), maar het herbezetten van de vrijgekomen arbeidsplaatsen niet. Schattingen van Mirkin (1987) lopen van 25\% herbezetting van vrijgekomen arbeidsplaatsen (Nederland) tot $95 \%$ (Frankrijk). Wat de Nederlandse situatie betreft is de VUT dus een weinig effectief middel tot herverdeling van arbeidsplaatsen. 
Wat is er karakteristiek voor VUT-regelingen? Volgens Blom (1983) het volgende:

- beëindiging van de dienstbetrekking,

- uitkering afhankelijk van het laatstverdiende loon,

- vrijwilligheid,

- een minimale bindingsduur aan bedrijf of bedrijfstak en

- het aanvullend karakter van de VUT, nl, alleen als er geen andere loondervingsregeling (sociale verzekering, pensioen, af vloeingsregeling) is.

Blom geeft ook een reeks gebreken in de VUT-regelingen: niet uniform, want per CAO geregeld, geen effectief toezicht op de uitvoering, zwakke rechtspositie van uitgetredenen, een VUT-breuk vergelijkbaar met de pensioenbreuk en achterstelling van groepen werknemers (zoals deeltijdwerkers) die wel meebetalen, maar geen aanspraken hebben.

Hesemans (1988) schetst enkele ontwikkelingen van de VUT-regeling; de gemiddelde VUT-gerechtigde leeftijd is van 62.4 jaar in 1982 tot 61.0 jaar in $\rrbracket 987$. Het minimaal vereiste aantal dienstjaren binnen deze periode is in de particuliere sector 7.9 jaar, bij de overheid 8.3 jaar en de gesubsidiëerde/gepremieërde sector 4.5 jaar. Het vereiste aantal dienstjaren is in deze tijd niet veranderd. Verder geeft Hesemans informatie over het percentage werknemers dat werkzaam is in een organisatie met een VUT-regeling. Dat is vrijwel 100\% bij overheid en gesubsidiëerde/gepremiëerde sector en $76.2 \%$ bij de particuliere bedrijven. Bij deze laatste loopt dit percentage van $51.5 \%$ in de kleinste bedrijven (1-9 werknemers) tot $89.9 \%$ ( 100 of meer werknemers).

\subsubsection{Aantallen verwroegd uitgetredenen}

Gegeven het karakter van de VUT is een volgende vraag, hoeveel werknemers van VUT-regelingen gebruik maken. Het aantal lopende gevallen bij het ABP werd al aangegeven in tabel 1.1; het is opgelopen van ruim duizend in 1981 tot drieëndertigduizend in 1986 (ABP, 1987). De aantallen nieuwe gevallen per jaar zijn in drie sectoren sinds 1984 gellopen zoals aangegeven in tabel 2.4 . 
Iabel 2.4. Wheuwe WT-gevel len per jaar in duizendtal llen*

\begin{tabular}{lcccc}
\hline jaar & particulier & trendvolgers & overheid & totas \\
\hline 1984 & 11 & 2 & 6 & 19 \\
1985 & 16 & 4 & 6 & 26 \\
1986 & 18 & 3 & 7 & 28 \\
1987 & 20 & 4 & 7 & 31 \\
\hline
\end{tabular}

* mondellinge opgave CAS, 1987 voorlopige cilfers

Zeker bij de particuliere bedrijven en de trendvolgers is een stijging aanwezig in het jaarlijks aantal toetredingen. Deze stijging is misschien duidelijker te zien in de cijfers van Bolhuis e.a. (1987), zie tabel 2.5 .

Iabel 2.5 Lopende aantall en wuT-gerechtigden per jaar in duizendtal L en*

\begin{tabular}{lccc}
\hline Jaar & bedrijuen & overheid & total \\
\hline 1981 & 18.3 & 3.6 & 21.9 \\
1984 & 30.3 & 17.8 & 48.1 \\
1985 & 36.9 & 23.7 & 60.6 \\
1986 & 45.0 & 29.0 & 74.0 \\
1987 & 53.1 & 33.8 & 86.9 \\
1990 & 73.8 & 42.0 & 115.8 \\
\hline
\end{tabular}

* Ramingen VuT-model CPB, (Bolhuis e.a., 1987)

Bolhuis e.a. merken op dat de stijging in de eerste plaats komt door de verlaging van de VUT-leeftijd in de jaren, dus door een verandering aan de aanbodkant. Dat van dat aanbod zo massaal gebruik wordt gemaakt is een bewijs voor de populariteit van de VUT.

\subsubsection{Economische oorzaken van de VUT}

We zullen de VUT nu in een breder verband proberen te zien om de groei ervan te verklaren en de toekomst van de VUT nader te bezien. Vervroegde pensione- 
ring is geen specifiek Nederlands verschijnsel; een overzicht van de internationale situatie wordt gegeven door Olson-Frick $(1980,1985)$ en Mirkin (1987). De algemene economische kanten van de VUT worden belicht door Wolozin (1981). Volgens Wolozin is de algemene tendentie, werknemers steeds vroeger en vollediger te pensioneren. Dat zou samenhangen met een streven naar doelmatigheid in bedrijven, gevoed door een ideologie waarin als vanzelfsprekend wordt aangenomen dat oudere werknemers hun waarde verliezen en afgestoten mogen worden ('marginalisering'). De samenleving stelt hierop een premie, doordat de kosten van uitstoot niet op de onderneming drukken, aldus Wolozin. Ook Standing (1986) ziet vervroegde pensionering als deel van een brede tendentie tot marginalisering van de oudere werknemer. De vraag is hierbij wel, hoe dit te rijmen is met de onmiskenbare populariteit van de VUT (zie paragraaf 2.3.2.).

Odell (1970) heeft een andere opvatting. Dat er steeds meer gepensioneerden zijn is geen gevolg van een beleid (van overheid, werknemers of werkgevers), maar van een ontwikkeling in de economie. Door de welvaart is het mogelijk meer gepensioneerden te onderhouden of ze eerder met pensioen te laten gaan. Ook Odell stelt dat de pensionering (al dan niet vroeg) niet gedwongen is, omdat de werknemers er graag gebruik van maken.

Sommige publicaties leggen verbanden tussen VUT en arbeidsongeschiktheid. De Galan (1980) en Van den Bosch \& Petersen (1982b) zien WAO/AWW en VUT als concurrerende regelingen; hoe meer werknemers in de ene regeling, hoe minder in de andere. Nijhuis \& Soeters $(1982$, p.178) tonen aan dat dit op bedrijfsniveau wel voor het vrouwelijk uitvoerende personeel geldt, maar niet voor het mannelijk uitvoerend of indirect ondersteunend personeel. Bij deze twee groepen werknemers hebben VUT en arbeidsongeschiktheid een aanvullend karakter. Van den Bosch \& Petersen (1982b) zien hierbij een relatieve daling van het aantal WAO-ers in de oudste groep werknemers sinds 1979. De Galan (1980) ziet in de VUT verder een middel om de arbeidsongeschiktheid in te dammen, als de arbeidsmarkt dat toestaat. Casey (1987) laat zien dat ook internationaal geldt dat de verschillende regelingen voor vervroegd uittreden en arbeidsongeschiktheid in elkaar overlopen, zodat ze elkaars functie kunnen overnemen. 
Kerkhoff e.a. (1987) legt verband tussen VUT en lage kwaliteit van de arbeid. Bij de heersende snelle technologische verandering raakt de ervaring van oudere werknemers snel verouderd en wordt door het bedrijf de VUT aangewend (ongeacht kosten voor individu en samenleving) om de ouderen te verwijderen en zo een bedrijfsprobleem op te lossen. Philipsen (1979) stelt, dat oudere werknemers er recht op hebben, op een passend tijdstip uit te treden en dat jongere werknetivers het reeht hebben, tot de beroepsbevolking toe te treden. Binnen de zwakke economie zou dat alleen mogelijk zijn bij arbeidstijdverkorting. Voor de oudere werknemers stelt hij voor, 60 jaar als "breukpunt" te nemen; daarna zouden werknemers kunnen vertrekken of in overleg aangepaste werkzaamheden kunnen aanvaarden.

Kijkt men naar de ontwikkelingen in de bevolkingsopbouw en de kosten die de VUT meebrengt, dan zou deze wel eens opgeheven moeten worden. Uit prognoses van het CBS (1982b) blijkt dat het aantal inwoners van 65 jaar en ouder tot het jaar 2025 groter zal worden dan het aantal economisch actieven van 64 jaar en jonger. Het CBS (1985) geeft verder cijfers over de kosten van de VUT in de laatste jaren. Van 1982 tot 1984 zijn die reeds opgelopen van $f 534$ miljoen tot $f 1.000$ miljoen. De werkgevers- en werknemersbijdrage zijn in drie jaar ongeveer verdubbeld, waarbij het aandeel van de VUT in de uitgaven voor de sociale verzekeringen steeg van $0.7 \%$ in 1982 tot $1.2 \%$ in 1984 .

Op grond van de ontwikkeling in het aantal ouderen en de toename wan de uitgaven voor de VUT voorspellen sommige auteurs dat de VUT in moeilijkheden zal raken en herzien zal moeten worden. Dit is althans de conclusie van Lutjens \& Wessels (1987), Van Koningsveld en Van Ginneken (1988) en voor de Amerikaanse situatie van Clark (1988). Daartegenover wijst het Centraal Economisch Plan (Centraal Planbureau, 1987) op de grote overschotten bij de pensioenfondsen. Daarmee zou volgens het Centraal Planbureau een algemene verlaging van de pensioenleeftijd kunnen worden betald, en als deze verlaging maar ver genoeg wordt doorgevoerd, (gesteld dat de reserves van de pensioenfondsen daarvoor toereikend zijn) komt de VUT vanzelf te vervallen. Er zijn dus verschillende opvattingen over het vervroegd wittreden en de enige conclusie die hier getrokken kan worden is, dat de toekomst van de VUT onzeker is. 


\subsubsection{Kenmerken van toetreders tot de VUT}

Hieronder komen de vragen aan de orde wie er van de VUT gebruik maken en waarom men besluit tot vervroegd uittreden. Barfield \& Morgan (1969) vonden in de Amerikaanse auto-industrie dat de werknemers massaal van een VUTregeling gebruik makten, zodra de mogelijkheid zich voordeed. Daarbij bleken overwegingen van een redelijk inkomen na het vertrek en van de gezondheid van het meeste belang te zijn. Werknemers met een slechte gezondheid waren het meest geneigd om te vertrekken.

Deze uitkomsten zijn later deels door anderen bevestigd. Quinn (1978) wond dat onaangenaam werk tot vroege pensionering disponeert, maar dat de gezondheid en het pensioeninkomen zwaar wegen in de uiteindelijke beslissing om met pensioen te gaan. Morrow (1982) bijvoorbeeld vond ook dat de inkomensverwachting van groot belang is en Kingson (1981a) liet zien dat dit deels een kwestie van scholling is; meer scholing leidt tot meer inkomen en een hoger ouderdomspensioen, zodat men meer vrijheid heeft om met werken op te houden. Een slechte gezondheid kan echter ook bij een grote verwachte achteruitgang in inkomen de doorslag geven (Riley e.a., 1972). Wan Santvoort (1982) kon in Nederland bevestigen dat het te verwachten inkomen de grootste invloed op de VUT-keuze heeft, gevolgd door overwegingen van arbeidsbelasting en gezondheid. Morse \& Gray (1980) wezen erop, dat er bij de VUT-keuze vaak een dilemma tussen inkomen en gezondheid optreedt.

Of de gezondheid altijd zo zwaar weegt is de vraag. Onderzoek bij Hoogovens (1979) wees uit dat er geen verschillen in verzuim in de voorafgaande vijf jaar waren tussen werknemers die direct, pas na enige tijd of niet van de VUT gebruik maakten. Van Koningsveld e.a. (1978) konden weinig verschillen tussen wel- en niet-uittreders vinden, behalve dat de uittreders hun werk zwaar waren gaan vinden. Schmitt \& McCune (1981) vonden dat gezondheid en demografische kenmerken een veel geringere invloed hebben op de VUT-beslissing dan het actuele en het verwachte inkomen. De Dienst Sociaal-Wetenschappelijk Onderzoek (1979) kon evenmin invloed van de gezondheidstoestand op de VUT-beslissing vinden in het onderwijs; belangrijker bleek onder meer het oordeel van de omgeving van de betrokkenen te zijn of het verstandig zou zijn, met de VUT te 
gaan. In een onderzoek door Van der Horst (1988) bleek de VUT-groep zowel subjectief als objectief een relatief gezonde groep te zijn (net als werkenden en werklozen, maar anders dan arbeidsongeschikten die een duidelijk slechtere gezondheid hebben). Draaisma e.a. (1989) vonden dat de uitvoerders in de bouwnijverheid die met de VUT vertrekken een groep van gezonde 'overlevenden' wit deze beroepsgroep vormen.

Soms wordt niet de gezondheid, maar de keerzijde: de zwaarte van of stress in het werk genoemd (zie Van Gageldonk, 1978; Dienst Sociaal-Wetenschappelijk Ondlerzoek, 1979; Jacobson, 1972; Kingson, 1981b en McGoldrick \& Cooper, 1985). Bijzonderheden daarbij zijn dat degenen die zich overbelast voelen, niet willen minderen maar ophouden met werken (Kloosterhuis-Duinker, 1979), en dat de functiehoogte met de werkdruk te maken heeft. Kloosterhuis-Duinker (1979) en Taylor (1979) vonden bij de overheid dat de stress toeneemt met de functiehoogte. Bij fysiek zware functies is weer het probleem dat ze niet aan de werknemer aangepast kunnen worden (Sheppard, 1976), terwijl de werknemer zich niet aan de functie aan kan passen. Er is dus zowel bij hoog- als bij laaggekwalificeerd werk druk om met de VUT te gaan.

Ook worden wel andere motieven in de literatuur aangetroffen. Kimmel e.a. (1978) vonden bijv. als redenen om met de VUT te gaan: nog van het leven willen genieten, lang genoeg gewerkt hebben en dus recht hebben op rust. Leyssen (1980) kon vaststellen dat ontevredenheid met het werk die in eerder periodiek geneeskundig onderzoek was vastgesteld, kenmerkend was voor de meeste later uitgetredenen. Philipsen \& Halfens (1983) konden echter bijna geen verschillen tussen wel- en niet-uitgetredenen vinden, behalve een wat laag medicijngebruik in de VUT-groep, wat kan wijzen op een gezondheidsmotief. De Rijks Psychologische Dienst (1983) vond bij een enquête onder VUT-gerechtigden (anders dan Kloosterhuis-Duinker, 1979) geen relatie tussen animo voor uittreden en functiehoogte. Bij de latere VUT-gangers bleek mee te spelen dat zij vinden, lang genoeg gewerkt te hebben en dat men plaats wil maken voor jongeren. Howard (1988) vond in een onderzoek onder leidinggevenden in een bedrijf geen verschillen tussen wel- en niet vroeg uitgetredenen in bekwaamheid of prestaties. Wel bleek er verschil in wat zij 'retirement proneness' noemde, bij de VUTgroep een betrekkelijk lage werkmotivatie, weinig behoef te aan zekerheid door 
het werk en weinig financiële beletsels. Kortom, weinig aantrekking door het werk, gecombineerd met weinig afstoting door het vooruitzicht, niet meer te zullen werken.

Proberen we de verschillende standpunten samen te vatten, dan blijkt de rol van de gezondheid in de VUT-beslissing niet steeds even duidelijk te zijn. In sommig onderzoek is verminderde gezondheid een reden om vroeg wit te treden, in ander onderzoek blijken de vervoegd uitgetreden een groep "gezonde overlevers" te zijn. Andere factoren dan de gezondheid, vooral het verwachte inkomen, blijken een minstens zo belangrijke rol als de gezondheid te spelen.

\subsection{Ontslagname}

\subsubsection{Wettelijk kader van ontslagname}

De formele spelregels voor het ontslag zijn, wat de Nederlandse situatie betreft, vastgelegd in het arbeidsovereenkomstrecht als deel van het arbeidsrecht (Knaapen, 1980). De overeenkomstige regels voor het ontslag van ambtenaren zijn te vinden in het Arbeidsovereenkomstenbesluit (Van Haren, 1980). Het initiatief tot ontslag kan zowel aan werknemers- als aan werkgeverskant liggen. Hier zal slechts één kant daarvan belicht worden en wel ontslag op verzoek van de werknemer (zie paragraaf 1.2).

\subsubsection{Motieven woor ontslagname}

Waarom nemen werknemers ontslag? Een antwoord wordt gegeven door de Arbeidskrachtentelling wan het CBS (1982a), waarin een overzicht wordt gegeven van de motieven van degenen die ander werk zoeken. Hieruit blijkt op de eerste plaats, dat $5 \%$ van de mannen en $6 \%$ van de vrouwen op een willekeurig moment ander werk zoeken, een cijfer dat afneemt van $9 \%$ in de groep tot 24 jaar tot $1 \%$ bij de boven-vijftigjarigen. Dit gaat om werkenden die nog geen ander werk gevonden hebben. Alleen van degenen die hun laatste werkkring beëindigd heb- 
ben (dus een heel specifieke groep) levert dezelfde telling een overzicht van de motieven woor het vertrek (tabel 2.6).

Tabel 2.6 Percentuele verdeling van redenen warom werkzokenden (niet werklozen, scholieren of studenten) hun latste werkkring beëlindigden

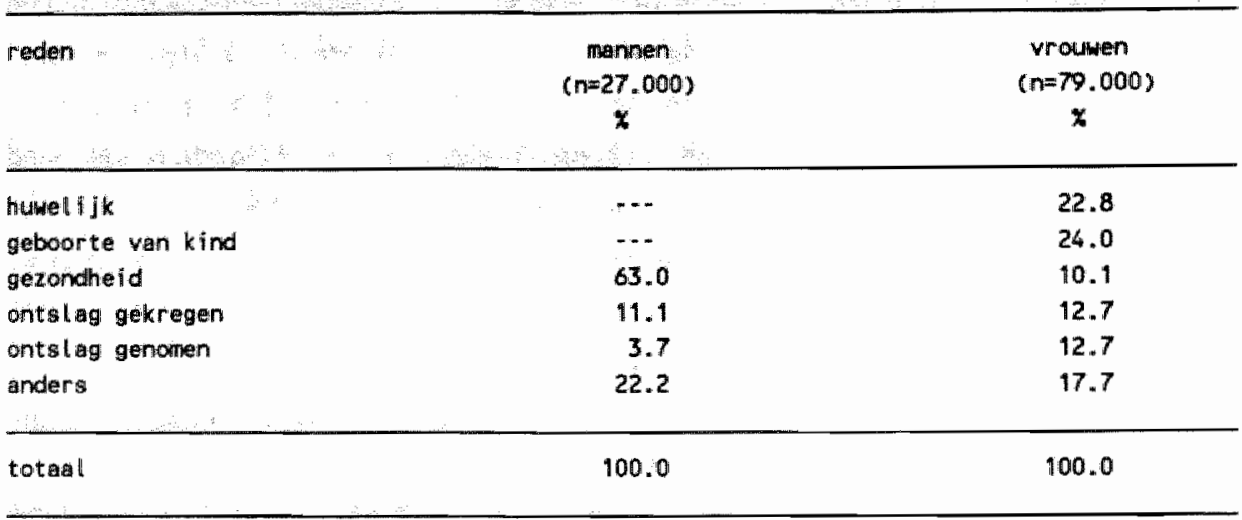

bron: Arbeidskrachtentelling 1979; CBS, 1982a

Bij de rubriek 'ontslag genomen' is helaas geen informatie over de reden waarom men ontslag nam. Verder zijn er grote verschillen tussen de beide geslachten: bij de mannen staan gezondheidsredenen duidelijk voorop; bij de vrouwen zijn de motieven meer gespreid, en daarbij zijn de belangrijkste motieven huwelijk en geboorte van kinderen. Bij het uitvoerders-onderzoek in de bouwnijverheid van Draaisma e.a. (1989) bleek, dat gevoelens van overbelasting en verminderde gezondheid ook binnen deze beroepsgroep meespelen bij het zoeken en aanvaarden van ander werk.

\subsubsection{Aggregatieniveau bij ontslagname/verloop}

Ontslagname kan zowel een individueel- als een groepskenmerk zijn, en het zou verschil kunnen maken in de kracht van de voorspelling, of de gegevens individueel dan wel groepsgebonden zijn. Nicholson e.a. (1977) spreekt het vermoeden uit dat de samenhangen soms zwak zijn omdat het onderzoek niet kijkt naar afzonderlijke werknemers, maar naar grotere organisatorische eenheden (afdeling, bedrijfsvestiging). Binnen zo een eenheid zouden de details verloren gaan en daarmee zou de voorspellende kracht werminderen. 
Het is de vraag, of dit juist is. Een studie waarin beide niveaus (zowell de individuele werknemer als de werkeenheid) worden beschouwd is die van Price \& Mueller (1986) over ontslagname in een aantal ziekenhuizen. Binnen een groot aantal variabelen als inogelijke voorspellers werden er op individueel niveau enkele gevonden die met latere ontslagname samenhangen, namelijk de uitspraak naar een andere werknemer te willen, de geïntegreerdheid van de werknemer in de organisatie, de duur van het dienstverband en het al eerder van werknemer veranderd zijn. De overige eenendertig variabelen bleken nauwelijks iets aan de voorspelling bij te dragen (de verklaarde variantie was bijna 13\%). Een voorspelling in hetzelfde materiaal op het niveau van de werkeenheid (operatiekamer, laboratorium, fysiotherapie etc.) bereikte vrijwel dezelfde waarde (15\% verklaarde variantie), waarbij echter geen van de onafhankelijke variabelen op zichzelf een goede voorspeller bleek te zijn.

Price \& Mueller zijn een recent voorbeeld, waaruit op te maken valt, dat de voorspelling van ontslagname zwak is en dat het daarbij niet veel uitmaakt of men zich richt op individuen of op groepen werknemers.

\subsubsection{Modellen van ontslagname en verloop}

De literatuur over ontslag en verloop heeft een zo grote omvang, dat het hier alleen mogelijk is, chronologisch een aantal overzichtsartikelen op dit terrein te presenteren. Dit zall gebeuren aan de hand van de overzichten uit de afgelopen ruim vijftien jaar, namelijk van Porter \& Steers (1973), Mobley e.a. (1979), Bluedorn (1982a), Cotton \& Tuttle (1986) en Van Breukelen (1989). Hiermee kan een idee worden gegeven van de ontwikkeling van het denken over ontslag in de loop van de jaren. Bovendien zal aandacht worden gegeven aan twee meer gespecialiseerde overzichtsartikelen, namelijk Rhodes (1983) over de invloed van de leeftijd en van Steel \& Ovalle (1984) over die van de gedrags-intenties van werknemers op ontslag en verloop. 


\section{Porter \& Steers (1973)}

Porter \& Steers (1973) bezien het verloop vanuilt vier gezichtspunten: organisatiegebonden factoren, de invloed van de directe werkomgeving, de takinhoud en persoonlijke factoren.

Bij de organisatiefactoren staan beloning en bevordering op de voorgrond, waarbij niet zozeer de loonhoogte of de snelheid van promoties gelden, maar de gepercipieërde billijkheid daarvan. Het laatste in termen van de verhouding van de verwachtingen en de subjectieve inbreng in het werk.

Wat betreft de invloed van de directe werkomgeving op de beslissing te vertrekken, noemen Porter \& Steers als belangrijkste factor de aanvaardbaarheid van de stijl van leidinggeven, de grootte van de werkeenheid (hoe groter, hoe meer verloop), en de tevredenheid over de collega's.

Ontevredenheid met de takinhoud, -duidelijkheid, -werantwoordelijkheid en zelfstandigheid zouden alle bijdragen aan de neiging ontslag te nemen. De persoonsgebonden factoren in het verloop zijn aldus nog steeds Porter \& Steers vooral leeftijd (hoe ouder, hoe minder verloop) en diensttijd (hoe langer in dienst, hoe minder verloop). Daarnaast werden persoonlijkheidstrekken zoals angst, emotionele instabiliteit, aggressie, onafhankelijkheid, zelfvertrouwen en ambitie genoemd als voor ontslagname predisponerende factoren.

Mobley e.a. (1979)

Mobley e.a. (1979) biedt een overzicht van ontwikkelingen sinds het artikel van Porter \& Steers uit 1973. De gevolgde indeling is naar persoonsgebonden factoren, arbeidstevredenheid, organisatie en werkomgeving, taakinhoud, arbeidsmarkt, beroepsgroep en enkele nieuwe factoren die toen net geëxploreerd werden.

De persoonsgebonden factoren zijn leeftijd, diensttijd, geslacht, verantwoordelijkheid voor een gezin en opleiding. Leeftijd en diensttijd hebben weer allebei een negatief verband met verloop. Wat betreft geslacht en opleidingsniveau wordt geen duidelijke conclusie getrokken; gezinsverantwoordelijkheid hangt negatief met vertrek samen. 
De globale arbeidstevredenheid heeft bij Mobley e.a. een remmende invloed op het verloop. $\mathrm{Zij}$ tekenen er echter bij aan, dat het verband tussen de globale tevredenheid en het verloop niet sterk is.

Bij de organisatie- en werkomgevingsfactoren onderscheidt Mobley e.a. beloning en bevordering, tevredenheid met de leiding en de relaties met collega's. Bij beloning en bevordering spelen zowel hun niveau als de relatie tot de verwachtingen van de werknemer een rol, en daardoor is er geen duidelijke relatie tussen enerzijds loon en promoties en anderzijds verloop. De tevredenheid over de leidinggevenden heeft daarentegen een zwak negatief verband met verloop, terwijl er geen verband is tussen verloop en tevredenheid over collega's (het laatste vermoedelijk doordat mensen verschillen in hun behoefte aan sociale contacten).

Factoren, gelegen in de taakinhoud waren ten tijde van het artikel van Mobley e.a. in opkomst. De eerste aanwijzingen werden gevonden voor negatieve relaties tussen tevredenheid met het werk zelf en verloop.

De invloed van arbeidsmarkt, dus de aanwezigheid van alternatief werk, wordt door Mobley e.a. als een doorslaggevende variabele gezien, anders dan bij Porter \& Steers (1973) die er geen melding van maken. Het onderzoek ten tijde van Mobley e.a. gaf echter nog geen mogelijkheden om tot duidelijke empirisch gefundeerde conclusies te komen. Dit geldt ook voor onderzoek van de relatie beroepsgroep-verloop en naar enkele toentertijd nieuwe factoren, zoals de intentie ander werk te zoeken, inzet ('commitment') en betrokkenheid ('involvement') in het werk.

\section{Bluedorn (1982a)}

Ons derde overzichtsartikel valt drie jaar later dan Mobley e.a., het gaat om Bluedorn (1982a) dat meer theoretisch georiënteerd is dan de twee voorafgaande overzichten. Bluedorn onderscheidt vier onderzoekstradities op het gebied van vrijwillige ontslagname die hij probeert onder brengen in één model. De vier tradities zijn de causale modellen van verloop volgens Price (1977) en volgens Mobley (1977), de verklaring van verloop uit inzet in de organisatie (Porter e.a, 1974) en de verwachtingstheorie van Vroom (1964). 
Het model van Price (1977) stelt, dat verschillende aspecten van het werk leiden tot een globalle graad van tevredenheid met het werk. Is die tevredenheid maar laag genoeg, dan kan dat leiden tot ontslagname, mits de arbeidsmarkt gunstig is, d.w.z. mits zich ander werk voordoet. Bluedorn kent een andere rol aan de situatie op de arbeidsmarkt toe, hij stelt dat die situatie samen met de werkaspecten de tevredenheid bepalen (kansen op de arbeidsmarkt zouden een werknemer dus meer ontevreden maken) en dat, zodra de arbeidstevredenheid laag genoeg is, de werknemer ontslag neemt.

In thet model van Mobley (1977) worden door de werknemer achtereenvolgens zeven fasen doorlopen. Geringe tevredenheid met het werk leidt tot het overwegen van ontslagname; dit op zijn beurt tot een evaluatie van al dan niet ander werk zoeken. Valt die evaluatie uit ten gunste van ander werk, dan zal de werknemer eerst de wens koesteren, ander werk te zoeken, waarna zoekactiviteiten volgen. Deze leiden tot een aantall alternatieven die geẻvalueerd worden, waarna in de laatste fase de beslissing valt, wel of geen ander werk te nemen. Bluedorn herleidt dit tot een eenvoudiger model: ontevredenheid - zoeken - afwegen van blijven of vertrekken - feitelijk blijven of vertrekken.

De derde stroming die Bluedorn behandelt is het onderzoek over de relatie tussen inzet voor de organisatie en ontslagname. Die inzet kan worden omschreven als de sterkte van de identificatie van een individu met zijn organisatie en de theorie stelt (uiteraard) dat er een negatief verband is tussen inzet en wrijwillig ontslag.

Bluedorn"s laatstgenoemde stroming is die, gebaseerd op de verwachtingstheorie van Vroom (1964). Aan het huidige werk en aan de alternatieve betrekkingen kan een werknemer een aantal kanten onderscheiden (bijvoorbeeld beloning, zelfstandigheid, afwisseling, etc.) die elk in zekere mate door die werknemer verwacht worden; tegelijk heeft elk van die aspecten een bepaalde waarde voor de werknemer. De aantrekkelijkheid van één aspect van een baan wordt bepaald door het produkt van de mate van verwachtheid en de waarde van dat aspect. De globale aantrekkelijkheid van de ene of de andere baan nu wordt bepaald door de som van die produkten over alle aspecten. Toegepast op ontslagname betekent 
dit (weer: uiteraard), dat de werknemer die baan prefereert die alles bij elkaar het meest aantrekkelijk is, en dat kan zijn huidige werk zijn of ander werk.

Wat zegt nu het geïntegreerde model van Bluedorn? Demografische kenmerken (zoals ethniciteit, geslacht, leeftijd, opleiding, tijd in dienst etc.) bepalen zowel de verwachtingen die de persoon heeft als de kansen die hij krijgt op de arbeidsmarkt. Deze beide, samen met de subjectief ervaren organisatie (mate van centralisatie, formalisatie, technologie, communicatie, conflicten etc.) determineren de arbeidstevredenheid. Geringe tevredenheid leidt via lage inzet voor de organisatie, zoeken van ander werk en het voornemen ontslag te nemen tot ontslagname, voor zover de arbeidsmarkt dit toelaat.

Een toetsing van precies dit model is niet voorhanden; van een bijna gelijk model wel, namelijk in Bluedorn (1982b). Daaruit blijkt dat ondanks alle theoretische verfijning de ontslagname voor het overgrote deel onverklaard blijft. Eén mogelijke verklaring hiervan is, dat de ontslagname misschien niet zo rationeel verloopt als het model wil. Anders gezegd: misschien is ontslagname in veel gevallen een impulsieve daad, die zich met de gebruikelijke onderzoeksmethoden niet laat vastleggen. Een andere mogelijke verklaring is, dat het model de ontslagname uit antecedente factoren wil verklaren, terwijl het heel goed mogelijk is, dat niet deze de doorslag geven, maar de voorstelling die de werknemer heeft van de attracties van de nieuwe baan. Een derde mogelijkheid is, dat ontslagname meer met de fase van de carrière dan met iets anders te maken heeft, en dus niet goed uit het huidige of het toekomstige werk verklaard kan worden (zie voor een overzicht van carrière-onderzoek Driver, 1988).

\section{Cotton \& Tuttle (1986)}

Cotton \& Tuttle (1986) bieden een literatuuroverzicht aan, tezamen met een 'meta-analyse', dat wil zeggen een schatting van de ware verbandlen op grond van uitkomsten van andere onderzoekingen. Cotton \& Tuttle concluderen dat de conclusies van eerdere owerzichten voor een groot deel bevestigd worden. Leeftijd, tijd in dienst, loonhoogte en globale tevredenheid met het werk bleken weer betrouwbare negatieve verbanden met ontslagname te hebben. Andere variabelen (repetitiviteit van de tak, toegang tot de arbeidsmarkt, intelligentie) vertoonden geen duidelijke samenhang met ontslagname. Cotton \& Tuttle vinden ook ver- 
banden die afwijken van wat in eerdere overzichten gevonden werd: de aanwezigheid van een vakbond in de organisatie en de loonhoogte verlagen het verloop, intelligentie van de werknemers verhoogt het. Verder blijken er veelbelovende variabelen te zijn zoals valdoen van het werk aan de verwachtingen, plannen tot ontslagname, en inzet voor de organisatie.

\section{Van Breukelen (1989)}

Het laatste overzichtsartikel over personeelsverloop is van Van Breukelen (1989), dat weer meer conceptueel van aard is (vergelijk Bluedorn, 1982a). Hij concludeert dat economische factoren tot nu toe betere verklaringen van het verloop hebben opgeleverd dan individuele factoren (leeftijd, tijd in dienst, geslacht, opleiding, burgerlijke staat), werkgerelateerde factoren (werkinhoud, werkomgeving, organisatiekenmerken), arbeidstevredenheid en inzet voor de organisatie. Een centrale rol in de verklaring van het verloop wordt door Van Breukelen bij de economische factoren aan de arbeidsmarkt toegekend.

\section{Rhodes (1983)}

Een overzicht van publikaties over leeftijdsgebonden verschillen in werkattitudes en -gedrag is te vinden in Rhodes (1983). Wat betreft personeelsverloop wordt, net als in de overige hier vermelde bronnen, geconcludeerd dat er een overtuigend negatief verband tussen leeftijd en verloop is; hoe hoger de leeftijd, hoe minder werknemers over ontslagname denken en hoe lager het verloop is.

\section{Steel \& Ovalle (1984)}

Steel \& Ovalle (1984) voerden een meta-analyse uit op de literatuur over de relatie tussen verloopintenties en feitelijk verloop (zie voor de definitie van metaanalyses de passage over Cotton \& Tuttle eerder in deze paragraaf). $\mathrm{Zij}$ vonden dat er vier voorspellers van verloop zijn, in volgorde van minder sterk naar sterker: globale tevredenheid met de baan, tevredenheid met de werkzaamheden, betrokkenheid in de organisatie en de intentie van ontslagname. Dit zijn blijkbaar determinanten van ontslagname die een zekere waarde bewezen hebben.

\section{Conclusie}

Onze samenvatting met betrekking tot de ontslagname kan aansluiten bij Van Breukelen (1989). Hij signaleert in zijn evaluatie dat de kennis van het verloop- 
proces nog erg verbrokkeld is, en dat dit gebrek met voorrang zou moeten worden opgeheven. Hierbij zou men kunnen voortbouwen op het model van Mobley (1977; zie hiervoor, Bluedorn, 1982a). Het belangrijkst voor ons is de conclusie, dat er bij ontslagname nog vele onbekende factoren meespelen.

\subsection{Conclusies uit de literatuur: werkhypothesen}

Herhaald moet worden wat in de inleiding van dit hoofdstuk (paragraaf 2.1) al vermeld werd: het onderhavige onderzoek is niet gericht op de toetsing van hypothesen, maar op instrumentontwikkeling, d.w.z. in de eerste plaats op de ontwikkeling van een voorspellingsmethode voor uitval uit het werk en in de tweede plaats op de validering van de gebruikte vragenlijst, de VAG. De relatie tussen de literatuur en dit onderzoek is zwak doordat de gegevens niet ten behoeve van hypothesetoetsing verzameld zijn. De behandelde literatuur dient als achtergrond om de bestudeerde vertrekwijzen (arbeidsongeschiktheid, vervroegd uittreden en ontslagname) en daarmee als steun bij de instrumentontwikkeling en validatie.

\subsubsection{Conclusies over arbeidsongeschiktheid}

De meest algemene informatie uit de arbeidsongeschiktheidsliteratuur is de volgende. De meeste arbeidsongeschikten zijn oudere handarbeiders in niet-leidinggevend werk. Een veel voorkomend probleem en misschien een oorzaak van de arbeidsongeschiktheid is de arbeidsinspanning (lichamelijk of geestelijk) die bij onvoldoende herstelmogelijkheden tot een afname van de arbeidscapaciteit leidt. Dit gaat samen met een toename in de gezondheidsproblemen en het verzuim, en kan uiteindelijk tot arbeidsongeschiktheid leiden. Er speelt echter ook een proces van autonome, van het werk onafhankelijke achteruitgang mee. Bovendien zouden de sociale en organisatorische werkomgeving, net als de fysieke werkomstandigheden een bijkomende rol in dit proces kunnen spelen; de problemen thiermee zouden moeten toenemen met stijgende leeftijd.

De eerste conclusie, dus de eerste werkhypothese is dat de werknemers die later arbeidsongeschikt zullen worden in alle opzichten (of het nu gaat om gezondheid, 
werk of werkomstandigheden) meer problemen zullen hebben dan de niet-arbeidsongeschikten. De tweede werkhypothese is dat dit ook bij de verzuimgegevens tot uiting moet komen, nl. meer verzuim (hoger percentage, langere duur, hogere frequentie) bij de later arbeidsongeschikten in vergelijking met de nietarbeidsongeschikten.

Eerder werd al het onderzoek van Astrand e.a. (1988) genoemd. $\mathrm{Zij}$ concludeerden, dat werknemersuitspraken weinig met latere arbeidsongeschiktheid te maken hebben. Men kan zich afvragen of dat niet aan thun keuze van vragen of hun onderzoekssituatie ligt, dus of hun conclusie geen voorbarige generalisatie is. Dit wordt met het onderhavige onderzoek getoetst. De vraag is, of de werknemersmeningen die met de VAG gevraagd worden (zie paragraaf 3.6 en 3.7 , bijlage 1 en 2) wèl voorspellende waarde hebben. Dat is om twee redenen van belang, in de eerste plaats vanwege de vraag of in het algemeen werknemersmeningen bruikbaar zijn voor de voorspelling van arbeidsongeschiktheid en in de tweede plaats of die meningen, gemeten met de VAG een praktische voorspelling mogelijk maken.

\subsubsection{Conclusies over vervroegd uittreden}

We kunnen met Schmitt e.a. (1979) vaststellen dat de meeste argumenten voor verschillen tussen wel- en niet vervroegd uitgetredenen in motivatie of houding niet duidelijk of overtuigend zijn. Uit de literatuur is alleen duidelijk dat een ongunstige verhouding tussen belasting en belastbaarheid in het werk soms op de voorgrond stat en dat het verwachte inkomen na uittreden een belangrijke factor is. Over dit laatste zijn geen gegevens voorhanden. In het materiaal is dus verschil te verwachten in de arbeidsbelasting. Deze kan tot uiting komen in hoge somscores en daaraan gepaard veel verzuim bij de VUT-groep in vergelijking tot de niet-VUT-gangers. 


\subsubsection{Conclusies over ontslagname}

Wat valt er in de literatuur ten aanzien van ontslagname te vinden, dat weerspiegeld zou moeten worden in de onderzoeksgegevens? De aangetroffen relaties zijn zwak en de verschillende auteurs spreken elkaar nogal eens tegen. Er is alleen duidelijk dat het om een betrekkelijk jonge groep werknemers gaat. Wat betreft de variabelen: er worden er geen uitgesloten door de literatuur. Bij zowel werknemersmeningen (met name de werkvariabelen) als verzuimgegevens kunnen zwak positieve verbanden verwacht worden, d.w.z. een hogere kans op latere ontslagname als er meer problemen zijn (op welk onderwerp dan ook) en naarmate het verzuim (frequentie of percentage) hoger is. De verwachtingen op grond van de literatuur ten aanzien van ontslagname zijn dus zeer globaal. 
Hieronder wordt als overzicht eerst kort aangegeven, welke gegevens er voor het onderzoek verzameld zijn, uit welke bedrijven deze afkomstig zijn en hoe ze verwerkt zijn. In dit hoofdstuk wordt verder beschreven wat de eigenschappen van de persoons- en functiekenmerken zijn (paragraaf 3.4). Vervolgens komen van de verkllarende variabelen de verzuimgegevens aan de orde (paragraaf 3.5 ), gevolgd door de enquêtegegevens (de lange VAG-vragenlijst in paragraaf 3.6 en de korte VAG in paragraaf 3.7 ), gevolgd door de conclusie wat betreft de verklarende variabelen. Daarna worden de te verklaren variabelen nl. de vertrekwijzen (arbeidsongeschiktheid, vervroegd uittreden en ontslagname) behandeld (paragraaf 3.9 en 3.10). Tenslotte (paragraaf 3.11 ) wordt als logische schakel met de resultatenhoofdstukken (hoofdstuk 4 en 5) aangegeven welke bewerkingen er op de variabelen zijn toegepast.

$B i j$ de persoons- en functiekenmerken (paragraaf 3.4) gaat het om exploratie: welke van die kenmerken moeten we nemen, welke kunnen we weglaten? Bij de verklarende variabelen (waarvan we hopen dat het echte voorspellende variabelen zullen blijken te zijn) ligt het accent verschillend. De verzuimgegevens worden op hun representativiteit getoetst door vergelijking met cijfers van de NIPG-verzuimstatistiek (NIPG/TNO, 1990). Bij de werknemersmeningen is het in de eerste plaats belangrijk, te weten of de afzonderlijke vragen uit de VAG een voorspelling van vertrek mogelijk maken. Dit blijkt niet te kunnen; daarom is vervolgens de kwestie hoe de vragen uit de lange VAG tot bredere, en onvermijdelijk abstractere, somscores samengevoegd kunnen worden (paragraaf 3.6.1 3.6.4). De vraag is daarbij, wat de betrouwbaarheid en validiteit van die somscores is. Het blijkt dat er uit de somscores twee brede indices samen te stellen zijn, die worden beschreven in paragraaf 3.6.5. Paragraaf 3.7 is gewijd aan de korte versie van de VAG en de eigenschappen daarvan. De indeling van deze paragraaf loopt parallel aan de voorafgaande, dus weer de betrouwbaarheid en validiteit van de korte VAG (paragraaf 3.7 .2 - 3.7.4) en de splitsing van de VAG-kort in twee indices (paragraaf 3.7.5). 
Omdat de gegevens nooit helemaal los staan wan de bedrijven waar ze verzameld ziljn, volgt eerst een korte karakterisering van de bedrijven. Voor het onderzoek is met deze organisaties afgesproken dat zij anoniem voor derden blijven, zodat hier hun identiteit niet vermeld kan worden. In plaats daarvan kunnen wel hun algemene kenmerken worden vermeld, zie tabel 3.1 .

Tabel 3.1 Belangrijkste kemerken wan de vier bedrijwen

\begin{tabular}{|c|c|c|c|c|}
\hline bedrijf & A & B & c & D \\
\hline sector & particulier & overheid & particulier & overheid \\
\hline aard & drukkerij & $\begin{array}{l}\text { technisch } \\
\text { onderhouds- } \\
\text { bedriff }\end{array}$ & drukkerij & $\begin{array}{l}\text { reini - } \\
\text { gings - } \\
\text { dienst }\end{array}$ \\
\hline \multicolumn{5}{|l|}{ antal } \\
\hline werknemers & $500-999$ & $1500-1999$ & $500 \cdot 999$ & $1000-1489$ \\
\hline \multicolumn{5}{|l|}{ WAGi- } \\
\hline onderzoeks jaar & 1978 & 1978 & 1979 & 1980 \\
\hline \multicolumn{5}{|l|}{ jaren wit- } \\
\hline tredegegevens & $1979-183^{*}$ & $1979-183$ & $1980-183$ & $1981-83$ \\
\hline \multicolumn{4}{|l|}{ jaren ver- } & $1978-181$ \\
\hline respons** & $74 \%$ & $79 \%$ & $79 \%$ & $7 \| x$ \\
\hline
\end{tabular}

* gegevens over ontslagname inclusief 1978, zie paragraaf 3.9.1

* percentage werknemers dat deelnam aan het VAGmonderzoek

\subsection{De respons bij het onderzoek}

In geen van de bedrijfsonderzoeken hebben alle werknemers deelgenomen aan het invullen van de vragenlijsten. De deelname, het percentage werknemers dat de vragenlijst beantwoordde, varieert van $7 \rrbracket \%$ tot $79 \%$ per bedrijf. De niet-deel- 
nemers bij een onderzoek als het onderhavige hebben volgens Dijkstra (1981) een frequenter of langer durend ziekteverzuim, of allebei. Dit zou kunnen samenhangen met 1) vrees voor oneigenlijk gebruik van de onderzoeksresultaten, waar wooral degenen met een hoog ziekteverzuim, uit vrees voor negatieve sancties, bang voor zouden zijn, of 2) aanwezigheid van marginale werknemers die zich niet verbonden voelen met het bedrijf, en wier non-participatie tot uiting komt in een hoog verzuim en niet-deelname aan het onderzoek. Dat betekent dat de schattingen van het verzuim en de aantallen klachten te laag (conservatief) zullen zijn en dat de verbanden tussen de variabelen (dus ook de voorspelling van uitval) zwakker zullen zijn dan in het ideale geval (bij 100\% deelname) zou worden gevonden.

\subsection{De gebruikte gegevens}

De te verklaren variabelen zijn (zie paragraaf 1.2 en 3.8 ):

- arbeidsongeschiktheid (WAO of invaliditeitspensioen),

- vervroegd uittreden (VUT) en

- vrijwillige ontslagname.

De verklarende variabelen zijn de vragenlijstgegevens uit de VAG, d.w.z. percentages problemen wan werknemers (paragraaf 3.6 ) en verder verzuimgegevens (zie paragraaf 3.5). De VAG peilt het oordeel van de werknemer zelf over diens arbeidssituatie en gezondheid, d.w.z. dat de VAG gericht is op thet 'persoonlijk functioneren' van de werknemer (Dijkstra e.a., 1981). Er is een uitgebreide versie van de VAG met 117 vragen (bijlage 1) en een korte versie met 40 vragen (bijlage 2). Beide zullen hier toegepast worden. De eigenschappen van de beide versies van de VAG komen aan de orde in paragraaf 3.6 en 3.7

Op grond van inhoudelijke overwegingen en factoranalytische uitkomsten zin binnen de VAG-lange versie zeven clusters vragen onderscheiden, die als somscores worden gehanteerd (zie figuur 3.1). Naast deze zeven deelscores wordt er bij de lange VAG uiteraard ook een totaalscore toegepast, terwijl voor het doel van het onderhavige onderzoek er twee indices samengesteld zijn, die respectievelijk vier somscores samenvatten. 
De korte versie van de VAG is een selectie van veertig goed discriminerende vragen. In een eerdere fase van de ontwikkeling van de VAG werden er acht i.p.v. zeven somscores onderscheiden (de somscore Inspanning was nog gesplitst in lichamelijke en meatale inspanning). Binnen elk van deze acht clusters vragen werden de vijf best discriminerende uitgekozen. Goed discrimineren wil bij deze vragen met twee antwoordcategorieèn zeggen: zo dicht mogelijk bij een 50/50verdeling.

Gezien de geringe voorspellende kracht van antwoorden op afzonderlijke vragen of 'items' zal alleen van somscores of percentages problemen gebruik worden gemaakt. Deze worden (zie paragraaf 3.6 voor de precieze argumenten) gehanteerd op drie niveaus, $\mathrm{nl}$. somscores die de vragen per onderwerp samenvatten, indices die groepen somscores weergeven en een totaalscore, zoals aangegeven in figuur 3.1 en figuur 3.2 .

Figuir 3.1 Items, somscores, indices en totaalscore van de VAG lange versie*

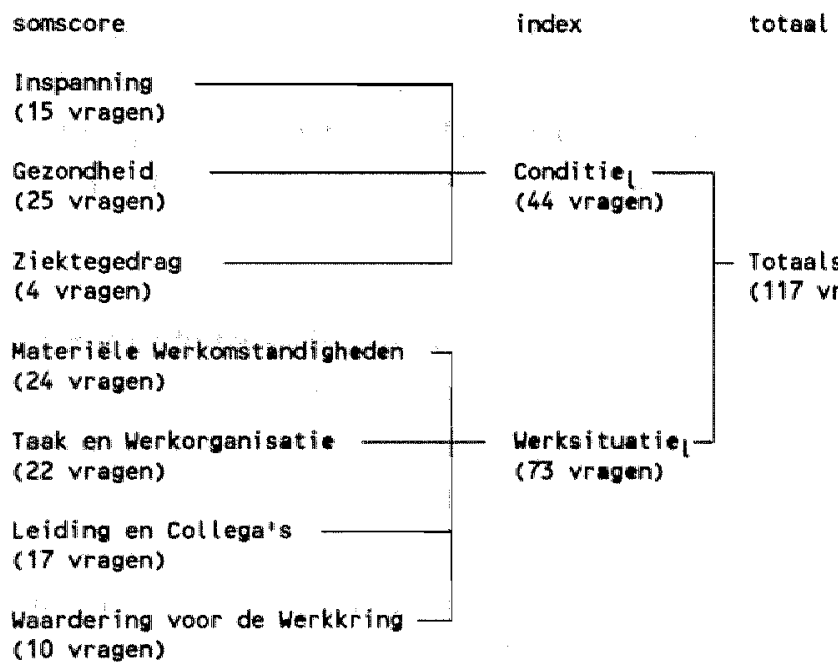

- Zie bijllage 1 en 3 voor de specificatie van de items. 
Naast de variabelen van figuur 3.1 zal ook een korte versie van de VAG met 40 vragen beproefd worden op zijn waarde als voorspeller van vertrek uit het werk. Ook de korte VAG kan worden gesplitst in twee indices, zie figuur 3.2.

\section{Eiguur 3.2 It tems en indices vari de VAG; korte versie*}

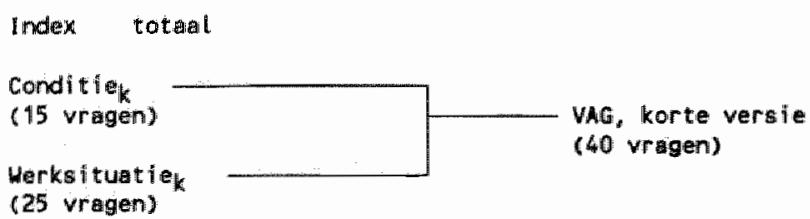

- Zie bijlage 2 en 4 woor de specificatie van de itens.

De scores en indices zijn gebaseerd op waarderende en niet op beschrijvende vragen; hun precieze opbouw en eigenschappen worden uiteengezet in respectievelijk bijlage 3 en 4 en paragraaf 3.7. Hier is het belangrijkste, dat elke score of index angeeft op hoeveel procent van de vragen binnen een onderwerp een werknemer een probleem meldde. De scores en indices zijn dus hoger naarmate iemand meer problemen met het betreffende onderwerp heeft. Overigens sluit het gebruik van deze brede scores als voorspellers niet uit dat er in de praktijk van een bedrijfssituatie ook naar afzonderlijke vragen gekeken wordt om de voorspelling te concretiseren.

De gebruikte verzuimcijfers zijn het verzuimpercentage en de verzuimfrequentie. Het verzuimpercentage geeft aan welk deel van de tijd een werknemer in een bepaald kalenderjaar afwezig is geweest. De verzuimfrequentie is zijn aantal verzuimgevallen in datzelfde jaar. Zie paragraaf 3.5 voor de details.

Door het zonder meer samenvoegen van de gegevens van de vier bedrijven zouden problemen kunnen ontstaan. Bijvoorbeeld het ogenschijnlijke onderscheid tussen hoog-en laagverzuimende individuele werknemers in hoofdstuk 4 en 5 zou in werkelijkheid neer kunnen komen op een verschil tussen bedrijven met een hoog respectievelijk laag verzuim, met als gevolg onjuiste interpretaties van de uitkomsten. Om die reden is een controle uitgevoerd op de toelaatbaarheid 
van de aggregatie van de gegevens (zowel de verklarende als de te verklaren variabelen) door middel van 'som-dispersiematrices'. Hierbij worden de te controleren variabelen onderling gecorreleerd op twee manieren, $n l$. a) door eerst op elke variabele een correctie voor de bedrijfsverschillen toe te passen en correlaties te berekenen tussen de gecorrigeerde variabelen en vervolgens b) door de correlaties te berekenen tussen de gegevens die samengenomen worden zonder deze correctie. Slechts dan mogen de gegevens zonder meer samengenomen worden, als de beide correlatiematrices (volgens methode $a$ en b) weinig verschillen vertonen.

Deze methode is voor elk van de vertrekwijzen (arbeidsongeschiktheid, vervroegd uittreden en ontslagname) toegepast op de variabelen Conditie, Werksituatie $_{\downarrow}$ en het verzuimpercentage. De resultaten hiervan zijn ter inzage bij de auteur. In alle gevallen bleken de correlaties pas in de tweede decimaal te verschillen. De conclusie is daarom, dat aggregatie van de gegevens zonder correcties toegestaan is. Er is afgezien van overeenkomstige berekeningen met de verzuimfrequentie, omdat ervan is uitgegaan, dat ook daarbij de verschillen zeer gering zullen zijn.

\subsection{Persoons- en functiekenmerken}

Naast verzuimcijfers en werknemersmeningen uit de VAG-enquete ter verklaring van vertrek (in de vorm van arbeidsongeschiktheid, VUT en ontslagname) zijn er ook gegevens die een af wijkende rol spelen en andere die misschien voor de hand liggen, maar die om verschillende redenen toch buiten beschouwing blijven. Dit laatste wordt eerst toegelicht, daarna wordt ingegaan op de eigenschappen van de gehanteerde variabelen.

De onderzoekswraag is gericht op individuele signalen van ongewenste uitval uit het werk; het gaat er niet in de eerste plaats om, groepen werknemers te onderscheiden die een afwijkende kans op uitval hebben. Daarom zijn persoons- en functiekenmerken niet als verklarende variabelen gebruikt, maar als indelingsprincipe om na te gaan of er binnen naar persoons- en functiekenmerken meer homogene groepen specifieke samenhangen op individueel niveau bestaan. Zo 
zijn er indelingen gemaakt naar leeftijd en geslacht, naar al dan niet leidinggewen en naar deel van de organisatie. De leeftijdsgroepen zijn meestal 16 - 34 jaar, 35 - 49 jaar en 50 jaar of ouder. Het CBS hanteert in de Sociaal-economische Maandstatistiek een indeling in elf leeftijdsgroepen $(15-19,20-24,25-29$, $30-34,35-39,40-44,45-49,50-54,55-57.5,57.5-59,60-64$ jaar); de aantallen aanwezige werknemers binnen het materiaal staat zo een fijne indeling niet toe, want er zouden vele lege cellen ontstaan. Om tot een grovere indelling te komen zijn grenzen gelegd bij 34/35 jaar wanneer werknemers een stabiele fase ingaan in hun carrière (zie Super, 1968) en bij 49/50 jaar, wanneer men tot de oudere werknemers gaat behoren. De indelling naar deel van de organisatie is naar produktie- en overige afdelingen (hoofd- tegenover hulpproces, direct- tegenover indirect produktieven), ontleend aan In 't Veld (1976).

Er zijn ook indelingscriteria die niet gebruikt worden. Deeltijdarbeid en ploegendienst komen in het materiaal betrekkelijk weinig voor; het aantal werknemers dat minder dan 38 uur per week werkt schommelt tussen $5.5 \%$ en $9.1 \%$ bij een total van $7.8 \%$. Het aantal ploegendienstwerkers varieert tussen $1.7 \%$ en $24.7 \%$ per bedrijf met een gemiddelde van $9.7 \%$. Stratificeert men werknemers naar deze kenmerken, dan zijn de resterende aantallen te klein om nog behoorlijke verbanden te kunnen verwachten. De kenmerken die wel gebruikt kunnen worden zijn leeftijd, geslacht, al dan niet leiding geven, inkomen en scholingsniveau. Dijkstra e.a. (1981) geeft de correlatie tussen deze vijf gegevens, zie tabel 3.2 .

Inbel 3.2 correlattes tussen persoons- en functiekenmerken wan werknemers wit wier bedrifuen * (ontleend aan Dljkstra e. . ", 1981)

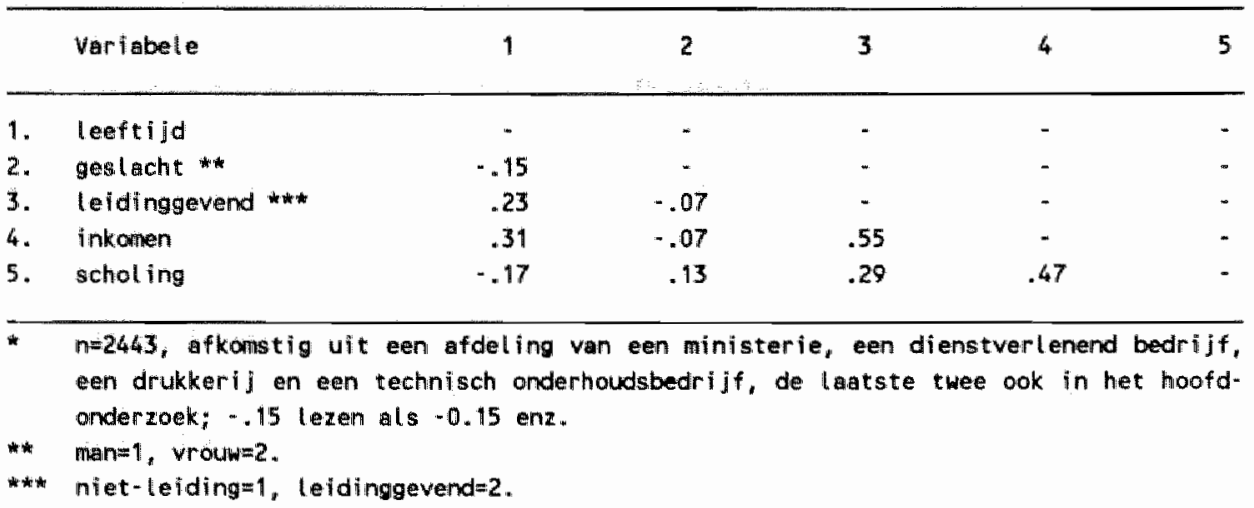


De drie correlaties rechtsonder $(.55, .29$ en .47$)$ geven aan dat al dan niet leiding geven, inkomen en scholingsniveau veel met elkaar te maken hebben; ligt eén van de drie vast, dan is de kans groot dat de andere twee al voor een flink deel bepaald zijn. Daarom is er een keuze gemaakt uit de variabelen die naast leeftijd en geslacht zullen worden gebruikt. Aangezien de scholing al lang geleden kan zijn en omdat in de relatie leidinggeven - inkomen het inkomen het gevolg is, is besloten inkomen en scholing te laten vervallen en alleen met al dan niet leiding geven rekening te houden.

Tenslotte nog een opmerking over de aantallen werknemers in de onderscheiden groepen. In bedrijf $B, C$ en $D$ werden de persoons- en functiekenmerken ontleend aan de bedrijfsadministraties, in bedrijf $A$ aan de werknemers zelf. Deze hebben niet steeds volledige gegevens vermeld" daardoor is niet bij elk persoonsof functiekenmerk hetzelf de aantal werkmemers ingedeeld. Er kunnen daardoor in de latere tabellen verschillen in de aantallen optreden.

\subsection{Verklarende variabelen: verzuimgegevens}

Bij het vaststellen van de verzuimcijfers zijn de definities van de verzuimstatistiek van het NIPG (1990) aangehouden. Verzuimgevallen worden gerekend in het jaar waarin ze eindigen, ook als ze in het jaar tevoren begonnen. Verzuimen die in thet beschouwde jaar beginnen, maar niet eindigen horen bij het volgende jaar. Er wordt verondersteld dat verzuimgevallen over de twee jaarwisselingen heen elkaar in evenwicht houden, zodat een correcte weergave wordt verkregen. De duur van de verzuimen wordt gerekend in kalenderdagen inclusief de dag van ziekmelding tot de dag van herstelmelding.

Smulders (1984a) onderscheidt drie verzuimmaten: het verzuimpercentage, d.w.z. het gemiddeld aantal verzuimde dagen per honderd kalenderdagen, de verzuimfrequentie of het gemiddelde aantal verzuimmeldingen per verzuimgeval, in kalenderdagen. Deze drie maten zijn niet onderling onafhankelijk, want het verzuimpercentage is evenredig met het produkt van de verzuimfrequentie en de gemiddelde duur, dus zijn twee van de drie maten bekend, dan ligt de derde vast. Er wordt om die reden alleen gerekend met VF en V\%. De beschikbare ge- 


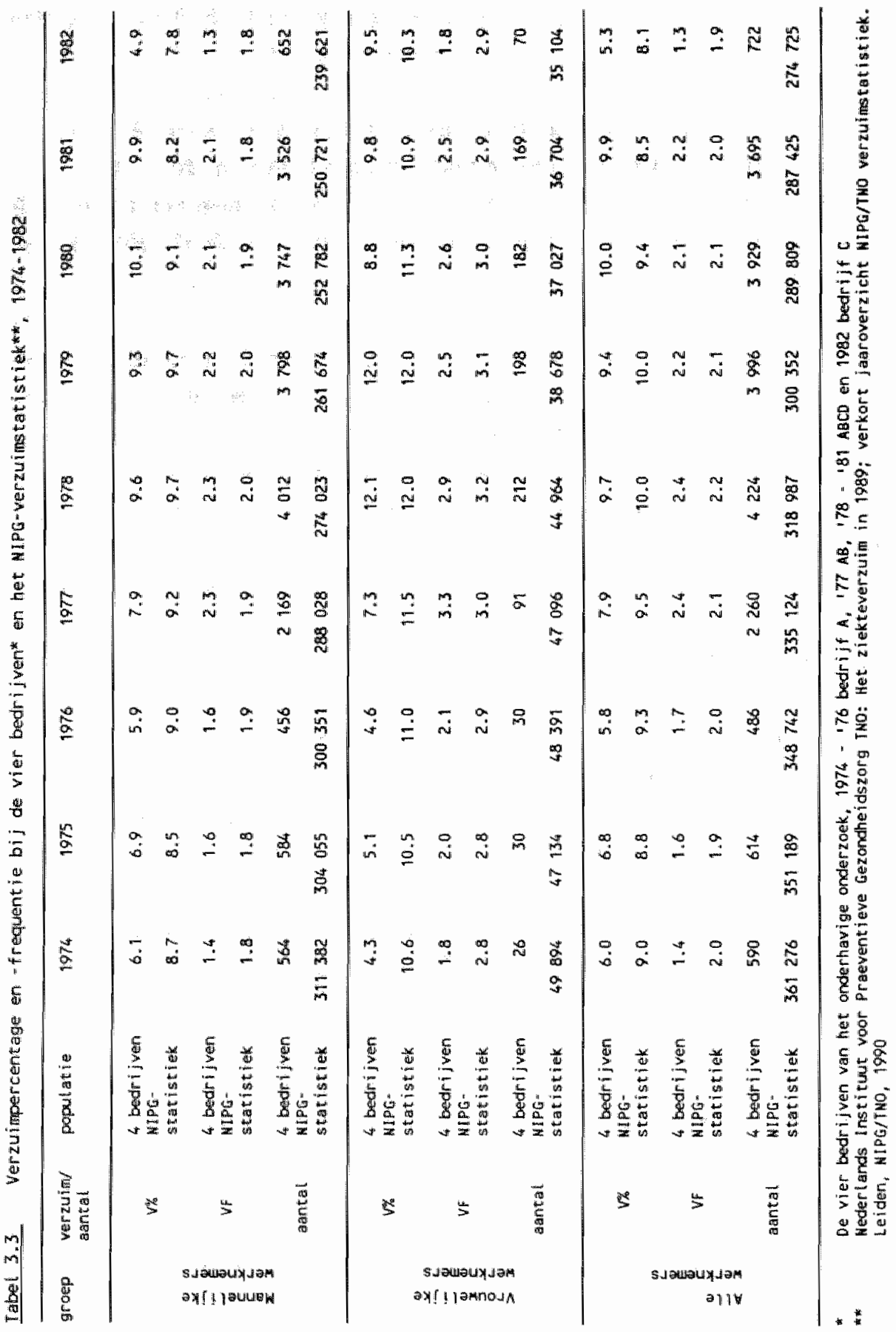


gevens worden weergegeven in tabel 3.3, vergeleken met de NIPG-verzuimstatistiek, over de periode 1974-1982.

De cijfers voor $V \%$ en VF van de vier bedrijven vertonen van nature meer fluctuatie dan die van de NIPG-verzuimstatistiek, doordat ze op kleinere aantallen werknemers gebaseerd zijn ; dit geldt zeker voor de jaren 1974-1977. Over de periode 1978-1982 zijn de aantallen in de vier bedrijven hoger en dan blijken de verzuimcijfers dicht bij die van de NIPG-statistiek te liggen.

Te concluderen valt:

1. dat de cijfers binnen de te verwachten waarden vallen en

2. dat latere verbanden tussen verzuim en vertrek uit het werk gegeneraliseerd mogen worden.

3.6 Verklarende variabelen: meningen over arbeid en gezondheid in somscores, VAG lange versie

De VAG lange versie telt 117 vragen; niemand kan die op één moment overzien, $e r$ is dus behoefte de vragen samen te vatten.

Het is vaak an te bevelen, in de uitkomsten van onderzoek dicht bij de oorspronkelijke gegevens te blijven, omdat zo die uitkomsten het best te interpreteren zijn. Voor dit onderzoek zou dat betekenen dat de afzonderlijke antwoorden op elke vraag van de enquête de voorkeur zouden verdienen boven scores op schalen die reeksen antwoorden samenvatten. Dit standpunt wordt ingenomen door Weitz \& Nuckols, 1955; Schuh, 1967 en De Jong, 1987. Een recent voorbeeld van gebruik van afzonderlijke antwoorden is Van der Putten e.a. (1989). Zij gebruikten naast diagnosen, functie- en demografische kenmerken ongeclusterde klachten van de werknemers als voorspellers van arbeidsongeschiktheid. De voorspellingen van al deze auteurs zijn zwak. De conclusie zou daarom kunnen zijn, dat afzonderlijke niet-geclusterde uitspraken wan werknemers in het algemeen weinig voorspellend vermogen inzake arbeidsongeschiktheid hebben. Het is echter de vraag of we voorspellingen van vertrek uit werk wel op losse uitspraken moeten baseren, en niet op clusters of samengestelde scores. 
Om de voorspellende waarde van afzonderlijke antwoorden respectievelijk somscores te schatten is in een eerder stadium van dit onderzoek de samenhang berekend van de best bruikbare vragen (bijlage 1) en van de somscores (paragraaf 3.6.1 en bijlage 3) met arbeidsongeschiktheid. Als criterium voor keuze van de vragen is genomen dat de wel- en niet-arbeidsongeschikten significant verschillen in het antwoord (zo niet, dan kan deze al heel weinig voorspellen).

Als bewerkingstechniek is stapsgewijze regressie genomen, als maat voor de verklarende kracht van de somscores is èta kwadraat gekozen. Bij stapsgewijze regressie wordt eerst de beste voorspeller gekozen, dan de op eén na beste, enz., tot en met de laatste. Bij elke stap wordt aangegeven hoeveel van het criterium 'arbeidsongeschiktheid" (welk percentage variantie) er verklaard wordt. Bovendien wordt aangegeven of de bijdrage van een stap statistisch significant is ( $p=$ 0.05). Tabel 3.4 geeft de resultaten van deze bewerkingen.

Er was een sterke beperking in de vragen, maar nu blijkt dat er maar vier vragen zijn die een significant deel van het arbeidsongeschiktheidscriterium verklaren. Bovendien verklaren deze tezamen slechts $5 \%$ van de totale variantie van de arbeidsongeschiktheid, een percentage dat met veel moeite na 23 stappen tot boven de $7 \%$ komt. De somscores verklaren echter met elkaar $18 \%$ van de variantie. 
Iabel 3.4 Stapsgewijze regressie van 23 geselecteerde vragen als voorspellers van arbeidsangeschiktheid onder mannen van 50-65 jaar $(n=863)$

\begin{tabular}{|c|c|c|}
\hline stap & variabele, korte inhoud & $\begin{array}{l}\text { cumulatieve } \\
\text { verklaarde } \\
\text { wariantive }\end{array}$ \\
\hline 1 & hinder werk door niet in orde voelen & $2.73 *$ \\
\hline 2 & bij arts geweest met klacht & 3.72 \\
\hline 3 & werkt geregeld over & $4.59 *$ \\
\hline 4 & moeite met ingespannen kijken & 5.45 \\
\hline 5 & werk is vaak te vermoeiend & 5.80 \\
\hline 6 & wordt behandeld voor rugklachten & 6.08 \\
\hline 7 & veel moeite met buigen en bukken & 6.27 \\
\hline 8 & kont gleregeld slaap tekort & 6.39 \\
\hline 9 & is vaak nerveus & 6.60 \\
\hline 10 & voelt zich valk gespannen & 6.66 \\
\hline 11 & waelt zilch vaak gejaagd & 6.77 \\
\hline 12 & is dikwijls prïkkellbaer & 6.83 \\
\hline 13 & stalat geregeld moe op & 6.87 \\
\hline 14 & wil het kalmer aen gaan doen & 6.91 \\
\hline 15 & heeft veel moeite met staan & 6.96 \\
\hline 16. & heeft de laatste tijd gezondheidsklachten & 6.99 \\
\hline 17 & klachten benen en voeten & 7.02 \\
\hline 18 & moei te werken in ongenakkeli jke houdingen & 7.03 \\
\hline 19 & veel moeite met tillen en sjouwen & 7.04 \\
\hline 20 & geregeld pijn onder in de rug & 7.05 \\
\hline 21 & werk is lichamel ijk erg vermoeiend & 7.05 \\
\hline 22 & heeft veel hinder wan lawaa i & 7.05 \\
\hline 23 & gezondheidsklachten toegeschreven an werk & 7.05 \\
\hline
\end{tabular}

* significant, $p \leq 0.05$

Er zijn geen redenen om te veronderstellen dat deze uitkomst bij andere vertrekwijze (VUT, ontslagname) en bij andere somscores (tabel 3.5) anders zou liggen. We gaan er om die reden van uit, dat de somscores voor ons doel veel bruikbaarder zijn dan de losse vragen. Daarom wordt er hier verder afgezien van losse vragen en wordt er alleen gebruik gemaakt van scores die samenvattingen zijn van antwoorden over een aantal aspecten van werk en gezondheid. 
Er moet blijkbaar van al te concrete details van de werksituatie worden afgezien om tot behoorlijke samenhangen met vertrek te kunnen komen, net zoals men bij het verzuim niet af moet gaan op éen verzuimgeval, maar op maten zoals verzuimpercentage en -frequentie die gebaseerd zijn op alle verzuimgevallen van iemand over een langere periode (meestal een jaar). Door optelling worden toevalsfluctuaties uitgemiddeld en ontstaat een behoorlijke schatting, of thet nu gaat om verzuim of over klachten over een aspect van werk of gezondheid.

Voor het samenstellen van enquete-uitspraken bestaan verschillende methoden, zoals cluster- en factorscores, scores op basis van item-restcorrelaties en cumulatieve (Guttman- en Mokken-) schalen, zie bijw. Swanborn, 1982. Het blijkt dat op verschillende manier samengestelde schalen vrijwel dezelfde informatie gewen. Wat dat betreft zijn ze gelijkwaardig en daarom hangt de keuze van de schaaltechniek af van het doel wan het onderzoek (Lazarsfeld, 1959; De Vos, 1980). Omdat andere schaaltechnieken minder direct te begrijpen zijn, is bij toepassing van de VAG steeds van somscores gebruik gemaakt, met het oog op gemakkelijke interpretatie in bedrijfssituaties (Dijkstra e.a., 1981). De vragen (bijlage 1 en 2) worden gebundeld per onderwerp (bijlage 3 en 4) en bij elk onderwerp wordt het aantal geuite problemen van de werknemer weergegeven als het percentage klachten. Om deze redenen zijn ook hier deze somscores toegepast. De basis voor de indeling in somscores is aangegeven in paragraaf 3.3: factorstructuur en inhoudelijke overwegingen hebben tot een indeling in zeven scores geleid (Dijkstra e.a., 1981 ).

Bijlage 3 en 4 geven in detail aan welke vragen welke somscores vormen. Tabel 3.5 geeft de globale betekenis van de verschillende gehanteerde somscores, inclusief de totaalscore (opgebouwd uit de zeven afzonderlijke somscores) en de korte versie van de VAG. Deze omvat veertig vragen die in één score worden samengevat; de waardering over de totale werksituatie ("Hoe goed zit u al met al met uw werk?", zie bijlage 2) telt in deze score niet mee. 
Iabel 3.5 Somscores wan de WAG, lange versie

\begin{tabular}{|c|c|c|}
\hline $\begin{array}{l}\text { benaming } \\
\text { somscore }\end{array}$ & betekenis & $\begin{array}{l}\text { aantal } \\
\text { wragen }\end{array}$ \\
\hline Inspanning & $\begin{array}{l}\text { Wichamelijke inspanning door werkhoudingen en } \\
\text { - bewegingen, mentale inspanning door onder meer } \\
\text { waarnemen en concentratie, gevolgen van inspan- } \\
\text { ning in termen van gezondheid }\end{array}$ & 15 \\
\hline Gezondheid & $\begin{array}{l}\text { uitspraken over uit teenlopende sezondhelds- } \\
\text { klachten, nerveuze klachten en slaapproblemen }\end{array}$ & 25 \\
\hline 2 li elktegedrag & $\begin{array}{l}\text { uitspraken over gebruik van medicijnen, be- } \\
\text { zoeken aan en behandel ingen door artsen, ver- } \\
\text { zuim volgens de werknemer }\end{array}$ & 4 \\
\hline Materiëlle & luchtklimaat, thawai en trillingen, ver- & \\
\hline Werkoms tandi gheden & $\begin{array}{l}\text { lichting en verontreinigingen op de werkplek, } \\
\text { inrichting van de werkplek. }\end{array}$ & 24 \\
\hline $\begin{array}{l}\text { Taak en Werk- } \\
\text { organisatie }\end{array}$ & $\begin{array}{l}\text { manier waarop de werkzaamheden georganiseerd } \\
\text { zijn, overleg en samenwerking, bruikbatrheid } \\
\text { en beschikbearheid van informatie, materiaal } \\
\text { en middelen }\end{array}$ & 22 \\
\hline $\begin{array}{l}\text { Leiding en } \\
\text { Collegal's }\end{array}$ & $\begin{array}{l}\text { onderlinge sfeer, wisseling van collega's em } \\
\text { leiding, manier van optreden van de leiding }\end{array}$ & 17 \\
\hline $\begin{array}{l}\text { Waardering voor } \\
\text { de Werkkring }\end{array}$ & $\begin{array}{l}\text { tevredenheid over de werkgever, ervaren bil- } \\
\text { lijkheid wan de behandeling en vooruitzichten } \\
\text { in het werk }\end{array}$ & 10 \\
\hline $\begin{array}{l}\text { Totaalscore, } \\
\text { VAG lange versle }\end{array}$ & alle waarderende uitspraken & 117 \\
\hline
\end{tabular}

De volgorde van de somscores verdient een opmerking. Een gebruikelijke indeling is die naar arbeidsinhoud, -omstandigheden, -woorwaarden en -verhoudingen. Deze wordt hier niet gevolgd omdat de eerste drie en de volgende vier scores twee indices vormen (zie paragraaf 3.6.5). Een volgorde, afwijkend van die hierboven zou verwarring geven. 


\subsubsection{Gemiddelde en spreiding van de somscores, VAG lange versie}

Een vraag is, of het geoorloofd is, op grond van de gegevens wan de vier bedrijven (zie paragraaf 3.1) latere uitkomsten te generaliseren naar de werkende bevolking. Een criterium daarvoor is, of de gemiddelden en spreidingen van de somscores in de vier bedrijven afwijken van bedrijven; zo ja, dan wordt generaliseren riskant. De andere organisaties hieronder zijn een deel van een ministerie, een culturele organisatie, een openbaar vervoersbedrijf, een reinigingsdienst, een constructiebedrijf en een waterleidingbedrijf. Tabel 3.6 geeft de cijfers.

Iabel 3.6 Percentages prablemen en standaardafwijkingen van zeven scores en de totalalscare van de VAG in de vier onderzochte bedrijuen en een referentiegroep van zes andere bedrijuen

\begin{tabular}{|c|c|c|c|c|}
\hline \multirow[b]{2}{*}{ soniscore } & \multicolumn{2}{|c|}{ percentage } & \multicolumn{2}{|c|}{ standaardaf wi jking } \\
\hline & bedri juen* & referent î & vier bedri jwen* & referentie** \\
\hline Inspanini ing & 16.7 & 13.3 & 17.9 & 16.1 \\
\hline Gezondheid & 19.2 & 18.4 & 18.8 & 18.4 \\
\hline 2 i ektegedrag & 37.5 & 35.0 & 32.2 & 31.3 \\
\hline \multicolumn{5}{|l|}{ Materiêl Werkomstandig- } \\
\hline heden & 23.3 & 25.4 & 19.4 & 19.6 \\
\hline Taak en Werkorganisatie & 20.9 & 20.5 & 15.2 & 14.0 \\
\hline Leiding en collega"s & 20.0 & 18.2 & 19.3 & 18.4 \\
\hline $\begin{array}{l}\text { Waerdering Werkkring } \\
\text { Totaslscore, }\end{array}$ & 24.0 & 22.0 & 22.3 & 20.5 \\
\hline WAG lange versie & 21.1 & 20.4 & 13.2 & 12.6 \\
\hline
\end{tabular}

$n=3486$

* $n=3065$

De cijfers van de vier bedrijven (zowel de percentages als de standaardafwijkingen) wijken over de hele linie weinig af van de zes andere bedrijven. Deze gegevens kunnen daarom zonder bezwaar gebruikt worden als basis voor verdere generalisatie, als tenminste voldaan is aan verdere eisen van betrouwbaarheid en validiteit: 
Voor de betrouwbaarheid bestaan verschillende criteria de interne consistentie of de gemiddelde samenhang, de correlatie tussen twee gelijkwaardige vormen van de meting, de samenhang tussen twee helften en de overeenkomst tussen twee af namen bij dezelfde personen ("test-hertest-betrouwbarheid') (Nunnally, 1967). Van de VAG bestaan geen gelijkwaardige vormen. De vragenlijst telt ongeveer tweehonderd vragen, waaronder de 117 waarderende vragen van bijlage 1, de overige zijn neutrale beschrijvende vragen. Door zijn lengte zijn gelijkwaardige vormen onpraktisch omdat een in lengte verdubbelde VAG niet in een bedrijf af te nemen is. Gelijkwaardige helften zijn niet te realiseren omdat elk werk- of gezondheidsaspect binnen het uur dat de afname gemiddeld duurt maar eenmaal aan de orde gesteld kan worden. Er resteren daarom twee methoden: test-hertest met een deel van de vragen om het tijdsbeslag te beperken en interne consistentie.

De interne consistentie hangt af van het aantal vragen en van de gemiddelde samenhang tussen de antwoorden. De interne consistentie, uitgedrukt in Cronbach's alpha is een maat voor de betrouwbaarheid. Tabel 3.7 geeft de warden van alpha voor elk van de somscores, per bedrijf en in totaal.

Tabel 3.7 Sonscores wan de lange WAG: interme consistentile (Cronbach's alpha)

\begin{tabular}{|c|c|c|c|c|c|}
\hline \multirow[b]{2}{*}{ sonscore } & \multicolumn{4}{|c|}{ bedrijt } & \multirow[b]{2}{*}{ totat } \\
\hline & $A$ & 8 & C & D & \\
\hline $\begin{array}{l}\text { Inspaning } \\
\text { Gezondheld } \\
\text { ziektegedrag }\end{array}$ & $\begin{array}{l}.70^{*} \\
.84 \\
.44\end{array}$ & $\begin{array}{r}.77 \\
.86 \\
.64\end{array}$ & $\begin{array}{l}.74 \\
.65 \\
.63\end{array}$ & $\begin{array}{r}.83 \\
.89 \\
.68\end{array}$ & $\begin{array}{l}.77 \\
.86 \\
.60\end{array}$ \\
\hline $\begin{array}{l}\text { Water iele Werkomstandigheden } \\
\text { Taak en Werkorganisat ie } \\
\text { Leiding en Collega's } \\
\text { Waardering voor de Werkkring }\end{array}$ & $\begin{array}{l}.78 \\
.68 \\
.77 \\
.77\end{array}$ & $\begin{array}{r}-86 \\
-74 \\
-81 \\
-73\end{array}$ & $\begin{array}{l}.84 \\
.72 \\
.80 \\
.74\end{array}$ & $\begin{array}{r}.84 \\
.79 \\
.86 \\
.76\end{array}$ & $\begin{array}{r}.83 \\
.73 \\
.82 \\
.75\end{array}$ \\
\hline 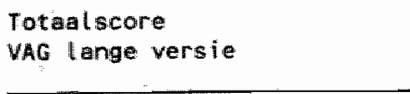 & .90 & .92 & .93 & .94 & .92 \\
\hline aratal werknemers & 585 & 1451 & 664 & 786 & 3486 \\
\hline
\end{tabular}

* te lezen ats 0.70 enz. 
Gerekend over het total van de vier bedrijven zijn alle alpha's 0.60 of hoger. Een waarde van 0.50 zou al aanvaardbaar kunnen zijn, omdat zo een score aan onze informatie bijdraagt (Guilford, 1954). Verder speelt het doel van de meting een rol bij de betekenis van alpha. Gaat het om selectie van personen, dan is een betrouwbaarheid wan 0.90 goed en eén van $0.80-0.90$ redelijk te noemen, maar voor theoretisch onderzoek is een lagere betrouwbaarheid aanvaardbaar (Visser e.a., z.j.). De naar verhouding zwakste score is Ziektegedrag, maar deze komt (behalve bij bedrijf $A$ ) met zijn consistentie boven de 0.60 , en alle andere somscores komen daar ver bovenuit. De totalscore kan zelfs voor selectiedoeleinden goed genoemd worden. Over het geheel zijn de interne consistenties van de somscores dus voldoende, zowel per bedri.jf als over het totaal.

Om de test-hertest-betrouwbaarheid vast te stellen is de korte versie van de VAG in verschillende organisaties (andere dan de hier behandelde vier, zie Dijkstra e.a., 1981) tweemaal afgenomen binnen een periode van rond de veertien dagen. De test-hertest-betrouwbaarheid bleek daarbij tussen 0.85 en 0.91 te liggen, zodat ook dit aspect van de betrouwbaarheid van de VAG alleszins aanvaardbaar is.

\subsubsection{Validiteit van de somscores}

Bij de validiteit of geldigheid van een meting is de vraag, of deze meet wat hij meten moet. Er worden meestal drie aspecten aan de validiteit onderscheiden (Nunnally, 1967): de predictieve validiteit, de inhouds- en de constructvaliditeit. Bij de predictieve validiteit is de kwestie of de meting een goede voorspelling van een extern criterium mogelijk makt. Voorspelling is het doel van dit onderzoek; in hoofdstuk 4 en 5 zal worden bezien of de somscores goede voorspellers van vertrek uit het werk blijken te zijn. Daarom blijft de predictieve validiteit hier buiten beschouwing.

In paragraaf 3.3 is het persoonlijk functioneren al gedefinieerd als het functioneren volgens de werknemer zelf (Dijkstra e.a., 1981) die zijn eigen maatstaven aanlegt aan de verschillende aspecten van zijn werksituatie en gezondheid. De methode van direct vragen aan de werknemer is daarbij de aange- 
wezen werkwijze, een argument voor de constructvaliditeit van de VAG. Een aanvullend argument daarvoor wat het gezondheidsdeel van de VAG betreft, wordt geleverd door Van der Horst (1988). Hij liet zien dat de subjectieve gezondheid, zoals gemeten met een panelonderzoek in de bevolking, overeenkomt met het het oordeel van artsen daarover blijkens medische dossiers.

Verder is de vraag of de wijze van samenstellen van de somscores door optelling van gemelde problemen, een juiste methode is. Bij de VAG heeft steeds eenvoud in het gebruik en begrijpelijkheid voor de gebruiker (de BGD, het bedrijf , de OR) voorop gestaan. Daarom is de eenvoudigste soort schaal gebruikt, ongewogen somscores (aantallen gemelde problemen per onderwerp per werknemer, eventueel uitgedrukt als percentages). De problemen krijgen allemaal hetzelfde gewicht, omdat aangetoond is, dat differentiele weging maar heel weinig aan de validiteit toevoegt (Parsons \& Hulin, 1982; Aamodt \& Kimbrough, 1985). Dit is thet tweede argument voor de constructvaliditeit.

De wraag bij de inhoudsvaliditeit is, of de aspecten die aan de orde worden gesteld een goed beeld geven van het functioneren. De inhoud van de VAG is mede gebaseerd op uiteenlopende bestaande vragenlijsten die het begrip' persoonlijk functioneren' raken en hieruit stap voor stap in een reeks bedrijven de uiteindelijke vorm ontwikkeld. Bij deze praktijkervaringen heeft de definitieve VAG bewezen weinig lacunes over te laten; er werd steeds gevraagd naar volgens de werknemers ontbrekende aspecten, een vraag die uiteindelijk geen nieuwe gezichtspunten meer opleverde. We mogen daarom aannemen dat de vragen en de daarop gebaseerde somscores (tabel 3.5) het begrip "persoonlijk functioneren' goed representeren, zodat de inhoudsvaliditeit goed is.

Er kan geconcludeerd worden dat de drie aspecten van de constructvaliditeit (vragen aan de werknemer, verwerking van ongewogen antwoorden tot somscores en dekking van het begrip 'persoonlijk functioneren') aan de maatstaven voldoen. 


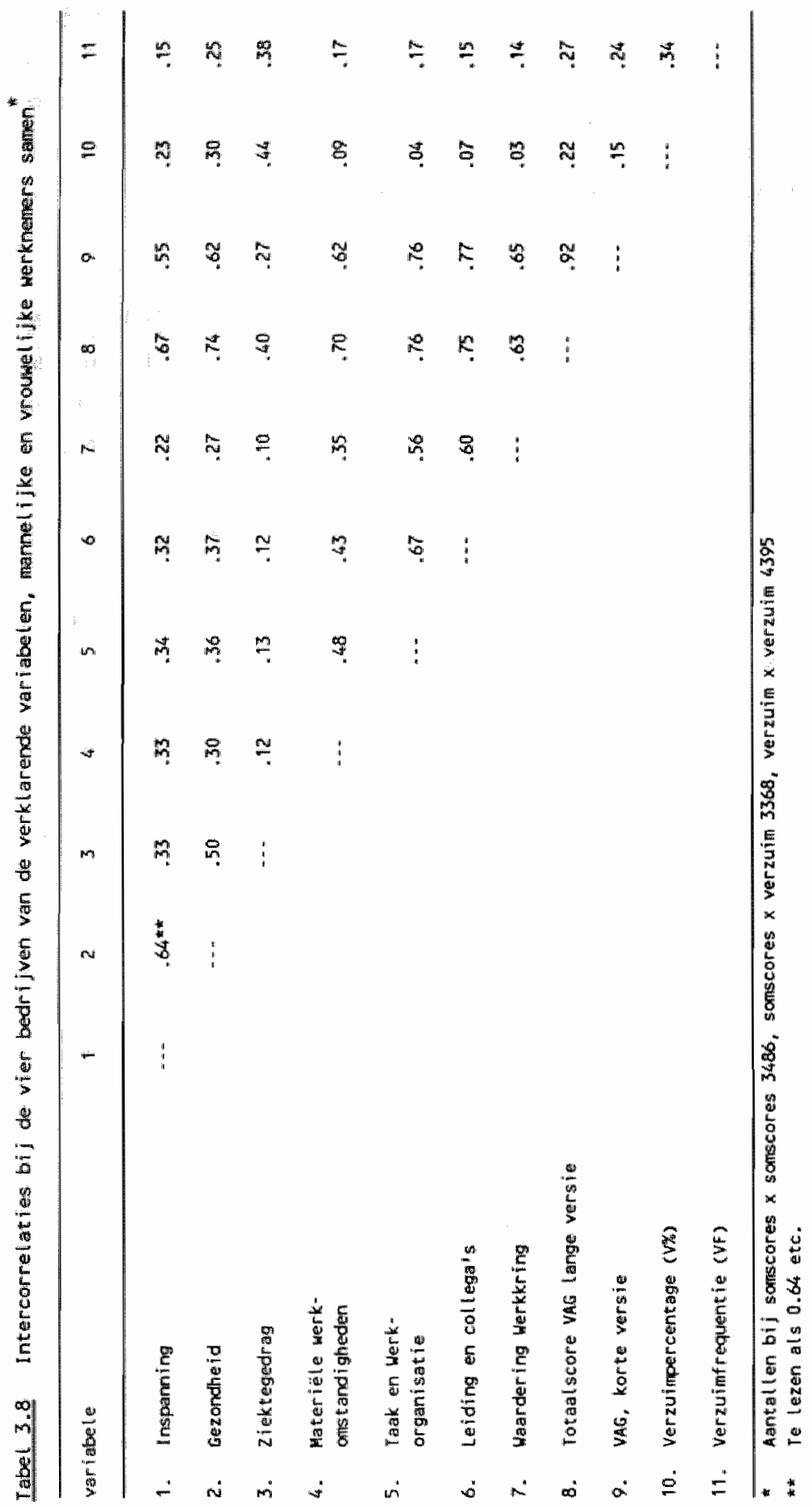




\section{Verbanden tussen de verklarende variabelen}

Een volgend aspect van de constructvaliditeit wordt gevormd door de relaties tussen de variabelen. De VAG wordt hier met zijn totaalscore en korte versie tegelijk met twee verzuimmaten gepresenteerd, om na te gaan welke verbanden er daartussen bestaan; zie tabell 3.8.

De totaalscore heeft sterke samenhangen met de afzonderlijke somscores $1 \mathrm{t} / \mathrm{m} 7$. Dit bewijst dat de totaalscore zijn rol als samenvatting van die afzonderlijke somscores goed vervult. De korte versie van de VAG geeft in doorsnee wat lagere correlaties. De oorzaak hiervan is dat de korte VAG met zijn 40 items minder informatie bevat dan de lange versie met 117 items. Dit neemt niet weg dat de correlatie tussen de totaalscore en de korte versie 0.92 is.

Een opmerking over de aard van deze samenhangen. De verbanden tussen de eerste zeven scores en de totalscore en tussen de laatste en de korte versie zijn correlaties tussen deel en geheel. Al deze samenhangen zijn sterk, maar ze zijn van andere aard dan de test-hertest-betrouwbaarheid en Cronbach alpha van paragraaf 3.6.3. De test-hertest-betrouwbaarheid bleek ongeveer 0.85 a 0.90 te zijn. Omdat dit van dezelfde orde van grootte is als de correlatie tussen korte versie en totalscore, kan vermoed worden dat ook de test-hertestbetrouwbaarheid van de totaalscore (die niet beschikbaar is, omdat hij door de grote lengte van de lijst niet te realiseren valt; zie eerder) ook aanzienlijk moet zijn.

\section{Verbanden tussen verklarende-, persoons- en functievariabelen}

Nog een kant van de constructvaliditeit is de samenhang van de scores met verdere gegevens die niet duidelijk externe criteria zijn, en die de rol van verstorende variabele ('confounder") zouden kunnen hebben. Ook uit de verschillen tussen bepaalde groepen werknemers kunnen aanwijzingen voor de validiteit worden gehaald. Voor de hand liggende indelingen zijn hier leeftijd en deel van de organisatie. De laatste is naar produktie- en overige afdelingen binnen de organisatie (zie In "t Veld, 1976). Wat betreft produktie- en overige afdelingen ligt het voor de hand, te verwachten dat de werknemers in de produktieafdelingen meer problemen zullen hebben met de fysieke werkomstandigheden dlan de overige afdelingen. Deze verwachting wordt getoetst aan de uitkomsten in het 
grootste materiaal dat beschikbaar is, n1. elf organisaties met in totaal 6543 werknemers.

\section{VAG: verschillen naar leeftijd}

Zoals blijkt uit een overzichtsartikel van Rhodes (1983) zijn sommige werknemersattitudes leeftijdsafhankelijk. Steeds blijkt dat de globalle tevredenheid met het werk toeneemt met stijgende leeftijd. De tevredenheid met sommige facetten van het werk zoals de beloning, de leiding en collega's hoeven echter niet leeftijdsgebonden te zijn. Wel is er bewijs, dat de betrokkenheid in het werk toeneemt met het ouder-worden, maar wat betreft de intrinsieke werkmotivatie en de inzet voor de organisatie is het niet zo helder. Hoewel er in het onderhavige onderzoek geen metingen van de tevredenheid of de betrokkenheid in het werk worden gebruikt, is toch te verwachten dat sommige variabelen leeftijdsgebonden zullen zijn. Zoals aangegeven in paragraaf 3.4 worden er drie leeftijdsgroepen aangehouden ( 17 - 34 jaar, 35 - 49 jaar en 50 jaar en ouder), een indeling die ook verderop, behalve bij de VUT gebruikt wordt.

Over het verband tussen leeftijd en gezondheidsklachten werden er twee opvattingen aangetroffen. Volgens de ene nemen met toenemende leeftijd de lichamelijke vermogens af en neemt het aantal gezondheidsproblemen toe (Lamberts, 1982; Honzik, 1984; Wilkins \& Adams, 1987). Te verwachten is hierbij, dat de aantallen klachten over inspanning, gezondheid en ziektegedrag met de leeftijd zullen toenemen, bij de andere onderwerpen ligt dit niet voor de hand. De andere opvatting is van Van der Zee (1982). Deze vond, dat vragenlijstscores over lichamelijke klachten soms weinig verband met de leeftijd hebben. Zijn verklaring hiervoor is, dat zulke scores uit twee componenten bestaan, namelijk slechte gezondheid en emotionele labiliteit. De eerste stijgt, de tweede daalt met toenemende leeftijd en in de score heffen de veranderingen in de twee componenten elkaar op.

De gemiddelde scores van de drie leeftijdsgroepen zijn aangegeven in tabe1 3.9 . 


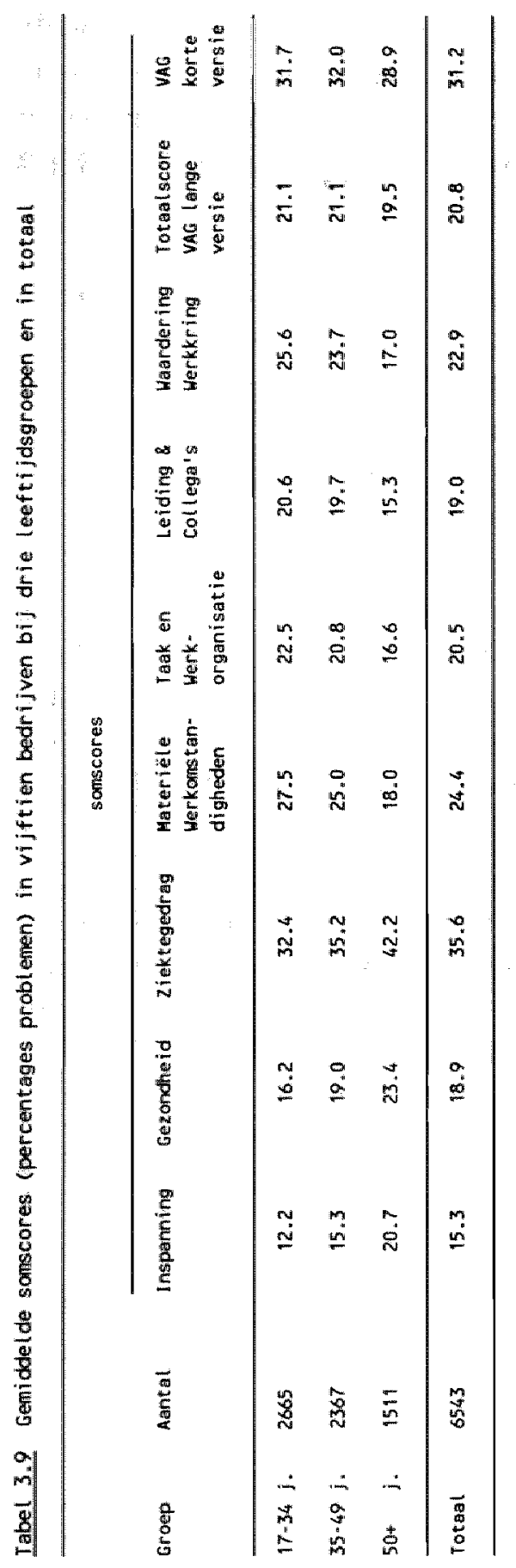


In overeenstemming met de eerstgenoemde verwachting nemen de aantallen klachten bij Inspanning, Gezondheid en Ziektegedrag toe met toenemende leeftijd. Wat echter niet verwacht werd (paragraaf 2.5.1), is dat de overige somscores (Materiële Werkomstandigheden, Taak en Werkorganisatie, Leiding en Collega's en Waardering voor de Werkkring) met toenemende leeftijd afnemen.

Dit betekent dat, vergeleken met de onvermijdelijk optredende achteruitgang in krachten en toename van lichamelijke problemen met stijgende leeftijd, de overige kanten van het werk hoger gewaardeerd worden; het laatste in de geest van Rhodes (1983). Deze tegengestelde verbanden heffen elkaar in de totaalscore en in de VAG-kort op, want deze twee scores verschillen weinig van elkaar over leeftijdsklassen.

\section{VAG: verschillen tussen typen afdeling}

Er worden (zie paragraaf 3.4 ) twee typen afdeling onderscheiden, nl. produktieen overige afdelingen en de onderstelling is, dat de fysieke werkomstandigheden in de produktieafdelingen slechter zullen zijn dan in de overige afdelingen. Dit verschil zal specifiek weerspiegeld moeten worden in de somscore Fysieke Werkomstandigheden, zie tabel 3.10.

In overeenstemming met deze onderstelling is de somscore Materiële Werkomstandigheden bij Produktie aanmerkelijk hoger (1.49 maal) dan bij Overig, terwijl de andere scores geen grote verschillen te zien geven (1.00 tot 1.17 maal). Dit pleit voor de validiteit van de somscore Materiële Werkomstandigheden. 


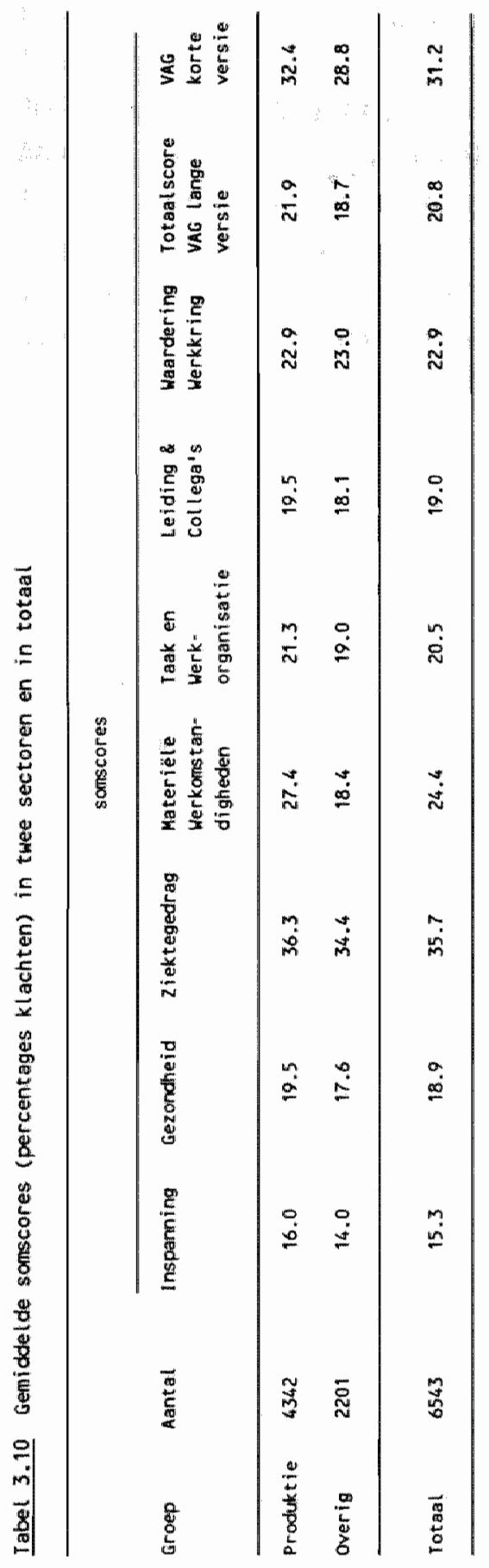




\subsubsection{Twee groepen somscores; indices lange versie}

Hiervoor bleek dat er twee groepen somscores zijn met tegengestelde leeftijdsrelaties: Gezondheid, Inspanning en Ziektegedrag die positief met leeftijd samenhangen en daarnaast Materiële Werkomstandligheden, Taak en Werkorganisatie, Leiding en Colllega"s en Waardering Werkkring die er negatief mee samenhangen. Ook bij het verzuim zou zoiets mogelijk zijn, want Smulders' ( $1984 \mathrm{~b}$ ) overzicht van de verzuimliteratuur laat zien dat verzuimfrequentie en -duur neigen naar negatieve resp. positieve samenhang met leeftijd. Daarom wordt in tabel 3.11 nagegaan wat binnen de vier bedrijven van het onderzoek de verbanden met leef tijd in het materiaal zijn.

Iabel 3.11 Correlaties van somscores en verzuimcijfers met leeftijd in de vier bedrijven*

\begin{tabular}{lc}
\hline \multicolumn{1}{c}{ wariabele } & correlatie** \\
\hline Inspanning & .18 \\
Gezondheid & .14 \\
Ziektegedrag & .12 \\
Materielle Werkonstandigheden & -.18 \\
Taak en Werkorganisatie & -.20 \\
Leiding en Collega's & -.15 \\
Waardering voor de Werkkring & -.18 \\
Total (score, VAG lange versie & -.07 \\
Verzuimpercentage (V\%) & .13 \\
Verzuimfrequentile (VF) & -.21 \\
\hline
\end{tabular}

- atantal bij de somscores 3486 , bij het verzuin 4395

** .18 te tezen als $0.18 \mathrm{enz}$.

De totalscore is bijna leeftijdsneutraal. Verder kloppen de twee groepen scores uiteraard met paragraaf 3.6 .4 en ze lopen samen met de twee verzuimmaten. Het verzuimpercentage heeft een positieve correlatie met leeftijd en zou bij de groep somscores Inspanning tot en met Ziektegedrag kunnen horen. De verzuimfrequentie heeft een negatieve correlatie met leeftijd en zou om die reden bij de groep Materiële Werkomstandigheden tot en met Waardering Werkkring kunnen worden gerekend. 
Cijfers als hiervoor spreken misschien minder dam grafieken. Daarom worden in figuur 3.3 - 3.5 de af zonderlijke somscores en de totaalscore grafisch tegen leeftijd uitgezet. Om de uiteenlopende variabelen op een gemeenschappelijke schaal te brengen en ze zo beter vergelijkbaar te maken zijn de gemiddelden per variabele (gerekend over alle werknemers) op honderd gesteld. Om een vloeiend beeld te krijgen zijn er voortschrijdende leeftijdsgroepen van vijf jaar samengesteld (19 - 23 jaar, 20 - 24 jaar, enz. $\mathrm{t} / \mathrm{m} 61-65$ jaar) ('moving averages', zie Wallis \& Roberts, 1963 en SPSS, 1985). Hierna zijn de waarden per leeftijdsgroep omgeschaald naar het totaalgemiddelde van 100 . Het resultaat is figuur $3.3 \mathrm{t} / \mathrm{m} 3.5$ (cijfers ter inzage bij de auteur).

Figuur 3.3 De somscores Inspanning, Gezondheid en Zlektegedragl en het werzuimpercentage met relatief gemiddelde 100 in woortschrijdende wijjaars leeftijdsgroepen (mannelijke en vrouwelijke werknemers samen*"

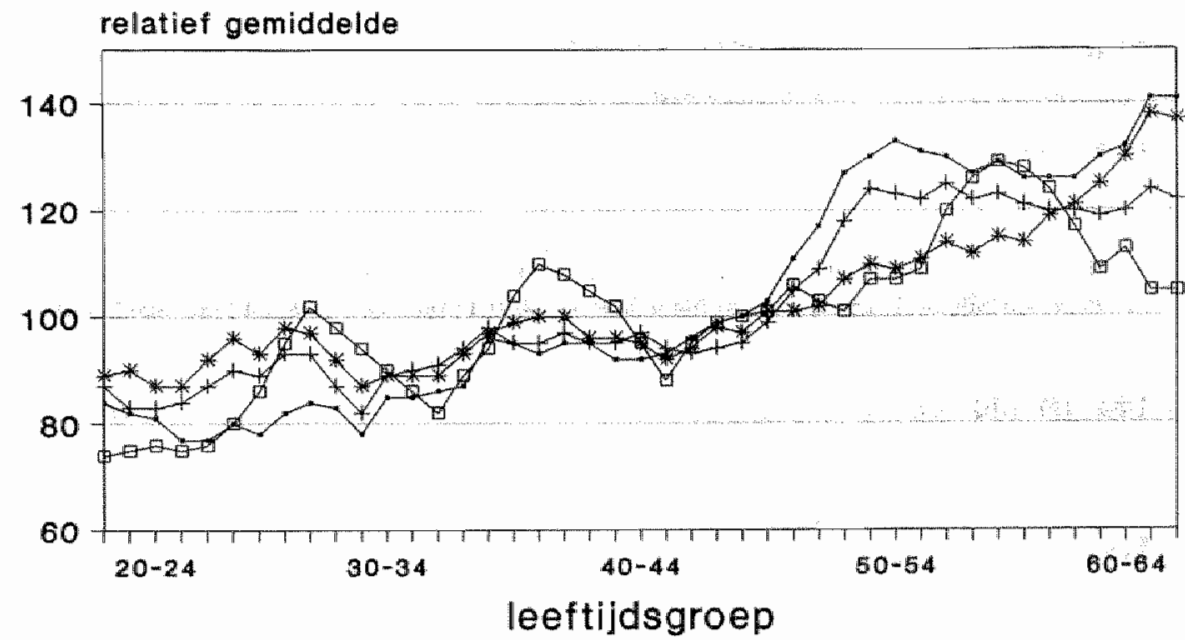
- Inspanning
-1- gezondhelld
- zlektegodrag
- - verzulmpercentage

- Iner groep 165-459 
Flgur 34 De somscores Wateritele Werkomstandigheden, Taak Werkorganisatie, Leiding "n Collega"s, Wardering Werkkring en de verzuimfrequentie met rellatief gemiddellde 100 in voortschrijdende wijfjaars leeftijdsgroepen (mannelijke en urousel ijke werknemers simenting

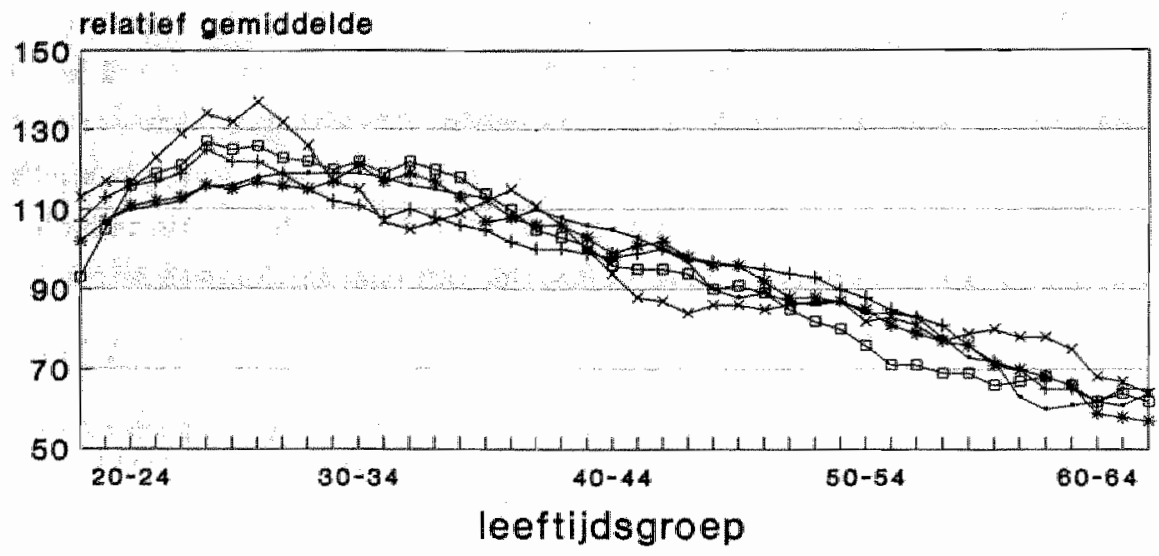

\footnotetext{
- mat.werkomst.heden - taic tak/werkorgan. - lelding/collega's

ward./werkkrlng warzulmfrequento
}

- n per groep 165-459

Eiguur 3.5 De tatalscore en de VAG korte versie met relatief gemiddelde 100 in voortschrijdende wijfjalrs leeftijdsgroepen (mannelljke en vrouwelijke werknemers samen*)

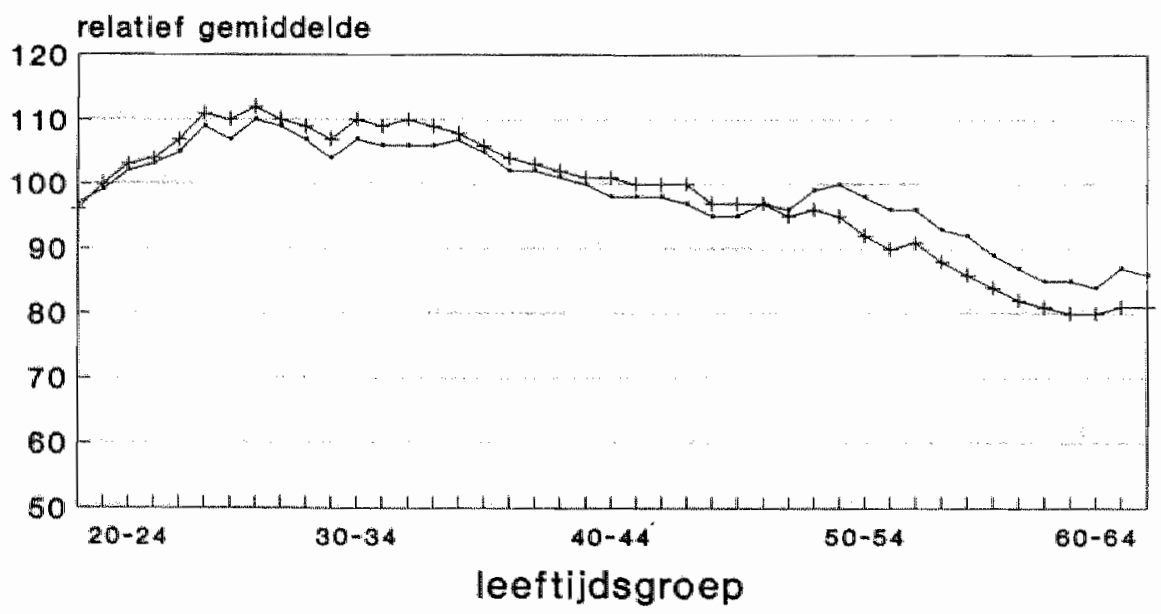

- totaalscore $\rightarrow$ VAG korte versie

- n per groep $16.5-459$ 
De totaalscore en de korte VAG nemen flauw af met de leeftijd en verder zijn er duidelijke leeftijdsverschillen in de richting van tabel 3.11. De verwachting in de geest van Rhodes (op. cit.) dat oudere werknemers een positiever beeld van hun werk hebben dan jongere wordt bevestigd door de bij toenemende leeftijd afnemende scores (minder problemen) op de index Werksituatie. Deze afname zou kunnen betekenen dat oudere werknemers zorgelozer worden over hun werk en werkomstandigheden. Het stemt ook overeen met de leeftijdstrend in het Leefsituatie-onderzoek van het CBS (Bloemhoff \& Smulders, ter perse). De betekenis van deze leeftijdsverschillen is niet bij voorbaat helder, omdat ze zowel een verbetering in de werksituatie zouden kunnen inhouden als een verandering in de maatstaven van de ouderwordende werknemer. Bloemhoff \& Smulders pleiten voor een interpretatie in de werksituatie: het werk van jongere werknemers kent ook in werkelijkheid relatief veel eentonigheid, hoog tempo, lichamelijke zwaarte, wuil, gevaar, stank en risico; verder hebben jongeren in doorsnee langere werkweken en meer plaegendienst. De daling met leeftijd van de index Werksituatie is daarom een valide weerspiegeling van de kwaliteit van werk en werkomstandigheden.

\section{Samenstelling van de indices, lange versie}

Er bleken hiervoor twee groepen variabelen onderscheiden te kunnen worden en om dat tot zijn recht te laten komen zijn er twee indices geconstrueerd door optelling van de betreffende somscores. De samenstelling van beide indices wordt aangegeven in tabel 3.12 .

Iabel 3.12 Samenstelling van de tmee indices, die twee groepen somscores* van de lange VAG weergeven

\begin{tabular}{|c|c|c|}
\hline index & somsicores & aantal vragen \\
\hline & Inspanning & \\
\hline \multirow[t]{4}{*}{ Conditiet } & Giezondhe id & 44 \\
\hline & Ziektegedrag & \\
\hline & Materiële Werkomstandigheden & \\
\hline & Taak en Werkorganisatie & 73 \\
\hline \multirow[t]{2}{*}{ Werksituatiel } & Leiding en Collega's & \\
\hline & Waardering Werkkring & \\
\hline
\end{tabular}

zie bijlage 3 
Enkele opmerkingen over de benaming van de indices. Bij de eerste groep somscores (Inspanning $\mathrm{t} / \mathrm{m}$ Ziektegedrag) is afgezien van termen als belasting en belastbaarheid omdat deze metingen suggereren, onafhankelijk van de mening van de werknemer. In plaats daarvan is Conditie gekozen, omdat dit een globaal begrip is, dat verder in het midden laat wat oorzaak en wat gevolg is. De tweede groep somscores (Materiele Werkomstandigheden $t / m$ Waardering Werkkring) verwijst niet naar de werknemer zelf, maar naar de werksituatie. De naam Werksituatie lag daarom voor de hand.

De indices van tabel 3.12 zijn ontleend aan de lange VAG. Verderop (paragraaf 3.7) worden twee parallelle maten behandeld die ontleend zijn aan de korte versie van de VAG. Om de herkomst aan te geven worden de indices benoemd als Conditie $_{\mathfrak{l}}$ en Werksituatie respectievelijk Conditie $_{\mathrm{k}}$ en Werksituatie $_{\mathrm{k}}$.

\section{Eigenschappen van de indices, lange versie}

Net als bij de somscores zullen de eigenschappen van de twee indices worden behandeld, allereerst de gemiddelden en standaardafwijkingen (vergelijk paragraaf 3.6.2). Zijn dit "normale" waarden in de vier bedrijven? Zo niet, dan wordt latere generalisatie van resultaten problematisch. Tabel 3.13 geeft de cijfers voor deze vergelijking.

Tabel 3.13 Percentages klachten en standaardafwijkingen van de indices Conditite en werksituatiel in de vier onderzochte bedrijven en een referentiegraep van zes andere bedrijiven

\begin{tabular}{lcccc}
\hline & \multicolumn{2}{c}{ percentage } & & \multicolumn{2}{c}{ standaardafwijking } \\
\cline { 2 - 5 } Index & vier bedrijven* & referentie** & vier bedrijuen* referentie** \\
\hline Conditiel & $19.6^{* * *}$ & $17.8 * * *$ & 16.5 & 15.8 \\
Werksituatiel & 22.1 & 22.1 & 14.9 & 14.1 \\
\hline
\end{tabular}

* $n=3486$

* $\mathrm{m}=3065$

**** significant, $p<0.05$

In de vier bedrijven is Conditie, iets hoger dan in de vergelijkingsgroep en de standaardafwijking is iets groter. De beide groepen bedrijven vallen wat betreft 
de index Werksituatie, zelfs samen. De vier bedrijven hebben op beide indices geen sterk afwijkende waarden hebben, zodat er wat dit betreft geen bezwaar tegen is, de uitkomsten te generaliseren.

De interne consistentie van de twee indices per bedrijf en in totaal wordt weergegeven door tabel 3.14.

Iabel 3.14 Interne consistenties van de findices conditiel en Werksituatiel uit de lange VAC per bedriff en in totaal (Crombach alpha)

\begin{tabular}{|c|c|c|c|c|c|}
\hline \multirow[b]{2}{*}{ somsicore } & \multicolumn{4}{|c|}{ bedpijt } & \multirow[b]{2}{*}{$\begin{array}{r}\text { totaal } \\
(n=3486)\end{array}$} \\
\hline & $\begin{array}{l}n \\
(n=585)\end{array}$ & $\begin{array}{l}(n=1451)\end{array}$ & $\begin{array}{l}c \\
(n=664)\end{array}$ & $\begin{array}{l}D \\
(786)\end{array}$ & \\
\hline Conditiel & $.87 k$ & .90 & .89 & .92 & .90 \\
\hline Werks i tuat jel & .88 & .91 & .91 & .93 & .91 \\
\hline
\end{tabular}

* te lezen als $0.87 \mathrm{enz}$.

De meeste alpha's bereiken de 0.90 en de overige komen daar maar weinig onder. De betrouwbaarheid van deze indices is dus (zie paragraaf 3.6 .3 ) voldoende.

We zullen verder kort nagaan welke waarden Conditie en $_{\text {Werksituatie }}$ aannemen in verschillende doorsneden van het materiaal, eerst naar leeftijd. Zie tabel 3.15 .

Iabel 3.15 Gemiddelden van de indices conditlel en Werksituatiel in verschillende dour sneden wan het materiaal

\begin{tabular}{|c|c|c|c|c|}
\hline Gezichtspunt & Groep & Condit tie! & Werksituatien & antal \\
\hline & $16-34 j$ & $16 . B^{4}$ & $25 \cdot 4 *$ & 1377 \\
\hline \multirow[t]{2}{*}{ leeftijd } & $35-49 \mathrm{j}$ & $19.1^{*}$ & $22.4 *$ & 1218 \\
\hline & $50+\quad j$ & $24.3^{*}$ & $16.6^{*}$ & 891 \\
\hline \multirow[t]{2}{*}{ bedrijfssector* } & produkt is & $20.5^{*}$ & 24.0 & 2467 \\
\hline & overig & $17.2^{4}$ & 17.4 & 1019 \\
\hline totaal & $=$ & 19.6 & 22.1 & 3486 \\
\hline
\end{tabular}

verschillen significant $p<0.05$

* zie paragraaf 2.2 .5 
De index Conditie ${ }_{\mathfrak{l}}$ neemt uiteraard toe met stijgende leeftijd en de index Werksituatie, neemt af, zie ook figuur 3.6 .

Elguur 3.6 De indices Conditie, en Werksituatie, met relatief geniddelde 100 in voortschrijdende vijfjaars leeftijdsgroepen (mannelijke en vrouwel fjke werknemers samen*y

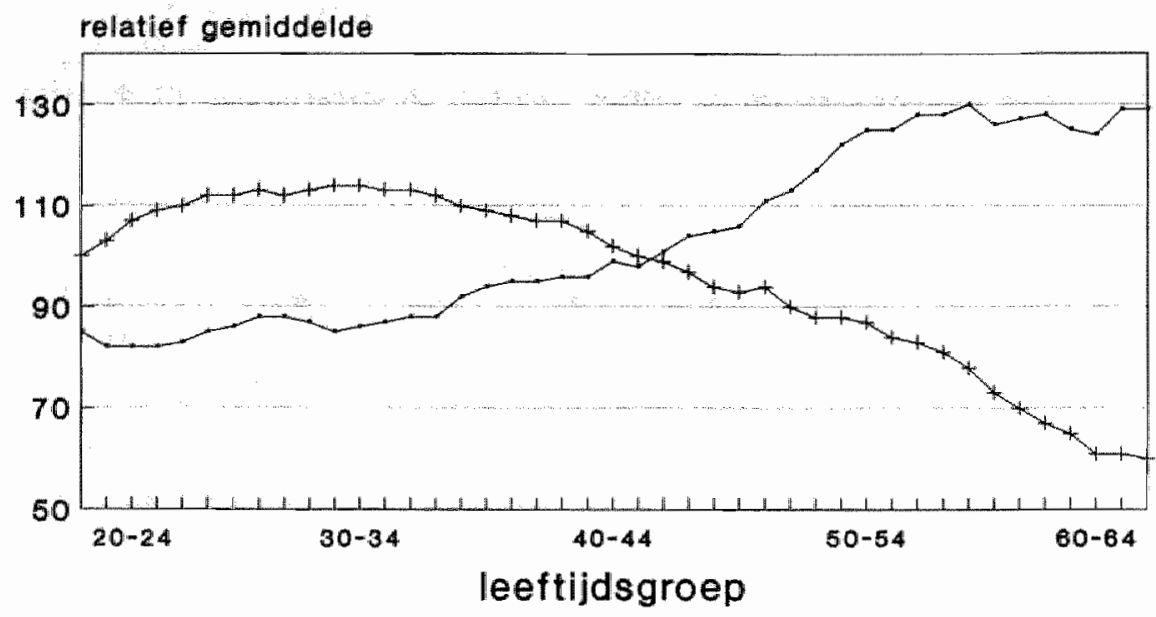

- conditie (1) $\rightarrow$ werksituatie (1)

- n per groep 165-459

Verder zijn er in de produktie iets hogere gemiddelden dan in de overige afdelingen. Dit zou kunnen betekenen dat het vertrek in produktieafdelingen beter te voorspellen is dan overige afdelingen.

3.7 Verklarende variabelen: meningen in somscores, VAG korte versie

3.7.1 Aard en inhoud van de VAG korte versie

De lange versie van de VAG met zijn 117 vragen (zie paragraaf 3.6 ) is in een bedrijfssituatie niet gemakkelijk en snel af te nemen. De gemiddelde invulduur van de lange VAG is ongeveer een uur (zie paragraaf 3.6.3). Afgezien nog van de verwachtingen, die het gebruik van een zo uitgebreid onderzoeksinstrument 
bij de werknemers kan wekken, is het tijdsbeslag voor de afname van de vragenlijst vaak een bezwaar voor de arbeidsorganisatie. In de praktijk is er daarom behoefte aan een korte versie, die vlug af te nemen is. In een vroeg stadium van de ontwikkeling van de VAG is er dan ook een korte versie ontwikkeld die bestaat uit eenenveertig vragen; veertig over aspecten van werk en gezondheid en één totalwaardering (Dijkstra e.a., 1981). De vragen van de korte VAG zijn te zien in bijlage 2 . De eerste veertig vragen ervan zijn de best discriminerende vragen (theoretisch het dichtst bij een verdeling van $50 \%$ ja- en $50 \%$ nee-antwoorden) binnen elk van de acht dimensies die binnen het toenmalige materiaal konden worden onderscheiden (één meer dan de zeven somscores die later zijn aangehouden, zie bijlage 3). Deze score op de korte VAG is het percentage problemen bij de eerste veertig vragen (zie paragraaf 3.6 .1 ).

De VAG korte versie heeft natuurlijk niet de pretentie, evenveel gedetailleerde informatie te geven als de lange versie. De korte versie geeft niet alle, maar wel de wezenlijke informatie. Het is de bedoeling, er een globale schatting mee te kunnen maken van de mening over arbeid en gezondheid van werknemers. Verderop (paragraaf 3.7.5) zal echter toch worden nagegaan of het mogelijk is, twee dimensies in de VAG korte versie te onderscheiden, namelijk Conditie ${ }_{k}$ en Werksituatie $\mathrm{k}_{\mathrm{k}^{*}}$ Voor die verwachting zijn twee gronden. Ten eerste kan op grond van de literatuur verwacht worden, dat deze twee dimensies een verschillende rol spelen bij vertrek door arbeidsongeschiktheid, vervroegd uittreden en ontslagname. Ten tweede bleek dat er bij de lange versie van de VAG duidelijk twee groepen somscores konden worden onderscheiden. In dit licht worden hieronder achtereenvolgens behandeld: de verdeling; de betrouwbaarheid en de validiteit van de scores op de korte VAG en de twee delen daarvan.

\subsubsection{Gemiddelde en spreiding van de VAG korte versie}

De score van de VAG, ook de korte versie, is het percentage gemelde problemen (zie paragraaf 3.6.1). Een belangrijke vraag met het oog op later generalisatiemogelijkheden is, hoe in het beschikbare materiaal het gemiddelde en de spreiding van de VAG korte versie liggen, vergeleken met onze referentiegroep van andere bedrijven (paragraaf 3.6 .2 ). Tabel 3.16 geeft de cijfers. 
Iabel 3.16 Percentages problemen en standaardafwijkingen wan de vale korte versie in de wier onderzochte bedrijuen en een referentiegroep van zes andere bedrijuen

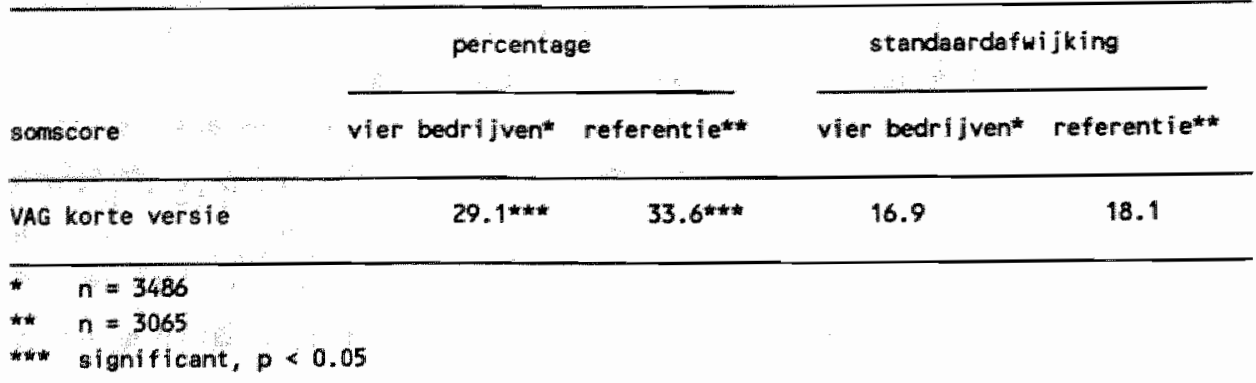

Er zijn wel zekere verschillen, want het klachtenpercentage in de vier bedrijven ligt 4.5 lager en de standaardafwijking ligt 1.2 lager dan in de vergellijkingsgroep. Dit is vergelijkbaar met de overige somscores, zie paragraaf 3.6.2. In de vier bedrijuen is de spreiding in de VAG kort dus kleiner dan in de vergelijkingsgroep en dat betekent dat de verbanden met vertrek uit het werk in onze vier bedrijven zeker niet sterker zullen zijn dan die in de referentiegroep. Eerder zal er onderschatting van de werkelijke verbanden te zien zijn in de resultaten van hoof dstuk 5 .

\subsubsection{Betrouwbaarheid van de VAG korte versie}

De bewerking en de maatstaven hier stemmen overeen met die van paragraaf 3.6.3, als maat voor de betrouwbaarheid is Cronbach's alpha genomen. Alpha geldt als een schatting van de ondergrens van de betrouwbaarheid, dus de werkelijke waarden van de betrouwbaarheid zullen hoger liggen dan de in tabel 3.17 vermelde.

IapeL 3.17 VAG karte versie: interne consistentie (Cronbach's alpha) bedrijf

somscore

$\begin{array}{llll}A & B & c & 0 \\ (n=585) & (n=1451) & (n=664) & (786)\end{array}$

VAG kante versie

$.81^{*}$

.85

.86

.89

.85

* te lezen als $0.81 \mathrm{enz}$. 
Alle waarden van Cronbach's alpha liggen tussen 0.80 en 0.90 wat een aanvaardbaar resultaat is. De test-hertestbetrouwbaarheid van de korte VAG werd al vermeld in paragraaf 3.6 .3 ; deze ligt tussen 0.85 en 0.91 . De conclusie hier kan zijn, dat de betrouwbaarheíd van de VAG korte versie voldoende is.

\subsubsection{Validiteit van de VAG korte versie}

Voor de verschillende aspecten die aan de validiteit kunnen worden onderscheiden zij verwezen naar paragraaf 3.6.4. De predictieve validiteit komt aan de orde in hoofdstuk 5, waar de voorspelling van de uitval uit het werk met behulp van de korte VAG behandeld wordt. Verder gelden voor de validiteit van de korte wersie van de VAG dezelfde argumenten als voor de lange versie (paragraaf 3.6.4). In het kort zijn deze de volgende: 1) vragen aan werknemers is de aangewezen methode, gezien het doel van het instrument: nl. het vaststellen van de mening over arbeid en gezondheïd van de werknemer; 2) het percentage gemelde problemen is een goede samenvatting van de informatie uit de vragen; 3 ) de vragen dekken een groot deel van het relevante domein van arbeid en gezondheid. De korte VAG voldoet daarmee aan de validiteitseisen.

\subsubsection{Twee groepen somscores, indices korte $\mathrm{VAG}$}

De korte versie van de VAG is een selectie van vragen uit de lange versie. De lange VAG bleek gesplitst te kunnen worden in twee delen: $\mathrm{nl}$. Conditie, en Werksituatie, (zie paragraaf 3.6.5). Het lag daarom voor de hand, na te gaan of het ook zin heeft, twee delen binnen de korte VAG te onderscheiden. Daarom zijn er, parallel aan de twee indices Conditie, en Werksituatie, van de lange VAG, twee indices uit de korte VAG samengesteld: Conditie $_{k}$ en Werksituatie ${ }_{k}$. Zie voor de samenstelling van de laatste bijlage 4. De vijftien vragen in Conditie $_{k}$ gaan over arbeidsinspanning, vermoeidheid en spanningsklachten, medicijngebruik "doktersbezoek, behandelingen voor ziekten en ziekteverzuim. Werksituatie $_{k}$ telt 25 vragen, onder meer over voldoende scholing en afwisseling in thet werk, het luchtklimaat, de organisatie van het werk, de werkrelaties, de ervaren waardering en de vooruitzichten in het werk. 
Eigenschappen van de indices, korte versie

Om een eerste beoordeling mogelijk te maken van de indices uit de korte VAG zijn in tabel 3.18 de klachtenpercentages en de standaardafwijkingen van Condi$t_{i} e_{k}$ en Werksituatie ${ }_{k}$ vermeld. Voor de aard van de bedrijven in de referentiegroep zie paragraaf 3.1 .

Iabel 3.10 Percentages klachten en standaardafuljkingen van conditie en Merks ituatie in de vier onderzoeksbedrijven en een referentiegroep van zes andere bedrijven

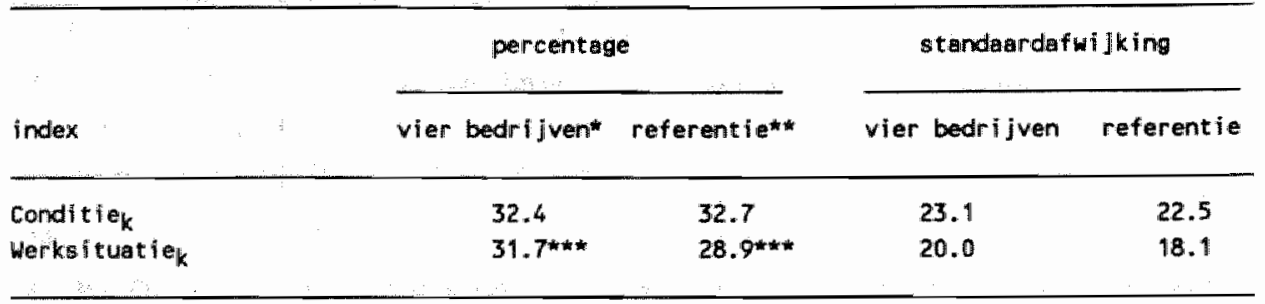

$n=3486$

*in $n=3065$

*** significant, $p<0.05$

Alleen Werksituatie ${ }_{k}$ vertoont een significant verschil tussen de groepsgemiddelden; dit verschil is echter relatief klein. Net als bij de somcores van de lange VAG (paragraaf 3.6.2) en de korte VAG als geheel (paragraaf 3.7.2) is duidelijk, dat de indices van tabel 3.18 wat betreft hun gemiddelde en spreiding bruikbaar zijn voor de voorspelling van vertrek.

Geldt dit laatste ook voor de betrouwbaarheid? De interne consistentie wordt weergegeven in tabel 3.19.

Tabel 3.19 Interne consistentie van Conditie $e_{k}$ Werksituatie $e_{k}$ per bedrijł en in total (Cronbach's alpha)

\begin{tabular}{|c|c|c|c|c|c|}
\hline \multirow[b]{2}{*}{ index } & \multicolumn{4}{|c|}{ bedrijf } & \multirow[b]{2}{*}{$\begin{array}{r}\text { totanl } \\
(n=3486)\end{array}$} \\
\hline & $\begin{array}{l}A \\
(n=585)\end{array}$ & $\begin{array}{l}B \\
(n=1451)\end{array}$ & $\begin{array}{l}c \\
(n=064)\end{array}$ & $\begin{array}{l}D \\
(786)\end{array}$ & \\
\hline Conditie & $.75^{\star}$ & .80 & .77 & .83 & .79 \\
\hline Werksituati $e_{k}$ & .78 & 83 & .83 & .86 & .83 \\
\hline
\end{tabular}

te lezen als 0.75 etc. 
De alpha van Conditie ${ }_{k}$ per bedrijf loopt van 0.77 tot 0.83 en die van Werksituatie $e_{k}$ van 0.78 tot 0.86 en de alpha over de vier bedrijven ligt bij beide indices daar tussenin. Op zich zijn deze waarden heel redelijk en vergeleken met de alpha van de somscores uit de lange VAG (tabel 3.7) zijn zij bepaald niet slechter. De conclusie is, dat de betrouwbarheid van de twee indices uit de korte VAG aan de eisen (paragraaf 3.6 .3 ) voldoet.

Tot slot kunnen we nagaan of de hoogte van de beide indices binnen werschillende groepen werknemers ligt zoals redelijkerwijs te verwachten is (vergelijk paragraaf 3.6.4). Het idee is, dat de gezondheidsproblemen (Conditie ${ }_{k}$ ) met de leeftijd toenemen en dat de werkomstandigheden (Werksituatie ${ }_{k}$ ) in de produktie meer klachten geven dan in de overige afdelingen. Tabel 3.20 geeft de cijfers.

Tabel 3.20 Gemiddelden van Conditiek en Werksituatiek in verschillende doorsheden van het material

\begin{tabular}{|c|c|c|c|c|}
\hline gezichtspunt & groep & Conditie & Herksit tuati $e_{k}$ & auntal \\
\hline & $16-341$ & $29.3^{*}$ & $35.9 *$ & 1377 \\
\hline \multirow[t]{2}{*}{ leeftijd } & $35-49$ & $32.8^{k}$ & $32.3^{*}$ & 1218 \\
\hline & $50+\quad j$. & $36.5^{*}$ & $24: 5 *$ & 891 \\
\hline \multirow[t]{2}{*}{ bedrif ifssectork* } & produktie & $33.0 *$ & $33.8^{\star}$ & 2467 \\
\hline & overig & $30.9 *$ & $26.6^{*}$ & 1019 \\
\hline total & $\ldots \ldots$ & 32.4 & 31.7 & 3486 \\
\hline
\end{tabular}

* verschillen significant, $p<0.05$

* zie paragraaf 3.1

Conditie $_{\mathrm{k}}$ neemt met toenemende leeftijd toe en Werksituatie $_{\mathrm{k}}$ is in do produktie hoger dan in de overige afdelingen, twee argumenten voor de validiteit van de beide indices.

We willen net als in paragraaf 3.6 .5 ook grafisch laten zien wat deze indices voor verband met leeftijd hebben (figuur 3.7). 
Elgour 3,7 De findices conditiek en werksituat fek net retatief gemiddelde 100 in voortschrijidende vifjaars leeftijdsgroepen (mannelfjke en vrouwetijke werknemers. samen*

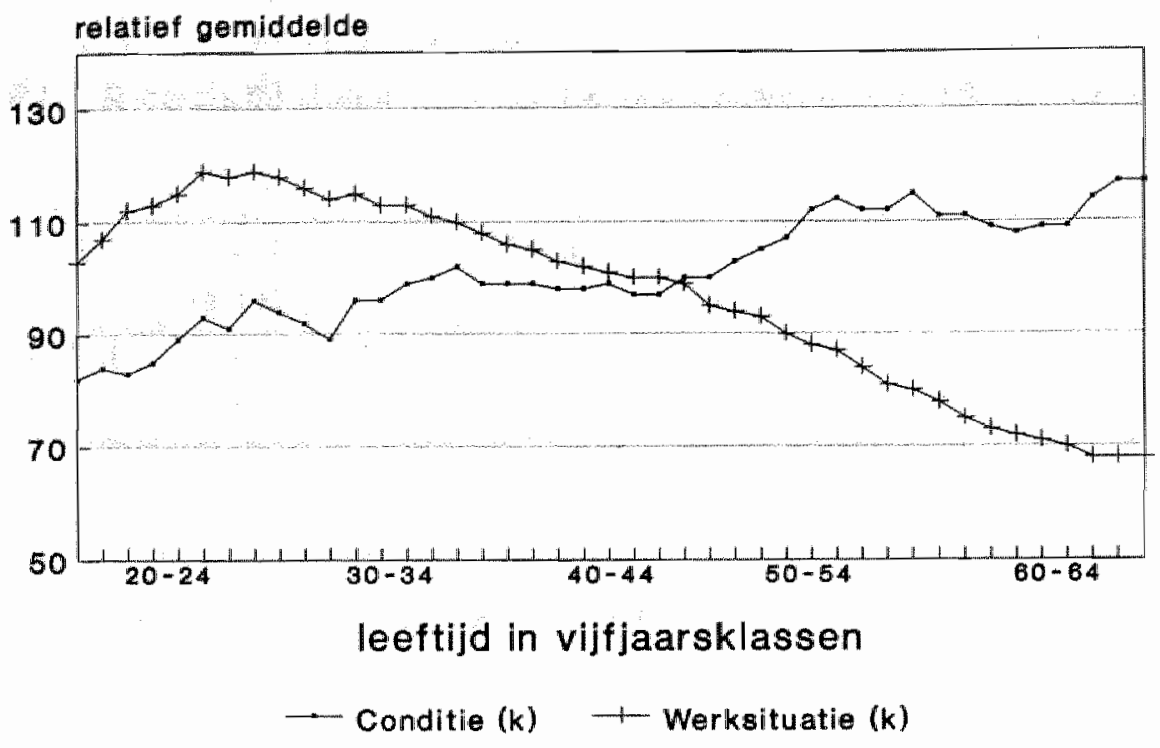

- n per groep 165-459

Het verloop van beide curven is vrijwel hetzelfde als dat in figuur 3.4 die over de indices in de lange versie gaat, zodat de leeftijdsgebondenheid van de indices uit korte en lange VAG hetzelfde ligt. Bij de voorspelling van vertrek uit het

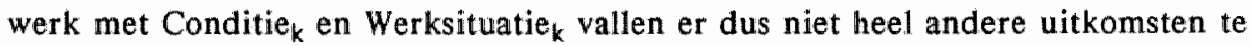
verwachten dan met Conditie, en Werksituatie,

\subsection{Verklarende variabelen: conclusle}

De volledige verzuimgegevens strekken van 1978 tot en met 1981 . Er zijn weliswaar verschillen tussen bedrijven en fluctuaties in de tijd, maar deze blijken binnen redelijk grenzen $( \pm 10 \%$ ) van de landelijke cijfers te blijven (zie paragraaf 3.5). Daarom hoeft niet van het gebruik van de verzuimgegevens af gezien te worden. 
Wat betreft de meningen van de werknemers blijken de zeven afzonderlijke somscores weinig af te wijken van wat in andere bedrijven gevonden werd en hun validiteit en betrouwbaarheid zijn bevredigend. Hetzelfde geldt voor de korte $V A G$ en voor de twee indices die uit de somscores van de lange VAG en uit de korte VAG zijn geconstrueerd.

Het is uit het voorgaande duidelijk dat de verklarende variabelen bruikbaar zijn voor het verklaren en misschien voorspellen van het latere vertrek van werknemers van de werkplek.

3.9 Te verklaren variabelen

\subsubsection{Aantallen vertrokken werknemers}

In tabel 3.21 worden de aantallen werknemers vermeld met alle voorkomende combinaties van vertrekwijzen, gesplitst naar leeftijd, geslacht en deelname aan het onderzoek. Er zijn drie vertrekwijzen, dus er zouden acht $\left(2^{3}\right)$ combinaties van vertrekwijzen kunnen zijn. Sommige van die combinaties zijn onmogelijk, nl. vervroegd uittreden en ontslag en de drie vertrekwijzen tegelijk. De aantallen werknemers in tabel 3.21 zijn beperkt tot degenen die vertrokken in of na het jaar van het bedrijfsonderzoek (ontslagname) resp. na dat jaar (arbeidsongeschiktheid en vervroegd uittreden). 


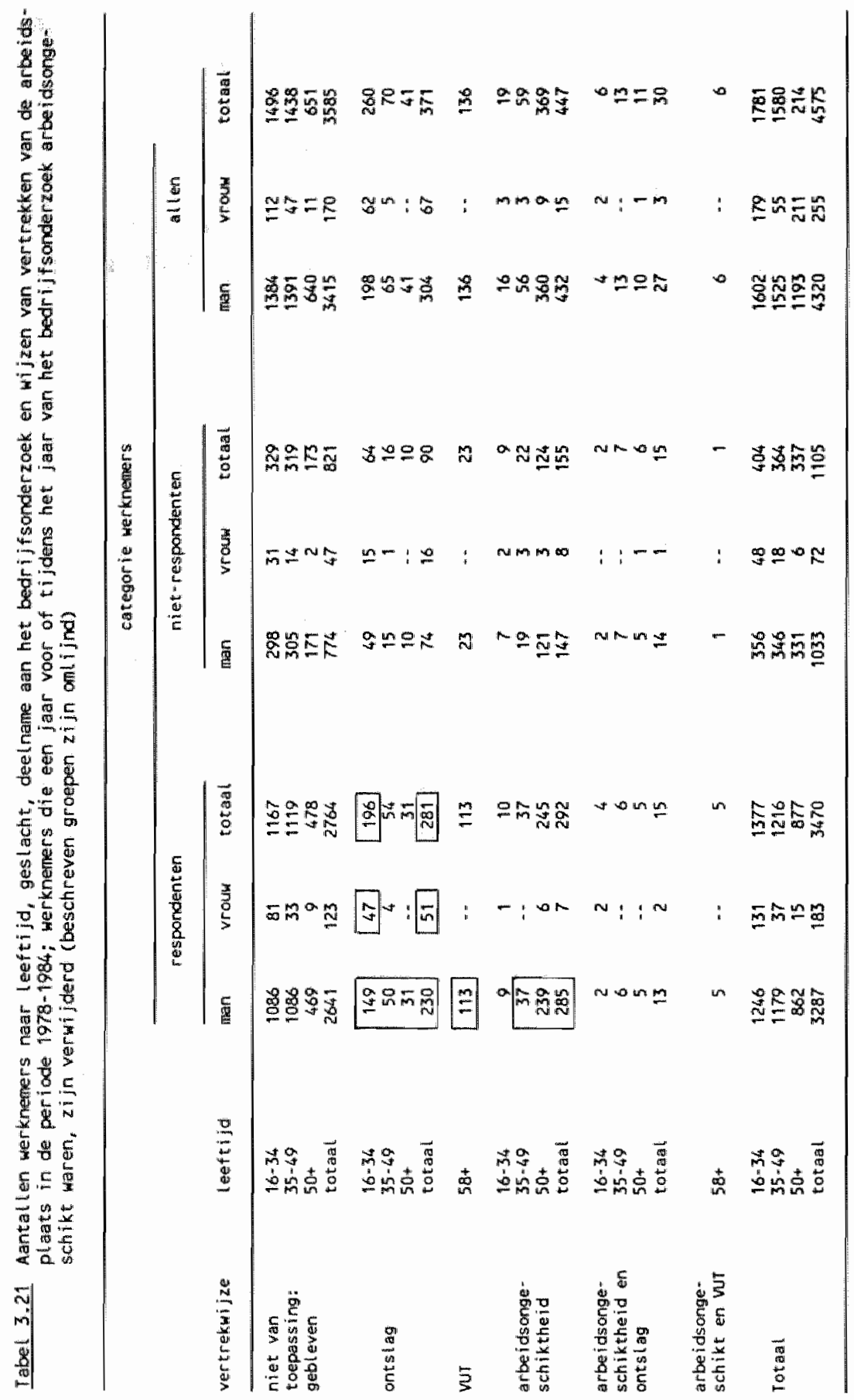


Een bijzonderheid bij de ontslagname in bedrijf $A$ is dat de waarnemingsperiode in en niet na het jaar van het bedrijfsonderzoek begint. De opgave van de ontslagjaren bleek achteraf deels onjuist en na correctie bleek een aantal ontslagen al in 1978 te hebben plaatsgevonden (zie tabel 3.1). Omdat deze ontslagnamen in elk geval na het bedrijfsonderzoek vielen is besloten, deze informatie niet verloren te laten gaan. Daarom zijn deze ontslagen niet verwijderd uit het materiaal.

Moet er aandacht besteed worden aan combinaties van vertrekwijzen? Er blijken uit tabel 3.21 dertig gevallen van arbeidsongeschiktheid, gevolgd door ontslagname, weinig ten opzichte van de 447 arbeidsongeschikten en de 372 ontsiagnamen. Verder zijn er zes personen met arbeidsongeschiktheid en VUT, ook relatief weinig. Er valt te concluderen dat er weinig gecombineerd vertrek voorkomt en dat dit beter uit de gegevens verwijderd kan worden, om het materiaal te zuiveren.

Om een indruk te geven van alle vertrek, volgen enige cijfers over de niet-beschouwde vertrekwijzen. Er gingen over de beschouwde periode 124 werknemers met ouderdomspensioen, van wie 95 zonder meer en 29 na een periode van arbeidsongeschiktheid; acht van hen zijn enige tijd herplaatst geweest in aangepast werk. Het aantal overledenen bedraagt vierenvijftig, van wie eén na ontslagname, éen na de VUT, negen na arbeidsongeschiktheid en twee na herplaatsing en eenenveertig zonder bijzonderheden. Er werden in total 107 werknemers herplaatst, van wie 90 alleen met arbeidsongeschiktheid en 17 met verschillende bijzonderheden. De aantallen werknemers met dergelijke bijzonderheden zijn klein ten opzichte van de aantallen genoemd in tabel 3.21 , zodat het feit dat ze buiten beschouwing gelaten worden, weinig invloed op de resultaten kan hebben.

De groepen werknemers van tabel 3.21 worden verschillend gepresenteerd bij de uitkomsten. Voor de voorspelbaarheid van de vertrekwijzen (hoofdstuk 4 en 5) worden de enquêtegegevens gebruikt en kunnen alleen de respondenten worden opgevoerd. Waar het om verzuim in de jaren voor het vertrek gaat, doet de deelname aran de enquête er niet toe en worden de cijfers van allen (respondenten en nonrespondenten) gebruikt. De twaalf omlijnde groepen zijn groot genoeg om hun gegevens aan bewerkingen te onderwerpen. 
Wat het vertrek van mannelijke en vrouwelijk werknemers betreft blijkt het volgende. Er zijn volgens tabel 3.21 duidelijk minder vrouwen dan mannen vertrokken er zijn geen vrouwelijke werknemers met de VUT gegaan en er zijn er maar weinig (achttien) arbeidsongeschikt geworden. Alleen de zevenenzestig ontslagnamen bil de vrouwelijke werknemers maken een bewerking mogelijk. Bij de mannelijke werknemers zijn de aantallen bij elk van de vertrekwijzen aanmerkelijk hoger, zodat bij hen bewerkingen gedaan kunnen worden over alle drie de wijzen van vertrekken.

Nog een opmerking over de VUT-groep. De VUT wijkt van de beide andere vertrekwijzen af, doordat er een vaste leeftijd voor gesteld is. In de vier bedrijven konden de werknemers op hun tweeënzestigste jaar de VUT kiezen. Om de vergelijkingsgroep zoveel mogelijk op de VUT-groep te laten lijken zijn de werknemers geselecteerd die in de waarmemingsperiode (zie tabel 3.1) eveneens in de gelegenheid waren om wel of niet met de VUT te gaan. Dat waren in bedrijf $A$ en $B$ de werknemers die 57 jaar, in bedrijf $C$ die 58 jaar en in bedrijf $D$ die 59 jaar waren tijdens het bedrijfsonderzoek. Achtenvijftig jaar is hier als modale leeftijd aangehouden van de groep potentiële VUT-ters.

Voor de waarde van de gegevens zou de vraag van belang zijn of er duidelijke patronen over de tijd in de vertrekwijzen aanwezig zijn. Tabel 3.22 geeft daarom per bedrijf en per jaar de percentages werknemers (mannelijke en vrouwelijke werknemers tezamen) die op verschillende wijze vertrokken.

Er zijn in tabel 3.22 verschillende tendenties te zien. De aantallen vertrokkenen (arbeidsongeschikten, VUT en ontslagname) zijn bij bedrijf A in 1979 hoger dan in elk ander bedrijf of jaar; dit kan samenhangen met de computerisering van een deel van thet productieproces. Verder dalen de aantallen arbeidsongeschikten in elk bedrijf en in het totaal. Bij de bedrijven is navraag gedaan, wat hier eventueel achter zit. Bij bedrijf $A$ werd vergrijzing als oorzaak genoemd, bij B het beleid van de bedrijfsarts (minder afkeuringen en meer herplaatsingen), bij $C$ is geen verklaring gevonden en bij D zou het zitten in de toename van de VUT. De verklaringen lopen dus uiteen, maar er zijn reële dalingen. 
Tebel 3.22 Percentages vertrokken werknemers" per bedrijf en per jaar, maximale $n=4661$

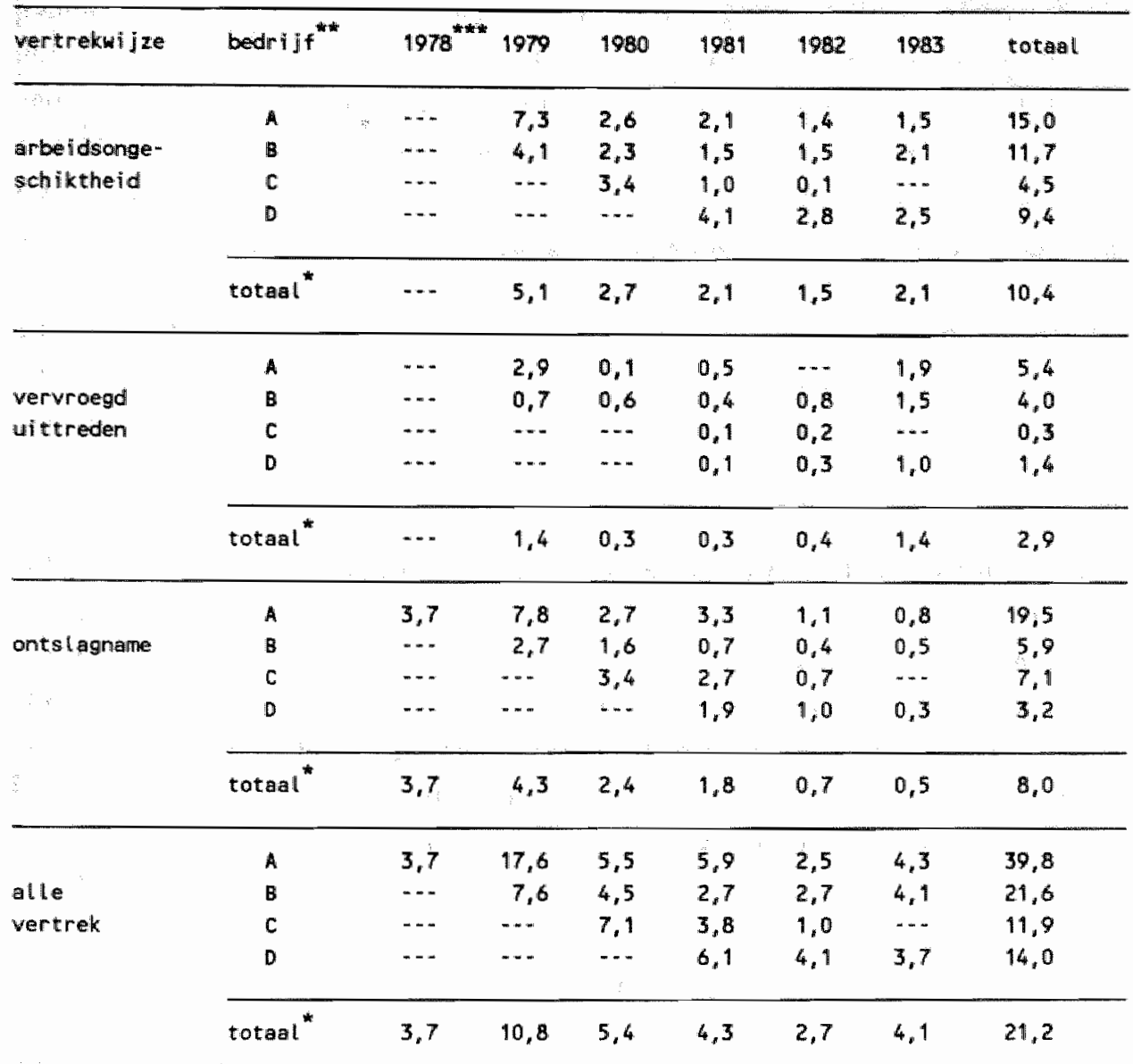

- Alle werknemers, arbefidsongesch iktheid gecombineerd met onts l agname.

* VAG-onderzoek A 1978, 8 1978, C 1979, D 1980.

* Percentage ten opzichte van aantal werknemers in gegeven jaar, daerdoor niet difnect per $r$ ij optelbat.

De aantallen werknemers in de VUT tonen, gerekend over het totaal, eerst een daling en dan een stijging. De aantallen per bedrijf zijn te klein om er veel aan te kunnen zien. De aantallen ontslagnamen per jaar suggereren een daling. Een langere waarnemingsperiode zou waarschijnlijk meer vertrekgevallen hebben opgeleverd, zeker in bedrijf $\mathrm{C}$ en $\mathrm{D}$ die maar kort werden gevolgd. 
Arbeidsongeschiktheid en VUT zouden volgens de literatuur (zie paragraaf 2.2.3) concurrerende regelingen kunnen zijn en dit zou consequenties kunnen hebben voor de resultaten van ons onderzoek. De concurrentiehypothese zou namelijk kunnen meebrengen dat bij gelijke uitstoot van vooral oudere werknemers, het ene bedrijf meer arbeidsongeschiktheid en het andere meer VUT zou vertonen. Bedrijfsverschillen in VUT en arbeidsongeschiktheid zouden zodoende de resultaten kunnen beïnvloeden; de variabele 'bedrijf' zou een confounder zou kunnen zijn. Doordat in tabel 3.22 sommige jaren ontbreken kunnen we dit niet rigoureus toetsen, maar we kunnen hiervan wel een indruk krijgen. Concurrentie tussen arbeidsongeschiktheid en VUT zou in termen van tabel 3.22 betekenen dat per bedrijf en jaar de som van de arbeidsongeschiktheids- en de VUT-percentages constant moet zijn en dat de arbeidsongeschiktheids- en de VUT-percentages negatief moeten samenhangen. Het een noch het ander is het geval, want de som van de beide percentages variëert sterk en de correlatie tussen de beide percentages is positief $(r=0.52)$. Er is daarom geen reden om in dit materiaal beducht te zijn voor concurrentie van arbeidsongeschiktheid en VUT (zie hiervoor ook ook hoofdstuk 4 en 5: de arbeidsongeschiktheids- en VUT-groep zijn verschillende groepen werknemers, de eerste heeft relatief veel, de tweede groep weinig problemen). De variabele "bedrijf' is in het datamateriaal geen confounder en de generaliseerbaarheid van de resultaten wordt daarom niet bedreigd.

\subsubsection{Gemiddelde leeftijd bij vertrek}

De gemiddelde leeftijden van de vertrokken werknemers worden vermeld in tabell 3.23 die de mannelijke en de vrouwelijke werknemers betreft. Er zal worden nagegaan of er leeftijdspatronen zijn waar rekening mee gehouden moet worden. 


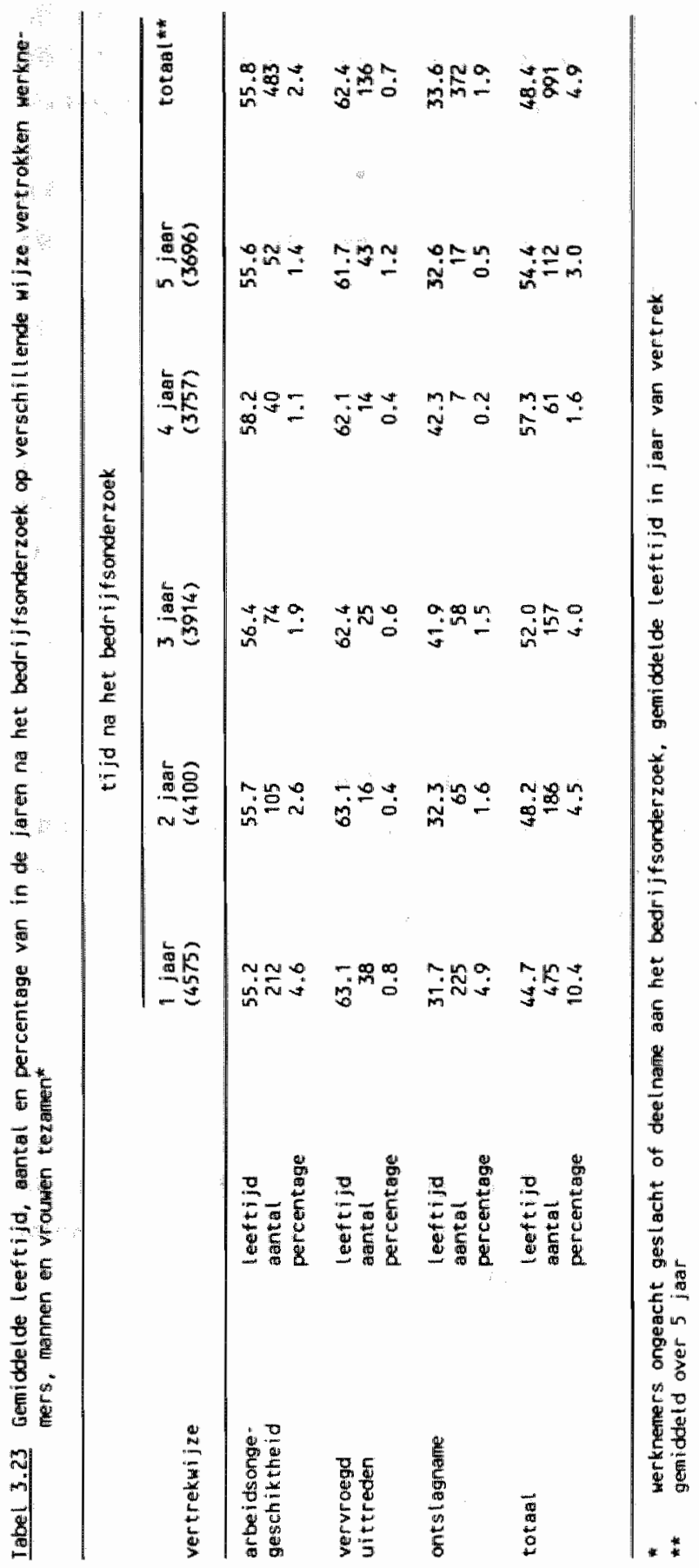


Bij de vrouwelijke werknemers zijn de gegevens niet over alle jaren aanwezig. Hun gemiddelde leeftijd bij arbeidsongeschiktworden ligt iets lager dan bij de mannen (48.1 resp. 56.1 jaar), hetzelfde geldt voor ontslag (26.5 resp. 35.2 jaar).

Alle ontslagen werknemers tezamen hadden een gemiddelde leeftijd van 33.6 jaar bij de ontslagname. In de leeftijd in de jaren na het bedrijfsonderzoek lijkt een sprong te zitten, maar die kan veroorzaakt zijn doordat bedrijf $C$ en $D$ er bijkwamen, bovendien zijn de aantallen laag, zodat niet te bepalen is of er wel van een reële sprong sprake is.

Het vervroegd uittreden gebeurde gemiddeld bij 62.4 jaar en er zijn vrijwel geen verschillen in de opeenvolgende jaren. Dat klopt met de VUT-leeftijd van 62 jaar die gold, vermeerderd met een half jaar voor de gemiddelde geboortemaand.

De arbeidsongeschiktheid trad op bij een gemiddelde leeftijd van 55.8 jaar met maar weinig variatie over de jaren en zeker geen systematische toe- of afname.

Wat betreft de leeftijd bij vertrek kan vastgesteld worden dat er geen systematische verschuivingen te zien zijn. Wat er aan verandering is, is gering (arbeidsongeschiktheid, VUT) of niet-systematisch (ontslag); daar hoeft dus in de bewerkingen of interpretaties geen rekening mee gehouden te worden.

\subsubsection{Vertrek in twee typen afdeling}

Eerder is een indeling gemaakt in produktie- en overige afdelingen (zie paragraaf 3.4) en hier is de vraag of deze verschillen in de aantallen vertrokken werknemers. Tabel 3.24 geeft de vertrekgevallen als percentage van het aantal werknemers bij de produktie- en de overige afdelingen.

Uit tabel 3.24 blijkt dat percentueel de bijdrage van de overige afdelingen groter is dan van de produktieafdelingen; dit geldt voor elk van de drie vertrekwijzen. Van Dijk e.a. $(1985,1987)$ vond dat bij een groot industriëel bedrijf de aantallen arbeidsongeschikten afnemen in de volgorde productie - onderhoud - kantoor. Hoewel de groepsindeling bij Van Dijk e.a. afwijkt van die in tabel 3.24 zou 
toch te verwachten zijn dat het percentage arbeidsongeschikten in de productieafdelingen hoger moet zijn dan in de overige afdelingen. Het is echter juist andersom, en dit kan drie betekenissen hebben: 1) het verschil bij Van Dijk e.a. is een eigenaardigheid van het door hen onderzochte bedrijf, 2) het verschil is een eigenaardigheid van de vier bedrijven van dit proefschrift of 3) de groepsindelingen lopen teveel uiteen om een zinvolle vergelijking te maken. Bij gebrek aan verdere gegevens is niet uit te maken wat de gevonden discrepantie betekent.

Tabel 3.24 Aartallen en percentages vertrokken werknemers in twee typen afdeling, ongeacht deelname aan het bedrijfsonderzoek

\begin{tabular}{|c|c|c|c|c|c|c|}
\hline \multirow{3}{*}{ wertrekwil ize } & \multicolumn{4}{|c|}{ type afdeling } & & \\
\hline & \multicolumn{2}{|c|}{$\begin{array}{l}\text { produktie } \\
(n=2685)\end{array}$} & \multicolumn{2}{|c|}{$\begin{array}{l}\text { overig } \\
(n=1472)\end{array}$} & \multicolumn{2}{|c|}{$\begin{array}{l}\text { totial } \\
(n=4157)^{*}\end{array}$} \\
\hline & aantal & $\%$ & aental & $\%$ & aental & $*$ \\
\hline \multicolumn{7}{|l|}{ arbeidsonge- } \\
\hline schiktheid & 251 & 9.3 & 174 & 11.8 & 425 & 10.2 \\
\hline vUT & 67 & 2.5 & 62 & 4.2 & $\$ 29$ & 3.1 \\
\hline \multicolumn{7}{|l|}{ antslag - } \\
\hline name & 189 & 7.0 & 134 & 9.1 & 323 & 7.8 \\
\hline \multicolumn{7}{|l|}{ alle } \\
\hline vertrek & 507 & 18.8 & 370 & 25.1 & $B 77$ & 21.1 \\
\hline
\end{tabular}

3.9.4 Vertrek bij uitvoerend en leidinggevend personeel

De laatste vraag die hier aan de orde komt is die naar verschillen tussen uitvoerend en leidinggevend personeel. Als definitie is aangehouden, dat iemand leidinggevend is zodra er een leidingsaspect in zijn functie zit. Een meewerkend voorman wordt bijvoorbeeld niet als uitvoerende, maar als leidinggevende geteld. De resultaten worden gegeven in tabel 3.25. 


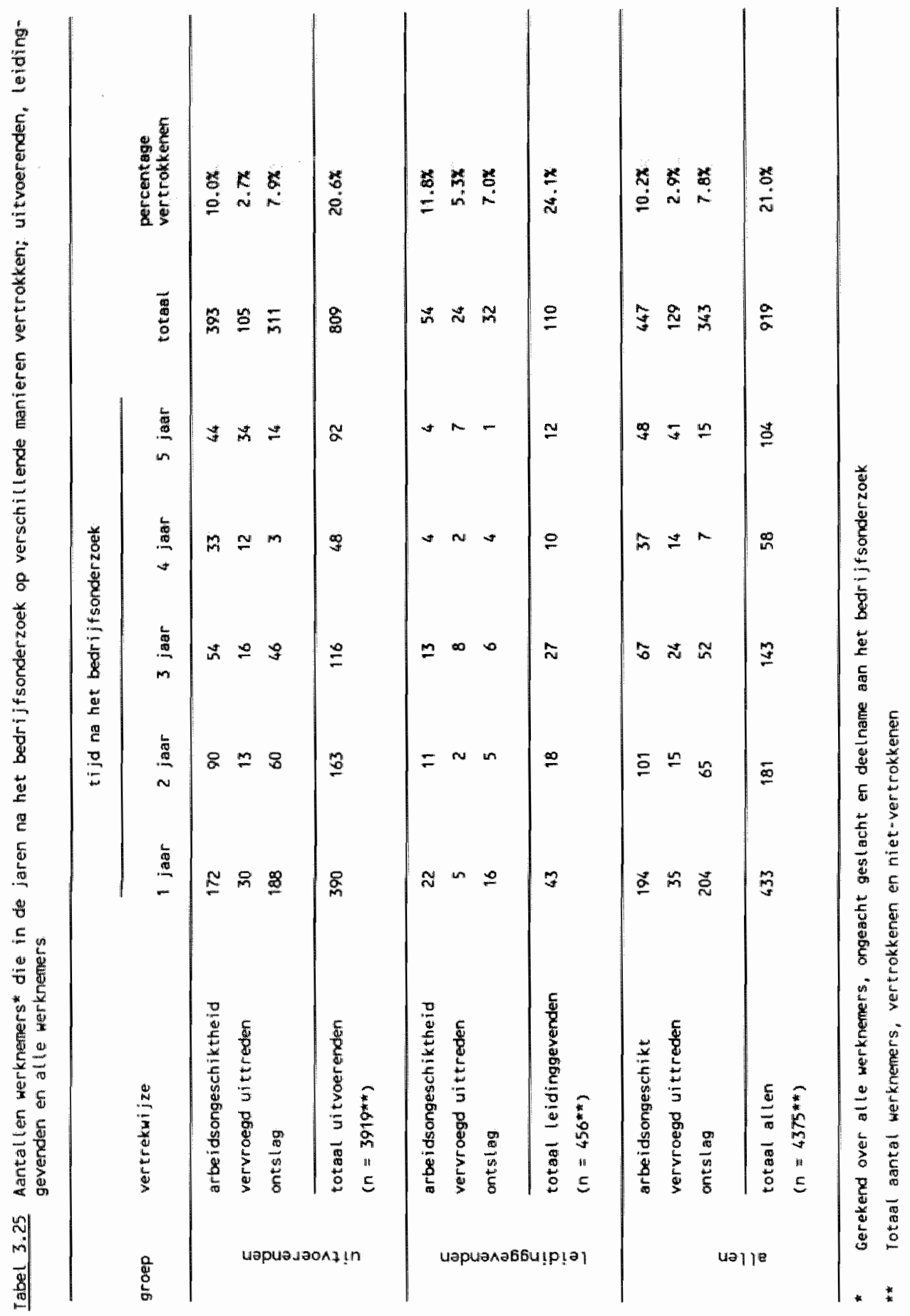


Uit tabel 3.25 blijkt dat er, over alle jaren gerekend, iets meer leidinggevenden dan uitvoerenden vertrokken zijn. Dat geldt voor arbeidsongeschiktheid en wervroegd uittreden, maar niet voor ontslagname, dat bij de lieidinggevenden wat lager ligt dan bij de uitvorenden. Hoewel de absolute aantallen bij de leidinggevenden laag zijn geven ze, net als bij de uitvoerenden, de tendentie te zien dat de uitval kort na het bedrijfsonderzoek hoger is dan enkele jaren daarna. Alleen over arbeidsongeschiktheid is in dezen vergelijkingsmateriaal beschikbaar.

Van Dijk e.a. (1987) geeft geen cijfers over leidinggevenden, maar wel over de salarisschalen. We mogen met Van Dijk e.a. aannemen dat salarishoogte en leidinggeven sterk samenhangen, want tabel 3.2 vermeldt een correlatie tussen beide gegevens van 0.55. Van Dijk e.a. vindt dat in de lagere sallarisgroepen (overwegend uitvoerenden) meer WAO optreedt dan in de hogere groepen (meer leidinggevenden); vooral bij het kantoorpersoneel is het verschil groot. Tabel 3.25 strookt niet met dit gegeven, want (zie eerder) er vertrokken naar verhouding meer leidinggevenden dan uitvoerenden. Net als in paragraaf 3.9.3 is de conclusie echter dat we niet kunnen uitmaken wat de hier gevonden afwijking voor de resultaten van ons onderzoek betekent.

Draaisma e.a. (1985) schat dat bij uitvoerenden in het algemeen ongeveer $2 \%$ en bij leidinggevenden $1 \%$ per jaar door arbeidsongeschiktheid vertrekt. Voor de uitvoerenden gaat dit bij benadering op, de arbeidsongeschiktheidscijfers van de leidinggevenden komen hier duidelijk boven. Dit wordt voornamelijk veroorzaakt door hoge cijfers in de eerste drie jaren na het bedrijfsonderzoek. De dalende trends in alle vertrekcijfers (ook die van arbeidsongeschiktheid) komen overigens voor een deel tot stand doordat van een statische populatie is uitgegaan. Degenen die ten tijde van het bedrijfonderzoek problemen hadden (arbeidsongeschiktheid) of over vertrek dachten (VUT en ontslagname) zijn binnen enkele jaren vertrokken; de toevloed van nieuwe werknemers na het bedrijfsonderzoek is buiten beschouwing gebleven. 
Het aantal vrouwelijke werknemers dat vertrok is laag, alleen bij ontslagname zijn de aantallen voldoende voor een nadere beschouwing. Bij het mannelijk personeel kunnen alle drie de vertrekwijzen (arbeidsongeschiktheid, VUT en ontslagname) worden gevolgd en daarbij is het zelfs mogelijk naar leeftijd te differentiëren. Bij de verdere bewerkingen zullen gezien de aantallen werknemers de volgende groepen beschouwd worden:

- ontslagname: mannen $16-34$ jaar, $35-49$ jaar, $50+$ jaar en totaal, vrouwen 16 - 34 jaar en totaal, mannen en vrouwen 16 - 34 jaar en totaal;

- verwroegd uittreden: mannen $58+$ jaar;

- arbeidsongeschiktheid: mannen 35 - 49 jaar, 50+ jaar en totaal.

Combinaties van vertrekwijzen worden daarbij buiten beschouwing gelaten. Wel wordt aandacht gegeven aan twee kenmerken die van belang bleken te zijn; leidinggevende tegenover niet-leidinggevende functies en produktie- tegenover overige afdelingen. Deze kenmerken maken een zekere specificatie van de vertrekwijzen, naast leeftijd en geslacht, mogelijk.

\subsection{Analysetechnieken}

De structuur van de gegevens is bij elke vertrekwijze gelijk. Of het nu gaat om gegevens uit de lange VAG (hoofdstuk 4) of de korte VAG (hoofdstuk 5), om arbeidsongeschiktheid, VUT of ontslagname, telkens is er een aantal verklarende variabelen die misschien voorspellers zullen blijken te zijn van een vertrekwijze binnen een bepaalde groep werknemers. De opgave is, bij elke vertrekwijze in een aantal stappen te bepalen of een verklarende variabele voldoende voorspellend vermogen heeft. Bij elk van de drie vertrekwijzen zijn de statistische en epidemiologische methoden daarom dezelf de.

Wil er van voorspelling van vertrek sprake kunnen zijn, dan moet er verschil zijn in de verklarende variabelen tussen de wel- en niet vertrokkenen. De vraag is daarbij nog niet of de verklarende variabelen in twee niveaus moeten worden ingedeeld voor voorspellingsdoeleinden. Het gaat er in eerste aanleg alleen om, te 
toetsen of er verschil is tussen wel- en niet vertrokkenen in de gemiddelden van de verklarende variabelen.

In de eerste bewerking wordt (d.m.v. een F-toets) bepaald of de verdelingen in de verklarende variabelen van de wel- en de niet-vertrokkenen verschillen. Verschillen de spreidingen (ma.w. is de F-toets significant), dan wordt gebruik gemakt van afzonderlijke varianties; zijn deze verschillen gering, dan worden de varianties gepoold. Met de al of niet gepoolde variantie wordt daarna een $t$-toets uitgevoerd om vast te stellen, of de gemiddelden van wel- en niet-vertrokkenen aanmerkelijk van elkaar verschilden. Dit leidt tot een selectie van variabelen die bij een bepaalde wijze van vertrekken voldoende veelbelovend zijn om nader aan de tand te gevoeld te worden.

Het proces dat achter het vertrek verondersteld wordt is (zie paragraaf 1.3 en 2.5) er in abstracte termen eén van toenemende klachten en misschien daarmee gepaard, toenemend verzuim. Bij de voorselectie van variabelen uit de eerste stap is het daarom logisch, na te gaan of deze ook inderdaad toenemen in de tijd vanaf het bedrijfsonderzoek tot aan het uittreden. Gebruik wordt gemaakt van inspectie van de gegevens, zonder formele toets.

De verzuimgegevens zijn over reeksen jaren verzameld (zie paragraaf 3.5 ), deze kunnen dus voor ons doel uitgezet worden in de tijd, dus in jaren ten opzichte van het vertrek uit het werk. De enquête- of VAG-gegevens zijn slechts eenmaal verzameld, ten tijde van het bedrijfsonderzoek (zie paragraaf 3.1). Deze gegevens kunnen wel geordend worden naar aantal jaren ten opzichte van het latere vertrek, maar (omdat wie vertrekt, dat maar eenmaal doet) daarbij bevat elke jaarklasse andere werknemers dan elke andere, zonder enige overlap. Dit maakt het, zoals blijken zal, lastig om conclusies te trekken. Niettemin zal dit worden geprobeerd.

$\mathrm{Na}$ dit voorwerk wordt er overgegaan tot het peilen van het voorspellend vermogen per variabele. De vraag is daarbij niet of er verschillen zijn tussen wel- en niet-vertrokkenen, want dat is al vastgesteld in stap 1 . Het gat daarbij evenmin om het verklaren van vertrekvariabelen, maar om het aangeven van de kans dat een werknemer met een bepaalde VAG-score of een bepaald verzuim zal ver- 
trekken door arbeidsongeschiktheid, VUT of ontslagname. Die kans zou kunnen worden uitgedrukt in de cumulatieve incidentie, d.w.z. de proportie vertrekgevallen bij een gegeven groep werknemers in een bepalde periode. De waarnemingsperiode per bedrijf verschilt echter van drie tot vijf jaar (zie tabel 3.1) en deze verschillen moeten natuurlijk verrekend worden in de vertrekkans. Om die reden wordt gebruik gemaakt van de incidentiedichtheid (Sturmans 1986); dit is het aantal vertrekgevallen per mensjaar (het aantal vertrekgevallen gedeeld door het product van het aantal werknemers en het aantal jaren).

Bij de individuele voorspelling van vertrek uit het werk wordt een verklarende variabele rond een bepaalde grens verdeeld in hoge en lage scores. De vraag is daarbij hoeveel meer kans op vertrek een hoog scorende werknemer heeft, vergeleken met een laag scorende. Dit wordt uitgedrukt in de incidentiedichtheidsratio (IDR). De IDR geeft de verhouding weer van de incidentiedichtheid (de kans op vertrek per tijdseenheid) in de hoogscorende groep ten opzichte van die in de laagscorende groep (Kleinbaum e.a., 1982; Sturmans, 1984). Er wordt uitgegaan van een $2 \times 2$ tabel zoals in figuur 3.8 aangegeven.

Eiguar 3.8 Grootheden in de incidentiedich theids ratio (IDR)

\begin{tabular}{lll} 
& \multicolumn{2}{c}{ score } \\
\cline { 2 - 2 } & aantal vertrokkenen & hoog \\
aantal mensjaren & $a$ & $b$ \\
& $L_{0}$ & $L_{1}$ \\
\hline
\end{tabular}

De incidentiedichtheidsratio is nu:

$$
I D R=\frac{b / L_{1}}{a_{/} L_{0}}=\frac{b L_{0}}{a L_{1}} .
$$

Als een IDR een waarde van een heeft, is er geen enkel kansverschil tussen werknemers met lage en met hoge scores. Hebben de hoogscoorders meer kans op vertrek, dan is de IDR groter dan 1 en omgekeerd. Er moet dus een bepaalde afwijking van één zijn, wil een IDR wijzen op een voorspelling. 
Het is technisch geen probleem, de statistische significantie van de IDR's uit te rekenen. Het bleek echter dat ook zulke kleine afwijkingen van de neutrale waarde (1.00) significant kunnen zijn, dat ze geen praktische waarde hebben; om die reden is hier van de toetsingsresultaten afgezien. In plaats daarvan worden twee epidemiologische aspecten van de predictieve validiteit van de IDR beschouwd, nl. de sensitiviteit en de specificiteit.

De grenzen tussen lage en hoge scores zijn waar mogelijk telkens $10 \%$ hoger gesteld, vanaf de laagste $10 \%$ tegenover de hoogste $90 \%$ van de scores (aangegeven als $10 / 90)$ tot en met de laagste $90 \%$ tegenover de hoogste $10 \%(90 / 10)$. De precieze grenswaarden zijn vermeld in bijlage 5 .

Bij een in hoog en laag verdeelde variabele is hier de sensitiviteit de mate waarin toekomstig vertrek wordt voorspeld door een hoge score; de specificiteit is de mate waarin toekomstig aanblijven voorspeld wordt door een lage score. Slechts bij een perfect verband tussen voorspeller en vertrek hebben de sensitiviteit en de specificiteit tegelijk de waarde éen (alle hoogscorende werknemers, en alleen die, vertrekken; alle laagscorende werknemers, en alleen die, blijven bij hun werkgever). Het is duidelijk dat een dergelijk ideaal niet bereikt, maar slechts benaderd kan worden. De sensitiviteit en de specificiteit moeten tegelijk zo hoog mogelijk zijn, wil de voorspelling slagen.

Tot nu toe is er steeds sprake van voorspelling van vertrek door één variabele tegelijk. Het doel is uiteraard, voorspellingen te baseren op alle relevante informatie voor een bepaalde vertrekwijze. Daartoe zijn er twee maatregelen genomen:

1) bundeling van afzonderlijke somscores tot vier brede indices, nl, uit de lan-

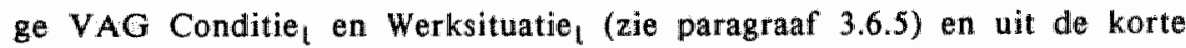
VAG Conditie $_{k}$ en Werksituatie $_{k}$ (paragraaf 3.7.5);

2) gebruik van tegelijk zo een index en een verzuimgegeven in de voorspelling (zie paragraaf $4.1 .4,4.2 .4,4.3 .4,5.1 .3,5.2 .3$ en 5.3 .3 ).

Bij al deze bewerkingen wordt gebruik gemaakt van logistische regressie, omdat er sprake is van een dichotome afhankelijke variabele (vertrek uit het werk) en gedichotomiseerde voorspellende variabelen (een VAG-index en een verzuimmaat boven of beneden een aangenomen grenswaarde). Met logistische regressie 
worden schattingen gemaakt van de parameters in een multiplicatief model, dat in dit geval de kans op vertrek (p) moet schatten (Breslow \& Day, 1980). Bijvoorbeeld:

$$
\log p /(1-p)=\log \text { it } p=\alpha+B_{1} x_{1}+B_{2} x_{2}+B_{3} x_{3}
$$

als er verondersteld wordt dat de vertrekkans afhangt van drie voorspellers, namelijk $x_{1}, x_{2}$ en $x_{3}$. Alpha is het intercept, een constante waarde zonder verdere bijzondere betekenis, de beta's zijn de gewichten die aan de voorspellers $x_{i}$ tot en met $x_{3}$ worden toegekend. Die gewichten geven aan, hoeveel de variabelen elk bijdragen aan de kans op vertrek, in termen van de 'odds ratio' of kansverhouding.

Ook bij deze voorspelling met meerdere variabelen wordt de validiteit vastgesteld met behulp van de sensitiviteit en de specificiteit (zie eerder).

\subsubsection{Samenvatting van het analyseplan}

In het kort worden achtereenvolgens bij elke vertrekwijze de volgende bewerkingen uitgevoerd. In termen van vraagstelling, bijbehorende techniek en resultaat kunnen we paragraaf 3.11 als volgt samenvatten:

1. Is er bij de verklarende variabelen wel verschil tussen de later wel en nietvertrokken werknemers? Techniek: F-toets voor all dan niet direct poolen en $t$-toets voor vaststellen al of geen verschil. Resultaat: selectie van veelbelovende verklarende variabelen

2. Nemen deze veelbelovende verklarende variabelen, zoals verwacht (par. 1.3), toe in de tijd tot aan het vertrek? Techniek: inspectie van de data. Resultaat: bijkomende informatie voor stap 1 .

3. Wat is het voorspellend vermogen van de afzonderlijke verklarende variabelen? Techniek: incidentiedichtheidsratio's (IDR's). Resultaat: nadere selectie van voorspellers.

4. Wat is bij de variabelen met een goed voorspellend vermogen de validiteit? Techniek: sensitiviteit en specificiteit. Resultaat: indruk van de bruikbaarheid van voorspellers. 
5. Wat is het voorspellend vermogen van tegelijk werknemersmeningen (VAG) en verzuimgegevens? Techniek: logistische regressie. Resultaat: schatting van de relatieve bijdrage aan de voorspelling van elk van de verklarende variabelen; schatting van de meerwaarde ten opzichte van voorspelling met één variabele.

6. Wat is in dit geval de validiteit? Techniek; weer sensitiviteit en specificiteit. Resultaat: bruikbaarheidsschatting van voorspelling met meer variabelen.

Op de hier geschetste manier mogen we hopen dat alle kanten van het voorspellend vermogen van de verklarende variabelen belicht worden. Daarmee wordt tegelijk een indruk gegeven van de voorspellende waarde van de verzuïmgegevens en de predictieve validiteit (zie paragraaf 3.6 .4 en 3.7 .4 ) van de gebruikte vragenlijst, de VAG. 
Arbeidsongeschiktheid, vervroegd uittreden (VUT) en ontslagname worden in respectievelijk paragraaf $4.1,4.2$ en 4.3 behandeld. Aan het eind van elke paragraaf worden de betreffende literatuur, de voorspelbaarheid wan het vertrek en de validiteit van de toegepaste vragenlijst besproken aan de hand van de uitkomsten. Tot slot wan dit hoofdstuk worden de resultaten in een algemene discussie aan de orde gesteld.

\subsection{Voorspelling van arbeidsongeschiktheid}

In deze paragraaf worden alleen resultaten met betrekking tot de mannelijke werknemers behandeld, omdat de aantallen vrouwelijke werknemers die arbeidsongeschikt werden binnen de waarnemingsperiode, te klein zijn om gefundeerde conclusies te kunnen trekken (zie paragraaf 3.9.1). Er wordt een indeling naar leeftijd aangehouden met als groepen $35-49$ jaar, 50 jaar of ouder en de totaalgroep. omdat hierbij nog voldoende aantallen vertrokken werknemers aangetroffen zijn.

Het Ziektewetjaar gaat direct aan de arbeidsongeschiktheid vooraf. Het komt laat in het proces van arbeidsongeschikt-worden en het vormt er een eenheid mee. Het hoge verzuim in het Zilektewetjaar kan daarom het niet als een zelfstandige voorspeller van arbeidsongeschiktheid worden beschouwd. Zou het verzuim in het Ziektewetjaar wèl als voorspeller gebruikt worden, dan zou het een kunstmatig hoog verband opleveren. In de hier te behandelen resultaten worden, om deze inflatie te vermijden, bij de voorspelling van arbeidsongeschiktheid het jaar van de afkeuring en het kalenderjaar daarvoor buiten beschouwing gelaten. (In paragraaf 4.1 .2 wordt slechts het verzuim in het jaar van de afkeuring buiten beschouwing gelaten, om de tendenties in de tijd beter te laten zien.) Door deze veiligheidsmaatregelen wordt inflatie van de verbanden vermeden. 
Om arbeidsongeschiktheid te kunnen voorspellen moeten er verschillen in de verklarende variabelen tussen wel- en niet-arbeidsongeschikten zijn. Teneinde na te gaan of aan deze eerste eis voldaan is, worden in tabel 4.1 de gemiddelden van alle verklarende variabelen voor de niet- respectievelijk wel met arbeidsongeschiktheid vertrokken werknemers in de onderscheiden groepen werknemers aangegeven.

Van de somscores Inspanning $\mathrm{t} / \mathrm{m}$ Waardering voor de Werkkring leveren alleen de eerste drie nl. Inspanning, Gezondheid en Ziektegedrag, over de hele linie aanmerkelijke verschillen tussen de beide groepen werknemers op. Hierbij hebben steeds de arbeidsongeschikten hogere scores (meer klachten) dan de nietarbeidsongeschikten.

De overige somscores in deze groep (Materiële Werkomstandigheden $\mathrm{t} / \mathrm{m}$ Waardering Werkkring) geven slechts in beperkte mate verschillen te zien en waar dat zo is, in omgekeerde richting. Binnen de groepen niet-leidinggevenden, produktie en alle werknemers is hier te zien, dat de vertrokkenen soms lagere scores hebben (minder klachten) dan de niet-vertrokkenen. De totaalscore van de arbeidsongeschikten is echter steeds hoger dan van de niet-arbeidsongeschikten.

De twee indices die groepen somscores samenvatten (zie par. 3.6.5) geven een verschillend beeld. De index Conditie, is bij alle groepen werknemers bij de arbeidsongeschikten significant hoger (meer klachten) dan bij de niet-arbeidsongeschikten. De index Werksituatie, kent wel een paar verschillen die andersom liggen (arbeidsongeschikten lager (minder klachten) dan niet-arbeidsongeschikten), maar dit gaat slechts voor enkele groepen werknemers op. Van de beide verzuimmaten is het verzuimpercentage binnen alle groepen werknemers hoog bij de arbeidsongeschikten en laag bij de niet-arbeidsongeschikten. De verzuimfrequentie laat maar in enkele groepen een flink verschil zien (nl. bij $50+$ jaar en bij de leidinggevenden). Hierbij is de frequentie bij de arbeidsongeschikten hoger dan bij de niet-arbeidsongeschikten. 


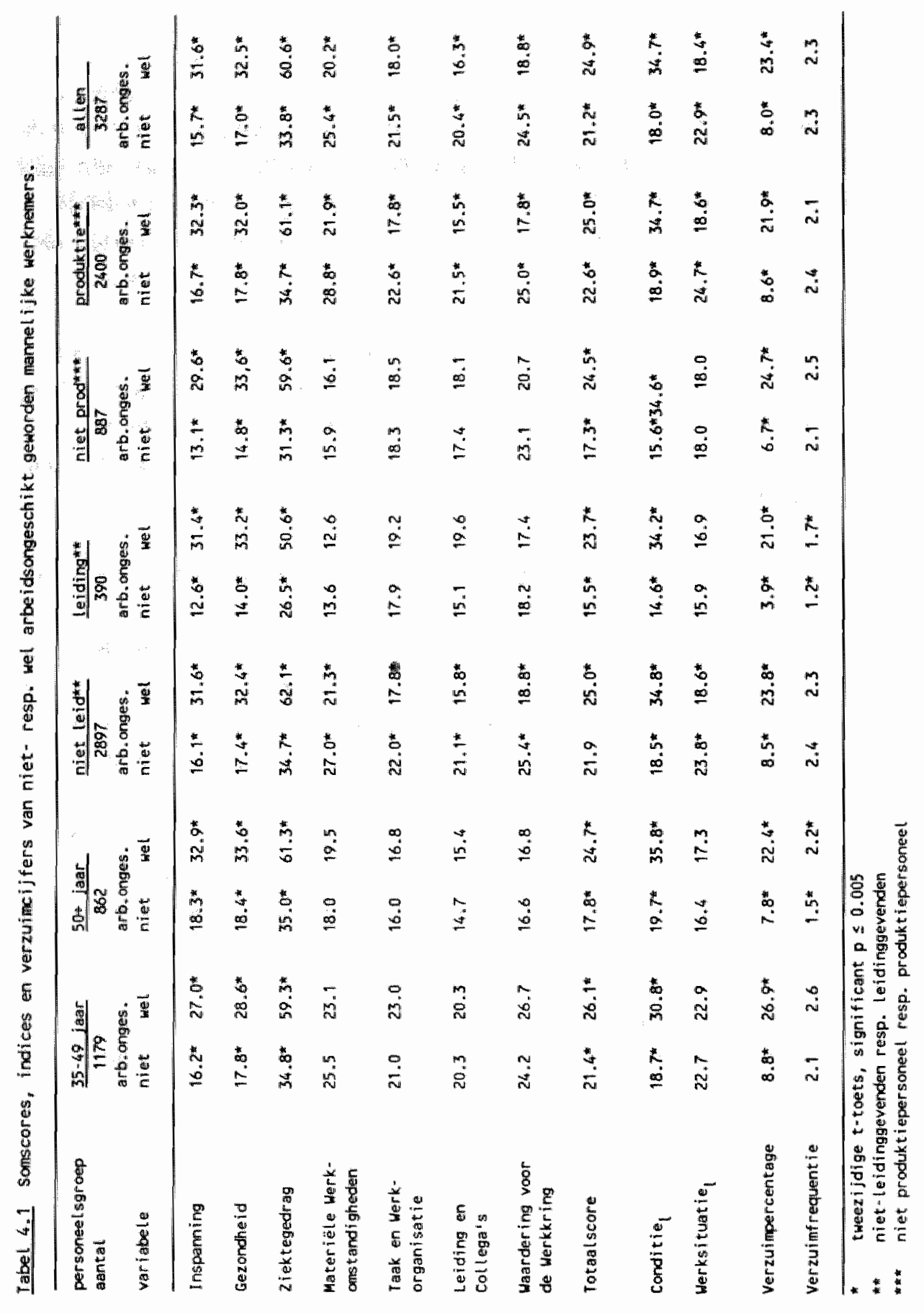


Te concluderen valt dat er binnen de verklarende variabelen een aantal goede candidaat-voorspellers van arbeidsongeschiktheid zijn, die binnen elk van de groepen werknemers verschillen tussen wel- en niet-arbeidsongeschikten vertonen. Dit zijn de somscores Inspanning, Gezondheid en Ziektegedrag, de index Conditie $_{l}$, het verzuimpercentage en eventueel de totaalscore. De boodschap uit tabel 4.1 is: voorspellers van arbeidsongeschiktheid zijn de index Conditie (en zijn samenstellende delen) en het verzuimpercentage. Deze vijf variabelen zullen hier verder worden behandeld, de andere blijven wat betreft arbeidsongeschiktheid verder buiten beschouwing.

\subsubsection{Variabelen in de tijd voor arbeidsongeschiktheid}

De hiervoor geselecteerde variabelen over de jaren voor het arbeidsongeschiktworden zijn vermeld in tabel 4.2. De kolommen zijn de jaren tussen het bedrijfsonderzoek en de arbeidsongeschiktheid, de verschillende variabelen vormen de rijen. De somscores en de index Conditie, zijn eenmalige gegevens die ontleend zijn aan een bedrijfsenquête (zie hoofdstuk 1), deze gegevens hebben elk maar ëen rij. De verzuimgegevens zijn over meerdere jaren, dus longitudinaal beschikbaar, zodat deze in meerdere rijen vermeld zijn ten opzichte van het jaar van de bedrijfsenquete. Dit laatste wordt hier dus als nulpunt aangenomen. De aantallen bij de somscores zijn binnen elke kolom constant, dit is namelijk het aantal werknemers dat deelnam aan de bedrijfsenquete. De aantallen werknemers bij het verzuimpercentage wisselen binnen de kolommen, doordat de verzuimcijfers van de vier bedrijven verschillende perioden beslaan, en voor tabel 4.2 verder geen kalenderjaren, maar jaren t.o.v. het bedrijfsonderzoek zijn geteld. 
Tabel 4.2 Geselecteerde verklarende variabelen van mannelijke werknemers die na het anderzoeks jaar (jaar rul) arbeidsongeschikt werden.

\begin{tabular}{|c|c|c|c|c|c|c|c|c|c|c|}
\hline \multirow{2}{*}{$\begin{array}{l}\text { Jaar na onder zoek } \\
\text { varlabel }\end{array}$} & \multicolumn{2}{|c|}{1} & \multicolumn{2}{|c|}{2} & \multicolumn{2}{|c|}{3} & \multicolumn{2}{|l|}{4} & \multicolumn{2}{|c|}{5} \\
\hline & gem & m & get & in & gem & $n$ & $\operatorname{sen}$ & $n$ & gem & $n$ \\
\hline Inspenning & 33.2 & 121 & 31.8 & 67 & 23.1 & 58 & 29.0 & 27 & 35.0 & 39 \\
\hline Gezondhe $d$ & 34.9 & 121 & 32.7 & 67 & 28.2 & 58 & 34.7 & 27 & 31.5 & 39 \\
\hline 2 ektegedrag & 65.7 & 121 & 64.2 & 67 & 52.6 & 58 & 52.8 & 27 & 56.4 & 39 \\
\hline 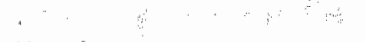 & & & & & & & & & & \\
\hline Totinal score & 25.7 & 121 & 25.0 & 67 & 21.3 & 58 & 24.6 & 27 & 26.3 & 39 \\
\hline Conditiel & 37.1 & 121 & 35.2 & 67 & 27.5 & 58 & 34.2 & 27 & 34.8 & 39 \\
\hline Verzuimpercentage $-4 \mathrm{jr}$ & 11.9 & $5 B$ & 8.7 & 19 & 17.1 & 15 & 11.2 & 12 & 4.5 & 13 \\
\hline Verzulimpercentage $-3 \mathrm{jr}$ & 11.5 & 58 & 11.5 & 19 & 14.9 & 15 & 12.0 & 12 & 4.3 & 13 \\
\hline Verzuimpercentage $-2 \mathrm{jr}$ & 15.0 & 86 & 14.2 & 45 & 12.9 & 36 & 6.3 & 9 & 3.2 & 9 \\
\hline Verzuimpercentage -1 ir & 24.2 & 192 & 17.0 & 100 & 14.4 & 66 & 12.9 & 37 & 11.7 & 47 \\
\hline Verzuimpercentage $0 \mathrm{jr}$ & 35.8 & 168 & 19.6 & 105 & 13.9 & 74 & 14.8 & 40 & 12.5 & 52 \\
\hline Verzuinpercentage +1 jr & 14.5 & 44 & 45.3 & 105 & 17.3 & 74 & 13.5 & 40 & 13.2 & 51 \\
\hline Verzuinpercentage +2 Ir & $\cdots$ & $\cdots$ & 14.3 & 19 & 53.1 & 47 & 25.4 & 40 & 15.1 & 54 \\
\hline Verzuimpercentage +3 ir & $\cdots$ & $\ldots$ & $\cdots$ & $\cdots$ & $\cdots$ & -- & 39.4 & 40 & 15.2 & 51 \\
\hline
\end{tabular}

* gem en $n$ staan vooir gemiddelde respectievelijk aantal; verzuimpercentage -4 jr betekent vier jaar voor het bedrijfsonderzoelk enz.

De aantallen nieuwe arbeidsongeschikten die deelnamen aan het bedrijfsonderzoek nemen in de jaren na het bedrijfsonderzoek (dus horizontaal) af van 121 in het eerste tot 27 en 39 in het vierde respectievelijk vijfde jaar. Deze afname werd al in paragraaf 3.9.1 gesignaleerd. Daar ging het echter om alle werknemers; omdat hieronder mede gebruik wordt gemaakt van somscores, dus van enquete-gegevens uit de VAG, is de groep hier beperkt tot de respondenten wan het bedrijfsonderzoek. Door deze beperking dalen sommige aantallen werknemers in tabel 4.2 tot zeer lage waarden (verzuimpercentage twee tot vier jaar voor het bedrijfsonderzoek bij arbeidsongeschiktheid drie tot vijf jaar daarna). Overigens heeft het verzuimpercentage twee en drie jaar na het bedrijfsonderzoek hier en daar logischerwijs geen enkele waarneming.

De verwachting op grond van de literatuur was (paragraaf 2.5.1) dat werknemers die dichter bij hun arbeidsongeschiktheid staan, meer verzuim en problemen hebben dan degenen die daar verder van af staan. Dit betekent dat in tabel 4.2 scores en verzuim lager moeten zijn naarmate de tijd tussen bedrijfsonderzoek 
en optreden van arbeidsongeschiktheid langer is; de cijfers moeten van links naar rechts dalen.

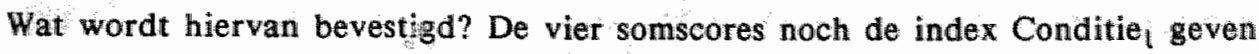
een overtuigende daling te zien. Het verzuimpercentage doet dat voor een deel wel en dit steunt onze verwachting.

Tabel 4.2 kan horizontaal en verticaal beschouwd worden. De horizontale beschouwingswijze geldt voor alle variabelen, voor de somscores zowel als voor het verzuimpercentage. De vraag is hierbij telkens: zijn er, gegeven een bepaalde variabele, verschillen tussen de werknemers die éen of meer jaar na het bedrijfsonderzoek arbeidsongeschikt werden? Verticaal kan allen het verzuimpercentage bezien worden omdat dit geen eenmalig gegeven is (zoals de VAG-somscores), maar een gegeven dat over een reeks jaren (longitudinaal) beschikbaar is. De vraag bij een verticale beschouwing is: zien we bij werknemers die een bepaalde tijd na het bedrijfsonderzoek arbeidsongeschikt werden een toename in het verzuimpercentage.

Eifguur 4.1 Verzuimpercentage per Jaar ten opzichte van het tijdstip wan onderzoek van mannel $i j k e$ werknemers die arbeidsongesichlikt werden

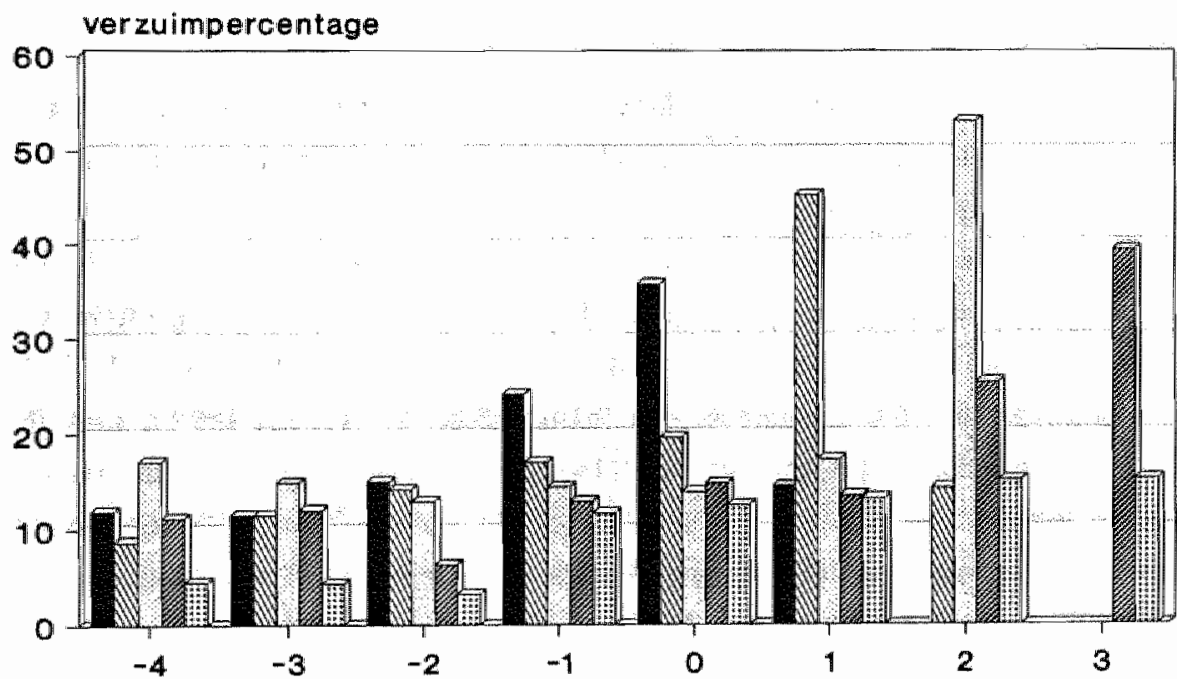

jaar van verzuimpercentage tov bedr. onderzoek

- 1 jar 2 jaar $\square 3$ jaar 4 jaar 5 jaar

arbeidsongeschik theid in Jaar na onderzoek

* Aantallen zie tabel 4.2 
Het verzuimpercentage blijkt over het algemeen te stijgen vanaf een betrekkelijk laag niveau tot aan het jaar van vertrek. Dit percentage is alleen in twee gevallen lager dan het jaar tevoren (nl. bij verzuimpercentage +1 jaar/l jaar na onderzoek en verzuimpercentage +2 jaar $/ 2$ jaar na onderzoek). Die toename is het duidelijkst in de grafieken " $1 \mathrm{t} / \mathrm{m} 4$ jaar na onderzoek'. Het betekent een bevestiging voor het uitgangspunt, dat het proces van arbeidsongeschikt-worden gepaard moet gaan met een toename in het verzuimpercentage.

Dat eenzelf de toename niet in de somscores te zien is, zoals aan het begin van deze paragraaf vermeld werd, ligt aan het feit dat deze op een eenmalig (nietlongitudinaal) onderzoek gebaseerd zijn. Elke groep bij de somscores en de index Conditie is gebaseerd op een andere groep werknemers. Deze groepen hebben geen werknemers gemeen, zodat de invloed van de individuele verschillen op het jaargemiddelde hier groot is. De aantallen per jaarklasse zijn te laag om te verwachten toenamen, die wèl bij het verzuimpercentage te zien zijn, ook in de somscores te kunnen onderscheiden.

\subsubsection{Arbeidsongeschiktheid; voorspellend vermogen per variabele}

\section{Incidentiedichtheidsratio's}

Om thet voorspellend vermogen per variabele vast te stellen wordt gebruik gemaakt van de incidentiedichtheidsratio (IDR). Deze geeft aan (zie paragraaf 3.11), hoeveel meer kans op vertrek een werknemer met een hoge score heeft dan lemand met een lage score. Het is dus een kansverhouding en deze hangt onder meer af van de gekozen grens tussen lage en hoge scores. Deze grenswaarden zijn voor tabel 4.3 bij benadering telkens $10 \%$ hoger gesteld, vanaf de $10 \%$ lagaste tegenover de $90 \%$ hoogste scores (angegeven als 10/90) tot en met de laagste $90 \%$ tegenover de hoogste $10 \%(90 / 10)$. De precieze ligging van de grenswaarden is vermeld in bijlage 5 . Daar blijkt, dat de verzuimfrequentie en de somscores Inspanning en Zilektegedrag slechts een klein aantal waarden aannemen, zodat daar grotere stappen dan $10 \%$ genomen moeten worden.

De IDR's bij de verschillende groepen liggen wat betreft arbeidsongeschiktheid zoals aangegeven in tabel 4.3. De gegevens zijn in tabelvorm en niet in grafiek 
weergegeven, omdat de IDR's als functie van de grenswaarde niet tén regellmatig patroon vertonen, zodat er geen typische grafiek op gebaseerd kan worden.

Tabel 4.3 Incidentiedichtheidsrations (IDR's) van zes variabelen bil arbeidsonge schik theid, mannel ijke werknemers

\begin{tabular}{|c|c|c|c|c|c|c|c|c|}
\hline aantal & grens & $\begin{array}{l}35-49 \\
\text { Jaar } \\
1179\end{array}$ & $\begin{array}{l}50 * \\
\text { Jaar } \\
862\end{array}$ & $\begin{array}{l}\text { let. } \\
\text { ding } \\
390\end{array}$ & $\begin{array}{l}\text { niet - } \\
\text { leid. } \\
2897\end{array}$ & $\begin{array}{l}\text { pro- } \\
\text { dukt } \\
2400\end{array}$ & $\begin{array}{l}\text { nidet: } \\
\text { prod. } \\
\text { Ba? }\end{array}$ & $\begin{array}{l}\text { ta: } \\
\text { tala } \\
3287\end{array}$ \\
\hline & $28 / 72$ & 1.85 & 6.01 & 3.93 & 4.70 & 5.61 & 3.28 & $4.5 \pi$ \\
\hline Inspian:" & $46 / 54$ & 2.53 & 4.28 & 5.27 & 3.99 & 4.58 & 3.51 & 4.12 \\
\hline ming & $60 / 40$ & 2.26 & 3.85 & 6.63 & 3.80 & 4.06 & 4.28 & 4.05 \\
\hline \multirow[t]{5}{*}{ 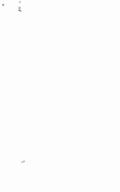 } & $80 / 20$ & 2.78 & 3.32 & 4.58 & 4.35 & 4.10 & 5.59 & 4.35 \\
\hline & $86 / 14$ & 3.48 & 3.04 & 5,34 & 4.11 & 3.79 & 6.04 & 4.20 \\
\hline & $20 / 80$ & 3.31 & 5.51 & 4.73 & 5.42 & 4.25 & 9.51 & 5.24 \\
\hline & $32 / 68$ & 2.51 & 6.3 .2 & 6.37 & 5.35 & 4.38 & 10.54 & 5.45 \\
\hline & $41 / 59$ & 3.34 & 7.08 & 5.99 & 5.93 & 5.13 & 8.61 & 5.89 \\
\hline diezond- & $50 / 50$ & 2.92 & 5.94 & 4.85 & 5.56 & 5.07 & 6.58 & 5.43 \\
\hline \multirow[t]{5}{*}{ heid } & $57 / 43$ & 2.53 & 5.23 & 3.96 & 5.23 & 4.52 & 6.59 & 6.59 \\
\hline & $70 / 30$ & 3.06 & 4.48 & 4.43 & 4.67 & 4.26 & 5.87 & 4.62 \\
\hline & $80 / 20$ & 2.99 & 4.05 & 6.92 & 4.34 & 4.30 & 5.52 & 4.55 \\
\hline & $90 / 10$ & 3.35 & 3.16 & 6.10 & 380 & 3.31 & 7.25 & 4.00 \\
\hline & $32 / 68$ & 4.04 & 4.87 & 2.70 & 5,06 & 5.40 & 3.07 & 4.37 \\
\hline ziekte- & $54 / 46$ & 3.26 & 4.31 & 4.54 & 4.02 & 3,96 & 4.32 & 4.044 \\
\hline \multirow[t]{5}{*}{ gedrag. } & $77 / 23$ & 4.20 & $4 \ldots 29$ & 4.36 & $\sin 11$ & 4.82 & 5.54 & $4 \ldots 98$ \\
\hline & $93 / 07$ & 4.05 & 3.22 & 3.37 & 497 & 4.01 & 7.26 & 477 \\
\hline & $08 / 92$ & 3.94 & 22.41 & 5.68 & 22,94 & 18.78 & 9.7 & 14.22 \\
\hline & $16 / 84$ & 4.38 & 16.16 & 11.36 & 9.81 & 13.17 & 6.92 & 9.97 \\
\hline & $30 / 70$ & 1.99 & 8.40 & 6.12 & 5.87 & 5.43 & 7.14 & 5.85 \\
\hline Condi - & $36 / 64$ & 2.63 & 6.99 & 8.62 & 5,54 & $5.4 B$ & 6.99 & 5.85 \\
\hline \multirow[t]{8}{*}{ tiei } & $47 / 53$ & 3.25 & 6.61 & 5.99 & 6.26 & 5.86 & 7.11 & 6.13 \\
\hline & $57 / 43$ & 3.38 & 6.40 & 4.50 & 6.55 & 6.08 & 6.41 & 6.09 \\
\hline & $74 / 26$ & 3.71 & 4.68 & 5.11 & 5.67 & 5.03 & 6.73 & 5.38 \\
\hline & $80 \times 20$ & 3.80 & 5.31 & 7.54 & 6.10 & 5.54 & 9.11 & 6.22 \\
\hline & $90 / 10$ & 3.30 & 4.50 & 9.20 & 5.51 & 5.29 & 8.09 & 5.81 \\
\hline & $20 / 80$ & 1.61 & 2.12 & 1.20 & 1.33 & 1.12 & 1.82 & 1.30 \\
\hline & $30 / 70$ & 2.10 & 2.37 & 1.79 & 1.76 & 1.54 & 2.34 & 1.74 \\
\hline & $40 / 60$ & 3.37 & 2.28 & 2.34 & 1.94 & 1.72 & 2.78 & 1.96 \\
\hline \multirow[t]{7}{*}{$w x$} & $50 / 50$ & 3.69 & 2.59 & 3.10 & 2.17 & 2.11 & 2.76 & 2.23 \\
\hline & $60 / 40$ & 4.59 & 3.01 & 3.83 & 2.57 & 2.47 & 3.40 & 2.64 \\
\hline & $70 / 30$ & 4.65 & 3.14 & 3.89 & 3.00 & 2.69 & 4.73 & 3.02 \\
\hline & $30 / 20$ & 7.40 & 3.53 & 7.05 & 3.96 & 3.50 & 7.65 & 4.11 \\
\hline & $90 / 110$ & 7.76 & 4.10 & 10.65 & 5.13 & 4.95 & 9.14 & 5.43 \\
\hline & $21 / 79$ & 1.80 & 2.110 & 1.19 & 1.33 & 1.12 & 1.81 & 1.29 \\
\hline & $45 / 55$ & 1.47 & 2.05 & 1.85 & 1.05 & 0.98 & 1.58 & 1.12 \\
\hline \multirow[t]{3}{*}{ VF } & $65 / 35$ & 9.03 & 1.85 & 1.76 & 0.78 & 0.74 & 1.22 & 0.84 \\
\hline & $79 / 21$ & 9.03 & 1.85 & 1.76 & 0.78 & 0.74 & 1.22 & 0.24 \\
\hline & $28 / 21$ & 1.50 & 2.0 .2 & 1.85 & 0.75 & $0.7 \|$ & 1.26 & 0.80 \\
\hline
\end{tabular}


De verzuimfrequentie geeft de laagste IDR's dus deze kan wel- en niet-arbeidsongeschikten slecht onderscheiden. De overige variabelen (Inspanning, Gezondheid, Ziektegedrag, Conditie ${ }_{(}$en verzuimpercentage) komen daar elk ver bovenuit. Een eerste conclusie kan daarom zijn dat alle hier opgevoerde variabelen behalve de verzuimfrequentie een voorspelling van de latere arbeidsongeschiktheid mogelijk maken.

Een tweede verschill in de cijfers van tabel 4.3 is dat de IDR's in de jongste groep (mannelijke werknemers van 35 - 49 jaar) bij de variabelen Inspanning tot en met Conditie, lager zijn dan in de overige groepen werknemers, dus in de jongste groep hebben inspanning, gezondheid en ziektegedrag betrekkelijk weinig met latere arbeidsongeschiktheid te maken. Dit ligt voor de hand want eerder (tabel 3.21) bleek dat het aantal arbeidsongeschikten in deze groep laag is in vergelijking tot de boven-vijftigjarigen. Waar weinig gevallen te voorspellen zijn kan om die reden de IDR niet hoog zijn.

Verder blijkt dat de index Conditie, tot hogere IDR's komt dan de somscores die deel uitmaken van deze index. Met name in de groepen $50+$, niet-leiding en produktie komen hoge waarden voor. Conditie ${ }_{1}$ is dus een betere voorspeller van arbeidsongeschiktheid dan de somscores Inspanning, Gezondheid en Ziektegedrag. Bij de verzuimgegevens is duidelijk dat alleen het verzuimpercentage in aanmerking komt als voorspeller. De IDR's zijn hiervan weliswaar niet zo hoog als bij de index Conditie, , maar ze zijn aanmerkelijk hoger dan bij de verzuimfrequentie. Er zal echter moeten worden nagegaan wat deze IDR's waard zijn in het licht van hun sensitiviteit en specificiteit.

\section{Arbeidsongeschiktheid: sensitiviteit en specificiteit}

De definitie van de begrippen 'sensitiviteit' en 'specificiteit' is gegeven in paragraaf 3.»1. Kort gezegd is in dit onderzoek de sensitiviteit het percentage van de vertrekgevallen die voorspeld worden door een hoge score; de specificiteit is het percentage van de niet-vertrokken werknemers dat voorspeld wordt door een lage score.

De gevonden waarden van de sensitiviteit en de specificiteit voor de voorspelling van arbeidsongeschiktheid bij verschillende grenswaarden in de voorspellende 
variabelen worden gegeven in bijlage 6. Anders dan de IDR's zelf (tabel 4.3) hebben de sensitiviteit en de specificiteit van de IDR's een regelmatig verloop met de hoogte van de grenswaarde, zodoende kunnen hier grafieken van worden gemaakt. Er blijkt, dat de curven een gelijksoortig verloop hebben. Het is daarom niet nodig, alle grafieken te tonen (dat zouden er bij zes variabelen en zeven groepen werknemers tweeënveertig worden, die sterk op elkaar lijken). In plaats van tweeënveertig grafieken geeft figuur 4.2 daarom bij wijze van voorbeeld een duidelijke grafiek, $\mathrm{nl}$, die van Conditie ${ }_{\mathfrak{l}}$ als voorspeller bij de groep mannelijke werknemers van 50 jaar en ouder.

Figur 4.2 Sensitiviteit en specificiteit van de index conditie bil de voorspelling van arbeidsongeschiktheid, mannel ijke werknemers, 50 jatr en auder (nz862)

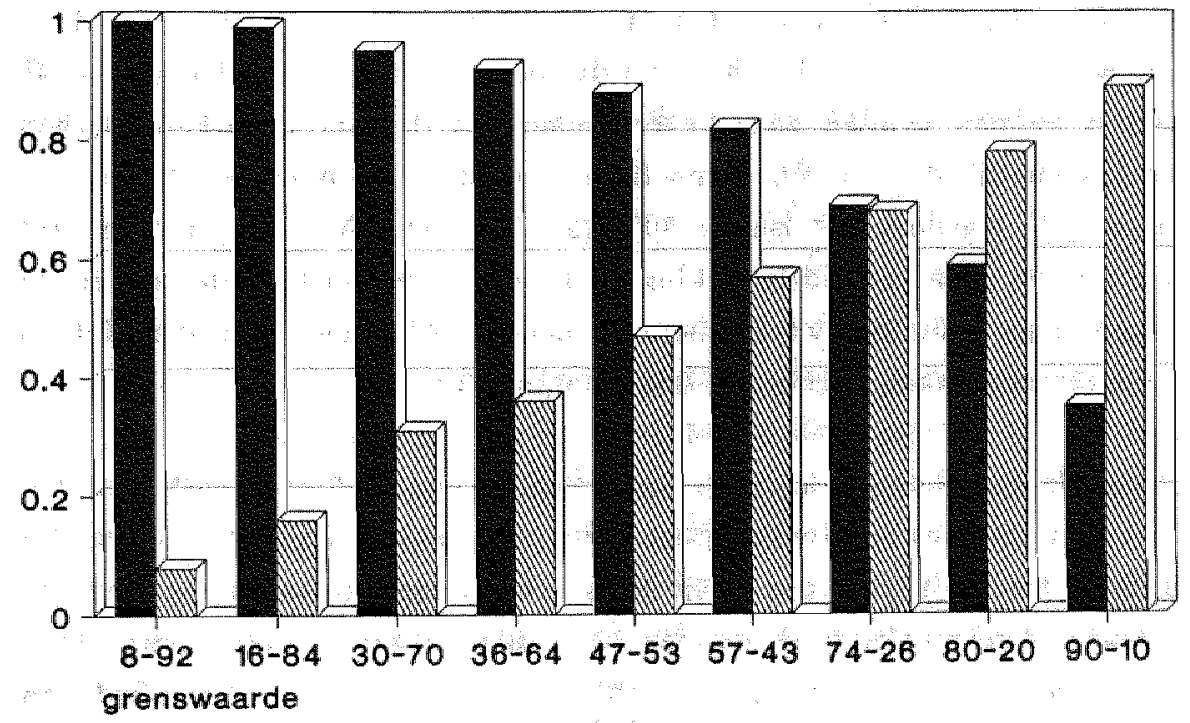

Sensitiviteit Specificiteit

De sensitiviteit is aanvankelijk (bij lage grenswaarden) hoog, pas bij de grenswaarde 47 - 53 (de vertrokkenen worden dan gezocht in de $53 \%$ hoogscoorders), daalt de sensitiviteit onder de 0.90 . De specificiteit verloopt ongeveer spiegelbeeldig ten opzichte van de sensitiviteit, bij lage grenswaarden is de specificiteit gering en deze neemt toe bij de hogere grenswaarden. Bij elke voorspelling zal er daarom een compromis moeten worden gevonden tussen sensitiviteit en specifici- 
teit, want beide blijken niet tegelijk hoog te kunnen zijn. De afweging daarbij wordt behandeld in paragraaf 3.11 en 4.1.5.

\subsubsection{Arbeidsongeschiktheid: voorspelling uit werknemersmeningen en ver- zuimgegevens}

\section{Logistische regressle}

In paragraaf 3.9.1. werd duidelijk dat de aantallen arbeidsongeschikten sterk met de leeftijid toenemen. Verder bleek in de voorgaande paragraaf dat naast de leeftijd ook de index Conditie, en het verzuimpercentage met het latere vertrek door arbeidsongeschiktheid te maken hebben. De vraag ligt daarom voor de hand of het mogelijk is, deze drie variabelen (leeftijd, Conditie ${ }_{l}$ en verzuimpercentage) in een voorspelling mee te laten spelen. Het aantal mogelijkheden om dit te doen is groot, want er zijn verschillende leeftijdsgroepen en grenswaarden die in de voorspellers kunnen worden gelegd. We zullen ons daarom beperken tot een voorbeeld, namelijk dat van alle mannelijke werknemers zonder selectie en van de hoogste $20 \%$ tegenover de laagste $80 \%$ van de scores. Alle werknemers zijn hier gekozen om geen leeftijdsbeperking op te leggen en om terwille van goede schattingen hoge aantallen werknemers te nemen. Als bewerkingstechniek is logistische regressie-analyse gebruikt (zie paragraaf 3.11 ).

We noemen de variabele $y=\log$ odds van arbeidsongeschiktheid, waarbij odds $=$ $p /(1-p)$ als $p$ de kans op arbeidsongeschiktheid is (odds = waarschijnlijkheidsverhouding). De odds zijn dus geen kansverhoudingen tussen twee groepen werknemers die eventueel sterk kunnen verschillen, maar het zijn getransformeerde kansen binnen elke groep; zie eerder: odds $=p /(1-p)$. (Omgekeerd kan men desgewenst uit $p=$ odds $/(1+$ odds $)$ weer de kans $p$ berekenen.) Verder is $x_{1}=$ leeftijd, $x_{2}=$ Conditie $_{1}$ en $x_{3}=$ verzuimpercentage. Het model met alle drie de voorspellers levert de volgende schatting op:

$$
y=-10.38+2.09 x_{1}+1.26 x_{2}+1.10 x_{3}
$$

Het model past echter slecht bij de gegevens, want chi kwadraat $=17.01, \mathrm{df}=8$ en $p=0.03$. De vraag wordt daarom of het wel juist is, drie voorspellers te ge- 
bruiken. Al eerder bleek, dat de leeftijd van de werknemers een sterke samenhang met het optreden van arbeidsongeschiktheid heeft (paragraaf 3.9.1) en verder dat er samenhangen tussen leeftijd en de beide voorspellers Conditie $\mathrm{l}_{\mathrm{l}}$ en $\mathrm{V} \%$ zijn (paragraaf 3.6.5); er zou dus een interactie tussen de drie voorspellers kunnen zijn. Daarom zouden we kunnen nagaan wat binnen elk van de leeftijdsgroepen de voorspellende waarden van Conditie ${ }_{\|}$en verzuimpercentage zijn.

Logistische regressie met deze twee voorspellers binnen de leeftijdsgroepen levert de uitkomsten van tabel 4.4.

Tabel 4.4 Logistische regressie wan arbeidsongeschiktheid op Conditiel en binnen de drie leeftijdsigroepen.

\begin{tabular}{llcll}
\hline groep & vergetijking & chi kwadr. & df & $p$ \\
\hline $16-34$ jaar & $y=-8.00-0.11 x_{2}+2.53 x_{3}$ & 0.77 & 1 & 0.38 \\
$35-49$ jaar & $y=-6.52+0.95 x_{2}+1.44 x_{3}$ & 1.79 & 1 & 0.18 \\
$50+$ jaar & $y=-4.18+1.55 x_{2}+1.04 x_{3}$ & 0.09 & 1 & 0.77 \\
\hline
\end{tabular}

Geen van de chi-kwadraten bereikt hier een sïgnificante waarde, dus er blijkt dat elk van de modellen binnen de leeftijdsgroepen goed past. Verder is duidelijk dat het belang van het verzuimpercentage $\left(x_{3}\right)$ afneemt en dat van de index Conditie $_{\|}\left(x_{2}\right)$ toeneemt met stijgende leeftijd.

Overigens wijken de coëfficiënten van $x_{2}$ en $x_{3}$ in tabel 4.4 sterk af van die bij drie voorspellers; dit betekent (wat al vermoed werd) dat er een interactie tussen leeftijd enerzijds en Conditie, en verzuimpercentage anderzijds is. Dit weer verklaart de uitkomst dat het drie-variabelen-model een slechtere 'fit' heeft dan elk van de twee-variabelen-modellen. Wat deze laatste betekenen in termen van "adds" is aangegeven in tabel 4.5. 

specificiteit in drie leeftijdsgroepen, mannelijke werknemers, tegelijk Condt te

\begin{tabular}{|c|c|c|c|c|c|c|}
\hline \multirow[b]{2}{*}{ leeftidd } & \multirow[b]{2}{*}{$\begin{array}{l}\text { condî- } \\
\text { thei }\end{array}$} & \multirow[b]{2}{*}{$\sqrt{x}$} & \multicolumn{2}{|c|}{ odds: } & \multirow[b]{2}{*}{$\begin{array}{l}\text { sensiti- } \\
\text { vitelt }\end{array}$} & \multirow[b]{2}{*}{$\begin{array}{l}\text { specifi } \\
\text { elteit }\end{array}$} \\
\hline & & & $\begin{array}{l}\text { wararge- } \\
\text { nomen }\end{array}$ & $\begin{array}{l}\text { voor- } \\
\text { speld }\end{array}$ & & \\
\hline $\begin{array}{l}16-34 \text { Jatit } \\
(n=124.6)\end{array}$ & $\begin{array}{l}L^{*} \\
L \\
H \\
H\end{array}$ & $\begin{array}{l}L^{*} \\
H \\
L \\
H\end{array}$ & $\begin{array}{l}0.004 \\
0.043 \\
0.000 \\
0.051\end{array}$ & $\begin{array}{l}0.003 \\
0.048 \\
0.003 \\
0.043\end{array}$ & $\begin{array}{l}0.62 \\
0.75 \\
0.75\end{array}$ & $\begin{array}{l}0.78 \\
0.85 \\
0.96\end{array}$ \\
\hline $\begin{array}{l}35-49 \text { jaar } \\
(r=1179)\end{array}$ & $\begin{array}{l}L \\
L \\
H\end{array}$ & $\begin{array}{l}\mathbb{L} \\
H \\
L \\
H\end{array}$ & $\begin{array}{l}0.014 \\
0.087 \\
0.058 \\
0.147\end{array}$ & $\begin{array}{l}0.016 \\
0.068 \\
0.042 \\
0.176\end{array}$ & $\begin{array}{l}0.73 \\
0.49 \\
0.30\end{array}$ & $\begin{array}{l}0.71 \\
0.81 \\
0.93\end{array}$ \\
\hline $\begin{array}{l}50+\text { jaar } \\
(n=862)\end{array}$ & $\begin{array}{l}\text { L } \\
\text { L } \\
H \\
H\end{array}$ & $\begin{array}{l}L \\
H \\
L \\
H\end{array}$ & $\begin{array}{l}0.202 \\
0.604 \\
0.986 \\
2.630\end{array}$ & $\begin{array}{l}0.205 \\
0.581 \\
0.966 \\
2.737\end{array}$ & $\begin{array}{l}0.74 \\
0.60 \\
0.30\end{array}$ & $\begin{array}{l}0.67 \\
0.78 \\
0.94\end{array}$ \\
\hline
\end{tabular}

$L=$ laag, onderste $80 \%, H=$ hoog, bovenste $20 \%$; zie bijlage 5 voor de ligging van de grenzen

* Bij respectievelijk LL tegenover rest, LL en LH tegenower rest en LL, LH en HL tegenover $\mathrm{HH}$.

Aanschouwelijker dan tabel 4.4 geeft tabel 4.5 aan, dat de voorspelde odds een goede benadering zijn van de waargenomen odds. De voorspelling op basis van Conditie, en $V \%$ binnen de leeftijdsgroep is daarom tamelijk realistisch. In tabel 4.5 is duidelijk dat de kans op WAO ook in termen van de odds globaal toeneemt met stijgende leeftijd en (zoals al werd vermeld) dat de voorspellende kracht van het verzuimpercentage met toenemende leeftijd terugloopt met toenemende leeftijd.

\section{Sensitiviteit en specificiteit}

Ook hier, bij de voorspelling op basis van twee variabelen, is een belangrijke praktische vraag, die nar de sensitiviteit en de specificiteit. Voor de overzichtelijkheid beperken we ons tot de vier groepen (LL tot en met HH) per leeftijdsgroep, zie tabel 4.5 .

Wat eerder gevonden werd bij de voorspelling met afzonderlijke variabelen (paragraaf 4.1 .3$)$ geldt ook hier: naarmate het criterium hoger ligt, neemt meestal de 
sensitiviteit af en neemt de specificiteit toe op de manier van figuur 4.2. Het is niet moeilijk een hoge sensitiviteit te bereiken, maar dat gaat ten koste van de specificiteit. Hier ligt echter de situatie gunstiger dan bij de voorspelling met én variabele (bijlage 6), want kiest men als criterium $L L$ tegenover de andere combinaties ( $\mathrm{LH} \mathrm{t} / \mathrm{m}$ HH) dan zijn sensitiviteit en specificiteit van gelijke orde van grootte en liggen, afhankelijk van de leeftijdsgroep, in de buurt van .70 tot 90 .

Wanneer men zowel beschikt over verzuimgegevens (V\%) als VAG-gegevens (Conditie ${ }_{l}$ ), is het daarom aan te bevelen, beide gegevens in de voorspelling te betrekken. Dit omdat dan de specificiteit hoger is dan bij gebruik van VAGgegevens alleen (vergelijk paragraaf 4.1.3).

\subsubsection{Arbeidsongeschiktheid en lange VAG: discussie}

De drie belangrijkste punten die besproken moeten worden in het licht van de resultaten zijn de overeenstemming met de literatuur, de mogelijkheden tot praktische voorspelling van arbeidsongeschiktheid en de validiteit van de verklarende variabelen. Het is niet te vermijden, dat enkele eerdere conclusies hieronder herhaald worden.

\section{Overeenstemming met de literatuur}

De literatuur (paragraaf 2.2 en 2.5.1) schildert de arbeidsongeschikte vaak af als een oudere werknemer, die lichamelijke arbeid heeft verricht in een niet-leidinggevende positie. Dat het voor een groot deel om oudere werknemers gaat wordt door de resultaten bevestigd; hierop werd al in hoof dstuk 3 gewezen. Dat arbeidsongeschikten meestal handwerkers zijn, is wel in absolute zin bevestigd, maar naar verhouding bleken de aantallen arbeidsongeschikten in niet-produktieafdelingen en bij leidinggevenden zeker niet lager te zijn dan in produktieafdelingen en bij niet-leidinggevenden. Hoe kan dit? Misschien wordt in de literatuur meer op absolute aantallen dan op percentages arbeidsongeschikten gelet; allicht imponeren de hoge aantallen uitwoerenden meer dan de lage aantallen leidinggevenden. Er is echter een sterkere verklaring. Uit CBS-cijfers blijkt, dat de meeste ondernemingen klein zijn; het aantall eenmansbedrijven zonder werknemers was in 1988 ruim 250.000 , met $1-5$ werknemers ruim 150.000 en dan gat het naar beneden: 5-10 werknemers ruim 31.000 bedrijven, 10-100 werknemers 
goed 37.000 en boven de 100 werknemers ruim 4000 bedrijven (CBS, 1987). Dat betekent dat veruit het grootste aantal leidinggevenden in de kleine bedrijven voorkomt. Laten we veronderstellen dat de verhouding tussen aantallen leidinggevenden en uitvoerenden in de vijf klassen hierboven als volgt liggen: 0 , 1:4, 1:9, 1:16 en 1:20 (de verhouding wordt steeds kleiner naarmate de onderneming groter is). Dit betekent, dat er in totaal ruim 530.000 leidinggevenden zijn, van wie er alleen al in eenmansbedrijven ruim 250.000 voorkomen en in de bedrijven met $1-5$ werknemers ongeveer 113.000 . Samen zijn dit er 363.000 , dat wil zeggen $68 \%$ van alle leidinggevenden. De meeste van deze leidinggevenden in kleine bedrijven vallen onder de AAW en niet de WAO (die een werknemersverzekering is). Dat relatief veel uitwoerenden ten opzichte van de leidinggevenden in de WAO terecht komen is een gevolg van de verschillen in verzekerde populaties van WAO en AAW. Kijkt men alleen naar de WAO en niet naar de AAW, dan lijkt het alsof vooral uitvoerenden arbeidsongeschikt worden, maar dit is schijn, en een gevolg van eenzijdig naar de WAO kijken.

Dat volgens de literatuur de arbeidsinspanning een belangrijke voorloper van arbeidsongeschiktheid kan zijn, werd bevestigd. De somscore Inspanning gaat duidelijk samen met de kans op arbeildsongeschiktheid. Verder is duidelijk dat de somscores Gezondheid en Ziektegedrag bij de meeste groepen later arbeidsongeschikten hoog zijn, evenals de verzuimpercentages.

In de literatuur wordt de toename in de fysieke en mentale arbeidsinspanning, die tot een verminderd prestatievermogen leidt, soms toegeschreven aan gebrek aan herstelmogelijkheden. We zagen, dat de toename van de problemen met gezondheid en inspanning in alle groepen werknemers optreedt, zodat deze verklaring over de hele linie door de gegevens bevestigd wordt. Het is gezien de resultaten aannemelijk dat het prestatievermogen achteruitgaat, onafhankelijk van de taakeisen. Blijven deze laatste gelijk, dan kan de werknemer op een gegeven tijdstip zijn werkzaamheden niet meer aan. Hij meldt zich ziek waarna er, als er geen geschikte vervangende arbeid gevonden wordt, een proces op gang komt dat leidt tot de uiteindelijke arbeidsongeschiktheid. De resultaten spreken dus tegen de slijtage-opvatting en voor de achteruitgangsopvatting van onder meer Baart (1973), en De Boorder (1979) en voor de modellen van Meijman (1988) en Kompier (1988); zie paragraaf 2.2.7. 
Een derde element dat vaak in de literatuur genoemd wordt, zijn de fysieke, sociale en organisatorische werkomstandigheden (zie bijvoorbeeld Schellart e.a.; 1990a). Deze zouden bijdragen aan het proces van arbeidsongeschikt-worden. In termen van het onderhavige onderzoek betekent dit, dat de somscores Materiëlle Werkomstandigheden tot en met Waardering voor de Werkkring positief met arbeidsongeschiktheid moeten samenhangen, dus met hogere scores bij de latere arbeidsongeschikten en met hoge incidentiedichtheidsratio's. Hier nu is geen sprake van; voor zover er verschillen zijn (zie tabel 4.1) liggen de verschillen andersom, met lagere waarden op deze onderwerpen bij de later arbeidsongeschikten. De oorzaak hiervan wordt gegeven in paragraaf 3.6.5: de somscores Materiēle Werkomstandigheden tot en met Waardering Werkkring nemen af met stijgende leeftijd, dus er is een relatieve toename in de waardering voor deze werkaspecten met toenemende leeftijd. De arbeidsongeschikten zijn vooral oudere werknemers met relatief gunstige werkomstandigheden (zie paragraaf 3.6 .5 en de volgende subparagraaf), zodat ook de arbeidsongeschikten lage gemiddelden op deze somscores hebben, dus een naar verhouding hoge waardering voor de werkomstandigheden.

Waar de literatuur meldt dat arbeidsongeschiktheid samenhangt met de arbeidsomstandigheden is gezien het voorgaande waarschijnlijk sprake van een misverstand. Dit misverstand kan ontstaan door de interpretatie van totaalcijfers, niet gesplitst naar leeftijd; cijfers die meestal positieve correlaties tussen werknemersmeningen m.b.t. der werkomstandigheden en arbeidsongeschiktheid opleveren. (De grootste aantallen arbeidsongeschikten komen immers uit de onderste hiërarchische laag, waar globaal de minst gunstige arbeidsomstandigheden aanwezig zijn.) Splitsing naar leeftijd geeft echter, zoals de resultaten uitwijzen, een heel ander en waarschijnlijk juister beeld.

De resultaten van het onderzoek laten dus zien dat de werkomstandigheden, zoals gemeten met de $\mathrm{VAG}$, geen directe invloed op het proces van arbeidsongeschiktworden hebben. Dat betekent dus dat er sprake is van een indirect verband tussen de arbeidsomstandigheden en arbeidsongeschiktheid. Die invloed loopt via de arbeidsbelasting en het verwerkingsvermogen (zie paragraaf 2.2.7), en komt pas

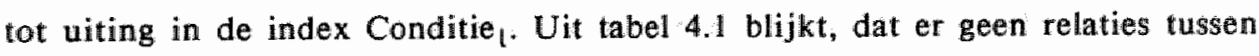
de somscores Materiële Werkomstandigheden $t / m$ Waardering Werkkring en ar- 
beidsongeschiktheid zijn, maar tabel 3.8 laat zien dat de somscores binnen de index Conditie, (Inspanning, Gezondheid en Ziektegedrag) wel degelijk samenhangen met de scores binnen de index Werksituatie, (Materiële Werkomstandigheden $t / m$ Waardering Werkkring). Er is blijkbaar geen directe invloed slechte arbeidsomstandigheden - -> arbeidsongeschktheid, maar wel een indirecte: slechte arbeidsomstandigheden $\rightarrow-\rightarrow$ problemen met werk en gezondheid $\rightarrow->$ arbeidsongeschiktheid. Het bestaan van deze indirecte invloed kan met de beschikbare gegevens niet bewezen worden; een dergelijk onderzoek zou tientallen jaren moeten duren. Wel vallen de resultaten goed te rijmen met zo een indirecte invloed. Hoewel de werksituatie niet meespeelt in de voorspelling van arbeidsongeschiktheid, is het aannemelijk dat de expositie aan de werksituatie van de jonge werknemers op lange termijn bijdraagt aan hun latere gezondheidsklachten en arbeidsongeschiktheid.

Als die invloed bestaat, loopt hij via de arbeidsbelasting en het verwerkingsvermogen (zie paragraaf 2.2 .7 ), en komt in dit onderzoek tot uiting in de index Conditie ${ }_{1}$. Waar het in termen van de beschikbare gegevens als voorspellers om gaat zijn de somscores Inspanning, Gezondheid en Ziektegedrag, de index Conditie, die deze samenvat, en het verzuimpercentage. (Wat de korte VAG betreft geldt hetzelfde voor de index Conditie ${ }_{k}$; zie hoofdstuk 5.)

In paragraaf 2.2.7 werd het onderzoek van Astrand e.a. (1988) vermeld, waarin werknemersmeningen uit de Cornell Medical Index vrijwel geen voorspellend vermogen hadden ten aanzien van arbeidsongeschiktheid. In het voorafgaande is echter gebleken, dat meningen die gevraagd worden met de VAG wat sommige onderwerpen betreft wel degelijk voorspellende waarde hebben. De VAG vraagt blijkbaar naar voor arbeidsongeschiktheid meer relevante zaken dan de Cornell Medical Index en de verdere vragen van Astrand e.a. Hun conclusie, dat meningen van werknemers in het algemeen geen voorspellers van arbeidsongeschiktheid kunnen zijn, is onjuist. Sommige meningen zijn relevant en geven aanknopingspunten voor voorspelling van arbeidsongeschiktheid.

\section{Voorspelbaarheid van arbeidsongeschik theid}

Sommige variabelen bleken wel, andere niet samen te hangen met arbeidsongeschiktheid (tabel 4.1). Wat de VAG betreft bleken klachten op de somscores 
Inspanning, Gezondheid en Ziektegedrag, en in mindere mate ook de VAG korte versie en de totaalscore verband te houden met latere arbeidsongeschiktheid. A1 deze scores zijn bij de arbeidsongeschikten hoger dan bij de vergelijkingsgroep. De overige somscores (Materiële Werkomstandigheden, Taak en Werkorganisatie, Leiding en Collega's en Waardering voor de Werkkring bleken slechts in enkele groepen werknemers met arbeidsongeschiktheid samen te hangen, maar in omgekeerde richting, want hierbij bleken de aanstaande arbeidsongeschikten lagere gemiddelde scores te hebben dan de niet-arbeidsongeschikten.

De verklaring hiervan, zoals al kort vermeld, is te vinden in paragraaf 3.6.5. Er zijn twee groepen variabelen, nl. één die stijgt (toename problemen) met de leeftijd (Inspanning, Gezondheid, Ziektegedrag en het verzuimpercentage) en een die daalt (afname problemen) met toenemende leeftijid (de overige scores en verzuimfrequentie). Deze twee groepen variabelen zijn daardoor onderling negatief gecorreleerd, en dat betekent dat bij de gevonden positieve verbanden tussen de eerste groep en arbeidsongeschiktheid er negatieve verbanden te verwachten zijn tussen de overige variabelen en arbeidsongeschiktheid. Dit blijkt in enkele groepen werknemers het geval en daar kan toch niet aangenomen worden, dat weinig problemen met de werkomstandigheden en dergelijke leidlen tot latere arbeidsongeschiktheid. Deze verbanden zijn schijnverbanden door de genoemde tegengestelde samenhangen van de twee groepen variabelen met leeftijd.

In tabel 4.1 bleek verder de totaalscore van de VAG well in verwachte richting te verschillen tussen wel- en niet-arbeidsongeschikten, maar de verschillen bleken hier niet zo groot te zijn als bij de eerste drie afzonderlijke somscores (Inspanning, Gezondheid, Ziektegedrag). De verklaring hiervan ligt voor de hand gezien het voorgaande: de totalscore en de korte versie zijn mengsels van goed differentierrende en in omgekeerde richting minder goed differentiërende variabelen. Hun voorspellend vermogen wordt verminderd doordat er voor arbeidsongeschiktheid irrelevante informatie in aanwezig is. Er kon om die reden een aantal somscores als voorspeller afvallen. Van de beide verzuimgegevens bleek verder de verzuimfrequentie een wat zwakkere relatie te hebben met arbeidsongeschiktheid te zijn dan het verzuimpercentage, maar beide verzuimmaten zijn als voorspeller geprobeerd. Zodoende is er gekeken naar een selectie van veelbelovende 
candidaat-voorspellers, namelijk de somscores Inspanining, Gezondheid en Ziektegedrag, de index Conditie ${ }_{l}$, thet verzuimpercentage en de verzuimfrequentie.

De incidentiedichtheidsratio"s van deze variabelen (tabel 4.3) liggen in het algemeen boven een waarde van 3 , behalve bij de verzuimfrequentie. De hoogste

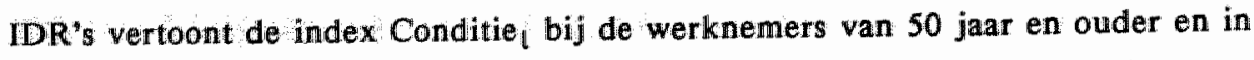
de groep niet-leidinggevenden. De index Conditie $_{\mathfrak{l}}$ loopt per groep werknemers gemiddeld van 3.4 tot 9.1 en afgezien van de groep $35-49$ jaar zelfs van 7.1 tot 9.1. Er zijn uit de literatuur geen andere voorspellingen van arbeidsongeschiktheid als vergelijkingsmaatstaf voor deze resultaten voorhanden. Een benaderende maatstaf is misschien Appels (1987); hij vond met de Maastrichtse Vragenlijst die vitale uitputting meet, relatieve risico's van 3.5 tot 4.4 voor het krijgen van een hartinfaret binnen vier jaar. Het gaat bij Appels dus om een ander risico en verder zijn zijn relatieve risico's niet identiek met onze IDR's, maar ze geven wel de orde van grootte van een goede voorspelling. Die IDR's zijn in doorsnee wat hoger dan de relatieve risico's van Appels en de conclusie is daarom dat de VAG een goede voorspelling van arbeidsongeschiktheid mogelijk maakt.

Is het daarmee zonder meer mogelijk, goede individuele voorspellingen ten aanzien van arbeidsongeschikt-worden te doen? In het antwoord hierop is rekening gehouden met twee verdere aspecten, $n$ l. de sensitiviteit en de specificiteit (zie paragraaf 3.11 voor hun betekenis). Sturmans (1984) stelt dat voor de toepassing in bevolkingsonderzoek idealiter zowel de sensitiviteit als de specificiteit hoog moet zijn. Aan deze eis voldoen de voorspellingen hier niet, maar dat was ook moeilijk te verwachten, aangezien de voorspellingen gebaseerd zijn op metingen met een instrument (de VAG) en op verzuimcijfers die geen van beide voor zulk bevolkingsonderzoek bedoeld zijn. Als men zijn grenzen in de voorspellers maar laag genoeg stelt, komen alle arbeidsongeschikten in de hoogscorende groep terecht. De keerzijde hiervan is, dat zo maar weinig van de blijvers als blijver worden aangemerkt, dus dan is de sensitiviteit hoog, maar de specificiteit laag. Stelt men om die reden de grens veel hoger, dan daalt de sensitiviteit (llang niet alle arbeidsongeschikten worden nog aangewezen door de voorspeller) en stijgt de specificiteit (er worden meer blijvers als zodanig aangemerkt). Het is duidelijk dat er hier een compromis (zie $3.1 \rrbracket$ en 4.1.3) gevonden moet worden, want anders zou men de kans lopen dat veel van de schaarse middelen van bijvoor- 
beeld een bedrijfsgeneeskundige dienst, worden aangewend voor werknemers die het niet nodig hebben, respectievelijk dat zorg onthouden wordt aan werknemers die deze wel nodig hebben.

Laten we als voorbeeld de voorspelling van arbeidsongeschiktheid in de oudste groep werknemers uit Conditie, en verzuimpercentage nemen (tabel 4.5). Laag (L) betekent ook thier de onderste $80 \%$ van de scores op Conditie, of verzuimpercentage, hoog $(\mathrm{H})$ de bovenste $20 \%$. We kunnen dan kiezen uit drie beslissingen. In het bovenste deel van deze tabel worden weinig toekomstige arbeidsongeschikten over het hoofd gezien (63 van de 239 ), maar bij degenen die wèl aandacht krijgen gebeurt dat vaak ten onrechte (nl. bij 154 van de 330 geselecteerden). Dit laatste is in een situatie met ruime geldmiddelen geen bezwar; alleen zal dit weinig voórkomen. Stelt men daarom zijn maatstaven hoger (midden van tabel 4.6), dan daalt het aantal werknemers aan wie ten onrechte aandacht besteed wordt, maar dit heeft een prijs: het aantal toekomstige arbeidsongeschikten dat niet herkend wordt, stijgt (van 63 naar 95).

In de onderste tabel tensllotte worden de maatstaven zo hoog gesteld (Conditie en verzuimpercentage tegelijk in de hoogste $20 \%$ ), dat nog maar 98 werknemers aandacht krijgen, van wie 71 terecht, maar 27 ten onrechte, terwijl 168 toekomstige arbeidsongeschikten over het hoof worden gezien.

Het is duidelijk de er bij een niet-perfecte voorspelling noodzakelijkerwijs fouten gemaakt worden. Werknemers die het niet nodig hebben, krijgen aandacht; werknemers die wel aandacht nodig hebben, krijgen die niet. Kunnen we daar op technische gronden een advies over geven? De samenhang tussen voorspelling en uitkomst (arbeidsongeschikt of niet) zou een grond kunnen zijn, uitgedrukt in een correlatiecoeffficiènt (Ø). In het bovenste tabelletje van tabel 4.6 is die correlatiecoëfficiënt $\varnothing=0.39$, in het middelste en onderste respectievelijk 0.38 en 0.33. Deze waarden ontlopen elkaar niet veel, dus op deze (technische) grond is er geen goede keuze voor de grenswaarde te maken. 


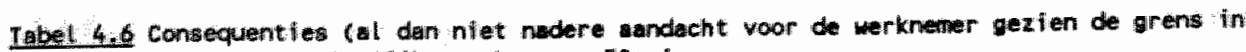
de score), mennellike werknemera 50 - jas

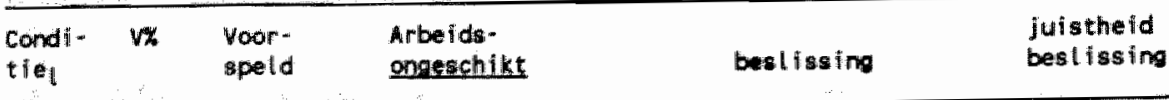

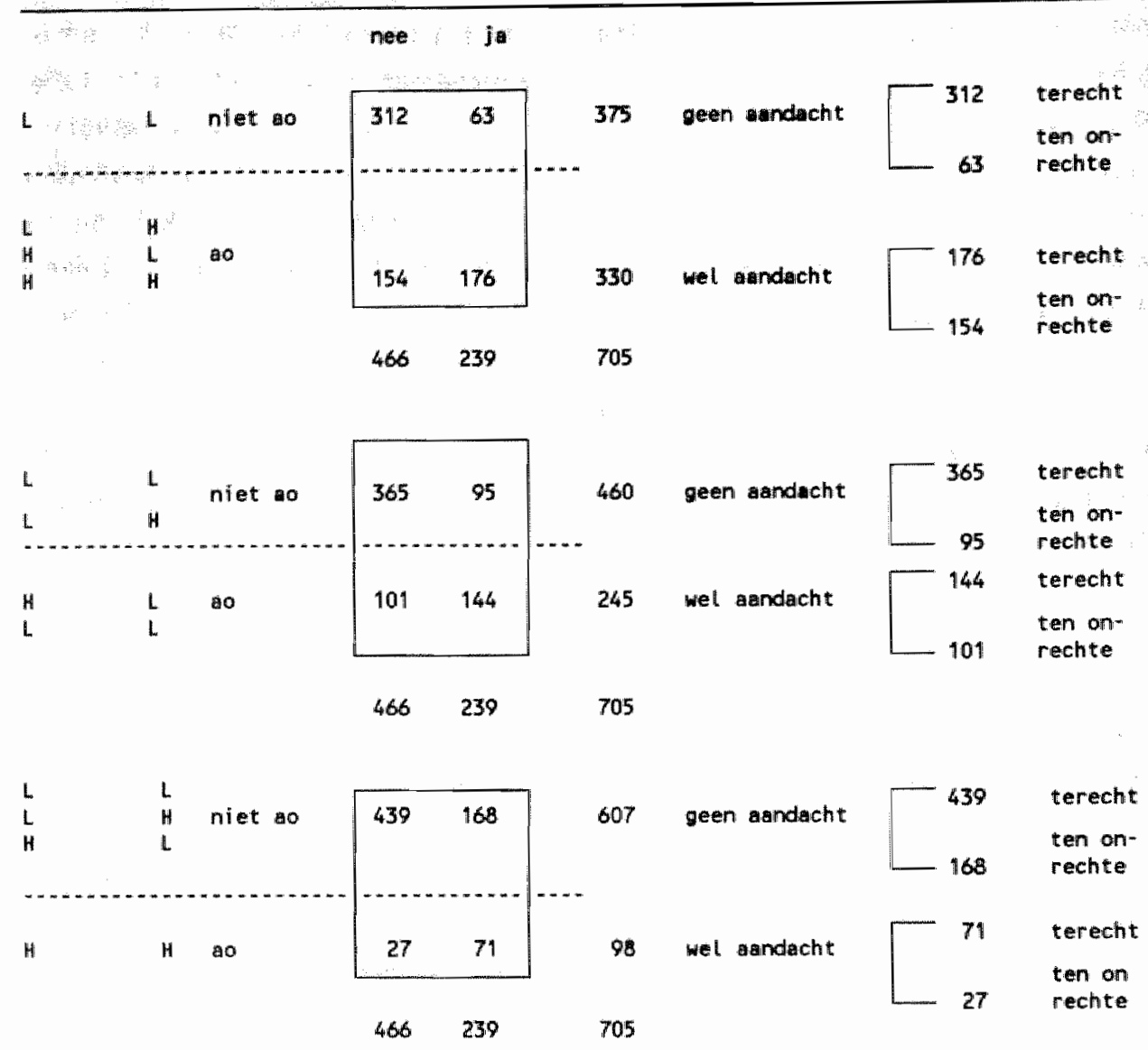

niet-ao = niet arbeidsongeschikt, ao = arbeidsongeschikt

In de praktijk kan men kiezen hoe zwaar men de ene of de andere fout rekent. Afhankelijk van de voor-en nadelen van deze keuze en van de beschikbare middelen, moet men in een praktijksituatie zelf bepalen, waar men de grens bij een voorspelling trekt. Gegeven de doelstelling en de praktische mogelijkheden, zal een bedrijfsgeneeskundige dienst de ligging van de grenswaarden zelf moeten 
kiezen, rekening houdend met alle consequenties. Het antrekkelijke van lage grenzen is, dat vrijwel alle toekomstige arbeidsongeschikten de zorg zouden kunnen krijgen die ze nodig hebben. Het nadeel van te lage grenswaarden is daarbij echter dat de werklast voor de BGD groot wordt. Dit zou zelfs ten koste van andere taken van de BGD kunnen gaan. Een te lage grens bij de voorspelling zou dus vastlopen op de beperkte capaciteit van de BGD.

Een hoge grens dus? Dan treden er geen problemen met de werkdruk binnen de BGD op, maar worden er meer toekomstige arbeidsongeschikten over het hoofd gezien. Werknemers in moeilijkheden worden dan misschien niet meer herkend en ze kunnen in hun werk met vallen en opstaan doorgaan, tot de schijnbaar onvermijdelijke arbeidsongeschiktheid. Hierbij komt niet de BGD, maar de werknemer in de problemen. Bovendien zijn de matschappelijke kosten hoog, want een arbeidsongeschikte werknemer kost tot aan zijn 65 ste jaar tot $70 \%$ wan zijn laatstverdiende inkomen (zie paragraaf 2.2.1). Net als eerder werd gesteld: er moet getaxeerd worden, hoeveel werknemers er hulp kunnen krijgen gezien de mogelijkheden van de BGD in het concrete bedrijf afgezet tegen de kans dat werknemers problemen hebben en toch niet geholpen worden. Dit is geen technische keuze, daarom kan er hier geen pasklare oplossing worden aangeboden: de kosten en baten moeten in een concrete situatie geschat en afgewogen worden.

\section{Validiteit yan de lange VAG}

Zoals eerder bleek (paragraaf 4.1.1) zijn de verschillen op de totaalscore van de lange VAG tussen wel- en niet-arbeidsongeschikten veel geringer dan de verschillen op onderdelen van de VAG, namelijk de somscores Gezondheid, Inspanning en Ziektegedrag (tezamen de index Conditie ${ }_{1}$ ). De VAG bleek dus een samenstel van voor de voorspelling van arbeidsongeschiktheid relevante en irrelevante informatie, en is daardoor als geheel een minder valide voorspeller dan Conditie, alleen.

Dit neemt niet weg dat met het relevante deel van de lange VAG, dus de index Conditie $_{l}$, praktische voorspellingen van arbeidsongeschiktheid te bereiken zijn, met (afgezien van de groep 35 - 49 jaar, waarin weinig arbeidsongeschiktheid voorkomt) incidentiedichtheidsratio's (IDR's) van gemiddeld 7.9 tot ongeveer 20 toe (tabel 4.3). Nemen we als criterium de waarde wan 4.6 (Appels, zie eerder in 
deze paragraaf), dan komen al deze IDR's daarboven en we mogen daarom vast-

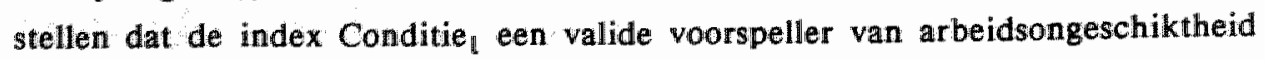
is. Bij de vraagstelling (paragraaf 1.2.2) bleek al dat de mogelijkheid om te voorspellen en de predicitieve validiteit van de VAG elkaars spiegelbeeld zijn; is de voorspelling sterk, dan is de predictieve validiteit hoog en omgekeerd. Nu blijkt dat arbeidsongeschiktheid goed op basis van een deel van de lange VAG te voorspellen is, is de conclusie dat dat deel ook een goede prediciteve validiteit heeft. Ernstige wanwerhoudingen tussen de belasting en de belastbaarheid van werknemers, die zelfs tot arbeidsongeschiktheid kunnen leiden, kunnen er in bedrijfsgezondheidskundig onderzoek op valide wijze mee worden opgespoord.

\subsection{Voorspelling wan verwroegd uittreden}

De vervroegd uitgetreden werknemers worden (zie paragraaf 3.9.1) vergeleken met de werknemers die in het jaar van het bedrijfsonderzoek 58 jaar of ouder waren. Er zijn verzuimeijfers van 104 mannelijke werknemers in de VUT-groep en van 318 in de vergelijkingsgroep; de aantallen bij de enquêtegegevens zijn respectievelijk 84 en 242 . Vrouwelijke werknemers in de VUT komen binnen het materiaal niet voor.

\subsubsection{Verschillen tussen wel- en niet-VUT}

De gemiddelden op de dertien verklarende variabelen van de mannelijke werknemers die niet resp. wel vervroegd uittraden, worden gegeven in tabel 4.7.

Van alle wariabelen geeft slechts het verzuimpercentage in alle vergeleken groepen een significant verschil te zien. Telkens heeft de VUT-groep een aanmerkelijk lager verzuimpercentage dan de vergelijkingsgroep van 58 jaar en ouder. 


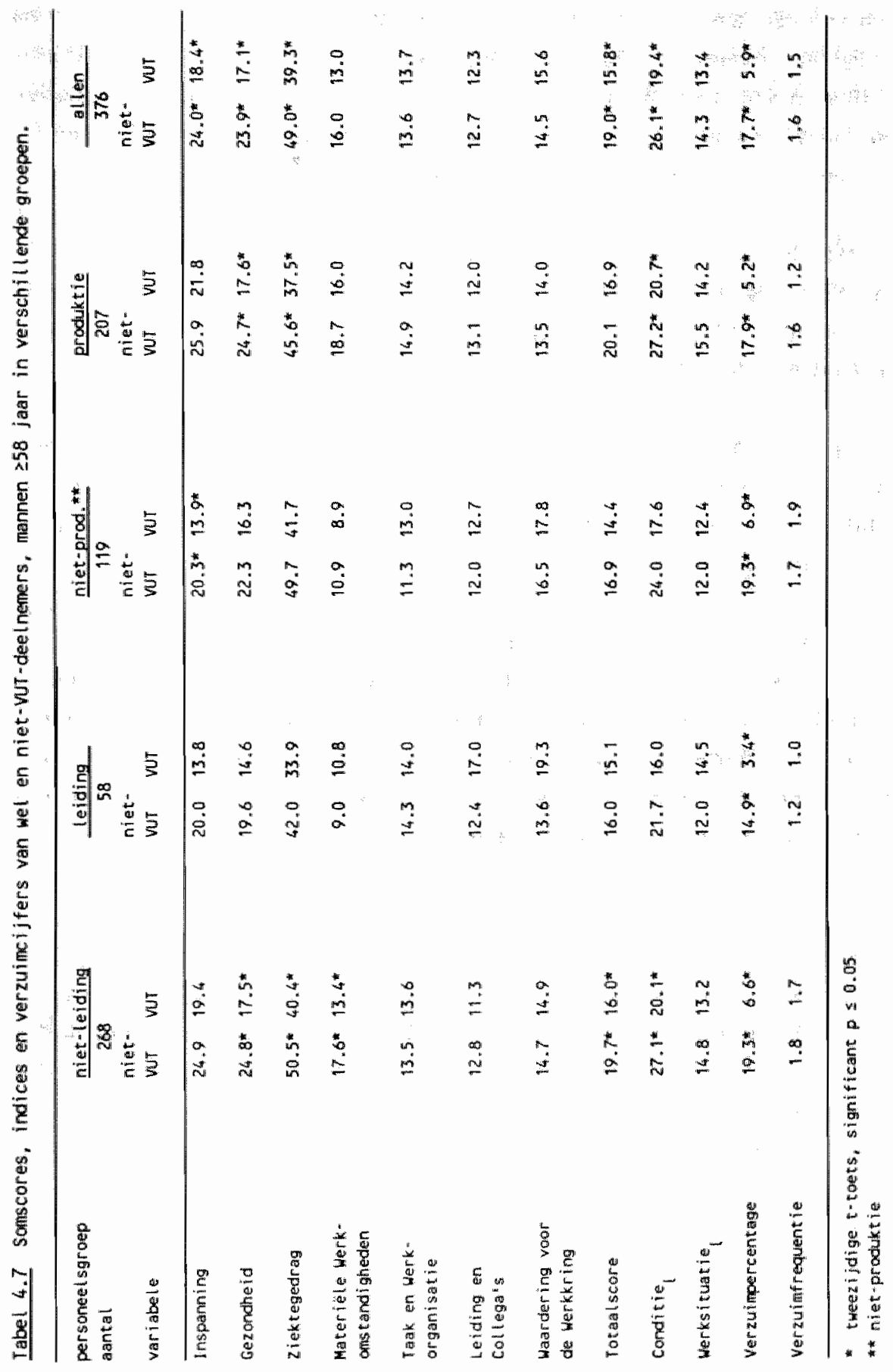


Afgezien van een aantal variabelen die nergens behoorlijke verschillen opleveren en die blijkbaar irrelevant voor verwroegd uittreden zijn (Taak en Werkorganisatie, Leiding en Collega's, Waardering voor de Werkkring, de index Werksituatie en de verzuimfrequentie) zijn er een aantal variabelen die slechts in enkele groepen werknemers een aanmerkelijk verschil opleveren.

Dit betreft de somscores Inspanning, Gezondheid, Ziektegedrag, Materiële

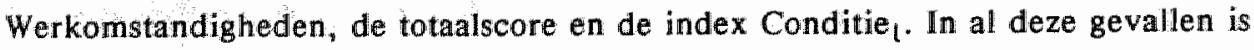
de score van de VUT-groep lager dan die van de vergelijkingsgroep, hetgeen overeenstemt met de richting van het verschil in het verzuimpercentage.

Over groepen werknemers beschouwd valt op dat er twee groepen indelingen zijn, nl. eèn die betrekkelijk veel verschillen tussen wel- en niet-VUT hebben, nl. produktie, niet-leiding en alle werknemers en één met weinig verschillen, nl. leidinggevenden en niet-produktie.

Net als eerder bij het onderwerp "arbeidsongeschiktheid" zijn er dus maar enkele variabelen die mogelijk goede voorspellers van vervroegd uittreden zijn, namelijk Inspanning, Gezondheid en Ziektegedrag, Conditie, en het verzuimpercentage. Om de bewerkingen uniform te houder is hieraan de verzuimfrequentie toegevoegd en over deze groep variabelen is, in paragraaf 4.2 .3 de voorspellende kracht (incidentiedichtheidsratio"s) berekend.

\subsubsection{Variabelen in de tijd voor het vervroegd uittreden}

Hetzelf de probleem doet zich voor als bij de arbeidsongeschiktheid, namelijk dat de achtereenvolgende jaarklassen elk uit volkomen werschillende groepen werknemers bestaan. De aantallen werknemers lopen hier van 12 tot 37 per jaar bij de enquêtegegevens en van nul tot 43 bij de verzuimgegevens. Doordat weinig gegevens ter beschikking zijn, kan de gezochte informatie (stijging of daling van de variabelen in de tijd voor de VUT) bij de beschikbare aantallen werknemers niet onderscheiden worden temidden van de verdere variatie. 
De aantallen zijn te laag om schattingen te kunnen maken die algemeen zouden moeten gelden. De betreffende gegevens (ter inzage bij de auteur) worden om deze reden hier niet vermeld.

\subsubsection{Vervroegd uittreden; voorspellend vermogen per variabele}

De hier toegepaste incidentiedichtheidsratio's (IDR's) zijn kansverhoudingen, gedefinieerd in paragraaf 3.11 en de presentatie met grenswaarden die telkens $10 \%$ opschuiven. De IDR"s bij deze grenswaarden op de in paragraaf 4.2 .1 gekozen variabelen voor de VUT zijn aangegeven in tabel 4.8 .

De meeste IDR's zijn kleiner dan één, hetgeen betekent dat werknemers met een hoge score of een hoog verzuim minder kans op latere toetreding tot de VUT hebben dan werknemers met een lage score. Anders gesteld: niet een hoge, maar een lage score is indicatief voor later toetreden tot de VUT. Degenen die later met de VUT zouden gaan hebben overwegend lage scores (weinig geuite problemen) en een laag verzuim, het laatste zowel in percentage als in frequentie.

Veel IDR's bereiken waarden van .35 tot .50 , waarbij eigenlijk alleen de verzuimfrequentie niet vaak tot deze lage waarden komt. Beschouwing van de groepen werknemers (kolommen) leert, dat de IDR's in de groepen totaal, nietleiding en produktie geprononceerder zijn dan in de groepen leiding en nietproduktie. De toekomstige vervroegd uittreders in deze groepen werknemers zijn relatief gezonde werknemers met weinig klachten en een laag verzuim. Wat de waarde van deze IDR's als voorspellers van VUT-toetreden is, kan nader worden bepaald aan de hand van de sensitiviteit en de specificiteit. 
rabet 4.8 Incldentiedichthefidsrat to:s wan zes wartabelen bil de WT (mannelijke werkne* mers)

\begin{tabular}{|c|c|c|c|c|c|c|}
\hline $\begin{array}{l}\text { groep } \\
\text { antal }\end{array}$ & grens & $\begin{array}{l}\text { leiding } \\
58\end{array}$ & $\begin{array}{l}\text { nifet- } \\
\text { leiding } \\
268\end{array}$ & $\begin{array}{l}\text { produktie } \\
207\end{array}$ & $\begin{array}{l}\text { niet- } \\
\text { produktie } \\
419\end{array}$ & $\begin{array}{l}\text { allen } \\
584 \\
326\end{array}$ \\
\hline $\begin{array}{l}\text { Inspan- } \\
\text { ning }\end{array}$ & $\begin{array}{l}28 / 72 \\
46 / 54 \\
60 / 40 \\
80 / 20 \\
86 / 14\end{array}$ & $\begin{array}{l}0.34 \\
0.35 \\
0.36 \\
0.69 \\
0.92\end{array}$ & $\begin{array}{l}0.52 \\
0.53 \\
0.61 \\
0.61 \\
0.39\end{array}$ & $\begin{array}{l}0.32 \\
0.38 \\
0.64 \\
0.91 \\
0.52\end{array}$ & $\begin{array}{l}0.89 \\
0.74 \\
0.52 \\
0.32 \\
0.38\end{array}$ & $\begin{array}{l}0.48 \\
0.49 \\
0.56 \\
0.62 \\
0.44\end{array}$ \\
\hline $\begin{array}{l}\text { Gezond- } \\
\text { ineid }\end{array}$ & $\begin{array}{l}20 / 80 \\
32 / 68 \\
41 / 59 \\
50 / 50 \\
57 / 43 \\
70 / 30 \\
80 / 20 \\
90 / 10\end{array}$ & $\begin{array}{l}0.60 \\
0.33 \\
0.33 \\
0.32 \\
0.28 \\
0.41 \\
0.64 \\
1.13\end{array}$ & $\begin{array}{l}0.52 \\
0.39 \\
0.39 \\
0.47 \\
0.54 \\
0.56 \\
0.53 \\
0.23\end{array}$ & $\begin{array}{l}0.41 \\
0.34 \\
0.33 \\
0.46 \\
0.55 \\
0.58 \\
0.53 \\
0.39\end{array}$ & $\begin{array}{l}0.85 \\
0.47 \\
0.48 \\
0.46 \\
0.45 \\
0.49 \\
0.60 \\
0.29\end{array}$ & $\begin{array}{l}0.56 \\
0.39 \\
0.38 \\
0.45 \\
0.49 \\
0.53 \\
0.54 \\
0.34\end{array}$ \\
\hline $\begin{array}{l}\text { Zliekteo } \\
\text { gedrag }\end{array}$ & $\begin{array}{l}32 / 68 \\
56 / 46 \\
77 / 23 \\
93 / 07\end{array}$ & $\begin{array}{l}0.89 \\
0.50 \\
0.76 \\
0.86\end{array}$ & $\begin{array}{l}0.65 \\
0.49 \\
0.38 \\
0.38\end{array}$ & $\begin{array}{l}0.73 \\
0.33 \\
0.28 \\
0.33\end{array}$ & $\begin{array}{l}0.65 \\
0.85 \\
0.64 \\
0.32\end{array}$ & $\begin{array}{l}0.69 \\
0.50 \\
0.43 \\
0.35\end{array}$ \\
\hline $\begin{array}{l}\text { Condi- } \\
\text { tiet }\end{array}$ & $\begin{array}{l}08 / 92 \\
16 / 84 \\
30 / 70 \\
36 / 64 \\
47 / 53 \\
57 / 43 \\
74 / 26 \\
80 / 20 \\
90 / 10\end{array}$ & $\begin{array}{l}0.31 \\
0.42 \\
0.41 \\
0.35 \\
0.34 \\
0.41 \\
0.41 \\
0.61 \\
1.13\end{array}$ & $\begin{array}{l}0.52 \\
0.53 \\
0.42 \\
0.48 \\
0.42 \\
0.55 \\
0.40 \\
0.43 \\
0.25\end{array}$ & $\begin{array}{l}0.27 \\
0.33 \\
0.34 \\
0.35 \\
0.38 \\
0.48 \\
0.47 \\
0.52 \\
0.37\end{array}$ & $\begin{array}{l}0.83 \\
0.99 \\
0.60 \\
0.69 \\
0.49 \\
0.66 \\
0.34 \\
0.39 \\
0.31\end{array}$ & $\begin{array}{l}0.43 \\
0.50 \\
0.42 \\
0.46 \\
0.41 \\
0.53 \\
0.40 \\
0.46 \\
0.34\end{array}$ \\
\hline vw & $\begin{array}{l}20 / 80 \\
30 / 70 \\
40 / 60 \\
50 / 50 \\
60 / 40 \\
70 / 30 \\
80 / 20 \\
90 / 10\end{array}$ & $\begin{array}{l}1.40 \\
0.78 \\
0.99 \\
1.06 \\
0.55 \\
0.33 \\
0.41 \\
0.48\end{array}$ & $\begin{array}{l}0.70 \\
0.64 \\
0.63 \\
0.46 \\
0.43 \\
0.36 \\
0.39 \\
0.14\end{array}$ & $\begin{array}{l}0.68 \\
0.54 \\
0.64 \\
0.38 \\
0.32 \\
0.28 \\
0.28 \\
0.07\end{array}$ & $\begin{array}{r}1.03 \\
.96 \\
.81 \\
.85 \\
.72 \\
.60 \\
.66 \\
.28\end{array}$ & $\begin{array}{l}0.80 \\
0.67 \\
0.69 \\
0.53 \\
0.45 \\
0.37 \\
0.40 \\
0.13\end{array}$ \\
\hline VF & $\begin{array}{l}21 / 79 \\
45 / 55 \\
65 / 35 \\
79 / 21 \\
88 / 12\end{array}$ & $\begin{array}{l}11.40 \\
0.81 \\
0.60 \\
0.60 \\
0.83\end{array}$ & $\begin{array}{l}0.70 \\
0.68 \\
0.84 \\
0.84 \\
0.96\end{array}$ & $\begin{array}{l}0.68 \\
0.49 \\
0.41 \\
0.41 \\
0.59\end{array}$ & $\begin{array}{l}1.03 \\
1.04 \\
1.75 \\
1.75 \\
2.29\end{array}$ & $\begin{array}{l}0.80 \\
0.70 \\
0.82 \\
0.82 \\
0.94\end{array}$ \\
\hline
\end{tabular}




\section{Sensitiviteit en specificiteit}

De sensitiviteit en specificiteit (zie paragraaf 3.11) zijn afhankelijk van de grens die in de voorspellende variabele getrokken wordt (bijlage 5). Net als eerder bij de arbeidsongeschiktheid (paragraaf 4.1.3) neemt de sensitiviteit bij voorspelling van de VUT af en neemt de specificiteit toe naarmate de grenswaarde in de variabele hoger komt te liggen (zie bijlage 7). Evenals bij arbeidsongeschiktheid kiezen we als voorbeeld de index Conditie, over alle werknemers (d.w.z. hier 58 jaar en ouder); figuur 4.3 geeft de betreffende grafiek.

figur 4.3 Sensitiviteit en specificiteit van de index conditiel bij voorspelling van vervroegd uittreden, mannen 58 jaar en ouder $(n=362$ )

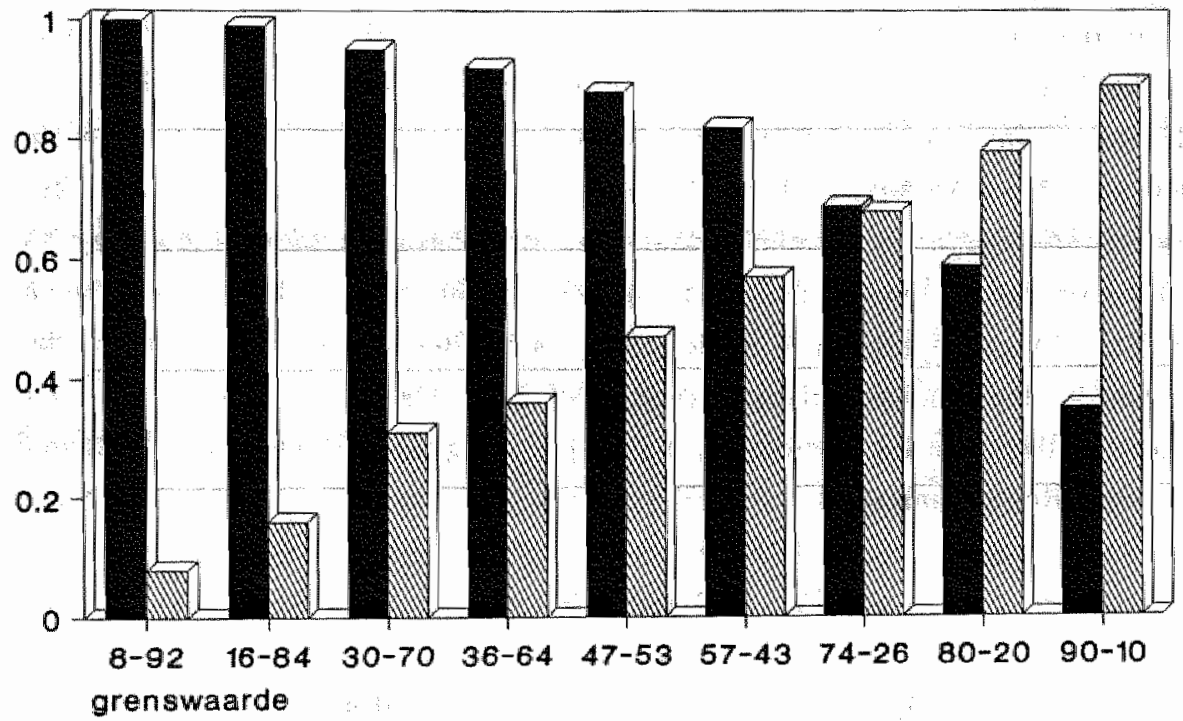

Sensitiviteit Specificiteit

Er zijn echter ook verschillen ten opzichte van de arbeidsongeschiktheid, want de sensitiviteit neemt hier sneller af dan bij de arbeidsongeschiktheid. Bijvoor-

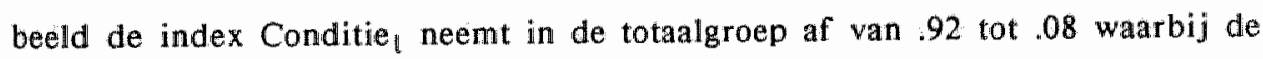
sensitiviteit toeneemt van .04 tot .81 . Duidelijker dan bij arbeidsongeschiktheid is hier dat er nergens een compromis gevonden kan worden waarbij de beide grootheden tegelijk aanvaardbaar zijn.

Dit is grond yoor twee conclusies wat betreft de voorspelbaarheid van vervroegd 
uittreden. Ten eerste lijken de IDR's van tabel 4.8 misschien bruikbaarder dan ze zijn. Gezien het woorgaande is geen sterke individuele voorspelling mogelijk. Ten tweede is er weinig kans om door enquêtegegevens en verzuimgegevens te combineren tot een betere individuele voorspelling te komen. Groepsgewijze voorspellingen van de VUT zijn echter uitstekend te doen.

4.2.4 Vervroegd uittreden: voorspelling uit werknemersmeningen en verzuimgegevens

\section{Logistische regressie-analyse}

Net als in paragraaf 4.1.4 waar de vraag beantwoord werd, hoe goed arbeidsongeschiktheid met meer variabelen tegelijk individueel te voorspellen is, komt hier de vraag aan de orde, of ${ }^{3}$ de VUT met twee variabelen beter te voorspellen valt dan met eên. Als voorspellers zijn gekozen de index Conditie, en het verzuimpercentage, omdat deze (tabel 4.4) ook bij de arbeidsongeschiktheid gekozen werden en omdat ze net als de meeste andere variabelen goede voorspellingen van de VUT mogelijk bleken te maken. Zie voor uitleg van de techniek die gebruikt wordt, logistische regressie, paragraaf 3.11. De vergelijking hieronder geeft het resultaat van de bewerking, waarbij $y=\log$ odds VUT, $x_{1}=$ Conditie $_{\iota}$ en $x_{2}=$ verzuimpercentage:

$$
y=0.73-0.52 x_{1}-0.97 x_{2}
$$

De chi kwadraat is 0.19 ; niet significant, zodat het model goed aan de gegevens is aangepast. Verder zijn de coèfficiënten van $x_{1}$ en $x_{2}$ negatief, wat er op wijst dat de VUT samengat met een lagere score op Conditie, en een lager verzuimpercentage. Dit stemt overeen met wat er in de vorige paragraaf gevonden werd en met het resultaat, dat arbeidsongeschiktheid en VUT elkaars spiegelbeeld zijn, in die zin, dat de eerstgenoemde door ongezondheid en de tweede door relatieve gezondheid bepald wordt.

De vraag, wat de kans op VUT is bij de twee gecombineerde variabelen, is nog niet beantwoord; tabel 4.9 geeft de cijfers. 
Iabel 4.9 Waargenomen en voorspelde odds van de VuT, sensitiviteit en specificiteit van tegelijk Conditiel en Verzulimpercentage. mannelijke werknemers 58* jaar $(n=325)$

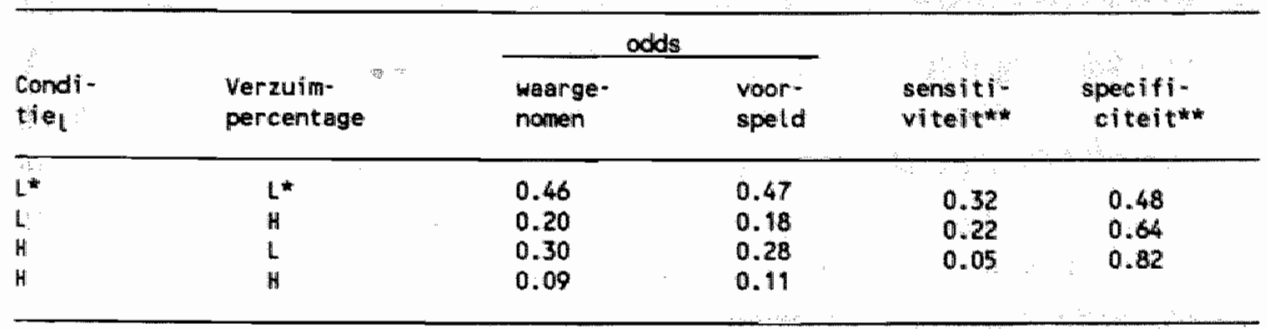

$L=$ laag, onderste $80 \%, H=$ hoog, bovenste $20 \%$ zie bijlage 5 voor de ligging van de grenzen.

** Bij respectievelijk LL tegenover de rest, $L L$ en $L H$ tegenover de rest en $L L$, $L H$, $H H$ tegenover $\mathrm{HH}$

Het is duidelijk dat bij kans op VUT (de odds) in de volgorde $L L t / m$ HH af neemt. Werknemers met een laag verzuimpercentage en lage Conditie, (dus met een goede gezondheid), hebben een wijf maal zo grote kans $(0.46 / 0.09)$ om later in de VUT te gaan als werknemers bij wie beide gegeven hoog zijn (dus een minder goede gezondheid).

\section{Sensitiviteit en specificiteit}

Hoe valide is nu de voorspelling van de VUT uit Conditie, en verzuimpercentage? Voor tabel 4.9 zijn de sensitiviteit en specificiteit (zie paragraaf 3.11) uitgerekend, bij een grens van $80 \%$ laag $-20 \%$ hoog.

Eerder werd geconcludeerd, dat de afzonderlijke gegevens Conditie, en verzuimpercentage geen goede voorspellers van verwroegd uittreden zijn. Gezien de waarden in tabel 4.9 van sensitiviteit en specificiteit moet die conclusie gehandhaafd worden. Ook met twee variabelen is VUT niet goed te voorspellen; het materiaal bevat geen krachtige individuele woorspellers van de VUT.

\subsubsection{Vervroegd uittreden en lange VAG: discussie}

Evenals bij het onderwerp 'arbeidsongeschiktheid' worden hieronder drie kanten van de uitkomsten behandeld, namelijk de overeenstemming tussen deze uitkom- 
sten en de literatuur, de voorspelbaarheid van het vervroegd uitureden en de validiteit van de $\mathrm{VAG}$ in het licht van de uitkomsten.

\section{Overeenstemming met de literatuur}

Verschillendle bronnen noemen een ongunstige verhouding tussen belasting en belastbaarheid als kenmerk van VUT-gangers. De VUT zou dus een toevlucht zijn voor vermoeide of versleten werknemers. De resultaten van het onderzoek spreken dit laatste in verschillende toonaarden tegen. De VUT-groep heeft minder klachten over inspanning, gezondheid en ziektegedrag dan de niet-VUTgroep en bovendien is het verzuimpercentage van de VUT-groep betrekkelijk laag. Alles wijst er op, dat de VUT-groep hier een relatief gezonde, niet overbelaste groep werknemers is. De groep VUT-gangers vormt hier in termen van gezondheid het tegendeel van de groep arbeidsongeschikten. Dit pleit ook tegen de concurrentiehypothese uit de literatutr, die stelt dat VUT en arbeidsongeschiktheid allebei regelingen zijn, die een uitweg bieden aan werknemers met problemen. De resultaten laten eerder zien dat de groep arbeidsongeschikten en de VUT-groep elkaars spiegelbeeld zijn in termen van klachten (over werk en gezondheid) en ziekteverzuim.

De vraag ligt voor de hand of het materiaal wel representatief is. In paragraaf 3.9.4 bleek, dat leidinggevenden vaker vervroegd uittreden dan niet-leidinggevenden en dat in niet-produktieafdelingen meer van de VUT gebruik wordt gemaakt dan in produktieafdelingen. In de resultaten zou kunnen meespelen, dat de niet-leidinggevenden en de produktieafdelingen ondervertegenwoordigd zijn in de gegevens. Dit lijkt in overeenstemming met de percentages van tabel 3.24 en 3.25. Kijken we echter naar de absolute aantallen, dan zijn die bij de produktieafdelingen hoger dan bij de niet-produktie en bij de niet-leidinggevenden hoger dan bij de leidinggevenden. Dat het gevonden verschil tussen literatuur en onze uitkomsten een artefact zou zijn van een scheve verhouding tussen de respectievelijke aantallen werknemers, is daarom niet erg aannemelijk.

Een andere mogelijkheid is, dat de VUT-groep die met 62 jaar vertrok, jonger was dan de vergelijkingsgroep. Uit figuur 3.3 en 3.6 bleek, dat de index Conditie, en zijn onderdelen net als het verzuimpercentage toeneem met stijgende leeftijd. Hierdoor zou misschien de vergelijkingsgroep hoger op deze variabelen 
gescoord kunnen hebben. Tabel 3.23 leert echter dat de gemiddelde leeftijd in de VUT-groep 62.4 jaar is, terwijl die in de vergelijkingsgroep $58+(65-58)=$ 61.5 jaar moet zijn, (afgezien van uitval door arbeidsongeschiktheid on overlijden). Een verklaring op grond van verschil in leeftijd is daarom onhoudbaar, net als de eerdere op grond van onevenredig opgebouwde groepen.

De oorspronkelijke uitkomst, dat de VUT-groep betrekkelijk weinig problemen heeft, kan gezien het voorgaande gehandhaafd worden. Over de achtergrond hiervan kunnen we, bij gebrek aan verdere gegevens, alleen speculeren. Het is mogelijk, dat de werknemers die de VUT-leeftijd naderen liever niet in de (financieel minder gunstige) arbeidsongeschiktheidsregelingen komen en dat zij daarom hun problemen dissimuleren teneinde de VUT niet mis te lopen. Misschien is dit een vergezochte verklaring; toch kan niet uitgesloten worden dat zulke werknemers ziek doorwerken; dit zou hun relatief lage verzuimpercentage kunnen verklaren. Dit lage percentage is zo wel aannemelijk te maken, maar dat geldt niet voor de lage VAG-scores en -indices uit de werknemersenquête. Die laatste was vertrouwelijk (de individuele gegevens gingen niet naar het bedrijf), en de resultaten waren niet individu-mar groepsgericht. De enquête had dus geen invloed op de individuele werksituatie, daarom is de verklaring van de gevonden verschillen op grond van een dissimulatie-verklaring niet aannemelijk.

Een derde mogelijkheid is, dat het verwachte inkomen bij de VUT-groep hoger was dan bij de vergelijkingsgroep (zie paragraaf 2.3.4). De laatstgenoemde groep zou als gevolg daarvan misschien een somberder kijk op werk en gezondheid gekregen hebben en daardoor meer zijn gaan verzuimen dan de VUT-groep. Dit alles ligt weinig voor de hand; overigens kan deze onderstelling hier niet getoetst worden, aangezien er geen gegevens voorhanden zijn over het verwachte of het werkelijke latere inkomen. Deze verklaring kan dus beter blijwen rusten.

Een laatste verklaring kan worden ontleend aan Philipsen \& Halfens (1983). Vervroegd uittreden zou men op een andere wijze bereiken dan arbeidsongeschiktheid (of werkloosheid), doordat er al veel langere tijd gezondheidsverschillen bestaan. Er zou al jarenlang een latent gezondheidsprobleem kunnen zijn bij de toekomstige arbeidsongeschikten, terwijl cen dergelijk probleem bij de toekomstige VUT-groep zou ontbreken. De gegevens zijn ook hierbij niet toereikend om vast te stellen of dit een juiste veronderstelling is. We kunnen alleen 
vaststellen dat de toetreders tot de VUT weinig problemen en weinig verzuim hebben, anders dan de literatuur deed verwachten.

\section{Voorspelbaarheid wan toetreding tot de VUT}

Al dan niet toetreden tot de VUT is geen lot dat iemand overkomt, maar een beslissing die hil zelf neemt, onder enkele voorwaarden (nl. dat hij voldoende lang in een bedrijf of bedrijfstak gewerkt heeft, dat hij de VUT-leeftijd bereikt, en logischerwijs verder dat hij niet eerder op andere wijze vertrekt). Om die reden is het niet helemaal juist om van een 'kans op verwroegd uittreden' te spreken.

Een toelichting. Verzekeraars gaan uit van een kansverdeling als basis voor het afsluiten van een bepaalde verzekering. Gaat de verzekerde zich anders gedragen door het verzekerd-worden en beïnvloedt hij zodoende de kanswerdeling, dan is er sprake van 'moral hazard', een vervalsing van de aanvankelijke kansen door keuzen van de verzekerde (zie bijv. Nordquist \& Wu, 1976). De VUT zet de deur hier wagenwijd voor open, reden waarom het geforceerd klinkt, te spreken van 'kans op', en zeker 'risico van' VUT. Toch waagden we een poging tot voorspelling van later toetreden tot de VUT.

In eerste aanleg (tabel 4.7) bleek een aantal variabelen verschillen tussen wel- en niet-VUT-groep te vertonen. Het betreft hier Inspanning, Gezondheid, Ziektegedrag, Conditie, en verzuimpercentage, met dien verstande dat de VUT-groep hierbij minder klachten heeft dan de vergelijkingsgroep. Deze groep variabelen is daarom, voor de vergelijkbaarheid met de andere vertrekwijzen, uitgebreid met de verzuimfrequentie en vervolgens zijn om de voorspellende kracht vast te stellen, de incidentiedichtheidsratio's (IDR's) berekend.

De IDR's lopen ongeveer van 0.35 tot 0.50 . Dat zij kleiner dan één zijn, wil zeggen dat bij een lage score iemand meer kans heeft op latere toetreding dan bij een hogere score. De individuele voorspelling is echter niet nauwkeurig (lage sensitiviteit en specificiteit). Verbetert dit laatste bij het gebruik van twee voorspellers (Conditie, en verzuimpercentage)? De incidentiedichtheidsratio's van deze twee afzonderlijke voorspellers in tabel 4.8 geven aan dat de kans op VUT bij een lage score op éen van deze variabelen meestal ongeveer $1 / 0.50$ is, dus 
ongeveer twee. Het combineren van twee voorspellers (tabel 4.9) leidt meestal tot een hogere kans. De nauwkeurigheid van ook deze voorspelling (sensitiviteit en specificiteit, zie bijlage 7) is echter laag. Zoals eerder werd vastgesteld, bevat het materiaal geen krachtige individuele voorspellers van de VUT. Ligt dat aan de beschikbare gegevens? Uit de literatuur werd onder meer geconcludeerd dat de VUT-beslissing mede afhangt van het verwacht inkomen na uittreden. Onze uitkomsten wijzen ook in deze richting; wil men een sterke individuele voorspelling van de VUT, dan zal men mede over gegevens met betrekking tot het verwachte individuele inkomen moeten beschikken. Dit vereist dus sterk gespecialiseerde gegevens, die bij een algemeen bedrijfsonderzoek (waar de hier beschikbare gegevens immers ook op gebaseerd zijn), niet verzameld worden.

Toetreden tot de VUT bleek samen te gaan met weinig problemen met de gezondheid. Dit zou een reden kunnen zijn om de VAG, die naar problemen peilt, zo te ontwikkelen dat ook de positieve kanten van gezondheid, werk en werkomstandigheden in beeld worden gebracht. Dat zou op twee manieren kunnen, nl. a) vragen toevoegen over positieve aspecten van arbeid en gezondheid en b) antwoordmogelijkheden aanbieden die zowel de negatieve als de positieve kant omvatten.

\section{Validiteit van de VAG}

Vanwege de geringe aantallen werknemers in de afzonderlijke kategorieën werknemers worden de uitkomsten wat betreft de VAG hier beperkt tot de totale VUT-groep. De totalscore, de index Conditie, en de somscores die daar deel van vitmaken (Inspanning, Gezondheid en Ziektegedrag) zijn in de VUT-groep lager dan in de vergelijkingsgroep. De resterende somscores geven maar in enkele gevallen aanmerkelijke verschillen te zien. De verzuimfrequentie toont verschillen in dezelfde richting als bewijs dat de verschillen in de scores wel een reèle basis hebben in het gedrag van de werknemers, dus als bewijs woor de validiteit van deze verschillen.

De voorspellingen met de betreffende variabelen blijken, hoewel de verschillen niet erg groot zijn, behoorlijke waarden te bereiken (IDR's typisch 0.35 tot 0.50 ; of hun reciproken 2.00 tot 2.85 ). Ze zijn echter niet erg nauwkeurig (lage sensitiviteit en specificiteit). Dit laatste is praktisch gezien teleurstellend, maar het is 
geen bewijs tegen de validiteit van de VAG. Zoals we zagen is een zekere voorspelling van de VUT mogelijk en lopen lage VAG-scores samen met lage verzuimeijfers. Dit geeft respectievelijk steun aan de predictieve- en de constructvaliditeit van de lange VAG. Er zijn dus ook uit de resultaten m.b.t. de VUT argumenten te putten voor de validiteit van de VAG.

\subsection{Voorspelling van ontslagname}

4.3.1 Verschillen tussen wel- en niet-ontslagname, lange VAG

Een overzicht van de gemiddelden van de verklarende variabelen in de verschillende groepen die bij ontslagname onderscheiden zijn (zie paragrafen 3.5 en 3.6) wordt geboden in tabel 4:10.

In twee groeperingen, namelijk de vrouwelijke werknemers van 16 tot 34 jaar en de mannelijke leidinggevenden, komen bij geen enkele variabele significante verschillen voor. Er is omgekeerd geen enkele variabele die in alle groepen werknemers verschil maakt tussen de wel en niet met vrijwillig ontslag vertrokkenen. We zullen ons daarom tot een keuze van voorbeeldgroepen en -variabelen moeten beperken

De totaalscore levert in vier groepen een significant verschil. Variabelen die in de helft of meer van de twaalf groeperingen van tabell 4.10 een significant verschil maken zijn de somscores Taak en Werkorganisatie (in zeven groepen) Waardering voor de Werkkring (negen groepen) en de verzuimfrequentie (zes groepen). Ontslagname heeft blijkbaar meer te maken met de werkinhoud, de werkomstandigheden en de verzuimfrequentie dan met de inspanning, de gezondheid en het verzuimpercentage. 


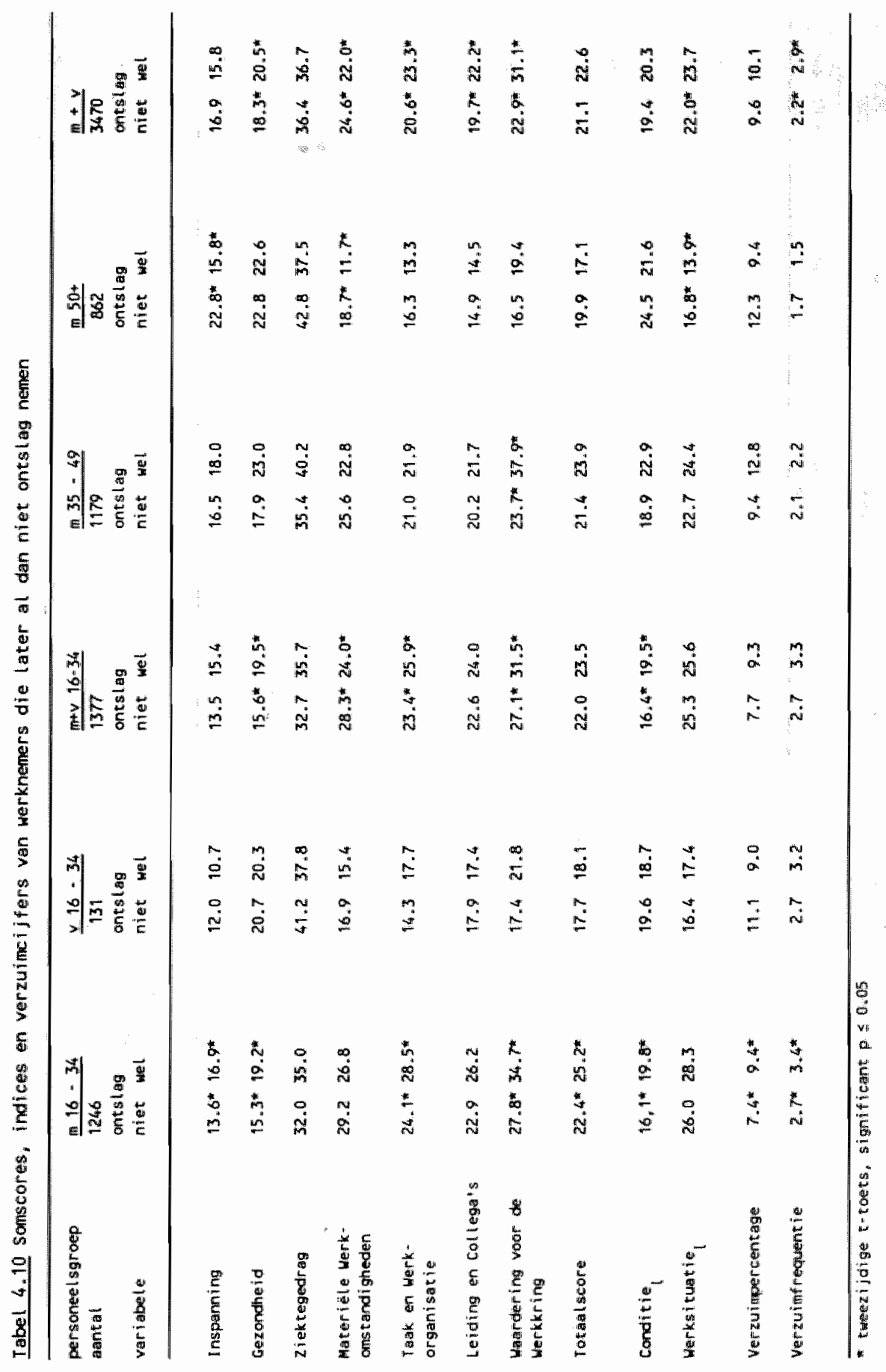




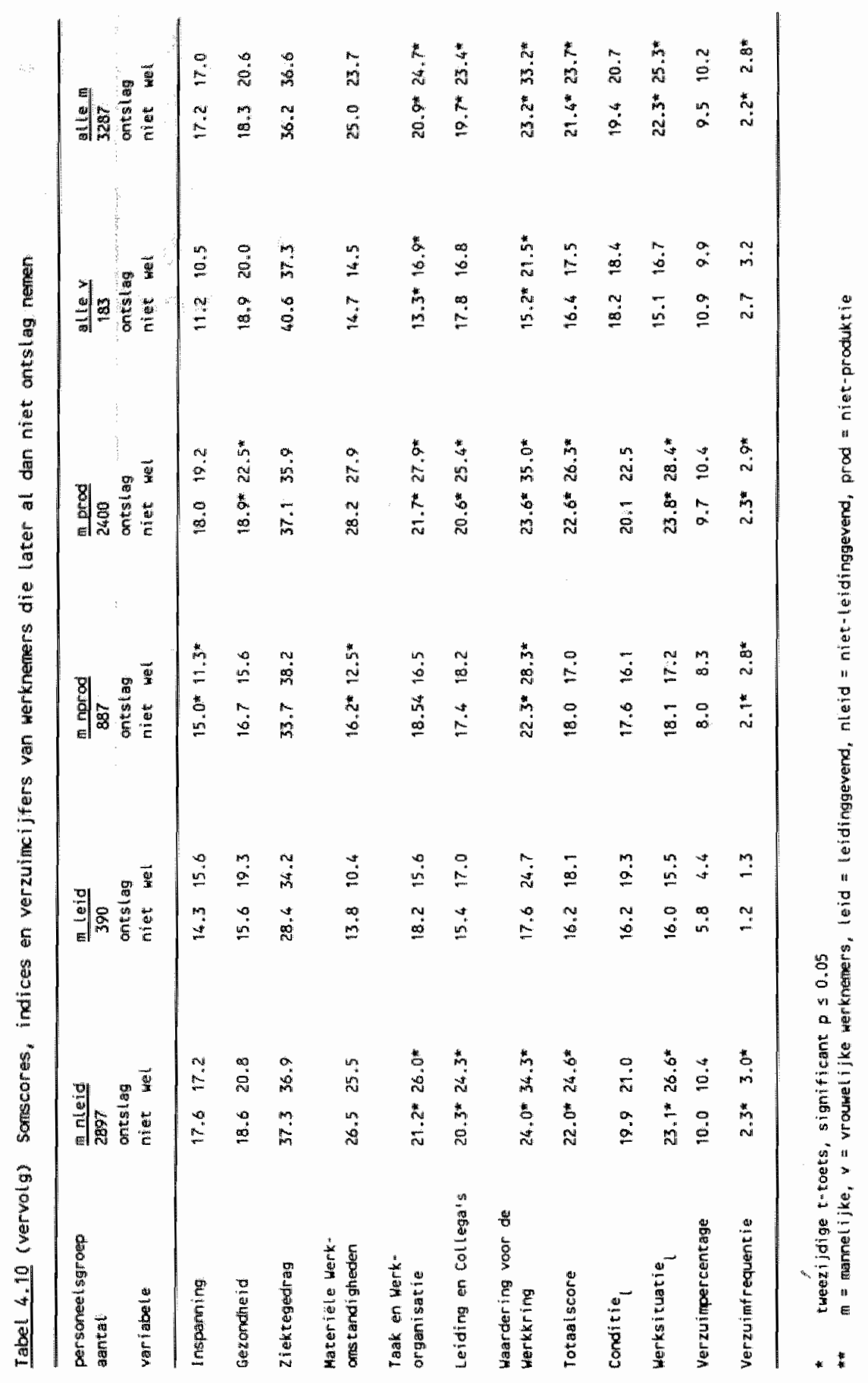


Wat de indices betreft, moet dit tot uiting komen in Werksituatie; ditie $_{1}$. Werksituatie, heeft in vijf groepen een significant verschil d.w.z. viermaal met meer problemen in de ontslaggroep en eenmaal (mannen $50+$ ) andersom. De laatste vormt blijkbaar een uitzondering en we kunnen ons beter richten op de overige vier groepen werknemers. Daarbinnen is het verschil tussen wel- en niet-ontslag het grootst bij de mannelijke produktiewerknemers. We zullen deze groep, die opgevat kan worden als de modale werknemer, verderop in paragraaf 4.3 .3 en 4.3 .4 als voorbeeld nemen.

\subsubsection{Variabelen in de tijd voor ontslagname}

De somscores, indices en verzuimeijfers van de werknemers die in de jaren vanaf het bedrijfsonderzoek ontslag namen geven geen duidelijke toe- of af name in de tijd te zien (cijfers ter inzage bij de auteur). Vermoedelijk speelt hierbij mee, dat de aantallen werknemers per jaar hier laag zijn (die aantallen lopen bij de somscores van 13 tot 128 en bij de verzuimcijfers van 3 tot 163), zodat geen stabiele schattingen mogelijk zijn.

\subsubsection{Ontslagname: voorspellend vermogen per variabele}

De twaalf variabelen van de vorige paragraaf bleken niet allemaal even veelbelovend te zijn als woorspellers van ontslagname. Om die reden worden njet de incidentiedichtheidsratio's (IDR's, zie paragraaf 3.11 ) van alle twaalf verklarende variabelen gegeven, maar slechts van een viertal. De best differentiërende variabelen (paragraaf 4.3.1) zijn bij ontslagname Taak en Werkorganisatie, Waardering Werkkring, Werksituatie, en de verzuimfrequentie; deze worden hieronder gepresenteerd. Om vast te kunnen stellen wat de invloed op de IDR is van de grens die tussen de lage en de hoge scores getrokken wordt, zijn tentatief een aantal grenswaarden aangehouden (bijlage 5). De resultaten wat betreft ontslagname geeft tabel 4.11 . 


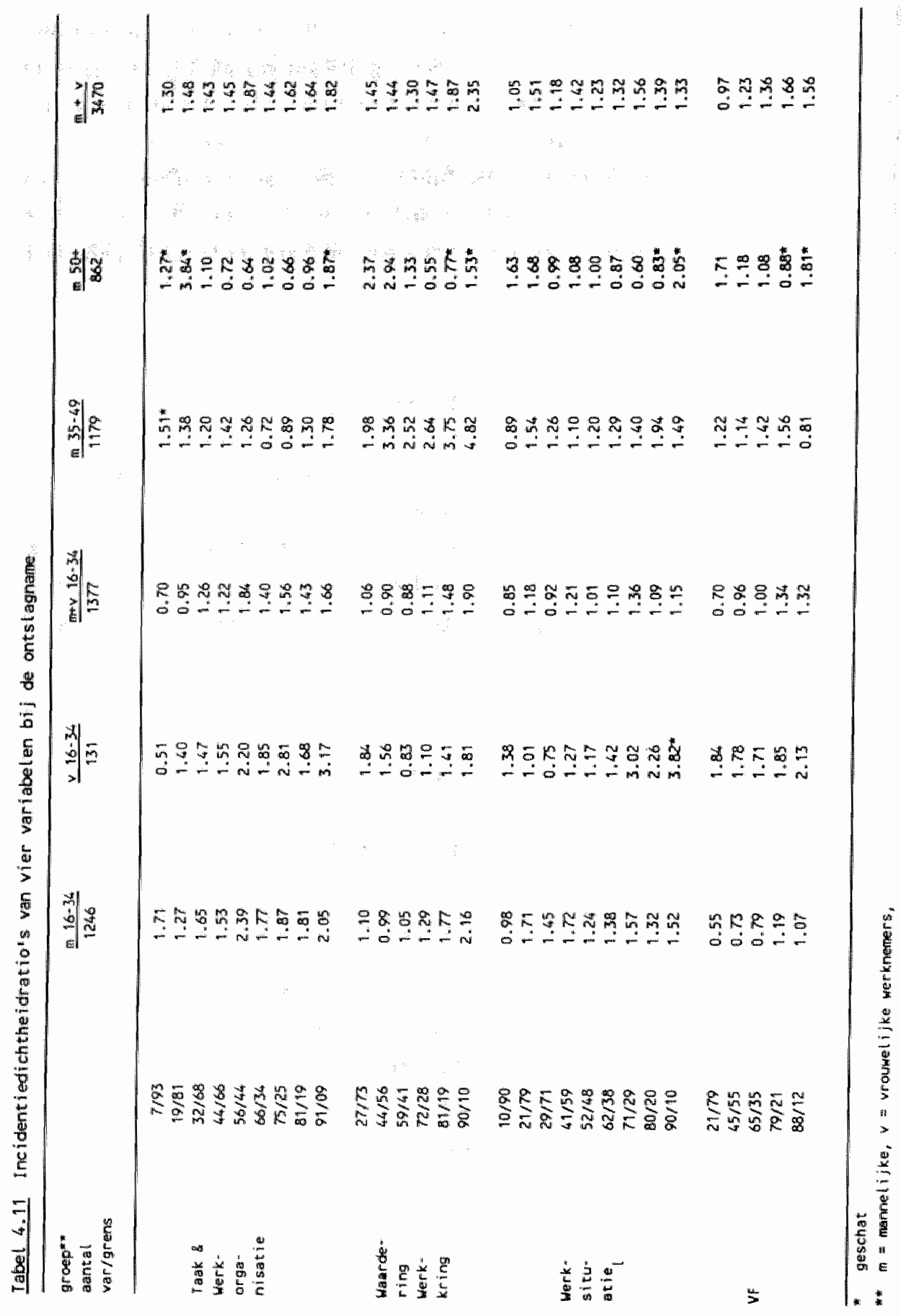




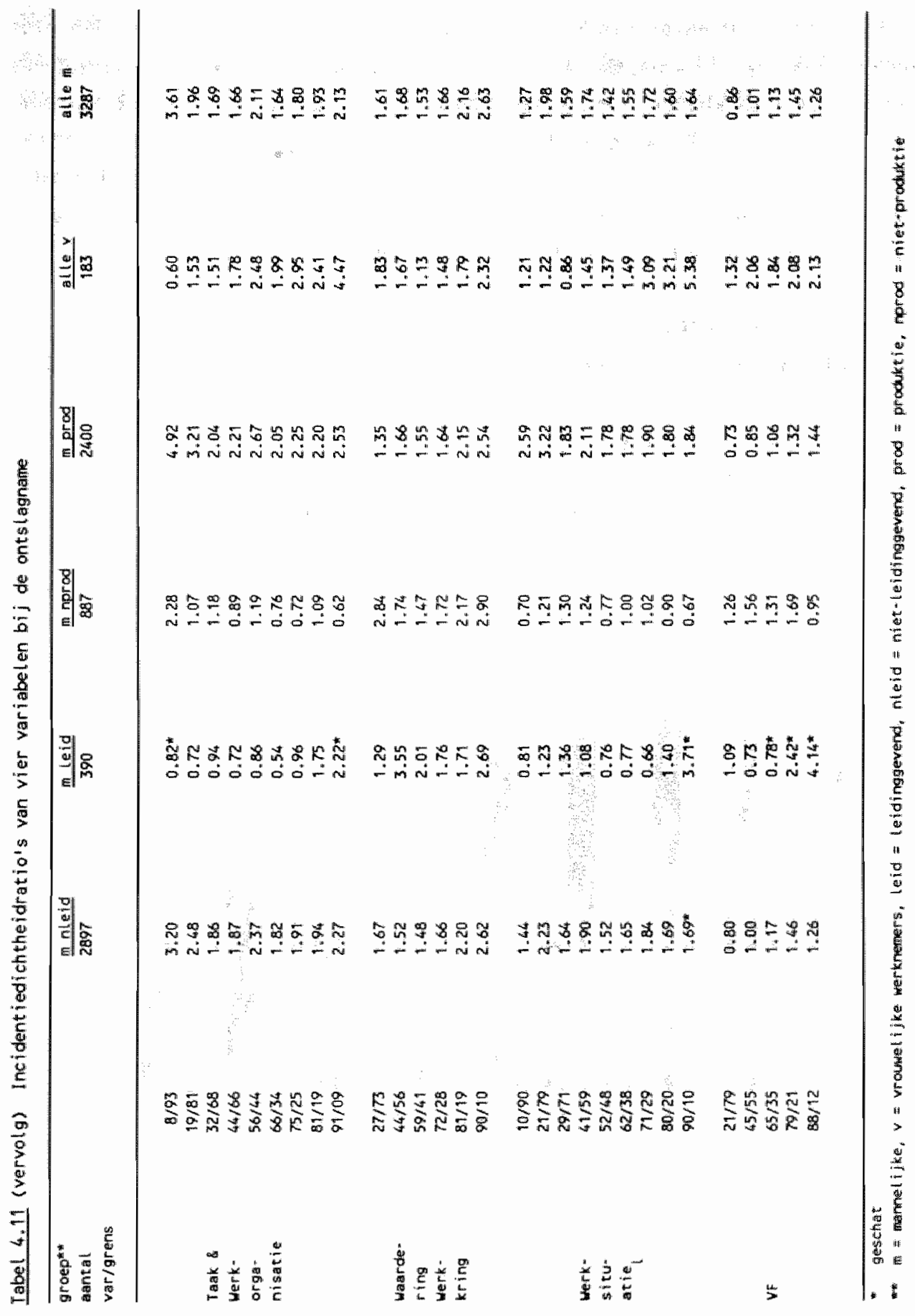


Om een indruk te geven van het bereik wan deze IDR"s: nemen we waarden van 0.50 en 2.00 als criterium, dan komen er 64 boven een waarde van twee uit; geen enkele is 0.50 of kleiner. Naar verhouding komen de meeste IDR's van 2 of meer voor bij Taak en Werkorganisatie (28 van de 108 IDR's) en bij Waardering Werkkring (22 wan de 73). De laatste twee zijn door de bank genomen blijkbaar beter voorspellers van ontslagname dan Werksituatie (12 van de 208 IDR's zijn 2 of hoger) en Verzuimf requentie (6 van de 60 IDR's).

\section{Sensiltiviteit en specificiteit}

De sensitiviteit en specificiteit (zie paragraaf 3.11) van de beschouwde variabelen worden wat betreft de ontslagname vermeld in bijlage 8. De index Werksituatie, wordt hier als voorbeeld opgevoerd om het verloop van sensitiviteit en specificiteit met de ligging van de grenswaarde in de voorspeller (zie paragraaf 3.11) te laten zien. De groep hier zijn de mannelijke werknemers in de produktieafdelingen.

Fiquur 4.4 Sensitiviteit en specificiteit van de index Werksituatie bij de ontslagname, mannellike werknenters produkt ie (2ie bijlage $8, n=2400$ )

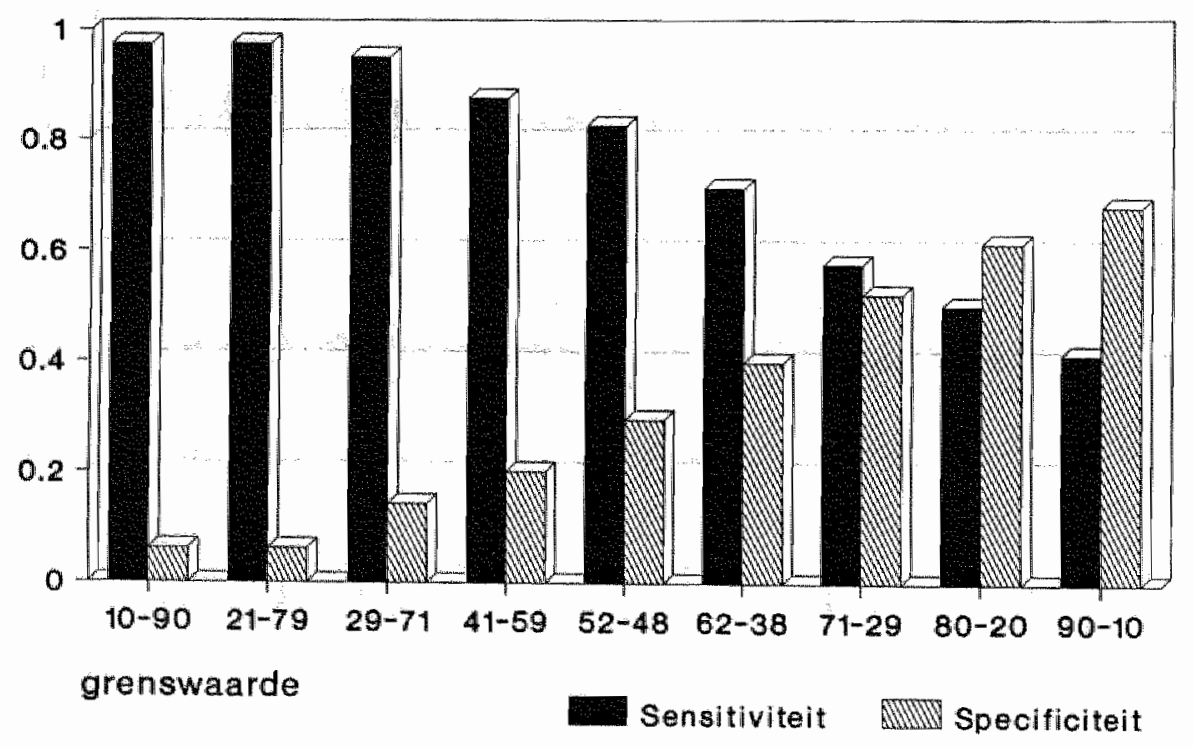


Het is duidelijk dat het niet mogelijk is, een hoge sensitiviteit en een hoge specificiteit tegelijk te bereiken. De mogelijkheid tot individueel voorspellen van ontslagname is daardoor beperkt.

\subsubsection{Ontslagname: voorspelling uit werknemersmeningen en verzuimgegevens}

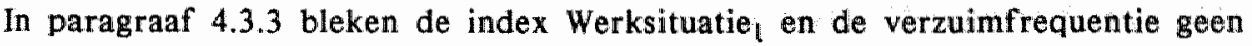
echt goede, maar misschien bruikbare voorspellers van ontslagname. Daarom wordt hieronder nagegaan wat hun gezamenlijke voorspellende vermogen is.

\section{Logistische regressie}

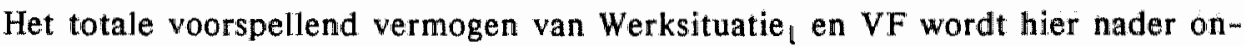
derzocht met behulp van logistische regressie (zie paragraaf 3.11). Bij de formule hieronder staat $y$ voor log odds van ontslagname, $x_{1}$ voor de index Werksituatie en $\mathrm{x}_{2}$ voor de verzuimfrequentie:

$$
y=-3.35+0.63 x_{1}-0.11 x_{2}
$$

De chi kwadraat bereikt een significante waarde, zodat de conclusie moet zijn, dat het hier beproefde model niet goed past bij de gegevens. Wel kunnen we nog nagaan, wat de werkelijke en de door het modell voorspelde kansen van ontslagname (odds, zie paragraaf 3.11 ) zijn bij de verschillende niveaus van de voorspellende variabelen.

Iabel 4.12 Haargenomen voorspelde adds bij ontslagname, voorspelling til Werksitua* tiel en verzuimfrequentie, manner in produktieafolingen (n:2400)

\begin{tabular}{llllll}
\hline \multirow{2}{*}{$\begin{array}{l}\text { Werksi- } \\
\text { tuatiel }\end{array}$} & $\begin{array}{l}\text { Verzuim- } \\
\text { frequentie }\end{array}$ & $\begin{array}{l}\text { warge- } \\
\text { nomen }\end{array}$ & $\begin{array}{l}\text { voor- } \\
\text { spelld }\end{array}$ & $\begin{array}{l}\text { sensiti- } \\
\text { viteit** }\end{array}$ & $\begin{array}{l}\text { specifi- } \\
\text { teft** }\end{array}$ \\
\hline L* & $L$ & 0.07 & 0.06 & 0.64 & 0.35 \\
$L$ & $H$ & 0.04 & 0.05 & 0.36 & 0.72 \\
$H$ & $L$ & 0.06 & 0.11 & 0.29 & 0.84 \\
$H$ & $H$ & 0.12 & 0.10 & & \\
\hline
\end{tabular}

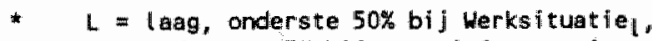

$L=$ onderste $45 \%$ bij verzuinfrequentie; zie bijlage 5 voor de ligging van de grenzen ** Bij respectievelijk LL tegenover rest, $L L$ en $L H$ tegenower rest en $L L$, $L / H$ en $H L$ tegenover HH. 
Of de voorspellende variabele hoog of laag is, maakt weinig uit in de odds, dus ook weinig in de kans op latere ontslagname. Die kans is en blijft laag; ook bij het inzetten van twee voorspellers tegelijk walt het latere ontslag individueel niet goed te voorspellen.

\section{Sensitiviteit en specificiteit}

Stellen we in tabel 4.12 de combinatie hoog - hoog (HH) tegenover de drie andere, dan blijkt dat weliswaar de specificiteit 0.84 is, maar de sensitiviteit 0.29 . Bijna alle niet-ontslagnemers zitten in de combinaties $L L, L H$ en $L L$, maar slechts een klein deel van degenen die wél ontslag zouden nemen, hebben beide voorspeliers hoog (HH). Dit betekent dat ook met twee variabelen tegelijk de de ontslagname niet goed individueel voorspelbaar is.

\subsubsection{Ontslagname en lange VAG: discussie}

Drie aspecten van de resultaten wat betreft ontslagname komen aan de orde, net als bij de eerder behandelde vertrekwijzen: de overeenstemming tussen uitkomsten en literatuur, de mogelijkheden tot voorspelling van ontslagname en tenslotte de validiteit van de $V A G$, de gebruikte vragenlijst.

\section{Overeenstemming met de literatuur}

Twee verwachtingen werden in paragraaf 2.5 .3 geformuleerd: ontslag zou voornamelijk bij jeugdige werknemers te zien zijn en alle verklarende variabelen, in het bijzonder de werkvariabelen, zouden positief samen kunnen hangen met ontslagname (meer verzuim en problemen in de ontslaggroep dan in de vergelijkingsgroep).

Het eerste is in paragraaf 3.9 .1 al gebleken, want de meeste ontslagnamen komen voor in de groep 19 - 34 jaar, veel minder in de groep 35 - 49 jaar en vrijwel geen in de groep van vijftig jaar en ouder. Het beschikbare materiaal bevestigt dus wat leeftijd betreft de verwachting op grond van de literatuur.

Wat betreft de enquetegegevens (dus somscores en indices in tabel 4.10) bleek, dat maar een deel hiervan samenhangt met de latere ontslagname. Daarbij is 
soms $(34 \mathrm{x}$ ) de richting van het verschil in overeenstemming met de richting die de literatuur aangeeft, namelijk meer problemen bij de ontslaggroep, maar ook ligt het wel andersom $(6 \mathrm{x})$. Tachtig verschillen zijn statististisch niet significant.

We kunnen ons ook afvragen, wat de resultaten van de modale werknemer in tabel $4.12 \mathrm{zijn}$. Nemen we voor die groep de niet-leidinggevende mannelijke en de produktiewerknemers, dan zijn er een aantal significante verschillen die dezelfde richting op wijzen als de literatuur: problemen met de gezondheid, met tak en werkorganisatie, leiding en collega's en de totalscore. Daardoor is ook de index Werksituatie, ${ }_{1}$ hoger (meer problemen) in de ontslaggroep dan in de niet-ontslaggroep. Tot slot is ook de verzuimfrequentie (maar niet het verzuimpercentage) in beide groepen (niet-leiding en produktie) in de door de literatuur verwachte richting. De conclusie uit de literatuur dat vooral de werkvariabelen relatief hoog zouden moeten zijn in de ontslaggroep is dus voor de modale werknemer bevestigd. De eindconclusie moet daarom zijn, dat de literatuur met betrekking tot ontslagname gedeeltelijk door de gegevens bevestigd wordt.

\section{Voorspelbaarheid van ontslagname}

Het aantonen van verschillen tussen groepen die wel respectievelijk niet ontslag namen is nog niet hetzelfde als het voorspellen of een individuele werknemer gezien zijn VAG-scores en verzuim zall vertrekken. Het bleek, dat slechts voor een deel van de verklarende variabelen zulke verschillen op groepsniveau aanwezig zijn, soms in de ene richting (ontslaggroep hoog) en soms in de andere (vergelijkingsgroep hoog). Bovendien bleek dat, waar zulke verschillen aanwezig zijn, de kracht van de individuele voorspelling in termen van sensitiviteit en specificiteit, (zie bijlage 8) gering is. Zellfs als er twee voorspellers tegelijk gebruikt worden (verzuimfrequentie en de index Werksituatie l $_{\text {) }}$ is er niet van een bruikbare individuele voorspelling sprake.

Met de aanwezige variabelen, d.w.z. werknemersmeningen en verzuimgegevens, blijkt ontslagname individueel dus niet goed voorspelbaar te zijn. Waarschijnlijk betekent dit dat het actuele verzuimgedrag en de actuele arbeidssituatie maar een geringe invloed hebben op de beslissing tot ontslagname van de werknemer. Het kan ook betekenen dat de belangrijkste determinerende factoren gelegen zijn in de verwachte situatie na de ontslagname (bijv. een nieuwe werkkring, huwelijk, 
geboorte van een kind). Soms proberen werkgevers door middel van "exit-interviews" van vertrekkende werknemers te weten te komen, wat de motieven voor de ontslagname zijn. Als de laatste interpretatie juist is (belangrijkste determinanten buiten de oude werksituatie), dan zal bij exit-interviews blijken, dat het motief voor ontslagname maar voor een klein deel te herleiden is tot ongunstige aspecten van de oude werksituatie.

Tenslotte is het ook niet uitgesloten, dat ontslagname niet met de oude werksituatie of met de nieuwe werk- of levenssituatie te maken heeft, maar met de behoefte aan verandering. Sommige carrièretheorieën (bijvoorbeeld Super, 1957, 1968) nemen aan dat er een levensperiode is waarin men van nature, zonder dat het veel zegt over de kwaliteit van de ene of de andere betrekking, vaak verandert van werksituatie. Wat ook de verklaringen mogen zijn, feit blijft, dat ontslagname niet individueel, maar hoogstens op groepsniveau te voorspellen is.

\section{Validiteit van de VAG}

In de eerste plats werd gevonden dat hoge scores op enkele onderdelen van de VAG (Gezondheid, Taak en Werkomstandigheden, Leiding en Collega's, totaalscore) samengaan met een hogere verzuimfrequentie in de ontslaggroep. Dit vormt een argument voor de convergente validiteit van de VAG. Verder werd aangetoond dat binnen de groep niet-leidinggevende mannen in de productie de zelfde onderdelen van de VAG een zekere individuele voorspelling van latere ontslagname mogelijk maken. Perfect is deze voorspelling niet, maar dat is ook moeilijk te verwachten omdat er naast de actuele werksituatie velle andere motieven meespelen, zoals hiervoor al werd aangevoerd. Omdat voorspelling van vertrek (in dit geval ontslagname) en predictieve validiteit van de VAG de praktische en de theoretische kant van dezelfde woorspelling zijn, mogen we concluderen dat de resultaten steun geven aan de validiteit van de VAG.

\subsection{Lange VAGr: algemene discussie}

Wat is nu de waarde van de gevonden voorspellingen? Is de hoogte van de kansverhouding (de IDR) hier doorslaggevend? Karasek e.a. (1987) nemen als maatstaf de hoogte van de odds ratio (OR) van de relatie roken - hartziekten (de ver- 
houding hartziekten : niet-hartziekten in het rokende deel ten opzichte van dezelfde verhouding in het niet-rokende deel van de bevolking). Deze OR is kleiner dan 0.76 of groter dan 1.32 . We zouden dezelfde grenzen kunnen aanhouden voor onze IDR's.

De voorspellingen bij arbeidsongeschiktheid (IDR"s in tabel 4.3) voldoen vrijwel allemaal ruim aan dit criterium, bovendien zijn sensitiviteit en specificiteit hier behoorlijk. De IDR's bij vervroegd uittreden (tabel 4.8 ) voldoen eveneens aan het genoemde criterium, maar daarbij zijn sensitiviteit en specificiteit te laag voor individuele voorspellingen. Bij ontslagname (tabel 4.11) bereikt ongeveer $70 \%$ van de IDR's het criterium van Karasek e.a., maar daar blijkt de voorspelling (in termen van sensitiviteit en specificiteit) toch niet geheel te voldoen. We kunnen hieruit twee conclusies trekken:

1) In vergelijking met de sterkte van de relatie roken - hartziekten is de sterkte van de voorspellingen aan de hand van de VAG behoorlijk en soms erg goed, of het nu gaat om arbeidsongeschiktheid, VUT of ontslagname.

2) Kijken we echter ook naar de verdere eigenschappen van de individuele voorspelling (sensitiviteit en specificiteit) dan blijkt arbeidsongeschiktheid wel, maar VUT en onstslagname niet goed individueel te voorspellen te zijn.

De VAG is dus geschikter om vroege individuele signalen van arbeidsongeschiktheid op te sporen, dan om naderende VUT of ontslagname van een werknemer gemeld te krijgen.

We kunnen ons verder daarom beperken tot de arbeidsongeschiktheid. De kans op arbeidsongeschiktheid neemt in het algemeen sterk toe met de hoogte van de index Conditie, en van het verzuimpercentage. Tabel 4.3 liet zien dat deze twee variabelen elkaar vaak in voorspellende kracht niet veel ontiopen. Er blijkt echter bij nadere analyse (logistische regressie, paragraaf 4.1.4) dat met toenemende leeftijd van de werknemers, het voorspellend vermogen wan het verzuimpercentage afneemt en dat van de index Conditie, toeneemt. We weten verder (paragraaf 2.2.6 en 3.9.1) dat veruit de meeste arbeidsongeschiktheid optreedt in de groep werknemers van boven de 50 jaar. Will men de arbeidsongeschiktheid op een doeltreffende manier bestrijden, dan zal men dat in de eerste plaats in deze groep werknemers moeten doen en daarbij kan men gezien het voorgaande, 
het best gebruik maken van de lange VAG, althans de index Conditie die daar deel van uitmaakt.

Verder werd in de discussie onder 'arbeidsongeschiktheid" al angevoerd, dat bij de voorspelling in de praktijk een keuze gemaakt moet worden, war men de grens tussen lage en hoge scores trekt. Daarbij dient gegeven de beschikbare middelen, afgewogen te worden, hoeveel 'loos alarm' men aanvaardbaar vindt (hoogscoorders/langverzwimers die niet arbeidsongeschikt zullen worden, maar aan wie wel aandacht besteed wordt) en hoeveel latere arbeidsongeschikten men over het hoofd zou mogen zien. Los van enige concrete situatie kan deze beslissing niet genomen worden. Appels (1975) en Sturmans (1984) wijzen erop dat deze keuze afhangt van een aantal praktische factoren, waaronder de capaciteit om aandacht te besteden aan werknemers met toenemende problemen, de opvattingen van de beleidmakers en die van de hulpverleners. Daarbij zouden de werknemers systematisch betrokken kunnen worden in de formulering van het bedrijfsgezondheidsbeleid (Ramirez en Leemans, 1985). Kortom, welk niveau van voorspellers men kiest is een beleldsbeslissing, waarvoor de hier in de voorspellers gelegde grenzen indicaties geven.

Afgezien van zulke overwegingen is van de VAG met name de index Conditie een valide voorspeller van arbeidsongeschiktheid gebleken. Het blijkt mogelijk om aan de hand van VAG-gegevens, al dan niet samen met verzuimgegevens (het verzuimpercentage), al jaren van tevoren naderende arbeidsongeschiktheid op te sporen bij de individuele werknemer. Het is zodoende mogelijk met behulp wan VAG-gegevens tijdig maatregelen te nemen om arbeidsongeschiktheid te voorkömen. Welke maatregelen in het individuele geval moeten worden getroffen, hangt eventueel af van gericht probleemoplossend onderzoek bij de werknemers die door de VAG-procedure zijn aangewezen. 
De Vragenlijist Arbeid en Gezondheid (VAG) is beschikbaar in een lange en een korte versie (paragraaf 3.6 resp. 3.7). De lange versie theeft, nast een aantal beschrijvende vragen, 117 waarderende vragen die de basis zijn voor een aantal somscores die elk een aspect van het werk en de gezondheid beschrijven (paragraaf 3.6.1). Om praktische redenen, vooral de tijd benodigd voor de afname, is er ook een korte versie van de VAG ontwikkeld, die 41 vragen telt (zie voor de eigenschappen van de korte VAG paragraaf 3.7). Deze geeft meer globale informatie in twee somscores over het werk en de gezondheid en een totaalscore.

Voor de overzichtelijkheid worden de uitkomsten - wat betreft de voorspelbaarheid van vertrek uit het werk met behulp van de korte $\mathrm{VAG}$ - afzonderlijk hier in hoofdstuk 5 behandeld, na de uitkomsten van de lange VAG in hoofdstuk 4. De bewerkingen op het materiaal zijn in hoofdstuk 4 en 5 in grote trekken dezelfde, zodat de indeling hieronder parallel loopt aan het vorige hoofdstuk.

De eenenveertig vragen van de korte VAG zijn onderverdeeld in veertig detailvragen en éên totaalwaardering van de arbeidssituatie. De gevraagde werknemersmeningen worden samengevat in twee indices Conditie ${ }_{k}$ en Werksituatie $_{k}$ ( $k$ van korte versie), door de percentages problemen/klachten per onderwerp te berekenen. Hoe hoger de index, hoe meer problemen. Conditie ${ }_{k}$ is het gezondheidsdeel met 15 vragen, Werksituatie ${ }_{k}$ heeft betrekking op de arbeidssituatie en telt 25 vragen. Daarnaast zijn de veertig vragen samengevat als totaaiscore (VAG-kort). De betrouwbaatheid en de validiteit van de korte VAG en zijn onderdelen (paragraaf 3.7.3) zijn bevredigend.

In dit hoofdstuk worden zowel de korte VAG als geheel (VAG-kort), als de twee componenten ervan, nl. Conditie ${ }_{k}$ en Werksituatie $_{k}$ gebruikt bij het voorspellen van vertrek uit het werk. 
5.1.1 Verschillen tussen niet-en wel-arbeidsongeschikten

De korte VAG geeft wat betreft arbeidsongeschiktheid in drie van de zeven groepen aanmerkelijke verschillen te zien (tabel 5.1). Daarentegen geeft Conditie $e_{k}$ binnen alle groepen werknemers flinke verschillen te zien tussen de wel- en de niet-arbeidsongeschikt geworden werknemers. Steeds hebben daarbij de vertrokkenen hogere gemiddelden dan de niet-vertrokkenen. Werksituatie $k_{k}$ heeft maar in drie groepen significante verschillen, maar dan in omgekeerde richting, dus meer klachten bij de niet-vertrokkenen. Dit is het geval in de grootste subgroepen (allen, niet-leidinggevenden en produktie). Dit werd ook bij de lange versie van de VAG gevonden (paragraaf 4.1.1). Deze verschillen zijn te herleiden tot de tegengestelde verbanden van Conditie $e_{k}$ en Werksituatie ${ }_{k}$ met leeftijd (zie figuur 3.7), want binnen de leeftijdsgroepen $35-49$ en $50+$ jaar zijn dergelijke verschillen niet meer aanwezig. We kunnen aan de hand van tabel 5.1 concluderen, dat alleen de index Conditie $_{k}$ een goede voorspeller van arbeidsongeschiktheid zou kunnen zijn. 


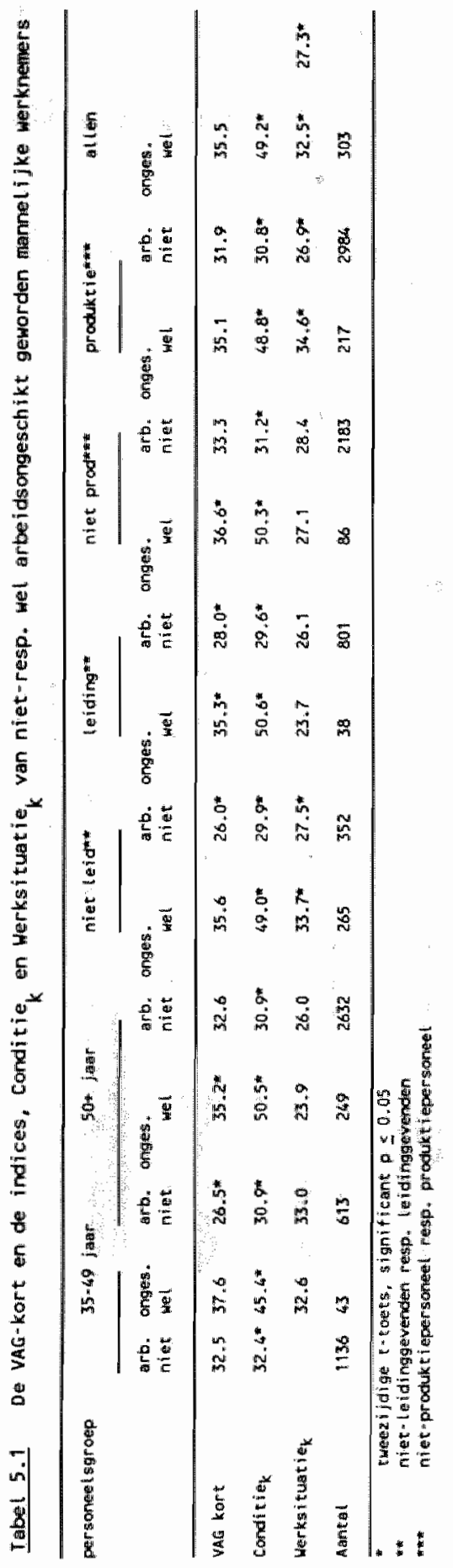




\subsubsection{Arbeidsongeschiktheid: voorspellend vermogen korte VAG}

De voorspellende waarde van de korte VAG, Conditie ${ }_{k}$ en Werksituatie $_{\mathrm{k}}$ is aangegeven in tabel 5.2 .

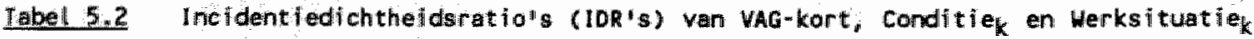
bil arbeidsongeschiktheid (mannel ijkerknemers)

\begin{tabular}{|c|c|c|c|c|c|c|c|c|}
\hline \multicolumn{2}{|c|}{$\begin{array}{l}\text { groep* } \\
\text { grens/aantal }\end{array}$} & $\begin{array}{l}35-49 \\
1179\end{array}$ & $\begin{array}{l}50+ \\
862\end{array}$ & $\begin{array}{l}\text { leiding } \\
390\end{array}$ & $\begin{array}{l}\text { nifet- } \\
\text { teiding } \\
2897\end{array}$ & $\begin{array}{l}\text { produc- } \\
\text { tie } \\
2400\end{array}$ & $\begin{array}{l}\text { niet- } \\
\text { produktie } \\
887\end{array}$ & $\begin{array}{l}\text { totaal } \\
3287\end{array}$ \\
\hline & $12 / 88$ & 0.56 & 2.83 & 1.36 & 1.29 & 1.04 & 2.19 & 1.30 \\
\hline & $22 / 78$ & 0.85 & 2.25 & 1.68 & 1.20 & 1.07 & 1.84 & 1.25 \\
\hline & $32 / 68$ & 0.87 & 2.11 & 2.18 & 1.00 & 0.88 & 1.95 & 1.10 \\
\hline VAG & $42 / 58$ & $0_{.48} 98$ & 1.99 & 1.94 & 0.95. & 0.84 & 1.79 & 1.04 \\
\hline \multirow[t]{7}{*}{ kort } & $48 / 52$ & 1.12 & 2.05 & 2.45 & 0.98 & 0.89 & 1.92 & 1.10 \\
\hline & $58 / 42$ & 1.39 & 2.17 & 2.27 & 1.114 & 1.03 & 2.06 & 1.23 \\
\hline & $68 / 32$ & 1.21 & 1.80 & 2.27 & 1.03 & 0.97 & 1.71 & 1.12 \\
\hline & $80 / 20$ & 1.64 & 1.67 & 3.04 & 0.95 & 0.86 & 1.99 & 1.07 \\
\hline & $90 / 10$ & 1.44 & 1.44 & 2.64 & 0.72 & 0.76 & 0.99 & 0.80 \\
\hline & $10 / 90$ & 3.54 & 6.75 & 3.37 & 4.76 & 18.56 & 1.73 & 4.53 \\
\hline & $20 / 80$ & 3.18 & 4.72 & 10.19 & 3.25 & 4.70 & 2.42 & 3.61 \\
\hline Con & $30 / 70$ & 2.35 & 6.33 & 4.88 & 4.43 & 5.37 & 3.35 & 4.48 \\
\hline di- & $40 / 60$ & 2.51 & 5.03 & 2.89 & 4.27 & 4.29 & 3.58 & 4.03 \\
\hline \multirow[t]{7}{*}{ tiek } & $50 / 50$ & 2.85 & 4.61 & 3.05 & 4.40 & 4.15 & 4.36 & 4.19 \\
\hline & $60 / 40$ & 2.06 & 4.37 & 3.38 & 4.06 & 3.68 & 4.83 & 3.96 \\
\hline & $70 / 30$ & 2.43 & 4.54 & 4.42 & 4.16 & 4.05 & 4.61 & 4.19 \\
\hline & $80 / 20$ & 2.28 & 4.29 & 5.32 & 4.18 & 4.28 & 4.39 & 4.31 \\
\hline & $90 / 10$ & 2.78 & 3.18 & 3.13 & 4.15 & 3.54 & 5.25 & 3.98 \\
\hline & $10 / 90$ & 0.50 & .87 & 0.67 & 0.47 & 0.34 & 1.21 & 0.50 \\
\hline & $20 / 80$ & 0.60 & 1.31 & 1.99 & 0.56 & 0.46 & 1.57 & 0.66 \\
\hline Werk - & $30 / 70$ & 0.81 & 1.38 & 1.67 & 0.60 & 0.49 & 1.57 & 0.69 \\
\hline situ- & $40 / 60$ & 0.91 & 1.31 & 1.33 & 0.56 & 0.49 & 1.17 & 0.62 \\
\hline \multirow[t]{5}{*}{$\operatorname{atie}_{k}$} & $50 / 50$ & 0.99 & 1.24 & 0.97 & 0.57 & 0.49 & 1.09 & 0.61 \\
\hline & $60 / 40$ & 0.86 & 1.27 & 0.94 & 0.58 & 0.53 & 0.94 & 0.61 \\
\hline & $70 / 30$ & 1.13 & 1.33 & 1.27 & 0.60 & 0.55 & 1.05 & 0.64 \\
\hline & $80 / 20$ & 1.36 & 1.30 & 2.17 & 0.56 & 0.52 & 1.09 & 0.61 \\
\hline & $90 / 10$ & 1.48 & 1.04 & 3.43 & 0.44 & 0.34 & 1.28 & 0.47 \\
\hline
\end{tabular}


De getallen in de tabel hierboven (incidentiedichtheidsratio"s, IDR's, zie paragraaf 3.11) geven aan hoeveel meer kans een werknemer met een hoge score heeft op arbeidsongeschiktheid dan eên met een lage score. Bij de korte $\mathrm{VAG}$, voor Conditie $_{k}$ loopt die kans van ongeveer 2 tot 18 en voor Werksituatie $e_{k}$ van ongeveer van 0.50 tot 1.50. Arbeidsongeschiktheid zou dus vooral voorspellers hebben in problemen wat met inspanning en gezondheid (Conditie ${ }_{k}$ ).

Hoe precies zijn deze voorspellingen? $\mathrm{Er}$ is uitgerekend welk deel van de hoogscorende werknemers inderdaad arbeidsongeschikt wordt en welk deel van de laagscorenden niet arbeidsongeschikt wordt (sensitiviteit resp. specificiteit, zie paragraaf 3.11 ). Het resultaat is te zien in bijlage 6 ; figuur 5.1 hieronder laat voor de index Conditie $_{k}$ zien hoe deze twee grootheden samenhangen met de plaats waar men de grens trekt tussen lage en hoge scores. Als voorbeeld is (net als in paragraaf 4.1.3) de groep mannelijke werknemers van 50 jaar en ouder genomen.

Elquer 5.1 Sensitiviteit en specificiteit wan conditile bij arbeidsongeschiktheid cmanne lijke werknemers, $50+$ jaalm: $h=862$ )

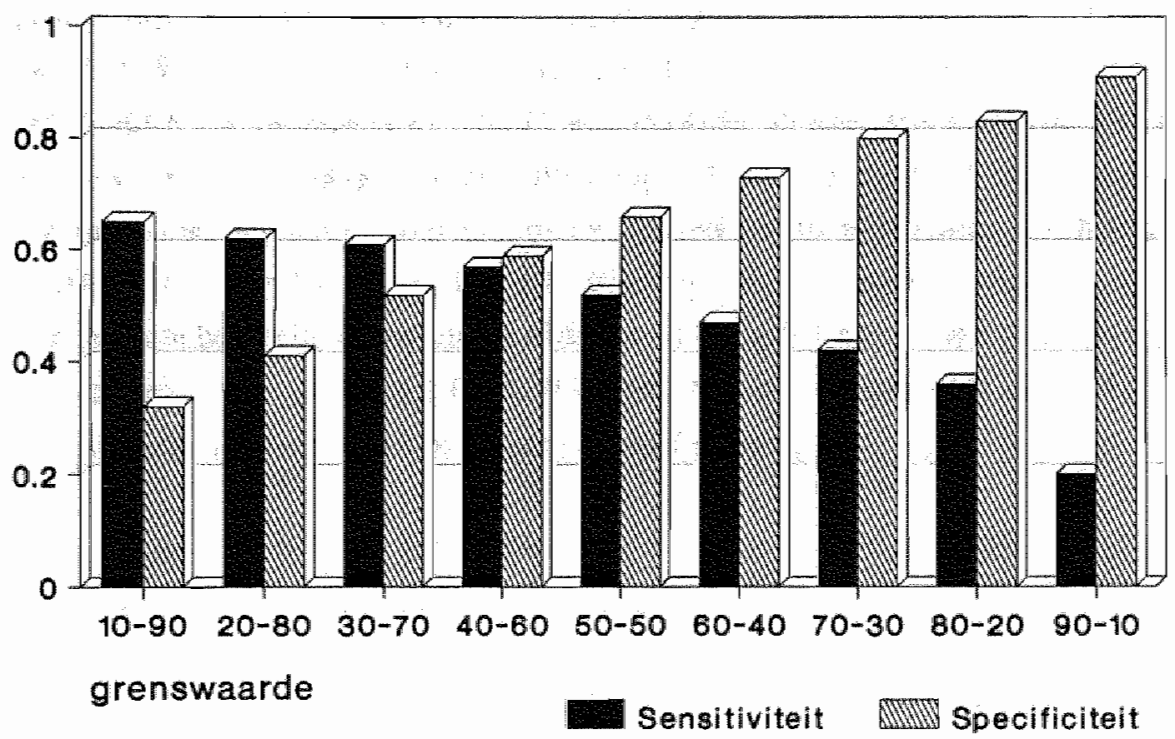


Leggen we de grens laag (de onderste 10\% tegenover de bovenste $90 \%$ ), dan omvat de hoogscorende groep veel van de latere arbeidsongeschikten (65\%), maar lage scores hebben weinig te maken met niet-arbeidsongeschiktheid $(32 \%$ van de niet-arbeidsongeschikten heeft zo een lage score). Schuiven we deze grens omhoog, dan daalt het aantal woorspelde arbeidsongeschikten en stijgt het aantal voorspelde niet-arbeidsongeschikten. De voorspelling is zodoende niet perfect maar, naar het zich laat aanzien, wel bruikbaar; zie de discussie in paragraf 5.1.4.

\subsubsection{Arbeidsongeschiktheid: voorspelling uit korte VAG en verzuimgegevens}

We hebben gezien, dat Conditie $_{k}$ op zichzelf een voorspelling van arbeidsongeschiktheid mogelijk maakt. In paragraaf 4.1 .3 bleek, dat van de verzuimgegevens het verzuimpercentage de meeste voorspellende kracht heeft wat arbeidsongeschiktheid betreft. We gaan daarom hier na wat er gebeurt, als Conditie $_{k}$ en verzuimpercentage tegelijk als voorspeller gebruikt worden. Niet alle grenswaarden in beide voorspellers kunnen worden getoond (zie bijlage 5); alleen een voorbeeld kan worden gegeven. We kiezen daarvoor de grens bij Conditie zowel als bij het verzuimpercentage net als in paragraaf 4.1 .4 bij de onderste $80 \%$ tegenover de bovenste $20 \%$ van de werknemers. Omdat in paragraaf 4.1 .4 bleek dat een model waarin leeftijd één van de voorspellers is, niet goed past, zien we hier van leeftijd als voorspeller af en bezien we in plaats daarvan de samenhangen binnen de drie leeftijdsgroepen afzonderlijk. (Wat de technische kant betreft: er wordt gebruik gemaakt van logistische regressie en er wordt niet gedacht in termen van kansen, maar van 'odds", zie paragraaf 3.11). 
Tabel 5.3 Wargenomen en voorspelde odds bij arbeidsongeschiktheid, sensitivitelt en specificiteit in drie leeftijdsgroepen, mannelijke werknemeirs, tegelijk condi. tie $\mathrm{k}$ en Verzuimpercentage

\begin{tabular}{|c|c|c|c|c|c|c|}
\hline \multirow{2}{*}{ Leeftidd } & \multirow[b]{2}{*}{ Conditie } & \multirow[b]{2}{*}{$\begin{array}{c}\text { Verzuim } \\
*\end{array}$} & \multicolumn{2}{|c|}{ odds } & \multirow[b]{2}{*}{$\begin{array}{l}\text { sensiti- } \\
\text { viteit }\end{array}$} & \multirow[b]{2}{*}{$\begin{array}{l}\text { specifi- } \\
\text { citeit }\end{array}$} \\
\hline & & & $\begin{array}{l}\text { waarge- } \\
\text { nomen }\end{array}$ & $\begin{array}{l}\text { woor- } \\
\text { speld }\end{array}$ & & \\
\hline & $L^{*}$ & $L$ & 0.004 & 0.004 & & \\
\hline & $L$ & $H$ & 0.043 & 0.049 & $\begin{array}{l}0.70 \\
0.30\end{array}$ & $\begin{array}{l}0.74 \\
0.82\end{array}$ \\
\hline $16-34$ jaar & $H$ & $L$ & 0.000 & 0.003 & 0.20 & .96 \\
\hline \multirow[t]{3}{*}{$(n=1246)$} & $H$ & H & 0.050 & 0.040 & & \\
\hline & $\iota$ & $\mathbb{L}$ & 0.019 & 0.017 & 0.65 & .67 \\
\hline & L. & $H$ & 0.075 & 0.085 & 0.40 & .77 \\
\hline $35-49$ jaar & $H$ & $L$ & 0.024 & 0.030 & 0.28 & .93 \\
\hline \multirow[t]{4}{*}{$(n=1179)$} & H & H & 0.167 & 0.151 & & \\
\hline & & & $\therefore$ & & & \\
\hline & L & $\mathbb{L}$ & 0.239 & 0.236 & 0.69 & .66 \\
\hline & $L$ & $H$ & 0.620 & 0.652 & 0.55 & .77 \\
\hline $50 *$ jear & $H$ & L & 0.805 & 0.828 & 0.29 & .94 \\
\hline$(n=862)$ & $H$ & $H$ & 2.400 & 2.293 & & \\
\hline
\end{tabular}

$L=$ laag, anderste $80 \%, H=$ hoog, bovenste $20 \%$, zie bijlage 5 vaor de ligging wan de grenzen

*** Bij respectíevelijk $L L$ tegenover rest. $L L$ en $L H$ tegenover rest en $L L$, $L H$ en HL tegenover $\mathrm{HH}$

De door het logistische model voorspelde odds zijn steeds vrijwel gelijk aan de waargenomen odds, zodat het model goed past; het is toegestaan om het te gebruiken. In de jongste groep is de kans op (de odds van) arbeidsongeschiktheid het laagst, die kans loopt via de middelste groep op tot hoog in de oudste leeftijdsgroep. Maar belangrijker is, dat binnen elke leeftijdsgroep de kansen op arbeidsongeschiktheid van boven naar beneden toenemen.

Zijn beide voorspellers laag, dan is de kans op WAO betrekkelijk laag en die kans loopt op tot de combinatie van beide woorspellers (Conditie en verzuimpercentage) hoog. Bij de aangegeven leeftijdsverschillen geldt daarom verder: hoog scoren op deze beide voorspellers geeft een veel hogere kans op arbeidsongeschiktheid dan een lage score op allebei. Die kansverhouding (odds ratio) is in elke groep ongeveer 10. 
Wat betreffende sensitiviteit en specificiteit voor de groep met de meeste arbeidsongeschikten, nl. die van $50+$ jaar (zie paragraaf 3.11 voor omschrijvingen daarvan).

Elgur 5.2 Sensitivitelt en spectfieltelt bil voorspelling van arbeidsongeschiktheid uit tegellik conditie $\mathrm{k}$ en verzuimpercentage (mannelijke werknemers, 50+ jaar; $\mathrm{n}=$ 862)

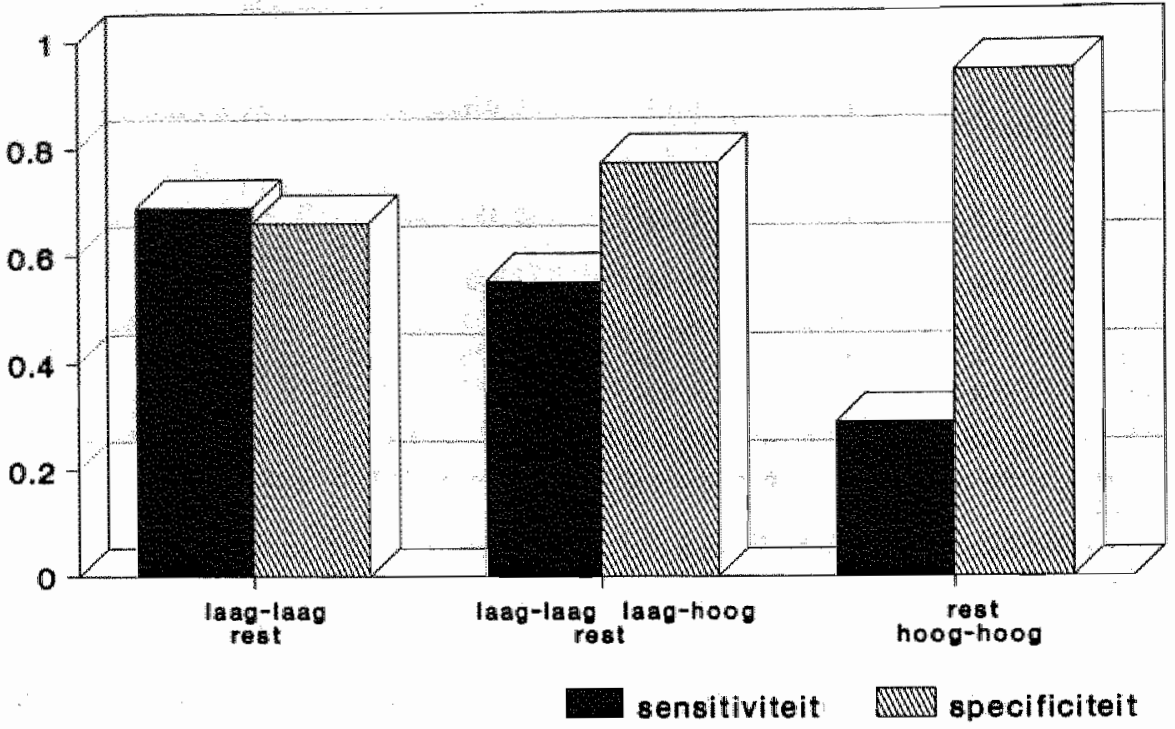

De sensitiviteit daalt in de figuur van links naar rechts van 0.69 tot 0.29 ; de specificiteit stijgt daarbij van 0.66 tot 0.94 . In praktische termen: door niet één voorspeller (Conditie $e_{k}$ ) te nemen, maar twee (bovendien het verzuimpercentage) weten we niet veel beter aan te wijzen wie er arbeidsongeschikt zal worden, maar wel wie dat niet zullen worden: vergelijk figuur 5.1. De voorspelling is daarmee scherper, nauwkeuriger geworden,

\subsubsection{Arbeidsongeschiktheid en de korte VAG: discussie}

\section{Overeenstemming met de literatuur}

De uitkomsten met de korte versie van de VAG bij het voorspellen van arbeids- 
ongeschiktheid verschillen niet van die met de lange VAG. Zie paragraaf 4.1.5: Het gaat zoals de literatuur stelt, om oudere werknemers die arbeidsongeschikt worden; dit mag geen verbazing wekken, want de uitkomsten bij lange en korte VAG zijn op dezelfde gegevens van dezelf de werknemers gebaseerd. Verder $10-$ pen ook de andere uitkomsten parallel aan de lange VAG, want de arbeidsinspanning en gezondheid (Conditie ${ }_{k}$ ) bleken arbeidsongeschiktheid te kunnen voorspellen, maar de werkomstandigheden (Werksituatie ${ }_{k}$ ) niet. Dit laatste wijkt af van de verwachting op grond van de literatuur, zoals al in paragraaf 4.1.5 werd gesteld. In paragraaf 4.1 .5 werd al een verklaring voor deze discrepantie gegeven. De relatie tussen de werkomstandigheden en arbeidsongeschiktheid loopt namelijk indirect, via de gezondheid. Slechte werkomstandigheden kunnen bij jeugdige werknemers tien, twintig jaar later leiden tot gezondheidsschade, die dan pas merkbaar bijdraagt aan de arbeidsongeschiktheid. De gegevens in dit onderzoek beslaan maar een paar jaar en kunnen daardoor niet dit hele proces weergeven. Formeel bewijs voor de indirecte invloed van de werkomstandigheden op de arbeidsongeschiktheid is daardoor op basis van het beschikbare materiaal niet te geven. Dat die invloed bestaat, lijdt echter geen twijfel.

De uitkomsten wat betreft arbeidsongeschiktheid zijn tenslotte niet te rijmen met een slijtage-opvatting, maar eerder met noties van algemene lichamelijkgeestelijke achteruitgang en met modellen die arbeidsbelasting, gebrek aan herstelmogelijkheden en ziekte met elkaar in verband brengen (Meijman, 1988; Kompier, 1988).

\section{Voorspelbaarheid van arbeidsongeschiktheid}

De korte versie van de VAG als geheel bleek geen erg goede individuele voorspeller van arbeidsongeschiktheid te zijn; om die reden werd hij gesplitst in twee delen, nl. Conditie ${ }_{k}$ (gezondheid en inspanning) en Werksituatie ${ }_{k}$ die gaat over de werksituatie. De eerste is een goede voorspeller van arbeidsongeschiktheid, de laatste kan interpretatieproblemen geven en bleek overigens geen goede voorspeller van arbeidsongeschiktheid te zijn. Eerder (paragraaf 3.7.5) bleek dat Conditie $_{\mathfrak{k}}$ toeneemt en Werksituatie $\mathrm{k}_{\mathrm{k}}$ af neemt met stijgende leeftijd. Dit was ook te zien in figuur 3.7. Hoe ouder men wordt, hoe meer problemen men heeft met de gezondheid en daardoor ook met de arbeidsinspanning. Tegelijk nemen de niet-inspanningskanten van het werk (dus van de index Werksituatie $^{\text {) af. Uit }}$ 
tabel 5.2 moet dus niet de conclusie getrokken worden, dat een laag niveau van de problemen met de werksituatie werkelijk leidt tot een hoge kans op arbeidsongeschiktheid; dit heeft alleen te maken met de leeftijd van de werknemer. Werksituatie $_{k}$ is daarom geen goede maatstaf voor werkproblemen; woor de voorspelling van arbeidsongeschiktheid kan men zich baseren op de index Conditie.

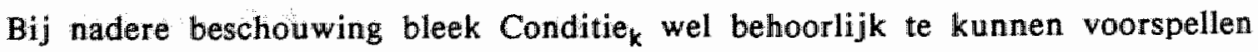
wie er arbeidsongeschikt zullen worden, maar minder goed wie dat niet zullen worden (in technische termen: de sensitiviteit ervan is goed, de specificiteit niet, zie bijlage 9). Dat leidt ertoe dat voorspelling met alleen de index Conditie ${ }_{k}$ er veel 'loos alarm' zou zijn, veel werkmemers zouden ermee als toekomstige arbeidsongeschikten worden aangewezen, terwijl zij dat in werkelijkheid niet zijn.

Dit laatste zou in de praktijk van bijwoorbeeld een BGD meebrengen, dat er kosten en moeite worden gespendeerd aan werknemers die het niet nodig hebben en dat ten koste van degenen die het wel nodig hebben. Daarom is geprobeerd de individuele voorspelling aan te scherpen door een tweede voorspeller toe te voegen. In hoofdstuk 4 was al gebleken, dat het verzuimpercentage ook een goede voorspeller van arbeidsongeschiktheid is. Daarom werden Conditie ${ }_{k}$ en het verzuimpercentage samen in één voorspelling van arbeidsongeschiktheid toegepast. Dit makkte weinig uit in de mogelijkheid om toekomstige arbeidsongeschikten aan te wijzen, maar wel veel in het precies aangeven wie er niet arbeidsongeschikt worden (tabel 5.3). Door de combinatie van Conditie en $_{\mathbf{k}}$ het verzuimpercentage is een veel bruikbaarder voorspelling ontstaan, waardoor met behoorlijke waarschijnlijkheid is aan te geven wie wel en wie niet arbeidsongeschikt zullen worden in de komende jaren. Uit de vergelijking van tabel 5.3 met tabel 4.4 blijkt verder, dat de voorspellingsmogelijkheid van arbeidsongeschiktheid met de korte VAG en het verzuimpercentage zeker zo goed is als die met de lange VAG met het verzuimpercentage. Daarbij is de validiteit (sensitiviteit en specificiteit) van de voorspelling gelijk aan die met de lange VAG. Dit leidt tot de volgende conclusie: moet arbeidsongeschiktheid voorspeld worden, dan is de korte versie van de VAG even goed te gebruiken als de lange versie. 


\section{Validiteit van de korte VAG}

Hiervoor hebben we gezien dat de korte VAG als geheel een minder goede indi-: viduele voorspeller is van arbeidsongeschiktheid dan de index Conditie $e_{k}$ die er deel van is (het andere deel, nl. Werksituatie ${ }_{\mathrm{k}}$ voorspelt niet goed). We kunnen er verder van uitgaan (paragraaf 1.1) dat de praktische voorspelling en de predictieve validiteit van de VAG twee kanten van dezelfde medaille zijn, en kunnen daarom concluderen dat de voorspellingsmogelijkheden bij arbeidsongeschiktheid van de korte versie van de VAG pleiten voor de validiteit ervan.

\subsection{Voorspelling van vervroegd uittreden}

\subsubsection{Verschillen VAG tussen we1- en niet-VUT}

Laten we eerst nagaan of er wel verschillen zijn tussen de wel- en niet-vervroegd uitgetreden werknemers. Om redenen van vergelijkbaarheid met paragraaf 4.2.1 wordt deze vergelijking beperkt tot de mannelijke werknemers van 58 jaar en ouder. Tabel 5.4 geeft de cijfers.

De index Conditie ${ }_{k}$ geeft in drie van de vijf groepen (d.w.z. de grootste groepen) een significant verschil, de index Werksituatie ${ }_{k}$ in geen enkele groep. Als we VUT willen voorspellen, dan blijft alleen Conditie ${ }_{k}$ over. We moeten echter goed op de richting van het verschil letten, want (net als in paragraaf 4.2 .1 ) heeft de toekomstige VUT-groep minder problemen dan de niet-VUT-groep. 


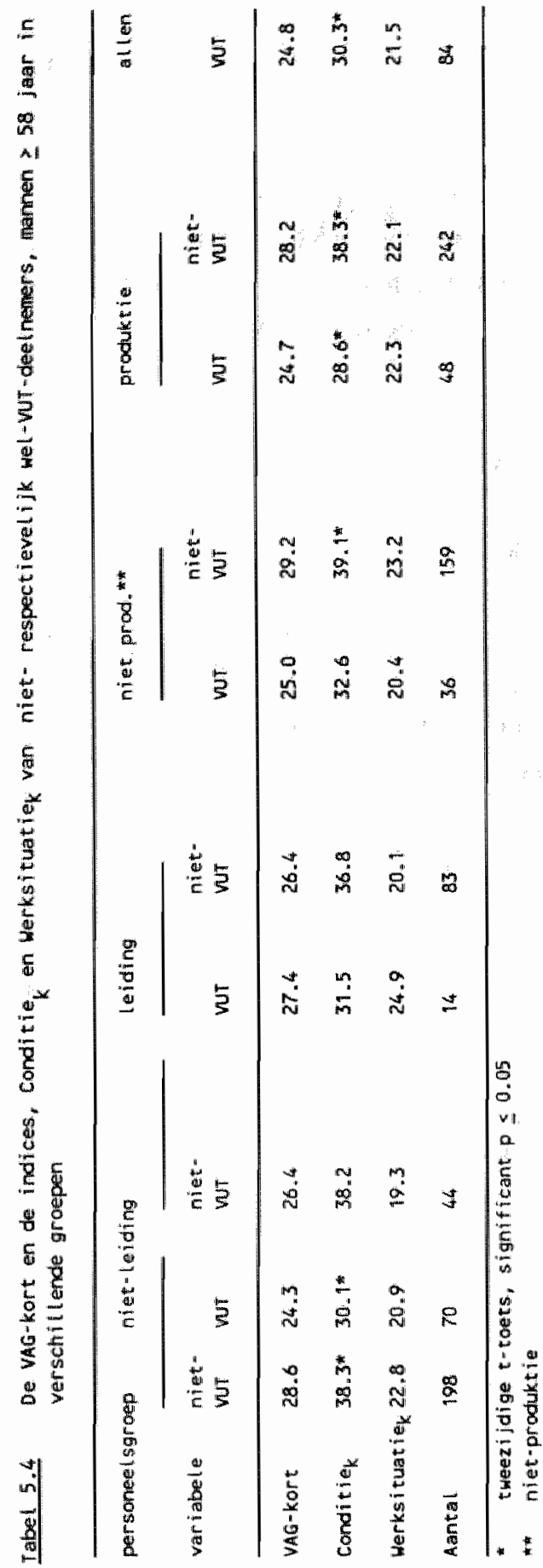


Hoeveel meer kans heeft een werknemer met een hoge score op later vervroegd uittreden, vergeleken met iemand met een lage score? Dat wordt uitgedrukt in de IDR's van tabel 5.5 .

Tabel 5.5. Incidentiedichtheidsratio's (IDR"s) van VAG-kort, Conditie en Werksituatie $\mathrm{k}_{\mathrm{k}}$ bij vervroegd uittreden (mannelijke werknemers, 58+ jaar).

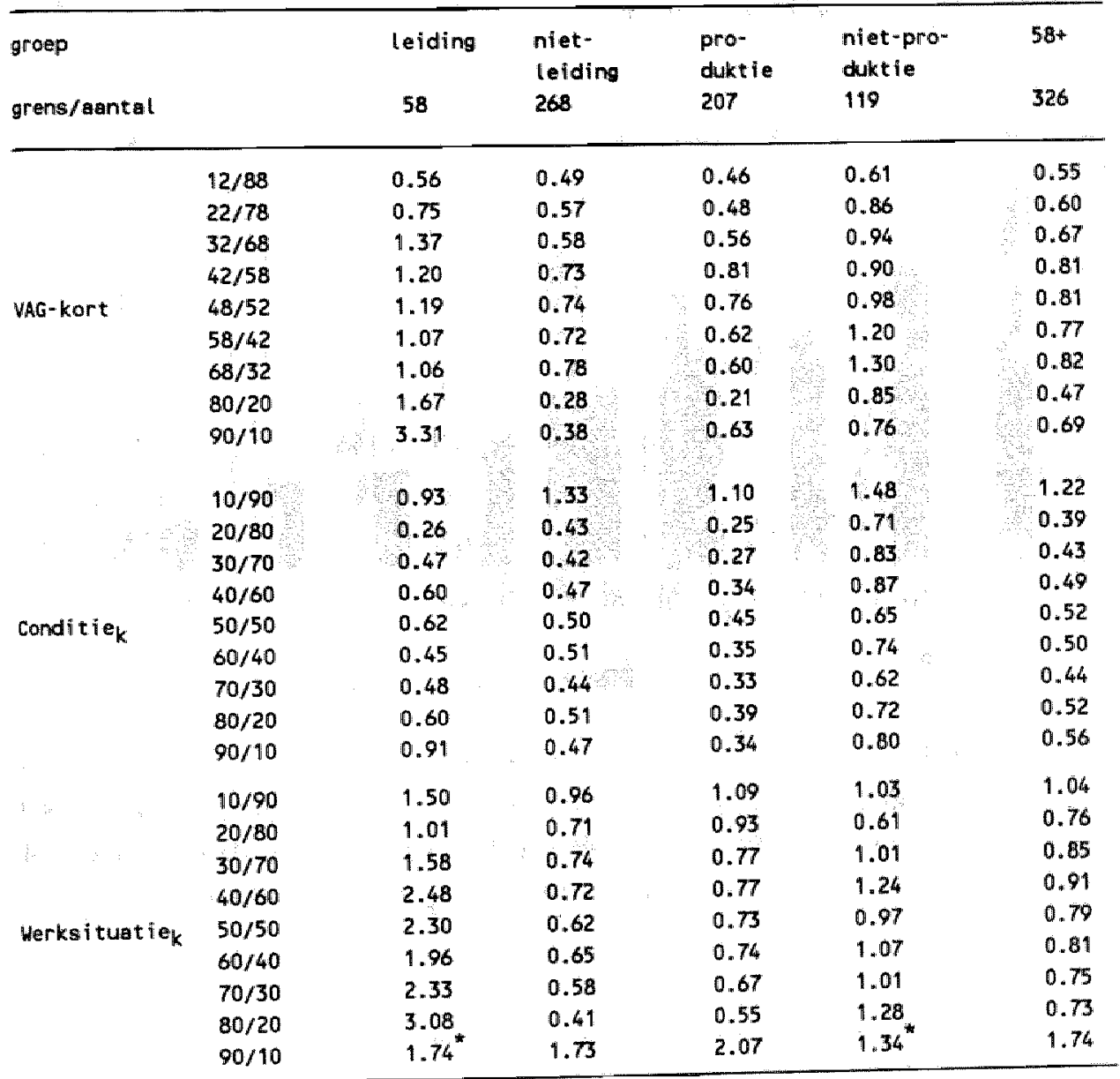

* = geschat 
In paragraaf 5.2.1 werd al opgemerkt, dat de VUT-groep lagere scores had dan de niet-VUT-groep. Hier in tabel $5.5 \mathrm{komt}$ dat tot uiting in lagere kansen, IDR's díe overwegend kleiner dan eén zijn. Verder is ook duidelijk dat Conditie ${ }_{k}$ lagere waarden heeft dan Werskituatie ${ }_{k}$ zodat $_{\text {Conditie }}$ hier de beste voorspeller is. Bijlage 11 en figuur 5.3 gaan over de validiteit (in termen van sensitiviteit en sensitiviteit) van de IDR's van Conditie $_{k}$ uit tabel 5.5 .

Eiguur 5.3 sensitivitelt en specificlteit van conditie ${ }_{k}$ bij vervroegd uittreden, mannel ijke werknemers $58+$ jaar

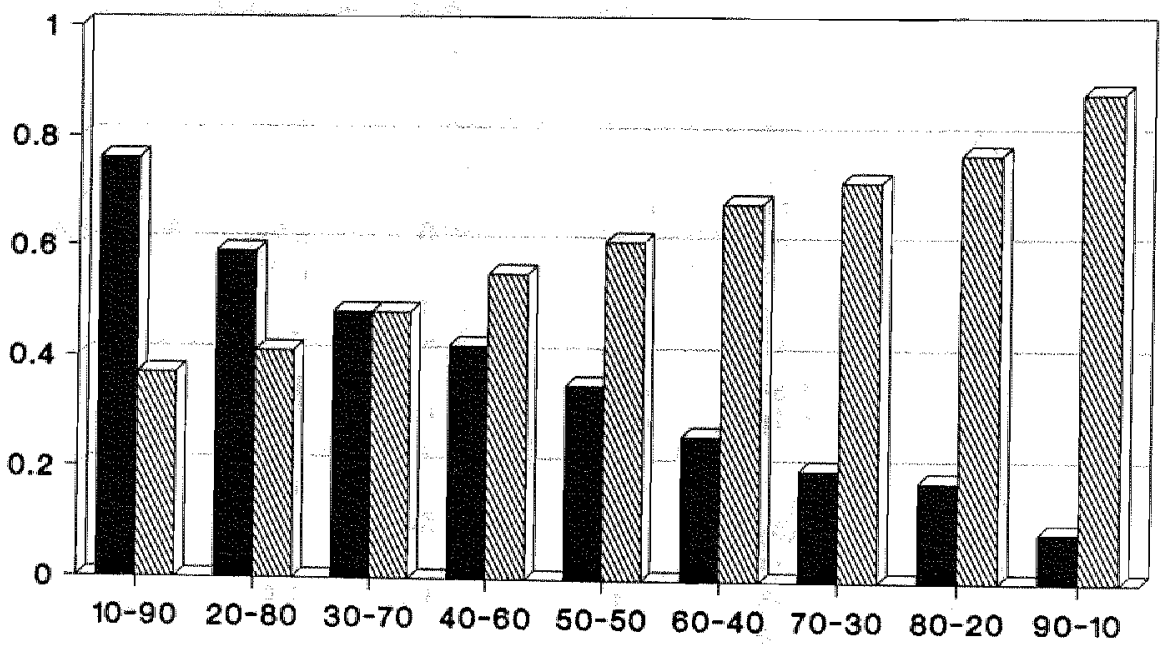

grenswaarde

\section{Sensitiviteit Specificiteit}

Het patroon dat eerder (figuur 5.1) bij arbeidsongeschiktheid te zien was, keert hier terug. Vangen we met Conditie $_{k}$ veel toekomstige VUT-ters, dan is er veel bijvangst van latere niet-VUT en andersom. Daarom moet worden nagegaan of voorspelling met een extra variabele naast Conditie $\mathrm{k}_{\mathrm{k}}$ de voorspelling verbetert.

\subsubsection{VUT: voorspelling uit korte VAG en verzuimgegevens}

Eerder (paragraaf 4.2.3) bleek dat het verzuimpercentage een voorspeller van verwroegd uittreden is. Daarom willen we hier nagaan wat voor voorspellingsmogelijkheid Conditie $_{k}$ en het verzuimpercentage samen geven, als we net als in 
paragraaf 4.2 .4 bij beide variabelen de onderste $80 \%$ met de bovenste $20 \%$ contrasteren.

Iabel 5.6 Hargenomen en voorspelde odds bij vervroegd uittreden, tegelijk Conditie $e_{k}$ en Werksituatie $k$, mannelijke werknemers $58+$ jaar $(n=325$ )

\begin{tabular}{cccccc}
\hline & & \multicolumn{2}{c}{ odds } & & \\
\cline { 3 - 6 } Conditie & verzuim- & $\begin{array}{l}\text { waarge- } \\
\text { nomen }\end{array}$ & $\begin{array}{l}\text { voor- } \\
\text { speld }\end{array}$ & $\begin{array}{l}\text { sensiti- } \\
\text { viteit** }\end{array}$ & $\begin{array}{l}\text { specifi- } \\
\text { citeit** }\end{array}$ \\
\hline$L^{*}$ & $L$ & 0.43 & 0.43 & 0.16 & 0.60 \\
$L$ & $H$ & 0.09 & 0.10 & 0.13 & 0.74 \\
$H$ & $L$ & 0.28 & 0.29 & 0.03 & 0.89 \\
$H$ & $H$ & 0.08 & 0.07 & & \\
\hline
\end{tabular}

* $\mathrm{L}=\mathrm{laag}$, onderste $80 \%$,

** $\quad H=$ haog, bovenste $20 \%$; zie bijllage 5 voor de lligging ven de grenzen

De voorspelde odds liggen dicht in de buurt van de waargenomen odds, zodat het model past, met andere woorden: het is een goed idee om beide gegevens (Conditie $_{k}$ en $\mathrm{V} \%$ ) tegelijk als voorspeller te nemen. De hoogste odds zijn te zien bij de combinatie LL (dus: Conditie $k_{k}$ en verzuimpercentage laagste $80 \%$ versus hoogste $20 \%$ van de werknemers) en ook nog enigszins bij $\mathrm{HL}$.

Om een vergelijking met de IDR's te maken: de odds ratio, de kansverhouding van lage Conditie $e_{k}$ en verzuimpercentage vergeleken met beide hoog is ongeveer vijf $(=0.43: 0.08)$. Dit lijkt een hoge waarde, maar de praktische bruikbararheid ervan hangt af van de precisie (sensitiviteit en specificiteit) van de voorspelling. De juistheid van deze voorspellingen komt eveneens aan de orde in tabel 5.6; figurur 5.4 hieronder geeft dit grafisch weer. 
Eigur 5 , sensitiviteit en specificiteit bij voorspelling van verwroegd uittreden uit tegelijk conditie en verzuimpercentage (mannelijke werknemers $58+$ jaar, vergel $j \mathrm{jk}$ tabel 5.6 )

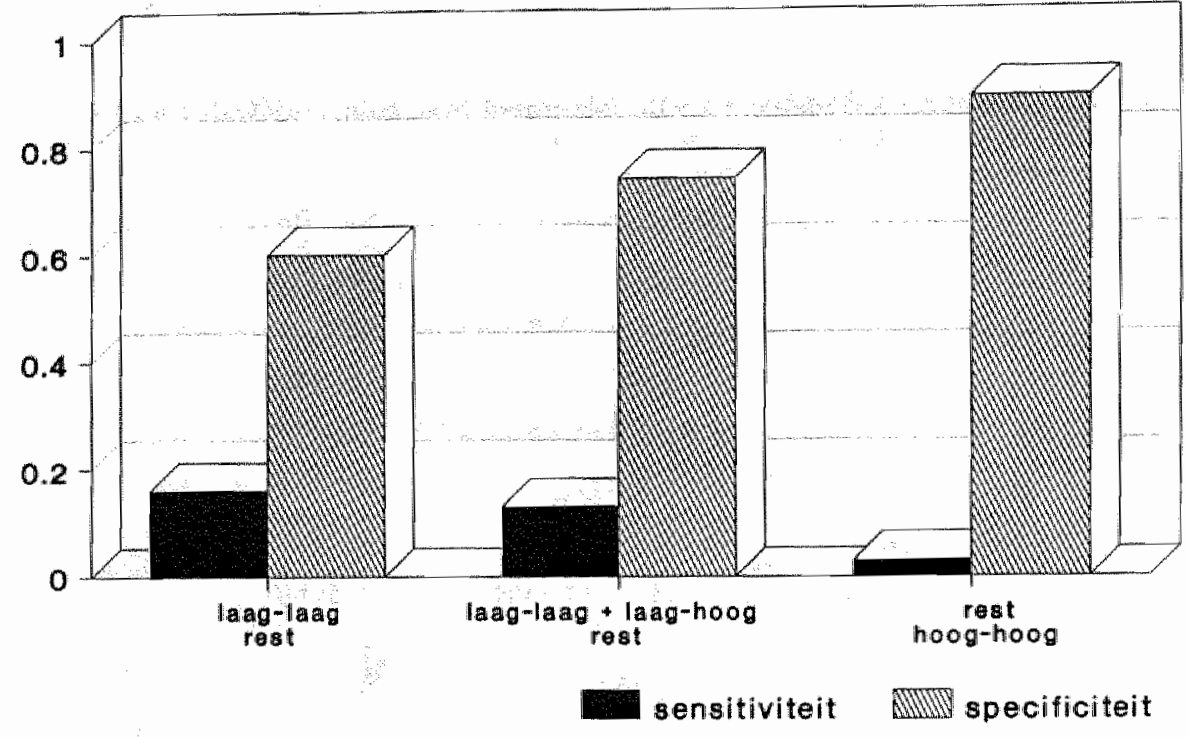

Het aantal VUT-gangers dat voorspeld wordt is maar een klein deel van het werkelijke aantal, de sensitiviteit is dus laag. Het aantal niet-VUT-ters dat voorspeld wordt (de specificiteit) loopt van 0.60 tot 0.89 en is dus veel beter dan de sensitiviteit. Beide gegevens bij elkaar maken toch de individuele voorspelling van VUT een tamelijk lastige zaak.

\subsubsection{VUT en de korte VAG: discussie}

\section{Overeenstemming met de literatuur}

Als de literatuur een beschrijving geeft van de werknemer die met de VUT gaat, dan wordt die laatste afgeschilderd als een vermoeid, dan wel versleten mens. De belangrijkste conclusie die hierover uit de resultaten van dit onderzoek getrokken kan worden is, dat de literatuur van het vervroegd uittreden op dit punt minstens eenzijdig is; de VUT-groep in het onderhavige materiaal bleek weinig klachten over gezondheid en inspanning te hebben en een laag verzuim te vertonen. Deze resultaten pleiten eveneens tegen de "concurrentiehypohese" uit de lite- 
ratuur die stelt dat VUT en arbeidsongeschiktheid allebei oplossingen zijn voor arbeids- en gezondheidsproblemen. Vergelijk paragraf 4.2 .5 : de VUT-groep is betrekkelijk probleemloos, VUT- en arbeidsongeschiktheidsgroepen blijken dus kwallitatief te verschillen, en van concurrentie tussen VUT en arbeidsongeschiktheidsregelingen is daarom geen sprake. Er zou in nader onderzoek nagegaan moeten worden hoe goed of slecht in het algemeen de gezondheid van de werknemer is die met de VUT gaat.

\section{Voorspelbaarheld van toetreding tot de VUT}

De toekomstige VUT-groep heeft minder problemen op de korte VAG dan de miet-VUT-groep (zie ook paragraaf 4.2.5). In de meeste groepen geldt dat zowel wat betreft de gezondheid en inspanning (Conditie $k$ ) als wat betreft de verdlere werkomstandigheden (Werksituatie ${ }_{k}$ ). Over groepen gezien is er dus een duidelijk resultaat; geldt dat ook voor de individuele voorspelling? Van de twee genoemde maten blijkt Werksituatie ${ }_{k}$ een slechtere individuele voorspeller te zijn van vervroegd uittreden dan Conditie $\mathrm{k}$. Maar ook met deze laatste variabele is een probleem, dat het gemakkelijker is, de niet-VUT-dan de VUT-groep aan te wijzen. Wordt om die reden ook het verzumpercentage in de voorspelling betrokken, dan wordt de voorspelling nauwelijks sterker (zie tabel 5.6).

Liggen deze resultaten anders dan bij de lange versile van de VAG? Binnen deze twee vragenlijsten stonden de index Conditie ${ }_{l}$ (tabel 4.7) en Conditie ${ }_{k}$ (tabel 5.4) op de voorgrond, waarbij de VUT-groep lagere scores heeft (minder problemen) dan de niet-VUT-groep. Conditie, gaf bij de VUT kansverhoudingen (IDR;s) van 0.34 tot 0.53 en Conditie ${ }_{k}$ van 0,39 tot 1.22 , dus iets slechter. Verder bleek (figuur 4.3) dat de geldigheid van deze voorspelling (sensitiviteit en specificiteit bij Conditie, te laag is voor praktische doeleinden; voor Conditie $k_{k}$ geldt hetzelf de (figuur 5.3, bijlage $\mathbb{1 1}$ ). Deze laatste is alles bij elkaar niet beter of slechter dan Conditie, als voorspeller van de VUT. Met beide indices kunnen verschillen aangetoond worden tussen de WUT-groep (weinig problemen) en niet-VUTgroep (meer problemen), maar een sterke individuele voorspelling van latere VUT is met geen wan beide variabelen mogelijk. 


\section{Validiteit van de korte VAG}

De discussie m.b.t. de voorspellingsmogelijkheden van de VUT met de VAG (hierboven) haalt een aantal uitkomsten aan die ook als argument voor de validiteit van de VAG kunnen gelden. De korte VAG zowel als zijn onderdelen (Conditie $_{\mathrm{k}}$ en Werksituatie $\mathrm{k}_{\mathrm{k}}$ ) geeft overal verschillen tussen wel- en niet-VUT-groep te zien. De individuele voorspelling van de VUT mag dan niet sterk zijn, de consistentie waarmee groepsverschillen optreden vormt een aanwijzing voor de validiteit wan de VAG en voor zijn beide onderdelen.

\subsection{Voorspelling wan ontslagname}

\subsubsection{Verschillen tussen wel- en niet-ontslagname}

Er zijn twaalf groepen werknemers onderscheiden waarbinnen naar voorspellingsmogelijkheden van ontslagname gezocht wordt. De gemiddelden van de VAG kort, Conditie ${ }_{k}$ en Werksituatie ${ }_{k}$ worden vermeld in tabel 5.7. 


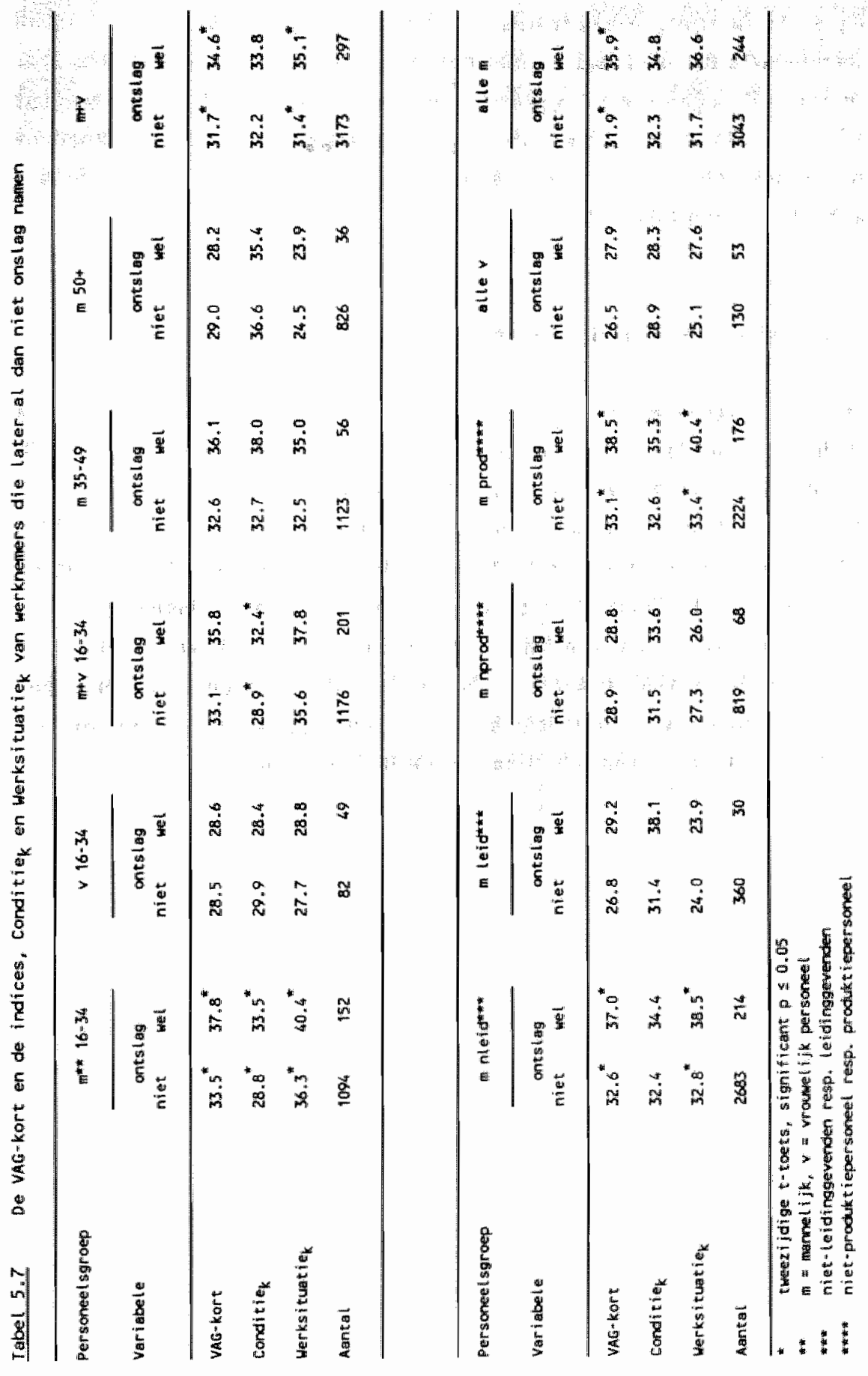


Conditie $_{k}$ geeft in twee, Werksituatie ${ }_{k}$ in vier groepen een significant verschil tussen werknemers die later wel en niet ontslag namen. In vele subgroepen is er dus geen verschil tussen die twee groepen te zien; het naar verhouding grootste verschil is te zien in de index Werksituatie ${ }_{k}$ bij de groep mannelijke werknemers in de produktieafdellingen. Dit zal moeten worden weerspiegeld in de kansverhoudingen (IDR's) van tabel 5.8 .

\subsubsection{Ontslagname: voorspellend vermogen korte VAG}

Het voorspellend vermogen is hier berekend als de kans dat een werknemer in een bepaalde tijd ontslag neemt, als hij een bepaalde score op de korte VAG, Conditie $_{k}$ of Werksituatie $_{k}$ heeft ten opzichte van iemand met een lagere score (zie voor een nauwkeuriger omschrijving paragraaf 3.11). Enkelle IDR's in tabel 5.8 moesten worden geschat; dit heeft de wolgende reden (zie de definitie van de IDR in paragraaf 3.11). Soms bleek er geen enkel geval van ontslagname te zijn in de laagscorende groep. Dit zou bij de berekening van de IDR een deling door nul inhouden en die is, zoals bekend, verboden. In zulke gevallen is er van uitgegaan dat er één ontslaggeval in de lage groep was, en is de berekening vervolgens normaal uitgevoerd om tot een schatting van de IDR te komen. 
Iobel 5.8 Incidentiedichtheidsratio"s (IDR/s) van vma-kort, conditie en werksituatlie bij onts lagname (mannelijike en vrouweltijke werknemers)

\begin{tabular}{|c|c|c|c|c|c|c|c|}
\hline \multicolumn{2}{|c|}{$\begin{array}{l}\text { giroep* } \\
\text { grens/aantal }\end{array}$} & $\begin{array}{c}16-34 \\
1246\end{array}$ & $\begin{array}{c}16 \cdot 34 \\
131\end{array}$ & $\begin{array}{c}m+1 / 6-34 \\
137\end{array}$ & \multirow[t]{2}{*}{$\begin{array}{c}35-49 \\
1179\end{array}$} & \multirow[t]{2}{*}{$\begin{array}{l}50+ \\
862\end{array}$} & \multirow[t]{2}{*}{$\begin{array}{l}m+v \\
3470\end{array}$} \\
\hline 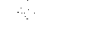 & & a & & & & & \\
\hline . & $12 / 88$ & 1.49 & 1.54 & 1.32 & 0.95 & 1.26 & 1.39 \\
\hline & $22 / 78$ & 1.70 & 1.47 & 1.40 & 1.38 & 1.58 & 1.53 \\
\hline & $32 / 68$ & 1.72 & 0.88 & 1.22 & 1.08 & 1.43 & 1.35 \\
\hline VAG & $42 / 58$ & 1.59 & 1.12 & 1.24 & 1.39 & 1.57 & 1.43 \\
\hline \multirow[t]{7}{*}{ kort } & $48 / 52$ & 1.44 & 1.16 & 1.17 & 1.59 & 1.12 & 1.34 \\
\hline & $58 / 42$ & 1.21 & 1.34 & 1.09 & 1.44 & 0.81 & 1.23 \\
\hline & $68 / 32$ & 9.44 & 1.40 & 1.27 & 1.62 & 0.42 & 1.33 \\
\hline & $80 / 20$ & 11.47 & 2.25 & 1.39 & 1.80 & 0.18 & 1.42 \\
\hline & $90 / 10$ & 1.43 & 1.08 & 1.23 & 2.43 & 0.48 & 1.52 \\
\hline & $10 / 90$ & 1.12 & $0 . .98$ & 1.14 & 3.92 & 1.19 & 1.20 \\
\hline & $20 / 80$ & 1.52 & 0.97 & 1.36 & 0.91 & 1.08 & 1.20 \\
\hline Condi - & $30 / 70$ & 1.57 & 0.95 & 1.42 & 0.77 & 0.58 & 1.05 \\
\hline \multirow[t]{8}{*}{ tiek } & $40 / 60$ & 11.80 & 0.64 & 1.42 & 1.32 & $0.6 B$ & 1.16 \\
\hline & $50 / 50$ & 1.65 & 0.65 & 1.38 & 1.36 & 0.65 & 1.10 \\
\hline & $60 / 40$ & 1.68 & 0.69 & 1.42 & 1.90 & 0.74 & 1.20 \\
\hline & $70 / 30$ & 1.50 & 0.87 & 11.36 & 1.15 & 0.78 & 1.04 \\
\hline & $80 / 20$ & 1.28 & 1.08 & 1.28 & 1.47 & 0.87 & 1.00 \\
\hline & $90 / 10$ & 1.47 & 2.47 & 1.59 & 2.59 & 1.76 & 1.33 \\
\hline & $10 / 90$ & 139 & 3.98 & 1.56 & 1.05 & 1.61 & 1.64 \\
\hline & $20 / 80$ & 1.27 & 1.33 & 1.09 & 1.77 & 1.31 & 1.44 \\
\hline Werk- & $30 / 70$ & 1.51 & 1.25 & 1.24 & 1,63 & 1.31 & 1.56 \\
\hline situ- & $40 / 60$ & 1.56 & 1.69 & 1.30 & 1.29 & 0.98 & 1.51 \\
\hline \multirow[t]{5}{*}{$\operatorname{atie_{k}}$} & $50 / 50$ & 1.41 & 1.66 & 4.20 & $1: 31$ & 0.83 & 1.42 \\
\hline & $60 / 40$ & 1.28 & 1.68 & 9.13 & 1.44 & 0.62 & 1.37 \\
\hline & $70 / 30$ & 1.29 & 1.64 & 11.15 & 1.88 & 0.51 & 1.46 \\
\hline & $80 / 20$ & 1.57 & 1.62 & 1.33 & 1.71 & 0.30 & 1.59 \\
\hline & $90 / 10$ & 1.43 & औ. 13 & 1.21 & 2.21 & $1.00^{* * *}$ & 1.62 \\
\hline
\end{tabular}

* in = mannelijke, $v=$ wrouwel ijke; $t=$ total werknemers

* geschat 


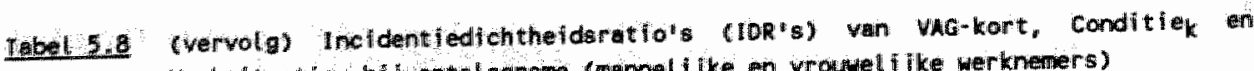
Wericsi tuatie bij onts lagname (mannel ijke en wrouvel ijke werknemers)

\begin{tabular}{|c|c|c|c|c|c|c|c|}
\hline \multicolumn{2}{|c|}{ groep* } & $\begin{array}{l}\text { m ntefod } \\
2897\end{array}$ & \multirow{2}{*}{ 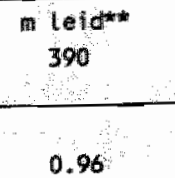 } & \multirow{2}{*}{$\begin{array}{c}\operatorname{mpr}_{887} \\
0.97\end{array}$} & \multirow{2}{*}{$\begin{array}{l}\frac{m_{\text {prod }}}{2400} \\
2.02\end{array}$} & \multirow{2}{*}{$\begin{array}{l}\begin{array}{l}\text { alle } \\
183\end{array} \\
1.58\end{array}$} & \multirow{2}{*}{$\begin{array}{l}\text { alle } \mathrm{m} \\
3287 \\
\\
\end{array}$} \\
\hline : & $12 / 80$ & 1.65 & & & & & \\
\hline 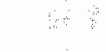 & $22 / 78$ & 1.86 & 1.43 & 1.31 & 2.14 & 1.46 & $\begin{array}{l}1.48 \\
1.77\end{array}$ \\
\hline 8 & $32 / 68$ & 1.66 & 9.72 & 1.12 & 2.07 & 1.01 & 1.66 \\
\hline VAG & $42 / 58$ & 1.68 & 2.13 & 1.30 & 1.99 & 1.15 & 1.72 \\
\hline \multirow[t]{2}{*}{ kort } & $48 / 32$ & 1.53 & 1.95 & 1.06 & 1.87 & 4.13 & 1.57 \\
\hline & $58 / 42$ & 1.35 & 1.23 & 0.72 & 1.65 & 1.51 & 1.33 \\
\hline \multirow[t]{2}{*}{ : } & $68 / 32$ & 1.52 & 0.92 & 0.65 & 1.81 & 1.62 & 1.43 \\
\hline & $80 / 20$ & 1.60 & 0.52 & 0.65 & 1.80 & 2.98 & 1.48 \\
\hline & $90 / 10$ & 1.81 & 0.68 & 0.54 & 2.13 & 1.59 & 1.72 \\
\hline & $20 / 80$ & $\begin{array}{l}1.08 \\
1.22\end{array}$ & $\begin{array}{l}3.16^{* 6} \\
1.56\end{array}$ & $\begin{array}{l}3.17 \\
2.21\end{array}$ & 1.03 & 1.36 & 1.26 \\
\hline Condi i - & $30 / 70$ & $\begin{array}{l}1.26 \\
1.04\end{array}$ & 1.35 & 1.50 & 0.95 & 1.10 & 1.08 \\
\hline \multirow[t]{8}{*}{ tiek } & $40 / 60$ & 1.31 & 1.57 & 1.64 & 1.24 & 0.72 & 1.34 \\
\hline & $50 / 50$ & 1.17 & 1.61 & 1.48 & 1.14 & 0.76 & 1.22 \\
\hline & $60 / 40$ & 1.30 & 1.45 & 1.46 & 1.27 & 0.91 & 1.32 \\
\hline & $70 / 30$ & 1.04 & 1.31 & 1.01 & 1.09 & 1.29 & 1.07 \\
\hline & $80 / 20$ & 0.97 & 1.45 & 0.80 & 1.12 & 1.23 & 1.03 \\
\hline & $90 / 10$ & 1.29 & 1.99 & 0.64 & 1.76 & 1.66 & 1.39 \\
\hline & $10 / 90$ & 1.83 & 1.07 & 1.05 & 2.45 & 2.34 & 1.60 \\
\hline & $20 / 80$ & 1.75 & $1.34^{\mathrm{h}}$ & 1.09 & 2.27 & 1.43 & 1.65 \\
\hline werk & $30 / 70$ & 1.91 & 1.44 & 1.17 & 2.40 & 1.50 & 1.80 \\
\hline situ- & $40 / 60$ & 1.82 & 1.14 & 1.04 & 2.16 & 1.62 & 1.68 \\
\hline \multirow[t]{5}{*}{ atiek } & $50 / 50$ & 1.80 & 0.62 & 0.76 & 2.13 & 1.67 & 1.56 \\
\hline & $60 / 40$ & 1.68 & 0.51 & 0.73 & 1.90 & 1.68 & 1.48 \\
\hline & $70 / 30$ & 1.71 & 0.86 & 0.65 & 2.03 & 1.60 & 1.60 \\
\hline & $80 / 20$ & 1.90 & 0.57 & 0.62 & 2.20 & 1.81 & 1.79 \\
\hline & $90 / 10^{* * * *}$ & 1.91 & $3.45 * k$ & 0.32 & 2.25 & 1.66 & 1.84 \\
\hline
\end{tabular}

* m mannel ijke, $v=$ vrouwelffje, $t=$ total werknemers

* niet-leidinggevenden resp. leidinggevenden

* nilet-produkt lepersonel resp. produkti iepersoneel

**.* geschet

In sommige groepen werknemers neemt de IDR, afhankelijk van waar we de grens wensen te trekken, waarden aan van zowel kleiner als groter dan én (bijv. Conditie $_{k}$ bij mannelijke werknemers $50+$ jaar). $\mathrm{Nu}$ eens is een hoge score, dan weer een lage indicatief voor later ontslag. Aan zo een inconsistente voorspeller 
is moeilijk betekenis te geven want we mogen toch wel eisen, dat zijn waarden of allemaal kleiner of allemaal groter zijn dan eèn. Verder moet een goede voorspeller veel kleiner of veel groter dan eên zijn. De enige voorspeller die tegelijk aan deze twee eisen voldoet (consistent ver van de eenhelidswaarde) is Werksitua$t e_{k}$ in de groep mannelijke produktiewerknemers. Eind vorige paragraaf viel dit ook al op.

We gaan voor deze voorspeller en groep werknemers na, hoe goed de voorspelling is. De nauwkeurigheid van de voorspelling (sensitiviteit en specificiteit) van ontslagname is aangegeven in bijlage 13 en figur 5.5 .

Figuur 5.5. Sensitiviteit en specificiteit van werksituatie bij ontslagname (mannelilke werknemers in produktie-afdel ingen)

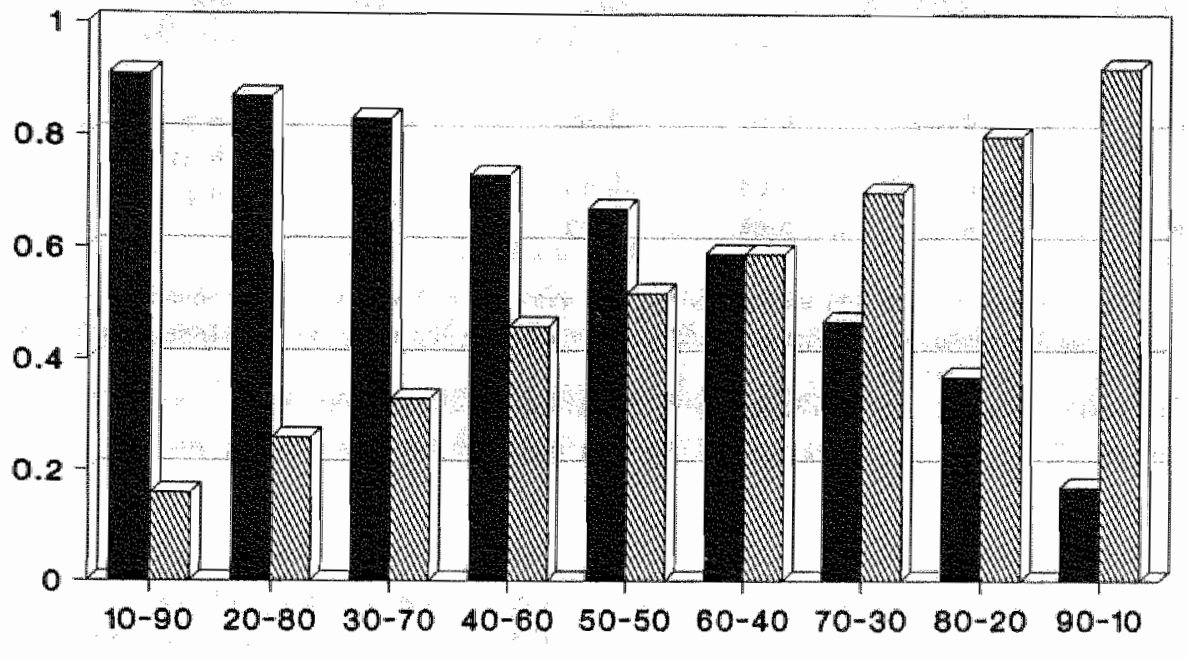

grenswaarde

Sensitiviteit Specificiteit

Als de grens in Werksituatie $\mathrm{k}_{\mathrm{k}}$ laag ligt, is het gemakkelijk alle werknemers met latere ontslagname in de hoog scorende groep te krijgen. De keerzijde hiervan is, dat zo ook veel werknemers van de niet-ontslaggroep in de hoge scores vallen. Net als bij alle eerdere voorspellingen is hier maar éen ding aan te doen, $\mathrm{nl}$. de grenswaarde verhogen. Dan daalt het aantal terecht aangewezen ontslaggevallen wel (de sensitiviteit daalt), maar het aantal juist aangewezen niet-ontslaggevallen (de sensitiviteit) stijgt. 


\subsubsection{Ontslagname: woorspelling uit korte $\mathrm{VAG}$ en verzuímgegevens}

De voorspelling van latere ontslagname uit Werksituatie zou kunnen worden verbeterd door ook een verzuimgegeven in de voorspelling op te nemen. In paragraaf 4.3 .1 bleek, dat de verzuimfrequentie meer met latere ontslagname te maken heeft dan het verzuimpercentage. We kiezen daarom ook hier de verzuim-

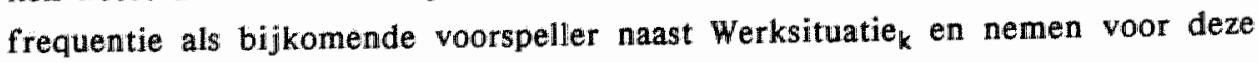
groep optimale grenswaarden. Dit leidt tot de resultaten van tabel 5.9 .

Tabel 5.9 Wargenomen en voorspelde odds bij ontslagneme, tegelijk Werksituetiek en Verzuififrequentile, mannel $f$ jke werknemers in de produktieafdelingen ( $n=2400$ ).

\begin{tabular}{|c|c|c|c|c|c|}
\hline \multirow[b]{2}{*}{$\begin{array}{l}\text { Werksi- } \\
\text { tuat I ek }\end{array}$} & \multirow[b]{2}{*}{$\begin{array}{l}\text { verzuim- } \\
\text { frequent ie }\end{array}$} & \multicolumn{2}{|c|}{ odds } & \multirow[b]{2}{*}{$\begin{array}{l}\text { sensiti- } \\
\text { viteit t* }\end{array}$} & \multirow[b]{2}{*}{$\begin{array}{l}\text { specifi- } \\
\text { citeit }\end{array}$} \\
\hline & & $\begin{array}{l}\text { Wearge- } \\
\text { nonem }\end{array}$ & $\begin{array}{l}\text { voor- } \\
\text { speld }\end{array}$ & & \\
\hline$L^{*}$ & L & 0.05 & 0.04 & 0.83 & 0.23 \\
\hline $\mathbf{L}$ & $H$ & 0.03 & 0.04 & 0.71 & 0.47 \\
\hline$H$ & $L$ & 0.09 & 0.10 & 0.45 & 0.67 \\
\hline H & $H$ & 0.09 & 0.09 & & \\
\hline
\end{tabular}

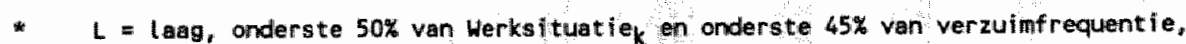
$H=$ hoog, bovenste $50 \%$ en bovenste $55 \%$ van verzutmfrequentie; zie bijlage 5 voor de \#igging van de grenizen

* Bij respectievelijk LL. tegenover rest, $L L$ en $L H$ tegenover rest en $L L$, $L H$ en $H L$ tegenover HHH.

Net als bij arbeidsongeschiktheid en VUT wijken de voorspellingen nauwelijks af van de wargenomen odds. Het is daarom toegestaan twee voorspellers tegelijk nemen. Het is duidelijk dat de kans op ontslagname afhangt van de score die een werknemer op Werksituatie ${ }_{k}$ en verzuimfrequentie heeft: $z$ jin beide hoog of is

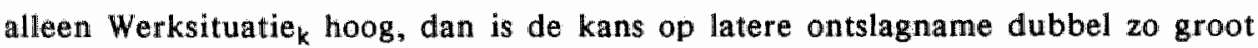

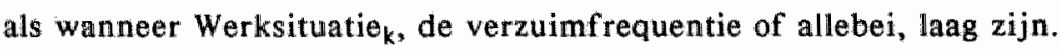

De precisie van deze voorspelling van ontslagname uit tegelijk Werksituatie $\mathrm{k}_{\mathrm{k}}$ en verzuimfrequentie werd al aangegeven in tabel 5.9. Grafisch is een en ander voor de groep mannelijke werknemers in de produktie weergegeven in figuur 5.6. 
Flgur 5.6 sensitiviteit en specificiteit bif voorspelling van ontslagnane uif tegelijk Werksituatie ${ }_{k}$ en verzuimfrequentive (mannelijke werkneners in de praduktie, vergelijk tabel 5.9 )

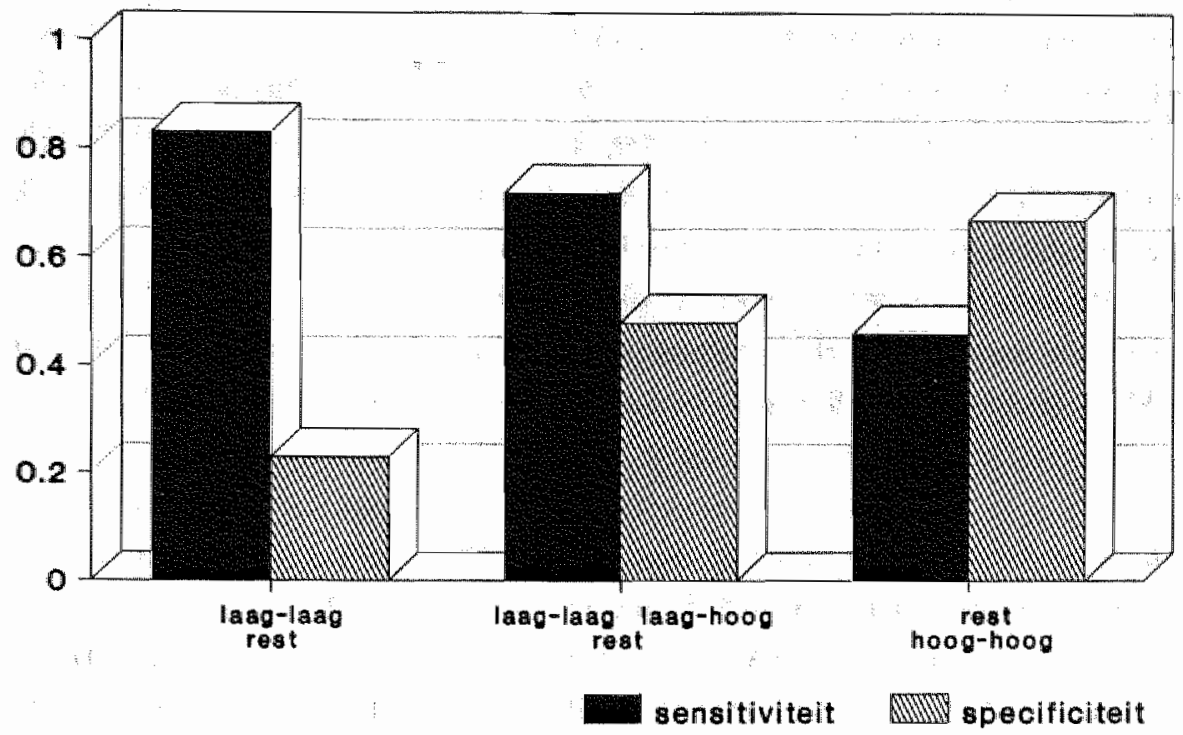

Vergeleken met figuur 5.5 zijn de cijfers er nauwelijks op vooruitgegaan. Toevoegen van de verzuimfrequentie aan de voorspelling van ontslagname verbetert de nauwkeurigheid van voorspelling niet noemenswaard.

\subsubsection{Ontslagname en korte VAG: discussie}

\section{Overeenstemming met de literatuur}

Er werd op grond van de literatuur verwacht (paragraaf 2.5.3) dat de ontslaggroep op alle variabelen meer problemen (hogere scores) en hoger verzuim zouden hebben dan de niet-ontslaggroep. Dit werd (net als in paragraaf 4.3 .3 m.b.t. de lange VAG) niet over de hele linie bevestigd, zodat de gegrondheid van die verwachting twijfelachtig is. We kunnen net als bij de resultaten van de lange VAG veronderstellen, dat de ontslagname maar voor een deel gedetermineerd wordt door de actuele werksituatie. Vermoedelijk speelt de situatie buiten deze werksituatie een belangrijke rol in het proces dat tot ontslagname leidt. 


\section{Voorspelbaarheld van on tslagname}

De uitkomst wat betreft de ontslagname is, dat hier wel een zekere individuele voorspelling mogelijk is maar dat, ook als de uitspraken van de werknemers over hun werksituatie gecombineerd worden met hun verzuimf requentie, de voorspelling nog steeds niet sterk is. Dat kan betekenen, zoals all hierboven en in paragraaf 4.3 .5 werd geopperd, dat de ontslagname niet zozeer met de werksituatie samenhangt, mar met factoren buiten de werksituatie. Vermoedelijk heeft de ontslagname deels te maken met zaken als trouwen, kinderen krijgen en onverwachte kansen op de arbeidsmarkt. Voor de modale werknemer (het voorbeeld dat we namen van mannelijke werknemers in de produktie) is ongenoegen met de werksituatie maar een klein deel van de verklaring van de latere ontslagname.

We zullen tenslotte nagaan of er in de korte en de lange VAG verschillen zijn ten aanzien van de voorspelling van latere ontslagname. Beide versies laten maar in een deel wan alle groepen werknemers verschillen tussen de wel- en niet-ontslaggroep zien (tabel 4.1 en 5.7). Verder bleek de voorspellende kracht van beide versies (de IDR's in tabel 4.12 en 5.8 ) niet groot te zijn. Het is net als bij de VUT wel mogelijk om verschillen te laten zien op de lange en de korte versie van de VAG tussen de wel-en de niet-ontslaggroep. Hierin komen de indices Werksituatie $_{\mathfrak{l}}$ en Werksituatie $_{k}$ als onderdeel van de beide vragenlijsten overeen. Maar goede voorspellingen wie er individueel wel en niet ontslag zullen nemen zijn met geen van beide versies van de VAG mogelijk.

\section{Validiteit wan de korte VAG}

De individuele voorspelling van ontslagname uit de korte VAG is, zoals hiervoor al werd gesteld, niet echt goed mogelijk. Of men de korte VAG als geheel neemt dan wel delen ervan, of men de VAG-gegevens combineert met verzuimgegevens, het helpt weinig om over een afzonderlijke werknemer een uitspraak te doen of hij ontslag zal nemen of niet. Op groepsniveau zijn er wel duidelijke verschillen in de VAG als geheel en de beide delen ervan (Conditie ${ }_{k}$ en Werksituatie $_{k}$ ), want alle drie deze scores zijn in de onstslaggroep meestal hoger dan in de niet-ontslaggroep (tabel 5.7). Als conclusie kunnen we daarom zeggen dat de resultaten wat betreft ontslagname een bescheiden steun vormen voor de predictieve validiteit van de VAG en zijn onderdelen. 
Op groepsniveau kunnen er bij alle drie de vertrekwijzen verschillen optreden tussen de VAG-scores wan de wel- en niet-vertrokkenen. Deze verschillen dragen bij aan de voorspellende validiteit van de VAG. Vergelijken we de individuele voorspellingsmogelijkheid van de drie beschouwde vertrekwijzen, dan blijkt dat vervroegd uittreden beter te voorspellen is dan ontslagname en arbeidsongeschiktheid weer beter dan de twee andere. Dat kan er aan liggen; dat bij ontslagname en VUT de determinanten meer buiten dan binnen de arbeidssituatie liggen (zie ook paragraaf 4.4). Bij ontslagname werd al genoemd huwelijk, geboorte van kinderen en kansen die zich op de arbeidsmarkt voordoen; bij de VUT-beslissing zouden het verwachte inkomen en de actuele inkomenssituatie een belangrijke rol kunnen spelen. Over geen van deze zaken zijn hier gegevens aanwezig; de genoemde vermoedens kunnen niet direct getoetst worden.

We hebben gezien dat arbeidsongeschiktheid en vervroegd uittreden met elkaar te maken hebben. Beide hangen nl. samen met klachten over gezondheid, inspanning en ziektegedrag (samen Conditie ${ }_{k}$ ) en met het verzuimpercentage, maar de samenhangen zijn tegengesteld: arbeidsongeschiktheid is vroeg te herkennen aan veel van deze problemen en veel verzuim, VUT juist an weinig. Hetzelfde wat in hoofdstuk 4 werd gevonden met de lange versie van de VAG vinden we hier met de korte versie. Er blijkt een middengroep te zijn van werknemers die niet arbeidsongeschikt worden en evenmin met de VUT gaan, er is een tweede groep met weinig problemen en verzuim die vervroegd uittreedt en een derde groep met veel problemen en verzuim die vroeg vertrekt door arbeidsongeschiktheid.

Arbeidsongeschiktheid bleek dus op individueel niveau de best voorspelbare vertrekwijze. Deze woorspelling is sterker dan de relatie roken - hartziekten (Karasek e.a., 1987) en tegelijk relatief nauwkeurig. Voorspelling van arbeidsongeschiktheid bleek beter mogelijk dan van VUT of ontslagname. Dat is in zekere zin gelukkig, omdat arbeidsongeschiktheid de meest ongewenste vertrekwijze is en juist hiervoor de duidelijkste vroege signalen aanwezig blijken te zijn. Deze signalen treden al jaren voor de eigenlijke arbeidsongeschiktheild op en geven daardoor de mogelijkheid, in een vroeg stadium preventieve maatregelen te nemen. Er kon aangetoond worden dat de voorspelling aan de hand van de VAG 
korte versie even goed is als die met de lange versie. Dat kan in de praktijk grote winst aan tijd en kosten betekenen, zodat de drempel om aan deze voorspellingen te beginnen, niet al te hoog hoeft te zijn.

In hoofdstuk 4 werd er al op gezen dat de sterke voorspelling van arbeidsongeschiktheid, maar ook de wat zwakkere van VUT en ontslagname (althans op individueel niveau) wijzen op de validiteit van de lange VAG. Nu blijkt dat waar het gaat om voorspellingsmogelijkheden, de resultaten van de korte VAG vergelijkbaar zijn met die van de lange VAG, kunnen we hetzelfde vaststellen wat betreft de korte versie van de VAG.

In de algemene discussie bij het vorige hoofdstuk (paragraaf 4.4) werd al gewezen op de gevolgen van de keuze van de 'grenswaarde" in de voorspellers; waar moet de grens tussen hoog en laag verzuim, tussen hoge en lage scores worden getrokken? Ook werd al verduidelijkt, dat dit een praktische afweging is, die niet op theoretische gronden gemaakt kan worden. Laten we net als in paragraaf 4.1.5. aan de hand van een voorbeeld proberen na te gaan, wat de consequenties van verschillende keuzen zijn.

In figuur 5.2 werd met betrekking tot arbeidsongeschiktheid geillustreerd hoe de sensitiviteit en specificiteit liggen, als Conditie ${ }_{k}$ en verzuimpercentage gevarieërd worden. Bij beide noemen we laag (L) de onderste $80 \%$ en hoog $(\mathrm{H})$ de bovenste $20 \%$ van de werknemers. Voor respectievelijk Conditie ${ }_{k}$ en verzuimpercentage hebben we dan de combinaties LL, LH, HL en $H H$. We kunnen dan de grens leggen op drie plaatsen, ni. bij $\mathrm{LL}$ tegenover alles wat hoger is, bij $\mathrm{LL}$ en $\mathrm{LH}$ samen tegenover de rest en bij de eerste drie combinaties (LL, LH en HL) tegenover HH. Welke invloed dit op de beslissingen met betrekking tot een groep

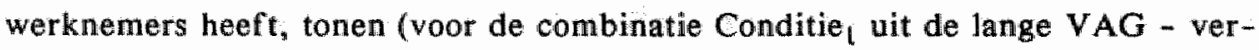
zuimpercentage) de drie tabelletjes binnen tabel 4.6 (paragraaf 4.1.5). Voor de combinatie Conditie ${ }_{k}$ (uit de korte VAG) - verzuimpercentage liggen de uitkomsten principieel hetzelfde, daarom wordt hier van een afzonderlijke tabel voor de korte VAG afgezien. Waar het om gaat, is dat in alle gevallen de keuze van de grens tussen lage en hoge scores (Conditie ${ }_{k}$ ) en hoog en laag verzuimpercentage consequenties heeft voor de praktijk. Legt men die grens laag, dan worden vrijwel alle toekomstige arbeidsongeschikten angewezen, maar met hen tegelijk de- 
gene die wel hoog scoren, maar die niet arbeidsongeschikt zullen worden. Aan de laatste groep wordt dan moeite en geld besteed die beter ergens anders aan gespendeerd hadden kunnen worden. In het omgekeerde geval, dus als de grens hoog gelegd wordt, is de kans dat men zijn kruit verschiet op de verkeerde groep veel kleiner, maar daar staat tegenover dat dan veel toekomstige arbeidsongeschikten geen aandacht krijgen.

Hoe zwaar deze verschillende consequenties in de praktijk moeten wegen, is niet uit te maken, los van de praktijksituatie. Daar en niet van buitenaf, moet uitgemaakt worden waar de grens tussen hoog en laag gelegd moet worden, rekening houdend met de praktische gevolgen van a) loos alarm en b) ten onrechte geen alarm. Deze afweging dient te leiden tot een optimale grens en een optimale voorspelling van het vertrek van werknemers. Belangrijker dan het bepalen van deze grens is echter de wil, onnodige uitwal uit het werk te voorkomen door werknemers met toenemende problemen op te sporen en hun arbeidssituatie te verbeteren.

Als slotconclusie kan over de korte versie van de VAG het volgende gelden. De korte VAG kan op valide wijze groepsversehillen aangeven tussen toekomstige blijvende en vertrekkende werknemers (al of niet arbeidsongeschikt, al of niet VUT, al of niet ontslagname). De individuele voorspellingsmogelijkheden nemen echter af in de volgorde arbeidsongeschiktheid (goed voorspelbaar), VUT (minder goed voorspelbaar) en ontslagname (matig voorspelbaar). Wat betreft de arbeidsongeschiktheid is de voorspellende waarde van de korte VAG even groot, zo niet groter, dan die van de lange VAG. In de praktijk kunnen beide versies van de VAG daarom gebruikt worden voor het voorspellen van vertrek $(i, h, b$. arbeidsongeschiktheid); of hier gebruik van wordt gemaakt hangt meer van de motivatie van de potentiêle gebruikers zoals BGD-en, af dan van de eigenschappen van de VAG. 


\subsection{Samenratting en conclusies}

Ruim 4500 werknemers uit vier bedrijven werden over een periode van meerdere jaren gevolgd om op het spoor te komen van vroege individuele signalen van vertrek door arbeidsongeschiktheid, vervroegd uittreden (VUT) of ontslagname. Die signalen werden gezocht onder de uitkomsten van werknemersonderzoek met Vragenlijst Arbeid en Gezondheid (VAG) en onder verzuimgegevens (verzuimf requentie en -percentage). Hiermee werden twee doelen nagestreefd, nl. het aantonen van de validiteit van de VAG en vooral: het kunnen voorspellen van latere individuele uitval uit het werk.

De verklarende variabelen (meningen van werknemers via de VAG en verzuimgegevens) werden eerst nader bekeken. De beschikbare verzuimgegevens bleken niet sterk af te wijken van landelijke cijfers. De vragenlijstgegevens bleken, zowel voor de lange als voor de korte versie van de VAG, niet sterk af te wijken van een doorsneepopulatie werknemers. De af zonderlijke werknemersuitspraken bleken het vertrek niet goed te kunnen voorspellen; het was nodig, ze samen te vatten in somscores en indices die betrouwbaar en valide zijn. Deze somscores omvatten de onderwerpen Inspanning, Gezondheid, Ziektegedrag, Materiële Werkomstandigheden, Taak en Werkorganisatie, Leiding en Collega's en Waardering voor de Werkkring. Daarnaast is er een totaalscore en éen van een korte versie van de VAG op basis van 40 vragen. Bovendien werden vier indices geconstrueerd op grond van de samenhang binnen de gegevens en hun samenhang met verzuim en leeftijd. Dit zijn uit de lange versie van de VAG de index Conditie $_{\mathfrak{l}}$ die globaal de lichamelijke conditie weergeeft, en de index Werksituatie die de aanvaardbaarheid van de werksituatie voor de werknemer meet. De overeenkomstige indices uit de korte VAG zijn Conditie ${ }_{k}$ en Werksituatie $_{k}$.

De te verklaren variabelen, nl. vertrek in termen van arbeidsongeschiktheid, VUT en ontslagname werden nader beschouwd over een waarnemingsperiode van drie tot vijf jaar. Het aantal vrouwelijke werknemers bleek in de meeste gevallen te laag te zijn om te behandelen. Gegeven de omvang van het materiaal konden de volgende groepen bestudeerd worden: bij de arbeidsongeschiktheid 
het mannelijk personeel van $35-49$ jaar, $50+$ jaar en het totaal; ontslagname mannen 16 - 34 jaar, 35 - 49 jaar, $50+$ jaar en totaal, vrouwelijke werknemers 16 - 34 jaar en totaal; mannelijk en vrouwelijk personeel tezamen $16-34$ jaar en totaal. Bij de VUT kon alleen het mannelijk personeel worden bekeken. Verder wordt er waar mogelijk gesplitst naar leidinggevenden en uitvoerenden en naar produktie- en overige afdelingen.

Voor alle andere bewerkingen is gecontroleerd of de gegevens van de vier bedrijven zonder correcties per bedrijf samengevoegd mogen worden. Dit bleek het geval te zijn; de resultaten worden niet vertekend door verschillen tussen de bedrijven. Er is daarom geen gevaar dat bij het zoeken naar individuele voorspellers van naderend vertrek bedrijfsverschillen ten onrechte voor individuele verschillen worden aangezien. Bij elke vertrekwijze zijn verder de bewerkingen op de gegevens dezelfde. Eerst worden de verschillen tussen de wel- en nietvertrokken werknemers nagelopen en wordt het vertrek in de loop van de jaren beschouwd. Vervolgens wordt nagegaan wat de kansen op vertrek zijn bij werknemers die laag of hoog op de verklarende variabelen scoren en tenslotte wordt de sterkte van deze voorspellingen berekend. Hieronder worden de resultaten van elk van de vertrekwijzen samengevat.

\subsubsection{Arbeidsongeschiktheid}

De literatuur zegt in het kort het volgende: de meeste arbeidsongeschikten hebben weinig scholing; het zijn overwegend oudere handarbeiders met weinig kans om passend werk te vinden. Eén opvatting van de oorzaak stelt, dat de lichamelijke inspanning tot slijtage leidt, waarbij een slechte fysieke werkomgeving een bijkomende invloed kan hebben op het arbeidsongeschikt-worden. Een andere opvatting is, dat werknemers uitvallen als zij door veroudering de werkeisen niet meer aankunnen of als zij zich niet meer voldoende kunnen herstellen van de arbeidsinspanning. In beide opvattingen zijn werknemers niet meer in staat om zich van de arbeidsbelasting te herstellen.

De resultaten bevestigen dat de meeste arbeidsongeschiktheid bij werknemers boven de 50 jaar voorkomt, maar de leidinggevenden in het onderzoek worden naar verhouding zeker zo vaak arbeidsongeschikt als de uitwoerenden. Verder 
komt arbeidsongeschiktheid bij werknemers in niet-produktieafdelingen in dit onderzoek meer voor dan in de produktie. De conclusie hieruit is, dat arbeidsongeschiktheid niet altijd beperkt blijft tot werknemers met handwerk. Hierom kan ook getwijfeld worden aan de hypothese van alleen lichamelijke slijtage uit de literatuur. Als er van slijtage sprake is, moet deze niet alleen van lichamelijke, maar ook van geestelijke aard zijn. Ook de alternatieve verklaring (een zelfstandig proces van achteruitgang van de arbeids- en herstelvermogens met toenemende leeftijd, waardoor werknemers op een gegeven moment hun werkzaamheden niet meer aankunnen, of het nu gaat om hoofd- of handwerk) is met de resultaten te rijmen.

Een verder element uit de literatuur is de bijkomende invloed van de werkomstandigheden op het proces van arbelidsongeschikt-worden. Uit de resultaten blijkt dat deze invloed niet direct is, maar indirect verloopt. Het is aannemelijk dat ongunstige werkomstandigheden bij jeugdige werknemers kunnen leiden tot latere gezondheidsschade, die bijdraagt aan het arbeidsongeschikt-worden. Hoewel het werknemersoordeel over de werkomstandigheden (de index Werksituatie en zijn samenstellende delen) niet bijdraagt aan de individuele voorspelling (de formele predictie) van arbeidsongeschiktheid, is er alle reden om de werkomstandigheden als oorzaak van arbeidsongeschiktheid te bewaken.

Er werd verwacht, dat de werknemers die dichter bij hun arbeidsongeschiktheid staan meer problemen hebben dan degenen die daar nog verder van verwijderd zijn. Dit is niet zo duidelijk te zien in de enquêtegegevens als in het verzuimpercentage in de jaren voor de arbeidsongeschiktheid. Een hoog verzuimpercentage en een hoge index Conditie (Conditie, en Conditie ${ }_{k}$ uit de lange respectievelijk korte vragenlijst) geven verder een sterk verhoogde kans om arbeidsongeschikt te worden (minstens driemaal zo hoog, vaak meer). Het ligt daarom voor de hand, voorspellingen van arbeidsongeschiktheid in het algemeen te baseren op het verzuimpercentage en de index Conditie (uit lange of korte VAG). Omdat deze in de groep van 50 jaar en ouder beter voorspellen dan het verzuimpercentage en omdat hier de meeste arbeidsongeschiktheid optreedt, zijn hier de indices Conditie ${ }_{\imath}$ en Conditie $_{k}$ hier de belangrijkste voorspellers. 


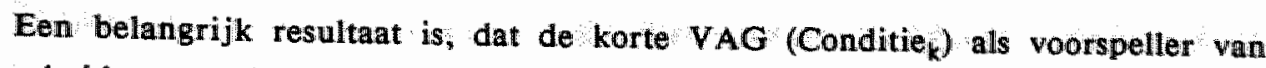
arbeidsongeschiktheid niet onderdoet voor de lange versie van de VAG (Conditie $)$. Bij deze voorspelling hoeft niet de hele lange VAG (117 vragen) afgenomen te worden, maar kan men volstaan met de korte VAG (41 vragen) of zelfs de index Conditie ${ }_{k}$ daaruit ( 15 vragen). Het feit dat korte en lange VAG allebei sterke voorspellers zijn van arbeidsongeschiktheid, en daarin niet voor elkaar onderdoen, betekent dat de predictieve validiteit van beide goed is.

Bij het voorspellen van arbeidsongeschiktheid zijn grofweg drie situaties mogelijk: 1) men kent de werksituatie niet goed en men gebruikt de VAG om zowel die situatie in beeld te brengen als om heit arbeidsongeschiktheidsrisico van de werknemers vast te stellen, 2) de werksituatie is onvoldoende bekend om preventieve maatregelen te ontwerpen; men schat het arbeidsongeschiktheidsrisico met de VAG om met andere instrumenten nader probleemoplossend onderzoek te doen bij de hoogscorende werknemers, die arbeidsongeschikt dreigen te worden, en 3) de werksituatie is voldoende bekend om eventuele interventies te ontwerpen en men gebruikt de VAG alleen om te voorspellen welke werknemers er wel en welke niet arbeidsongeschikt dreigen te worden. In het eerste geval zal men de gehele VAG willen gebruiken (de lange of de korte versie van de VAG, afhankelijk van de informatiebehoefte). In het tweede en derde geval kan men vaor het screenen van de werknemers op anbeidsongeschiktheid volstaan met de vragen van de index Conditie (weer: korte of lange versie, zie boven), dus met de halve VAG.

Aan de hand wan de resultaten worden suggesties gedaan hoe men, rekening houdend met de concrete situatie, laag- en hoogscorende werknemers kan onderscheiden met het oog op de preventie van arbeidsongeschiktheid. Bij de hoogscorende werknemers kunnen corrigereerde maatregelen in de werksituatie worden genomen.

\subsubsection{Vervroegd uittreden}

De literatuur over vervroegd uittreden (VUT) noemt als belangrijkste determinanten van de VUT een slechte verhouding tussen belasting en belastbaarheid in 
het werk en het uitzicht op een behoorlijk inkomen na uittreden. Over het laatste zijn in dit onderzoek geen gegevens voorhanden, over het eerste wel.

De toekomstige vervroegd-uittreders voelen zich, in tegenstelling tot het beeld uit de literatuur, niet overbelast, het tegendeel is waar. De werknemers die met de VUT gaan hebben lagere scores (minder problemen) dan de vergelijkingsgroep wat betreft Inspanning, Gezondheid en Ziektegedrag, een lagere index Conditie (Conditie, of Conditie ${ }_{k}$ ) en een lager verzuimpercentage.

De relatie tussen deze voorspellers en het individueel toetreden tot de VUT is niet heel sterk. Werknemers met een lage waarde op de genoemde somscores en een lage index Conditie $e_{l}$ of Conditie $_{k}$ hebben een anderhalf tot tweemaal zo grote kans om met de VUT te gaan dan degenen met hogere scores, maar de samenhang is niet perfect. Wel zijn de groepsverschillen tussen niet- resp. wellVUT-groep consistent. Wat betreft de validiteit van de VAG betekent dit, dat de VUT-resultaten bijkomend bewijs vormen voor de validiteit van de VAG.

\subsubsection{Ontslagname}

De verwachtingen op grond van de literatuur ten aanzien van ontslagname zijn, dat het om betrekkelijk jonge werknemers gaat, die op alle mogelijke werkaspecten (dus ook alle somscores en indices) en verzuimmaten hoger uitkomen dan de niet-ontslaggroep. Het eerste werd bevestigd, want de meeste vrijwillige ontslagnamen vallen in de groep 16 - 34 jaar, zowel bij mannelijke als vrouwelijke werknemers. De tweede verwachting ligt ingewikkelder.

Wat betreft de problemen van degenen die met ontslag gingen, werd niet in alle groepen werknemers hetzelfde patroon gevonden. Bij de grootste groep, nl. de mannelijke werknemers in de produktie-afdelingen (de madalle werknemer) blijkt dat ontslagname meer te maken heeft met de werkinhoud, -omstandigheden en verzuimfrequentie dan met de gezondheid, inspanning en verzuimpercentage. De enige gegevens die een zekere voorspelling van ontslagname opleveren zijn de twee indices Werksituatie, en Werksituatie $_{k}$. Hun voorspellende 
kracht voor individuele ontslagname is echter gering, ook als ze gecombineerd worden met de verzuimf requentie.

Hieruit kunnen twee conclusies worden getrokken: ten eerste dat lang niet alle factoren uit de literatuur even zwaar wegen in de beslissing tot ontslagname; ten tweede dat er geen sterke individuele voorspellingen van ontslagname mogelijk zijn met het beschikbare type gegevens. Dat de verbanden tussen de voorspellende variabelen en ontslagname niet sterk zijn betekent waarschijnlijk dat de actuele werksituatie veel minder invloed heeft op het besluit tot ontslagname dan

a) de neiging van jonge werknemers om vaak van werknemer te wisselen en

b) factoren buiten de werksituatie, zoals een huwelijk of de kans op nieuw werk.

Wat betreft de validiteit van de VAG gezien de resultaten bij ontslagname is de conclusie ongeveer als bij de VUT: de ontslagname hangt op individueel niveau niet sterk samen met de VAG. Er zijn echter duidelijke groepswerschillen tussen de toekomstige wel- resp. niet-ontslaggroep: verschillende aspecten van gezondheid, arbeidsinspanning en werksituatie zijn in de ontslaggroep relatief problematisch. Deze verschillen dragen bij aan de validiteit van de VAG.

\subsection{Aanbevelingen}

Uit het onderzoek bleek dat de VAG een betrouwbaar en valide instrument is om werknemers hun gezondheid en werksituatie te laten evalueren. Verder bleek dat de VAG bruikbaar is woor een doell, waarvoor zij oorspronkelijk niet werd ontworpen, namelijk het voorspellen van het vertrek van werknemers. In het voorgaande zijn al impliciet enkele aanbevelingen genoemd. Hieronder worden ze gegroepeerd naar methoden van onderzoek, vroege signalering van uitval en nader onderzoek. 


\subsubsection{Methoden van onderzoek}

1. Vragenlijsten blijven niet onveranderd in de loop van de jaren; stapt men over van de ene op de andere lijst (bijv. naar de VAG), dan zou bij minstens éên groep werknemers zowel de oude als de nieuwe lijst afgenomen moeten worden met het oog op de ijking en de vergelijkingsmogelijkheden.

2. Er bleek, dat antwoorden van werknemers op afzonderlijke vragen weinig voorspellende waarde ten aanzien van latere uitval hebben, en dat samenvattende scores hierin beter zijn. Bij soortgelijk onderzoek zou hier rekening mee gehouden moeten worden.

3. Omdat verzuimgegevens voorspellende waarde bleken te hebben, zeker voor arbeidsongeschiktheid, en omdat deze gegevens gemakkelijk te verkrijgen zijn, zouden ze altijd in prospectief werknemersonderzoek meegenomen moeten worden.

4. De werknemersmeningen in het onderzoek waren niet longitudinaal, maar eenmalig verzameld, omdat herhaalde ondervraging niet mogelijk was. Er is een rangorde van wenselijke maar arbeidsintensieve naar gemakkelijker uitvoerbare werkwijzen:

a. zowell verzuimgegevens als werknemersmeningen longitudinaal verzamelen als mogelijke voorspellers van uitval;

b. alleen verzuimgegevens in de tijd volgen en slechts nadere vragen stellen aan werknemers bij wie een toename in het verzuim blijkt;

c. alleen verzuimgegevens verzamelen in de tijd en daarin zoeken naar werknemers met een toename in het langdurend verzuim.

5. Wie arbeidsongeschikt wordt bereikt de VUT niet en andersom; arbeidsongeschikten hebben in een eerder stadium veel klachten waar de VUT-groep er weinig heeft. Arbeidsongeschiktheid en VUT zijn elkaars spiegelbeeld, ze zouden daarom in onderling verband bestudeerd moeten worden. 
6. De factor 'leeftijd' speelt bij alle vertrek van de werkplek een overheersende rol; om banale voorspellingen te vermijden moet de leeftijd niet als éen van de verklarende variabelen naast andere gebruikt worden, maar als principe van stratificatie. Binnen leeftijdsgroepen kan wel zinvol naar verbanden worden gezocht.

\subsubsection{Signalering van naderende uitval}

7. Problemen van werknemers met hun gezondheid, inspanning en ziektegedrag, gemeld met de Vragenlijst Arbeid in Gezondheid (VAG), bleken goede voorspellers van arbeidsongeschiktheid te zijn; bij het bewaken van gezondheidsrisico's in de arbeid in het algemeen zouden deze variabelen gebruikt kunnen worden.

8. Door aan de voorspelling van arbeidsongeschiktheid op grond van werknemersmeningen het verzuimpercentage toe te voegen kan de precisie (sensitiviteit) van de voorspelling worden verhoogd.

9. De werknemers die in de VUT gaan hebben minder problemen en verzuim dan degenen die na de VUT-leeftijd doorwerken. Er zou daarom in de werksituatie extra aandacht besteed moeten worden aan degenen die niet van de VUT gebruik maken.

10. De uitkomsten wat betreft arbeidsongeschiktheid stroken met de bewaking van belasting en belastbaarheid in de bedrijfsgezondheidszorg. Het is misschien van belang, belasting en belastbaarheid systematisch in de tijd te volgen, niet alleen door meten, maar ook door vragen aan werknemers.

11. Bij het voorkómen van arbeidsongeschiktheid zijn de index Conditie (uit korte of lange VAG) en het verzuimpercentage globaal goede voorspellers; de index Conditie (lang of kort) is echter de belangrijkste van de twee, omdat deze het sterkst is bij de oudere werknemers $(50+$ jaar) waar de meeste arbeidsongeschiktheid optreedt. 
12. Wanneer de werksituatie niet in kaart gebracht is en men wil arbeidsongeschiktheid voorspellen, dan is het aangewezen, de gehele VAG (korte of lange versie) te gebruiken; is de werksituatie wel bekend en wil men alleen het arbeidsongeschiktheidsrisico schatten, dan kan men volstaan met de halve VAG, nl. de index Conditie (korte of lange versie).

\subsubsection{Nader onderzoek}

13. In onderzoek naar toetreden tot de VUT zou altijd het verwachte inkomen betrokken moeten worden.

14. Nagegaan zou moeten worden of de werknemers die in de VUT zullen gaan, altijd minder problemen hebben met arbeid en gezondheid dan degenen die niet in de VUT zullen gaan.

15. Bij het onderwerp 'ontslagname' is niet duidelijk geworden of de ontslagname zelf als goed, neutraal of slecht moet worden opgevat. Er zou onderzocht kunnen worden onder welke omstandigheden ontslag gunstig dan wel ongunstig is voor de werknemer en voor de organisatie.

16. Er zijn in het onderzoek weinig vrouwelijke werknemers, er zou daarom bij deze groep een parallel onderzoek verricht moeten worden naar de voorlopers van vertrek. 


\section{LITERATUUR}

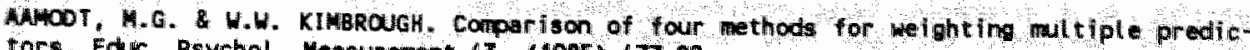
tars. Educ. Psychol. Measur ement 43 (1985) $477-82$.

MRTS, L. Bedrijven en arbeidsongeschiktheld: on poging tot verklaring van bedrijfsge wijze verschillen in invallderingspercentages. Leiden, Centr. Onderz. Econ. Publ. Sector RULl, 1984. (rapp. a4.11).

MARTS, L., H. BRUINSMA, H. EMAHUEL e. A. Determinanten van wa-tootreding: en terste verkenning. Econ. Stat ist. Ber.66 (1981) 3331, p. 1132-8.

MARTS, L., H. BRUINSIMA \& Ph. DE JOWG. Arbeidscapaciteit ven Who-toetreders: deelrapport Determinantenonderzoek WA. Zoetermeer, socfale Verzekeringsraad, 1982a.

MARTS, L. H. BRUIWIMA \& Ph. DE JONG. Beschrijving van WhO-toetreders. Soc Maandbl. Arbeid 37 (1982b) $560-86$.

MARTS. L., H. BRUIWSMA \& Ph. DE JONG. Beschrijving van WAO-toetreders: deelrapport Determinantenonderzoek WAO. Leiden/Zoetermeer, Centr. Onderz. Publ. Sector/Socialle Verzekeringsraad, 1982c.

AARTS, L.J.M. P.R. DE JONG. Economic aspects of disability behaviar (EConomische aspecten van gedrag inzake arbeidsongeschiktheid). Proefschrift Erasmus Universiteit Rotter. dan, 1990 .

ABRAMSOH, J.H. The Cornell Medical Index as an epidemiological tool. Amer, J. Public Heal th $56(1966) 2,287-98$.

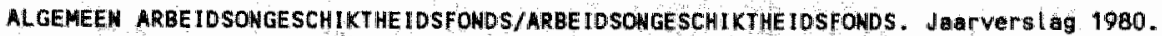

Zoetermeer, AMF/AOf, 1983.

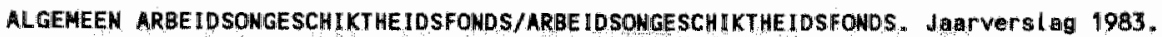

Zoetermeer, MAF/Áaf, 1985.

ALGEMEEN BURGERLIJK PENSIOENFONDS. Jaarverslag 1986. Heerlen, ABP, 1987.

ALGEMEME ARBEIDSONGESCHIKTHEIDSWET. Wet van 11 decenber 1975 (Stb. 674) tot vastatelling van een algemene arbeidsongesch iktheidsver zekering.

ALGEMENE BURGERLIJKE PENSICENHET. Wet van 6 januari 1966 (stb.6) houdende nieuwe regeting wan de pensibenen van burgerlijke ambtenaren en van hun nabestamden.

ALIWG, H. De InInder-valide oudere werknemer; een socjal geneeskundig onderzoek ohtrent 37 mannen van 55 tot 65 Jaar die een invaliditeitsrente hebben angevrangd. Proefschrift K.U. Wijmegen, 1969.

MPPELS, A. Screening als methode voor preventite in de geestel ijke gezondheidszorg. Proefschrift Eramus Universiteit Rotterdam, 1975.

APPELS, A. Vitale uif tputting als voorloper van het hartinfarct. Hartbull tetin 18 (1987) 5 , $135-139$.

ARBEIDSOMSTAMDIGHEDENLET. Wet Van 8 novenber 1980 ( $3 t$ b. 664) houdende bepal ingen in het belang van de veiligheid, de gezondheid en het welzijn in verband met de arbeid.

ASTRAMO, M. -E., S.-E. ISACSSON G.O. OLMAGEM. Priediction of early retirement on the basis of heal th examination. Scand. J. Work Environ. Health 14 (1988) 110-7. 
aART, I. De oudere hovenwerker; aspecten wan zi in cardiorespiratoirie conditie. Erasinus universil telt fot terodiai, 1973.

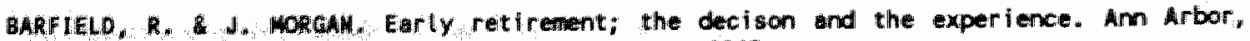
Inst. Soe. Res univ. Hichigan, Surv. Res. Center, 1959.

Ax, E.H. Matachappalj Ije veranderfing en arbeldsomeschlktheid; de macto-deterainanten

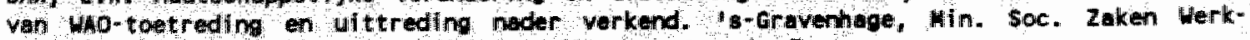
gelegent. Com. Onderz. Soc. 2ekert. 1984. (cosz reeks 3).

BEKE, LH.d. OP DEN. Herziening trendinat Ig arbeidsaarbod 1985-2000. "s-Gravenhage, Cencraal Planburaau, 1987.

BERTING, $J$. In het brede matschappelijke midden: een studie over middelbart achinifitraltheve employes in grote organisaties in Ansterden. Heppel, boom, 1968.

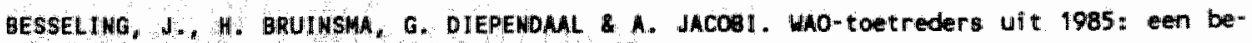
scriliving. Amsterdah, Gwo, 1987 (G)-cahler 12).

BEYERINCK, C.W. (RAPPORTEUR). Periodieke keuringen: verslag wan het symposium in de vergadering van de Ned Ver. voor Arbeids- en Bedrilfsgeneeskunde op 9 Januart 1957 te Musterdan. $T$, soc. Geneesk. 35 (9957) 555-67.

BIMLSMA, T. F. KoopMAtis. Bedrijfsvereniging en arbeidsongeschiktheid. T. Soc. Gezondheldsz. $62(1904) 535-43$.

MLOEMHIFF, A. P.G.W. SHULDERS. De toekomst van de kwalliteit van arbeld, gezondheid en welzijn: een onderzoek uitgevoerd door het Mederlands Instituut voor Praevent feve Gezondheldszorg te Leiden in samenwerking met de Scenariocomissie Arbeid en Gezondheid en in apdracht van de stuurgroep Toekonstscenario's Gezondheidszorg (in voorbereiding).

BLOM, L.H. WUT: analyse van een verschijnsel in ontwikkeling. Soc. Maaribl. Mrbeid 38 (1983) $95-103$.

giluebork, A.C. The theories of turnover causes, effects, and meaning. Res. Sociot. Organiz. 1 (1982a) $75-128$.

BLUEDORH, A.C. A unified model of turnover fron organizations. Hum. Relat. 35 (1982b) 2, $135 \cdot 53$.

BOLHUIS, E.A., S.J. OTTENS H.A. STEENBEEK-VERVOORT. De WuT met pensioen. Econ.-Statist. Ber. $72(1987) 3617,726-8$.

BOOROER, TJ. DE, Ouder worden en werken. T, Soc. Genews. 57 (1979) 421-3.

BOSCH, F.A.J. VAN GEH \& C. PETERSEN. De omvang van de verborgen werkloosheid in de WAO. Econ. Statid. Ber. $65(1980 a) 52-80$.

BOSCH, F.A.J. VAN DEN C. PETERSEA, Arbeidsongeschiktheld als econanisch begrip. Econ." Statist. Beil\%. (1980b) 13:44-50.

BOSCH, F.A.J. VAN OEN C. PETERSEN. De omwang van de verborgen werkloosheid in de WAO. IN: F.A.J. van den sosch \& C. Petersen (red.). Arbeidsongeschiktheid; een inultidisciplilnal re benadering. Deventer, KLuwer, 1989, PP. 77-95. (S0c. Zekerheidsreeks 7).

BOSCH, F.A.J. WAN DEN C. C. PETERSEN. Incidence of disability by sector of industry: an explanation. Int. Soc. Secur. Rev. 35 (1982a) 196-204.

aOSCH F.A.J. VAN DEH \& C. PETERSEM. Een economische anolyse van de non-participatiegraad; de invloed van arbeidsongeschiktheid. Waandschr. Economile 46 (1982b) $307-21$. 
BOUTER, L.M. M.C.J.M. VMN DONGEA. Epildeniologiseh onderzoek en interpretatie. Utrecht, ctc.. Bohn, Schel tena Holkema, 1988.

AREED OVERLEG ARGEIDSONGESCHIKTHEID. Samenvattend verslag van de aktiviteiten van het Breed Over leg Arbeidsongeschiktheid t. a.v. "Prevent fe van ongeschikte arbel id " $1986-1989$. 2.P., BOA, 1989 .

BRESLOW, W.E. \& M.E. DAY. Statistical methods in cancer research, Vol, I: The analysis of case-control studies. Lyon, WHO International Agency for Research on Cancer, 1980; (IMRC Scientific Publications No. 32).

RELEKELEN, J.W.M. VAN Personeelswerloop in organisaties: een litereturaverzicht en een model. Gedrag arganisatie 1 (1989) 6, p. 37-65.

BROEKHUIs, d.J. Becordeling en begeleiding bij arbeidsongeschiktheid. Proefichrift R.U: Groningen, 1986.

CASEY, B. Earliy retirement: the problems of instrument substitution and cost shifting and their implication for restructuring the process of retirement. Int. Soc. Secur. Revi 40 (1987) 4, p. 343-60.

CENTRAAL BUREAU VOOR DE STATISTIEK. Statistisch Zakboek 1971-1988. "s-Graventhage, Staatsuitgeverij, 1971 - 1987 .

CENTRAAL QUREAU VOOR DE STACISTIEK. Arbeidiskrachtentelling 1979. "s-Gravenhage, staats"Uitgeveri i , 1982角.

CEMTRAAL BUREAU VOOR DE STATISTIEK. Prognose wan de bevolking van Wederland na 1980. 's Giravenhage, Staatsuitgeveri $j_{\text {, }} 1982 b$.

CENTRAAL BUREAU VOOR DE STATISTIEK. Mabndstatistiek van de bevolking 5 (1988a).

CENTRAAL BUREAU VOOR DE STATISTIEK. Maandstatitiek van de bevolking 12 (1988b).

CENTRAAL BUREAU VOOR DE STATISTIEK. Bevolkingsprognose voor Nederl and 1988-2050. "G-Gramwenhagle, staatsuit tgeverij, CBS-publ icaties, 1989.

CentraAl Planbureau. Centraal economisch plan 1987. 's-Gravenhage, Centraal Planbureau, 1987.

CHILD, J. \& A. KIESER. Development of organizations over time. In: P.C. Nystrom \& W.H. starbuck (eds) Handbook of organizational desigri, Vol. I: Adapting organizations to their environments. Oxford, Oxford Univ. Press, 1981, PP. 28-64.

CHIRIKOS, T.N. Accounting for the historical rise in wark-disability prevalence. The Milbank Quart. 64 (1986) $2,271-301$.

CHIRIKOS, T:N. G. MESTEL. Impailrment and labor market outcomes: cross-sectional and llangitudinal analysis. In: H.S. Parnes (ed.) Work and retirement: longitudinal study of men. Cambridge (Mass.) etc. "The HIT Press, 1981. Pp. $93-131$.

CHRISTELIJK NATIONAAL VAKVERBOND. CNV-actieplan arbeidsongeschiktheid. Utrecht, CNV, 1990.

CLARK, R.L. The future of work and retirement.. Res. an Aging 10 (1988) 2, p. 169-93.

COTTON, J.L. \& J.M. TUTTLE. Emplovee turnover: a meta-analysis and review with implica" tions for research. Acad. Manag. Rev. I1 (1986) 1, 55-70.

DIENST SOCIAAL-WETEMSCHAPPELIJK ONDERZOEK (DSWO). Samenwattende publ ikatie onderzoek verwroegde uit reding. Leiden it subfac. Psychol RuL Vakgr. Meth. Techn., 10swo, 1979. 
DIJK, F. VAM, O.A. VIM HASELEM D.E. LENSHOEK. Verschll in WHO-toetredingsilisico. Ansterden, stichting cCOZ, 1985.

DIJK, F.J.H. VAN, D.A. VAM hASELEN, D.E. LEMSHOEK, P. HELLIWGA, S. DE BOER C. KOFFEMAM. who-toetreding: trends on rlsilcogroepen in en groot industrièel bedrijf. T. Soc. Gezondheldaz, 65 (1987) $654-62$.

DluKstah, A. Determinaniten van zlekteverzuím in produkt leorganisaties woor gehandicaptien. Proefschrift R.U. Lelden, 1977.

DIJKSTR, A. Zfekteverzuim en non-response: respresentativiteit van deelnome aan enqueteonderzoek in arbelidsorganisaties ten aanzlen vain een te verkllaren variabele." Gezondh. \& sament. 2 (1981) $4,266-73$.

DIJKSIRA, A., M.P. MAN DER GRIMTEN, H.J.Th. SCHLATHAWH \& C.R. DE WIMTER. Funktioneren in de arbefdssituatie: ultgangspunten, ontwerp en hendleiding voor onderzoek onder werknemers naar gezondheld, werk en werkonstandigheden. Leiden, WIPG/TWO, 1981..

DIJKSTRA, A., M. VAN DER GRIHTEW, M. SCHLATMHNM \& C. DE HIWTER. Maatwerk; over werknemers en hun werksituatfe. Utirecht, Het Spectrum, 1983 (Aula paperback 92 ).

DOUBEW, $N, H$, M. HERWEIJER, etc... Arbeidsmarkt, werkloosheid en arbeidsongeschiktheid. Maandsch. Economie 43 (1979) 309-20.

ORAAISMA, $D$. Ziekteverzuim, WAO-intrede en verzekeringsvorm in de $z$ jektewet: een onderzoek onder 119 bedrijven naar achtergronden van verschillen in arbeidsongeschiktheid bij afdel ingskassen, elgen-risïcodragers en onstagleden. Leiden, NIPG/TNO; s-Gravenhage, Min. Soc. Zaken Werkgelegenh., 1983.

DRAAISMA, D., R.W.M. GRUWDEMAMN \& H. HOOLBCOM. Taak, gezondheid en welbevinden van uitvoerders in het bouwbedriff. Leiden, NIPG/TWO, 1985

DRAAISMA, D., R.W.M. GRUNDEMANN \& H. HOOLBOOM. Werlk en gezondheid van witvoerders in het bouwbedrijf: een longitudinaal anderzoek onder bujvers en wïtvallers in de periade 1983 - 1987. Leiden, MIPG/THO, 1989.

DRAAISMA, D., R.H. DE HAAN, H. KUIPERS \& P. SHULDERS. Aktieprogramma 2 f ekteverzuim: eindrapport. Leiden, MIPG/TWO, 1976.

DRAMISMA, D. P.G.W. SMULDERS. Ziekteverzuim en het bedrijf: achtergronden, registrat lie, onderzoek en mogelijke maatregelen. Leiden, etc.., Stenfert Kroese, 1978.

DRIVER, M.J. Careerg: a review of personal and organizational research. In: C.L. Cooper * Ii. Robertson (eds): International review of industrial and organizational psychology 1988. Wew York tc., Hilley, 1988. Pp. 245-77.

DUCKWORTH, D. Terminalogy in relation ta disablement. In: W.T. Singleton \& L.M. Debney (eds) Occupational disability; the approaches of government, industry and universities. Lancaster, MTP Press, 1982, Pp. 17-26.

DUL, J. C.K. PASMOOIJ. Arbeidsonstiandigheden en arbeidsplaatsverbetering in de meubell industrie. Voorburg, Dir. Gen. van de Arbeid, 1985. (rapport s15).

EINERHAND, M.G.K. Ufttrede wit het arbeidsproces: werken en niet-werken van 50-64-jarige mennen in Nederlland. Stat ist. Mag. 6 (1986) 4, 15-23.

EKXER, W. De verzuimonderzoekingen van het Nederlands Instituut voor Praeventieve Geneeskunde. Mens Onderneming 16 (1962) 267-80.

FEDERATIE NEDERLAMDSE VAKBEWEGIHG. Een gezonde $k i j k$ op arbeids(on)geschiktheid " aanglepaste arbeid en de passende werkgever. Ansterdam, FWV, $19 \% 0$. 


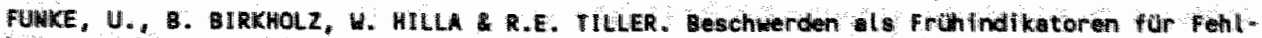
beanspruchiung Arbeftsplatz? Arbeitsmed. Sorfalmed. Pravamt wmed. 23 (1988) $281-7$.

GoounEx, 1. Absences and well-beiting of workers soctal matnix of absence-behavilour, siatisfaction and some other st ticudes in contrasted proups of workers from large industrial plants in the Metherlands. Mssen, Van Corcun/Prakke Prakke, 1965.

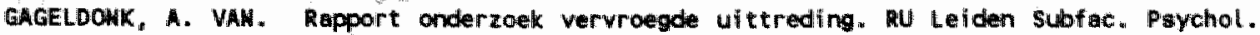
Wakgr. Heth. \& Techn. Mosto, 1978.

GALAN, C. DE. Ontwikkelingen in het verschijnsel abeidsongeschiktheld. Soc. Marandbi: Mrbeid 35 (1980) $888-93$.

GEMEENSCHAPPEL IJKE MED ISCHE DIENST. AAW/WAO kernc If fers 1987. Ams terdam, GHo, 1988.

GIDS PERSONEELSBELEID. Eerder uit het arbeldsproces: platats naken voor een werklaze. Gids Personelsbel. B (1975) 201-4.

GIEL, R. De verzekeringsgeneeskundige de ziekenrol respectlevelijk het ziektegedrag van de verzekerde: Arts \& Soc. Verzekering 15 (1977) 40-5.

GINNEKEN, P.J. VAN (red). VUT: vervroegde vittreding in ontwikkeling. Win. Soc. Zakent Werkgellegenth., 1981.

GOUDRIAAN, F.G.W., A.H. MIEUWLAWD, E.C. SCHOKKIMG-SIEGERIST \& T.J. VEERMAN. VerZUIN IIn het onderwijs: samenvatting van de resultaten van het werkennend onder zoek. Leiden, R.t. Fac. Soc. Wet, Herkgr; Arbeidsvragist. Welzijn, 1982.

GoULD, R. The background and work history of persons applying far disability pensions. In internat. soc. Secur. Assoc. social security and disablitity istues in polity research. Gieneve, ISSA, 1981. Pp. 55-76.

GRAAF, L. DE. Onderzoek in toekomst beter toesnijden op de praktijk. Hed. Staatscourant 222, nov. 1982 .

GROOT, M.J.W. DE. BetekenIs van de niet-medische oorzaken van ziekteverzultm voor het Hederllandse bedrijfs leven. Mens \& Ondernening 8 (1954) 250-68.

GROOT, M.J.W. DE. Kanttekeningen bij enkele anbevelingen uit het interimrapport van de commissie tot onderzoek van de invloed wan het ziekteverzuim op de arbeidsproductiviteit. Mens \& Onderneming 9 (1955) $219-225$.

GoOTHoFf, Jw. Gezondheldstoestand van de beroepsbevalking: on tudie mar de indicatoren arbelidsongeschiktheld, sterfte, gezondheidezorg. Proefschrift R.U. Groningen, 1926

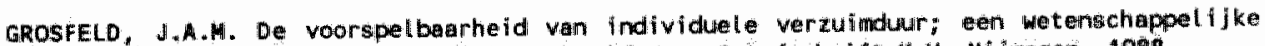
proeve op het gebied van de sociale wetenschappen. Proefschrift $\mathrm{K}$.U. Wijmegen, $198 \mathrm{~B}$

GUILFORD, J.P. Psychometric methods. New York etc. "McGriatinill, 1954 .

HAREN; 1.A.C. VAN. Ontslagrecht algeneen. Prakt, Personeelsbel, (1980) $24 p \mathrm{pl}, 9.2,1.23$.

HAVEAAM, R.H. On the determinants of growth in disability income support: conference overview. In: H. Emanueh, E. H. de Gier P.A. Kalker Konfjn (eds) Disability benefita: factors deternining applications and awards. Greenwich/londen, JAI Presis, 1987, 265-75.

HEETEN, H. DEH, H. KAAY, P. VAN VEEN 2 T. VERSCHUREN. Preventie van ongeschikte airbeid. Hoofdidorp te. RIAH/RIAGG, 1987.

HERWEYER. H. Arbeidsongeschiktheid als een vorm van vervrogide uftreding cerontologie $12(1981) 91-703$. 
Werwerer, W. Groel en krinp in de wo. Beleldswetenschap 1 (1987) 1, p. 37-59.

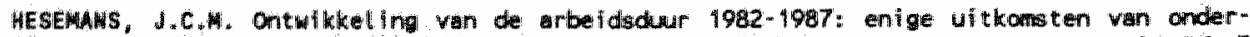

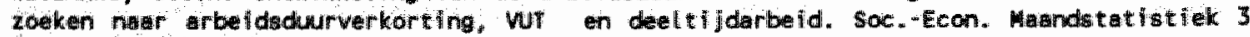
(19a8) suppl. 4.12.

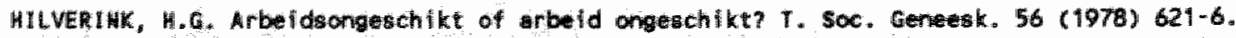

HONZIK, M.P. Llfe-spen developnewt. Am. Rev. Psychal. 35 (1984) 309-31.

Hookovews IJWIDEN, Evaluatie van het experiment vrlfilltig vervroegd uftereden uit het arbeldsproces woor 63 - 64-jerige werknemers bil Hoowowens IJmuiden av. IJmuiden, Psychol. Dienst Hoogovens IJmuiden, 1979.

HORST, F.G.E.H. VAH DER. Gezoncheid en niet werken; een vergelijkend onderzoek nar gezondheid en liedwilze van werkloze, arbeidsongeschikte, wervroegd gepensioneerde en werkende mannen. Proefschrift R. U. Limburg, 1988.

HOWAR, A. Who rewches for the golden handshake? Acad Manag. Exec. 2 (1988) $2,133-44$.

HULLENAAR, R.H.J. VAN 'T \& D.B.J. VAM KOWINGSVELD. Oudere werknemers: belleving van merk en wan verzuim; verslag wan een on derzoek naar de relaties tussen arbelidsongeschilktheid bif oudere weriknemers in industriele bedrijuen en hun arbeidsbelasting, arbeidsbeleving en welbevindem. "s-Groverhage, COB/SER, 1982.

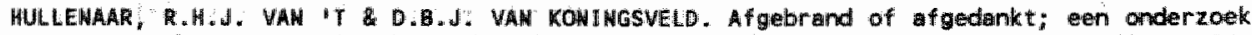
naar oortaken van arbeidsongeschiktheid. Lisse, Swets zeitlinger, 1986. Proefschrift K.U. Wi jmegen.

HUNFELD, A. Werkloosheid, WAO on ABP. In: V. Vrooland et al. WAO en werkgelegenheid: een discussie over een recente schatting van de "verboirgen werkloosheid" in de WAO. Ansterdam, stichting ccoz, 1980 . Pp. $26-56$.

JACOASOA, D. Will ingness to retire in relation to job strain and type af work. Industr. Gerontol. $13(1972) 65-74$.

JOWG, Ph. DE, H. BRUIMSMA, L. AARTS H.P. HOP. Determinantenonderzoek WHO: semen* werkingsproject van de socilale verzekeringsraad en het centrum voor onderzoek van de Economie van de Publiske sector qu Leiden. Zoetermeer/Leiden, SUr/CoEPs, 1981.

Jow G, R.D. DE. Sociale ondersteuning, spanning en steming: functioneren en gezondheid bij ondernemers monagers. Proefschrift R.U. Utrecht, 1987

KABELA, M. Psychlatrisch oordeel beoordeeld; de psychiatrische beoordeling wan arbeidsongeschiktheid "Leiden, 1988. Proefschrift RU Leiden.

KARASEX, R. B. GARDELL A I. LIMDELL. Work and mon-work correlates of illness and behaviour in male and fenale \$wedish white callar workers. J. Occup. Behav 8 (4987) 187202 .

KERKHOFF, H.H.C. Ouder worden, verouderen en het persaneet sbeteids case-studies naar het proces van auder worden wan werknemers in de industrie. Proefschrift UWA, 1981.

KERKKOFF, W.H.C. Ouder wordende werkneners: herbezinning op social beleid noodzakelijk. Medium 11 (1982) 4, 33-7.

KERKHOFF, W.H.C. J. JAMSEN \& J.M.A. MOLENAAR. Ondernemingsbelefd, kWal iteilt van de arbeid an voorti jige wittreding van oudere werknemers: een onderzoek in opdracht van de SOOH. Amsterdam, ISBP UVA, 1987.

KERS, W.C. H. BRUIMSMA. WHO-toetreders 1987: cen beschrijving. Ams terdam, Gemeenschappelijke Medische Dienst, 1989. 


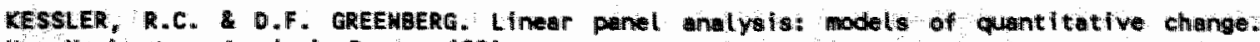
Wen Vork etc., Acadenic Press, 1981.

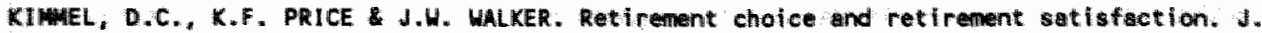
Gerantel. $33(1978) 575-85$.

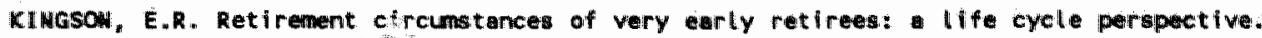
Heing wark 4 (1981) $161-74$.

KIMGSON, E.R. The health of very earty rethees. Aging B Work 4 (19810) $11-21$.

KLEINBAUH, D.G., L.L. KUPPER \& H. HORGENSTERA. Epidemiologic research: princlples and quantitative methods. Selmont etc. Lifetime Learning, 1982.

KLOOSTERMUIS-DUIRKER, H. Dreagkracht en dratalast van de oudere werkende wroumi. T. Soc. teneesk. 57 (1979) 589-91.

KLUMER. Meno stelselherziening. Deventer, Kluwer, 1987 .

KHAAPEN, A.L.M. Einde dienstbetrekking. Prakt isch Personeelsbel. 7 (1980) suppl. 37, hst: B-1, 1-2.

KOMPIER, M.A.J. Arbeid en gexondheid van stadisbuschauffeurs. Proefschrift R.U. Groningem, 1988.

KOMPIER, H., T. MEIJMAW, H. MULDERS R. BULLIHGA. Onderzoek naar de relatie tussen zlekteverzuim en arbeidsongeschiktheid van stadsbuschauffeurs. 1. Soc. Gezandheldsz. G4. (1986) $477-480$.

HOMPIER, H., H. MULOERS, T. MEIUMAN, M. BOERSHA, G. GROEN \& R. BULLINGA. Absence behavi our, turnower and disability a study anong city bus drivers in the Netherlands. Work Stress 4.1990$) 1,83-9$.

KONINGSNELD, D.B.J. VAH, H.W. VAH DEN BORNE, R.H.JW. VAN IT HULLEHAAR \& J.F.J. JAMMAAT. Viri jwillig vervroegde ufttreding in de metalindustrie: beschrijving van uittreders en niet-uittreders, en invlaed van de regeling op de werlikgelegenheid; tweede onderzoeksfase. Berg en Dal, stichting GITP, 1978.

KONINGSVELD, D.B.J. VAN \&.J. VAN GIMNEKEN. VUT, nu en straks. Assen etc." Van Gorcum, 1988 .

KoOPHAMS, F.G. \& T, BIJLSWA. Ongel 1 jkheid in ZW en WAO. Proefschrift UVA, 9990

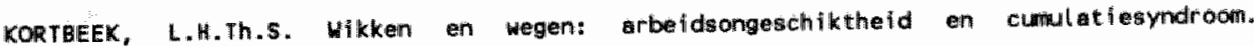
Metmedica $53(1974)$-6.

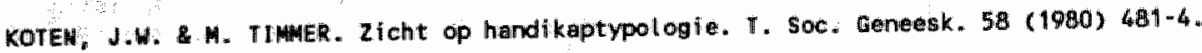

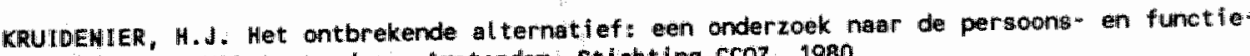
kenmerken wan WA-toetreders; Amsterdam, stichting CCOz; 1980 .

KRUIDENIER, H.J. Afwezig wegens zlekte of ....? In: H.J. Kruidenier et bil zlekteverzulm en kwaliteit wan de arbeid. Deventer, Kluwer, 1982a, Pp. 9-25.

KRUIDENIER, H.J. Arbeidsbelesting en de karis op langdurlge arbeldsongeschiktheid. In: V.C. Wrooland (red.): Werk en gezondheid: over ziekteverzuim er humanisering van de arbeid. Alphen a/d Rilin etc., Samsam, 1982b, Pp. 35-46.

KRUTDEAYER, H.J. Ziektewerzuim en verloop: en literaturstudie naar het verband tusisen thee indiketoren voor velligheid, gezonthelid en welzijn. Amsterciam, stichting ccoz, 1984 . 


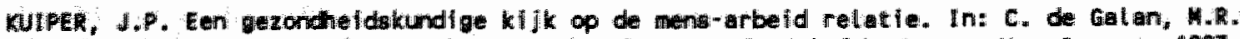

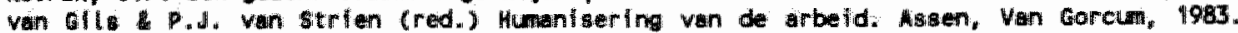
Pp. $181-269$.

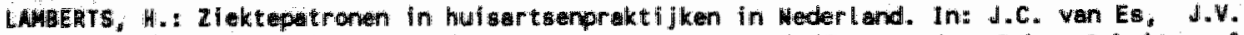

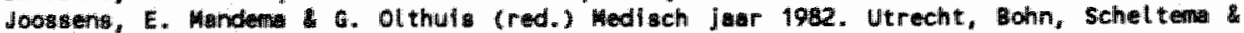
Holkend, $1982, \mathrm{Pp} 13-36$.

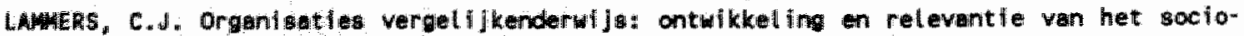
logi isch denken over organfiatles. Utrectht etc. Het spectrug, 1987 (Aula-boeken).

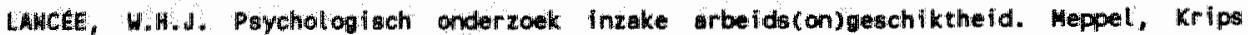
Mepro, 1980. Proeftehrift RU L Limburg 1908.

LMZARSFELD, P.F. Evidence and Inference in social resedrch. In: D. Lerner (ed.) Evidence and inference" the Hayden colloquilu on scientific concept and method. Glencoe, Free Press, 1959 .

LEEAREIZE, H.J. De FWV en de vrijullig verwroegde uittreding van oudere werknemers. Soc. mandol. Arbeid 34 (1979) $305-11$.

LEMSHOEK, D.E., S. DE BOER, C. KOFFEMAN \& P. HELLIMGA. ZiekteduHr, diagnosie en werkherWatting. T. Verzekeringsgeneesk. 27 (1989) 1, 6-10.

LENSHOEK, D.E., D.A. WAN HASELEN, F. VAN DIJK, S. DE BOER, P. HELLINGA \& C. KOFFEMAN. Trends en bewegingen bil jeintegratie. I. Soc. Gezondheidsz. 66 (1988) 249-52.

LEYSSEN, H.L. Project Vervroegd Efnde Dienstwerbend: de 55-plusger in en buiten de onderneming. Gilds Prersoneel sbel. Arbeidsvraagst. Soc. Verz. 58 (1980) 6, 9-13.

LUTHENS, E. B. HESSELS. Veiligstelling van de WUT. Ned. Juristenblad 19 (1987) $45 / 46$. $1517-22$.

UuYCKX, R.Th. Zi ektewerzulipatroon wan WA-gerechtigde handarbeiders. T. Soc. Geneesk. 51 (1973) $802-4$.

HANSVELT, J. VAH, R.C. BRUWSTIMG, B.J.M. DELEMARRE H.A. VAN DER WAAL. Een onderzoek natr oorzakelijke factoren en bijzondere kenmerken bij het langerdurend arbeidsverzuirm. dl. 1. Soc. Maandbl. Arbeld 29 ( 1974 a) 307-21.

MANSVELT, J. VAN, R.C. BRUASTING B.J.M. DELEHARRE H.A. VAN DER HAAL. Een onderzoek naw oorzakal ljke factoren on bijzondere kermerken bij het langerdurend arbetisverzulin. dl. 2. Soc. Meandbl. Arbeld 29 (1974b) $379-89$.

MARTER, W.H.W. I.A.M. GROSFELD. Inventarisering van publicaties over arbeidsongerchiktheid in de psychologle, sociologle en socilla geneesikunde: een owerzicht van dat uit het centraal documentatiesystem van de Stress Resiearch Group Nijmegien. Wijmegen, Pychol. Lab. ku, 1979. (Intern rapp. Stressgr. Wijmegen 79 a 09).

MCGOLDRICK, A.E. C.L. COOPER. Stress at the declline of one's career. In: T.A. Beehr R.S. Whagat (eds) Human stress and cognition in organizations: an integrated perspective. Met rork etc. Willey, 1985;, Pp. $177-201$.

MEIJAAN, T.F. Elasting en herstel: en begripponkedier voor het arbeidspsychollogisch onderzoek van belastingseffectem. In: $8 . G$. Deelman \& G. Mulder (red.) Bijdragen aan de experinentel gerontologie on het onderzoek nar mentale belasting en stress. Lisse etc. " swets zeitlinger, 1988. Pp. 173-94.

MELTIINEN, 0.5 . Theoretical epidemiology: principles of occurrence research in medicine. New York etc., Hilley, 1985. 
MINISTER IE VAW SOCIALE ZAKEM EN WERIKGELEGEMHElo. Hoofdli jnen nieum stelsel sociale zekerhelld. Info $1348,4-1-1987$.

MINISTERIE WAM SOCIALE ZAKEM EN MERKGELEGENHEID. Financiele note socialle zekerheld 1989. si-Graverhage, Ministerie van Sociale Zaken en werkgelegenheid, 198s. (Tweede Kamer; vergaderjaar 1988-1989, 20805 nrs 1-2).

MINISTERIE VAW HELIIJN, VOLKSGEZOHDHEIO EN CULTUUR. WOte 2000: over de ontwitkeling van gezoncheidsbeleid: feiten, beschouwingen en bellidswoornemens. "s-Gravenhage, stabtsuitgeverij, 1986.

MINISTERIE VAN WELZI JN, VOLKSGEZONOHEID EN CULTWUR. Doelgericht veranderen: ontwerp-kerndocument gezondhefidsbelleid woor de Jaren 1990-1995. Rifswifk, llinisterie van WNC "1989.

MIRKIN, B.A. Early retirement as a labor force policy: an internationel overview. Monthly Labor Rev. 110 (1987), 1933.

MOBLEY, H.H. Intermediate linkages in the relationship between job satisfactilion and employee turnover. J. Appl. Psychol. $62(1977) 2,237-40$.

MOBLEY, W.H., R.H. GRIFFETH, H.H. HAND \& B.M. MEGLINO. Review and conceptual analysis of the employee turnover process. Psychol. Bulll. 86 (1979) 493-5i22.

MORROW, P.C. Human resource planning and the older worker: developing retirement inten. tions model. J. Occup. Behav. 3 (1982) 253-61.

MORSE, D.M. \& S.H. GRAY. Egrly retirement - boon or bane?: study of three large corporations. Montclair, Allanheld \& Osmun, 1980 (Conservation of Hum. Resources ser.. 14).

NAGI, S.z. Decision criteria and the question of equity and incentives. In: H. Emanuel, E.H. de Gier P.A.B. Kalker Konijn (eds): Disability benefits: factors determining application and awards. Greenwifch/Londen, JAI Press, 1987 Pp. 157-65.

MEDERLANDSE VERENIGING VOOR ARBEIDS- EM BEDRIJFSGENEESKUWDE. Rappoint Toekomst der bedrijfsgeneeskunde in Mederland: voorstel tot toekonstige organisatie en en ontwikkelingsprogramma. T. Soc. Seneesk. 49 (1971) 928-41.

WICHOLSOW, N., T. WALL \& J. LISCHERON. The predictability of absence and propensity to leave from employees. job satisfaction and attitudes towards influence in decisionmaking. Hum. Relat. 30 (1977) 499-514.

WIIPG/THO (Heder lands Inst ituut voor Praeventieve Gezondheidszorg/TWO). Het ziekteverzuim in 1989: Overzicht op bas is van de WIPG/TWO verzuinstat istiek. Leiden. MIPG/TWO " 1990.

WIJHUIS, F. \& J. SOETERS. Werk en ziekte; een onderzoek naar afwezigheid wegens zlekte en arbeidsongeschiktheid bil 51 industriele en niet-industrilele organisaties in 2 -Limburg. Maestricht, RU Limburg, 1982.

NOOTEN, W.M. VAM \& D. ORAMISMA. Frekwentile en gemiddelde duur van verzuimgevallen op bedrififisniveau heroverwogen. (in voorberelding).

MORDQuIST, G. \&.Y. W. The joint denand for health insurance and preventive medicine. In: W. Rosett (ed.) The role of heal th insurance in the heal th services sector. Wew Yark, Wat. Bur. Econ. Res./Meale Matson Academic, 1976 Pp. 35-71.

MUnallir, J.C. Psychonetric theory. New York etc., Mcciraw-Hill, 1967 .

MVAB (Mederlandse Vereniging voor Arbelds- en Bedrijfsgeneesikunde). Doelstellingen beroepsopleiding. Leiden, CO/MVAB, 1987.

OOELL, C.E. The trend towards earlier retirement: implications for manpower and retire. ment pragram policy. Intderdiscipl. Topics Gerontol. 6 (1970) 33-42. 
OLsom-Falck, H. Early retifement in in international perspective. Int. J. Rehab. Res. 3 (1980) $215-23$.

QLsow-FRICK, H. Early retirement in an internationat perspective, II: the international study. Int. J. Rehab. Res. 8 (1985) 161-80.

PALMOME, E.8. L.K. GECRGE G.G. FILLEHBaum. Predictors of retirement. J. Gerontol. 37 (1982) $733-42$.

PARsOAS, C.K. \& C.L. HLLIH. Differentially weighting linear models in organizational research: a cross-validation comparison of four methods . Organiz. Behav. 2 Hum. Pert. 30 (1982) $289 \cdot 311$.

PERMAWENT COMITE VAM ARTSEW IN OE EEG. Chart ven bedrijfsgezondheidszorg in EurOpa. WVAB Informate 12 (1981) 3, p. 3-18.

PHILIPSEN, H. Sociale aspecten van zlekteverzuim. Wens onderneming 16 (1962) 310-22.

PHILIPSEN, H. Afwezigheld wegens ziekte: een onderzoek mear aorzaken wan verschilllen in ziekteverzuin tussen $B 3$ middelgrate bedrijwen. Leiden/Groningen, WIPG/THO/WoltersWoordhoff. 1969 Proefsehrift UVA.

PHILIPSEN, H. Enkele social-medische aspecten van de arbefidstljdverkarting en vervroegde pensionering. T. Soc. Geneesk. 57 (1979) $425-8$.

PHILIPSEN, H. R. HALFENS. Miet werken en gezondheid: een vergetijking van arbeidsongeschikten, wervroegd gepensioneerden en werklozen met werkloze mannen. Gezondheid \& Samenleving $4(1983) 161-8$.

PHILIPSEN; H. \&.K. DE VRIES-VAN DER ZEE. Generatie en ziekteverzuim I* statistische analyse. Leiden, NIPG/TNO, 1970.

POLL, K.J. Mogelijkheden voor arbeidsplatswerbetering in het scheepsonderhoud. Leiden, Bur. Hum. Arbeid TMO, 1983 (Irapp. HA 208).

PORTER, L.W. \& R.M. STEERS. Organizational, work, and personal factors in employee turnover and absenteeism. Psychol. Bull. 80 (1973) 151-76.

PORTER, L.H., R.M. STEERS, R.T. MOWOAY \& P.V. BOULIAH. Organizational commitment, job satisfaction, and turnover among psychiatric technicians. J. Appl. Psychol. 59 (1974) 5 , 603-9.

PRICE; diL. The study of turnover. Mmes, Iowa State Univ. Press, 1977.

PRICE, J.L. E.W. MUELLER. Absenteelsm and turnover of hospital employees. Greenwich/ Londen, JAI Press, 1986.

PUTTEN, P. VAN DER. Overheidssectorspectfieke arbelidsongeschiktheid. T. SOc. Gezondhelds. 61 (1983), 618-22.

PUTTEM, P. VAN DER, C.W.N. LOOMAM, P.J. VAN DER MAAS ET AL. Medische bevindingen als risicofactoren voor een pathologisch inde van het arbeidsileven. T. Soc. Gezoncheidsz. 67 (1989) $22-7$.

QUICK, J.C. J.D. QUICK. Organizational stress and preventive management. Mew York etc. MeGraw-Hill, 1984.

CuINM, J.F. Job characteristics and early retirement. Industr. Rel. 17 (1978), 315-23. 


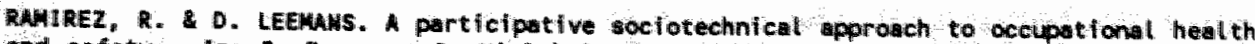

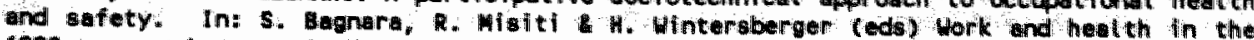

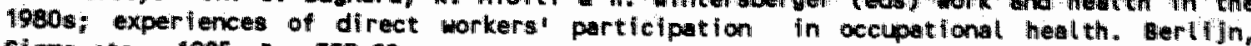
Signe etc. 1985, Pp. 353-82.

AWODEs, s. Agerelated diferences in worli attitudes and behavior: bewiew and conceptuall and ys is. Psychol. sult. $93(1983) 2,328-67$

RIJKS PSYCHOLOGISCHE DIEMST. WT-enqude. Den Haag, Rijks Psychologische Dilenst, afd. Mrbehidssociologie, 1983.

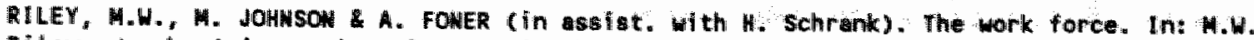
Riley et al. Aging and saciety. Vol. 3: h sociology of age stratification. New York, Russell sage, 1972 , 160-97.

ROELEVELD, M., H. KROHHOUT \& G. SUURHOND. HAO en arbeidsomstandigheden: een patiant Kon" trole-onderzoek in de grafische industrie bli het toetreden to de Who. Wagenlngen, LAMD. BOUHOGESCHOOL Vakgr. Gezoncheidsleer, 1982.

ROTHMAN, K.J. Hodern epideniology. Bostan/Toronto, Little, Brown Co, 1986.

SANTWOORT, M.H. VAH. Hederlands anderzoek naar de oudere werknemer en de penstonering: en overzicht. T. Ceront. Geriat. i3 (1982) 186-92.

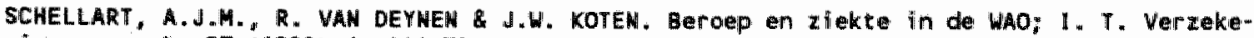
ringsgeneesk. $27(1989) 6,166-72$.

SCHELLART, A.J.M., R. VAN DEYUEN \& J.W. KOIEN. Beroep en zlekte in de WAO; II. T. Verzekerĭngsgeneesk ${ }_{\text {. }} 28(1990 \mathrm{a}) 1,6-14$.

SCHELLART, A.J.M., R. WAM DEYHEM J.U. KOTEN. Beroep en ziekte in de HAO; III. T. Werzekeringsgeneesk. 28 (1990b) $2,39-42$.

SCHWITT, H., B.W.COYLE, J. RAUSCHENBERGER \&.K. WHITE. Comparison of early retirees and non-retirees. Personnel Psychol. 32 (1979) $327-40$.

SCHAITT, N. \& J.T. McCUNE. The relationship between job attitudes and the decision to retire. Acad. of Maneg. J. 24 (1981) 4 , $795-802$.

SCHUH, A.J. The predictability of employee tenure: a review of the literature. Persontel Psychol. $20(1967) 133-52$

SHEPPARO, H.L. Mork and retïrement, In: R.H. Binstock E. Shanas (eds) Handbook of aging and the social sciences. Hew rork etc., Wan Nostrand Reinhold, 1976, Pp. 286-309.

SWULDERS, P.G.W. Bedriffskenmerken en zlekteverzuim in de jarenzestig en techtig; eten vergel ijkende studie. Leiden, NIPG/THO, 1984a. Prowachrift R.U. Limburg, 1984.

SHULDERS, P.G.W. Balans van 30 jaar zlekteverzufmonderzoek: de resultaten van 348 sudizs samengevat. Leiden, MIPG/TMO, 1984b.

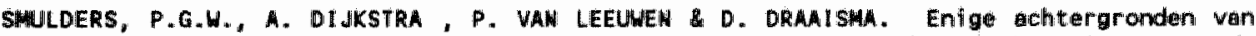
het dalend ziekteverzuin in Mederland: resultaten war een sekundaire analvse van de NIPG/TWO ziekteverzuimstatistlek. "g-Graverhage, Hîn. Soc. Zaken Werkgelegerhefd., 1983.

SOCHALE VERZEKER IHGSRAAD. Jaarwerslag 1987. Zoetermerer, SVr, 1988.

SOETERS, لt. Arbefid, organisetie en arbeidsongeschiktheid. dezondhefd 8 sament. 4 (1983) 13-22. 


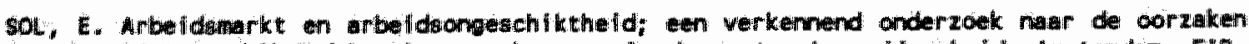

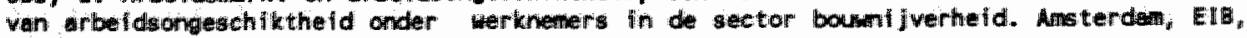
10 abiat.

SoL. E. Arbeldsongegchitutheld fin de boum. Hownerk (1983b) 74-83.

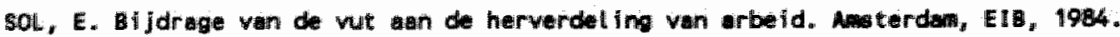

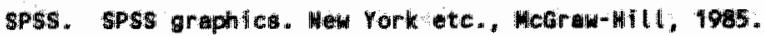

STANDIHG; 6. Labour flexibilfty and older worker warginallisation: the need for a new strategy. Int. Labour Rev. $125(1996) 329-48$.

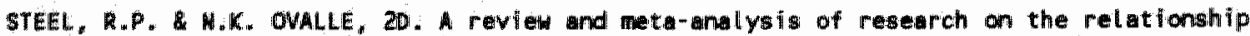
between behaviorat intentions and exploye turnower. J. Appl. Psycholl. 69 (1964) 673-86.

STELT, H, G. VAR DER H. BRUIHSHA, De reltegratie vam arbeldsongeschikten in het errbeldsproces. Soc. Mathol. Arbefd 44 (1989) 659-68.

STIERREHERG, K. Who en werkloosheid. nu Groningen, Econ. Facult., 1978.

STICHTING VAK DE AREEIO. Gezamenlijke verklaning nar aanleiding van het overlleg tussen kabinet en stichting van de Arbeld linzake de beperking wan het kort - en langcurend ziekteverzuith d.d. 31 jamuarl 1989, 's aravenhagle, Stichting van de Arbeid, 1989.

STICHTING VAH DE ARBEID. Bemeenschappel like verklaring volumebeleid arbeidsongeschiktheld. Gravenhage, stichting van de Arbeid, 1990.

STURMAW, F. Epidemiologie: theorid, methoden em toepassing. Mijmegen, Dekker Van der Vegt, 1984.

STURHAHS, F. Epidemiologie: theorie, methoden en toepassing. Wijmegen, Dekker \& Van der Vegt, 1986 .

STURMANS, F., M.C.J.M. VAH DONGEN \& G.A. ZIELWUIS. Haar een gezonde werkomgewing: epideniologie binnen de bedrijfsgezondheidszorg. Nijmegen, Dekker \&an de Vegt, 1982.

STURHAMS, F. H.A. VALKENBURG. Doelstellingen en normen van epidemiologisch onderzoek. T. Soc. Geneesk. 55 (1977) 473-9.

SUPER, D.E. The psychology of careers: an introduction to vocational development. Hew York, Harper, 1957 .

SUPER, D.E. Wocational itfe stages. In: D.G. Zytowski (ed.) Vocational behavior: reading in theory and research. Wew York etc., Holt Rinemart \& Winston, \$968, Pp. 146-147.

SHANBORH, P.G. Schaltechnileken: theorie en proktijk van achteenvoudige procedures. Ansterdion etc. Goom, 1982.

SYAL, S.L. L.F. BERKMAM. Social class, susceptibility and Bickness. Aner. J. Epideniol. $(1976) 104,1-8$.

TAPPEL, H. HERA. Het werkt anders: een overzicht van matregeten tegen veet voorkomende problemen met de kwalitit van arbelisplatsen in de industrife. Voorburg, Directoraat-Generial wan de Arbeld, 1986 (rapport $s$ 18).

TAYLOR, P.J. Stress in relation to prengture medical retirenent, J. Soc. occup. Hed. 29 $(1979) 95-101$.

THIJSSEN, L.J.M. De ontwkkeling van het arbeidsongeschiktheidsvolume bij de overheid. soc. Marandbl. Arbeid $45(1990) 5,303-11$. 


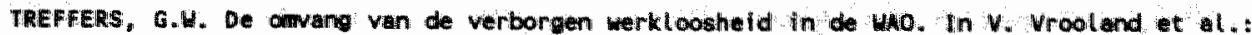

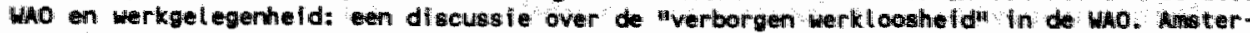
disn, stichting CCOZ, 1980. Pp. 16-20.

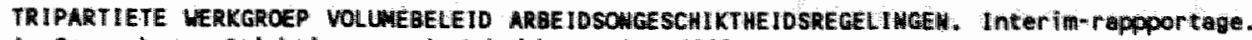
"s-Grovenhage, Stichting van de Mrbeid, october 1909.

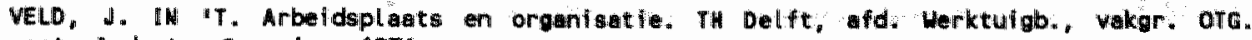
sect. Industr. Organis: 1976.

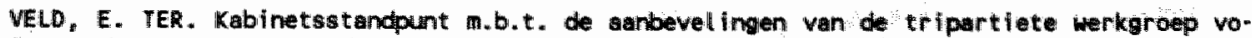
line arbeldsongeschiktheidsregelingen: brief aen de stich ing van de Arbeid van de Stavessecretaris van Sociole Zaken en Werkgelegenheld: Is-graverhage, Ministerie van Socilate Zaken en Werkgelegenheid, 6 mant $19 \% 0$.

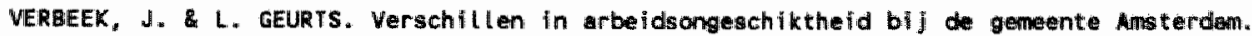
T. Soc. Gezondiveidsz. 65 (1987) 562-6.

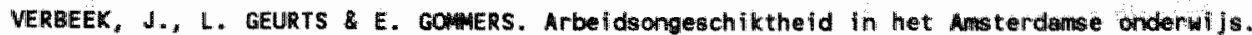
T. Soc. Gezondheidsz. 67 (1989) 161-4.

VERBOWD WAN NEDERLANOSE ONOERHEMINGEN. Voorstel werkgevers tot indamen snelle groeil alahtal arbeidsongeschilkten. "s-Gravenhage, VNo, 1990 (extra witgave Weekblad ondermening, 28 juni 1990).

VISSER, R.S.H., J.R. VAN VLIET-MULDER, A. EVIERS \&. TER LAAK: Documentatie van tests en

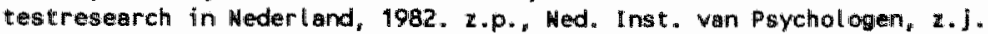

VOS, H.H. DE. Het meten van werkorientaties: een vergelijking van verschillende techni aken voor het meten van houdingen. Proefschrift R.U. Groningen, 1980

VIIES-WAW DER ZEE, A.K. DE. Gemeratie en ziekteverzuim II : veel en weinig verzuimers. LeIden, HIPG/TWO, 1973.

WRIJHOF, B.J. De ontwikkel ing van het verzuim in Nederland: een evaluatie van de vergelijkbaarheid en de bruikbaarheid van de beschikbere cijfers. unserdan, stichting ccoz, 1986.

WRI JHOF, B. J. Ziekteverzuilmerschillen: toewal of niet? De betrouwbaiaheld en het onderscheidingswermogen van $z$ iekteverzuimcijfers in relatie tot de groepsomang. Amsterdan, stichting $\operatorname{cco}, 1987$.

VRooh, W.H. Work and motiwation. Hew York etc., Hilley, 1964.

VROOHAM, J.C. \& A.A.H. DE KEAP. Arbeidsongeschilktheid: vollume en wbeidsmarkt. Economisch Stat istische Berichten $75(1990), 942-3$.

WALLIS, W.A. H.V. ROBERTS. Statistics; new approach. 2 "P., The Free Presis of Glencoe, 1963.

WE ITZ, J. R.C. HUCKOLS. Job setisfaction ond job survivall. J. Appl. Poychol. 39 (1955), $294-300$.

HET OP DE ARBEJOSONGESCHIKTHEIDSVERZEKER MG, Wet van 18 februari 1966 (5tb. 84) inzake de arbeidsongeschik theidswerzelkering.

MICKstRdi, G. Drabbacks of clínical diagnoses in epidemiologic research on work-related

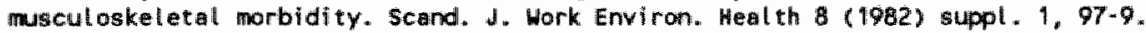

WIERSMA, D. Psychosocite Hgtress" en langdurige arbeidsongeschiktheid. Groningen, 1979. Proefschrift R.U. Groningen, 1979. 


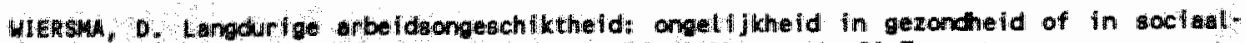
conomi sche om tandigheden. 1. soc. Geneesk. 58 (1980) suppl. 91-7.

WILCINS, A. 0.8. MDNS. Changes in the healthfulness of life of the elderly population: an enplificat approach. Rev. Epidemioll. et Santé Publ. 35 (1987) 225-35.

WILLES, J.H.B.M. overwegingen blj ten proventilef beleid in de sociale verzekeringsgeneieskunde. $T$. Verzelkeringsgeneest. 27 (1989) $5,139-44$.

WILLIGE, G. VAN DER, H. songI, R. KLUVER ET AL. Gedrag en gezonoheid: een interactionete benadering Gezondheld \& senentewing 4 (1983) 32-41.

WINTER, C.R. OE Inclidence of disability in supervis.ory and non supervisory enqlioyees. In: c. Hogstedt $C$. Reuterwall (eds) Prosress in occupetional epidemiology. Ansterdan etc., Excerpta Mediea, 1988, Pp. 329-33.

WIHTER, C.R, DE, F.H.O. MARCELISSEM D.J. VAH PUTTEN. De vragenlijst voor periadiek bedriffisgezondhe idgakundig onderzoek IW: kwallteit en structuur. T. Soc. Gezondheidsz. Go $(1988) 143-7$.

WOLOZIN, H. Earlifer retirenent and the older worker. J. Econom. Issues $15(1981) 477-87$.

WHO (WORLD HEALTH ORGAMIZATION). International clasifification of impairments, disabilities, and handicaps. Geneve, WHO, 1980.

ZAAL, M.d, VAM. Hotitles Inzake arbeidsongeschiktheid. T. Psychiatrie $16(1974)$ 183-9.

ZEE, J. VAN DER. De yraag naar diensten van de huisarts. Maastricht, 1982. Proefschrift RU Limburg, 1982.

ZIEKTEWET; wet van 5 juni" 1913 (Stb. 204) tot regelling van de arbeidersziekteverzekering.

$2 I J L$ P.H. VAN \& C. DE WOLF. Het begrip "passende arbeid" in de sociale zekerheidsregellingen. Soc. Maandbl. Arbeid 31 (1976) $650-9$. 
BIJLAGEN

Bijlage 1

Vragenlijst Arbeid en Gezondheid (VAG)

pagina

Bijlage 2

Vragenlijst Arbeid en Gezondheid (VAG korte versie)

Bijlage 3

Samenstelling somscores lange VAG, vragen kort aangeduid, aantal vragen aangegeven met $\mathrm{m}$

Bijlage 4

Splitsing VAG-kort in twee indices: Conditie $_{\mathrm{k}}$ en Werksituatie ${ }_{\mathrm{k}}$, items kort aangegeven; aantal vragen aangegeven met m

Bijlage 5

Ligging van de grenswaarden binnen de verklarende variabelen; aangegeven zijn de cumulatieve percentages en de in de tekst gebruikte aanduiding van de grenzen $(20 / 80$ etc. $)$

Bijlage 6

Sensitiviteit en specificiteit van de IDR's, lange VAG bij arbeidsongeschiktheid (mannelijke werknemers)

Bijlage 7

Sensitiviteit en specificiteit van de IDR's, lange VAG bij vervroegd uittreden (mannelijke werknemers)

Bijlage 8

Sensitiviteit en specificiteit van de IDR's, lange $V A G$ bij ontslagname (mannelijke en vrouwelijk werknemers)

Bijlage 9

Sensitiviteit/specificiteit arbeidsongeschiktheid, Conditie $_{x}$ en Werksituatie ${ }_{k}$

Bijlage 10

Sensitiviteit/specificiteit VUT, Conditie $_{\mathrm{k}}$ en Werksituatie $\mathrm{k}_{\mathrm{k}}$

Bijlage 11

Sensitiviteit/specificiteit ontslagname, Conditie $_{k}$ en Werksituatie ${ }_{k}$ 
$\therefore \quad 3$

8 


\section{Biliage 1}

VRAGENLIJST ARBEID EN GEZONDHEID (VAG)

Een onderzoek naar gezondheid, werk en werkomstandigheden 
Doel van deze enquete is inzicht te kriggen hoe werknemer hun eigen gezondheid, werk en werkomstandigheden ervaren, on zo een bijdrage te leveren an de kwaliteit van de werksituatie.

De vragenlijst bestat uit de volgende hoofastukken:

1. funktie

2. inspanning

3. fysieke werkomstandigheden

4. gezonaheid

5. leiding en kollega's

6. organisatie van het werk

7. voorzieningen

8. werk-privé

9. werkkring

10. extra vragen

11. slot

- Zonodig kunt $U$ in hoofastuk 10 angeven of en met wie $U$ over problemen in het werk wilt praten.

Alleen de uitkomsten van groepen werknemers warden verwerkt in een algemeen rapport, warin geen namen en gegevens wan afzonderlijke personen worden genoemd.

- Het samenvattende verslag worat an iedere werknemer toegezonden. terwijl de uitgebreide gegevens voor iedereen ter inzage zulden $z i j \mathrm{n}$

Alle individuele gegevens zullen vertrouwelijk worden behandeld: Uw ingevulde vragenlijst gat alleen nat het NIPG/TNO in Leiden en nergens anders heen.

- Ieders deelname is zeer belangrijk voor het slagen van het onderzoek, max is vrijwillig. 
- Deze vragenlijst gaat over Uw gezondheid, Uw werk en Uw werkomstandigheden. Het gat er bij het invullen om, dat $U$ de knelgunten en plezierige kanten van uw werk zoals die zelf ziet zo goed mogelijk nat voren lat komen.

- Bij elke vraag kunt U aangeven wat U van een bepaald aspekt van Uw gezondheid, werk of werkituatie vindt.

WOORBEELD 1: Vindt U een personeelsvereniging zinvol?

Indien $U$ vindt dat een personeelsvereniging zinval is, kruis dan als volgt aan:

$$
\text { nee }(\text {, ja }(x)
$$

- Bij enkele vragen hoort een vervolgvraag, waarbij $u$ op het volgende dient te letten.

YOORBEELD 2 : zit $U$ in een sportvereniging?

Indien $U$ wel in een sportvereniging $z i t$, kruis dan als volgt aan:

$$
\text { nee } \begin{array}{cc}
1 & 3 a(x) \\
1 & 3
\end{array}
$$

\section{Zo $2 a$}

Vindt U dat de sportvereniging goed werkt?

Indien $U$ van mening bent dat de sportvereniging wel goed werkt, kruis dan als wolgt aan:

$$
\text { nee }\left(\begin{array}{cc}
1 & \text { ja } \\
1 & (x) \\
2
\end{array}\right.
$$


VOORBEEID 3: 2 it $U$ in een sportvereniging?

Indien $U$ niet in en sportvereniging zit. kruis dan als volgt aan:

nee $(x)$ ja $\left(\begin{array}{l}2 \\ 1\end{array}\right.$

Zo ja

vindt $U$ dat de sportvereniging goed werkt?

Ondat U de eerste vraag met "nee" beantwoordde. hoeft deze vervolguraag niet te beantwoorden.

$$
\text { nee ( ) ja }\left(\begin{array}{ccc}
1 \\
1
\end{array}\right.
$$

- Wilt U de vragen goed lezen, let bijvoorbeeld op de woorden weleens of vaak, meestal of veel.

- Als een vraag moeilijk in te vullen is, probeer dan toch het meest passende antwoord aan te kruisen. Als $\mathrm{U}$ echt geen antwoord kunt of wilt geven, of wanneer de vraag voor U niet van toepassing is " lat U dan het cirkeltje open; wilt o niets veranderen an de voorgedrukte antwoorden.

- Aan het eind van ieder hoofdstuk is ex ruimte om opmerkingen te maken of ideeen voor verbetering te geven: 
- De inviltija is gemiddeld ongeveer ển uur, mar vult u de vragenlijst rustig in uw eigen tampo in. 
1. EUNKTIE

Welke runktie heeft U?

- Wilt U UW funktie eventueel hieronder kort toellichten?

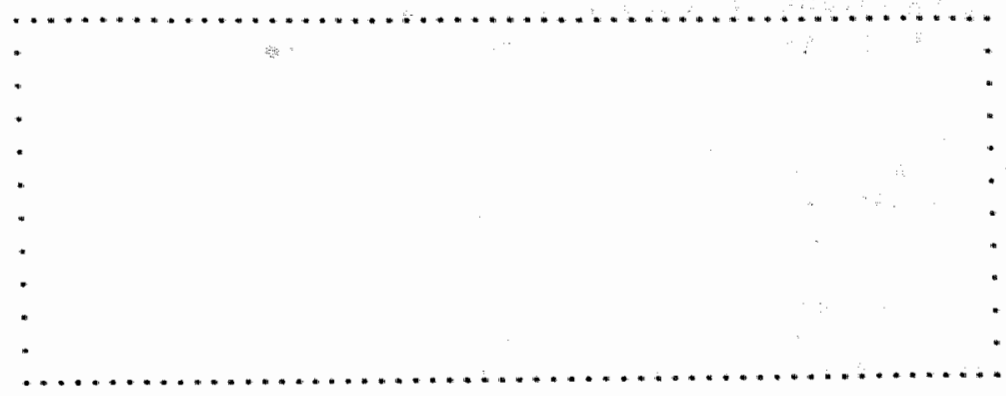


- werken aar produkter

- werken a an praduktimachines of -installaties

- technisch onderhoud reparatiewerk verichten

- beproeven, tosten, kontroleren van produkten of materialen

- vervoeren, verplatsen van personen os goederen

- regelen van vervoersstromen

- werkzamheden met of rondom de computer doen

- sekretariatswerk doen

- archief-, dokumentatiewerk verrichten

- boekhouden, financiele administratie voeren

- allerhande administratieve werkzaamheden doen

- beheren

- beleid voorbereiden

- beleid vormen

- dagelijks letding geven

- management

- organiseren en plannen

- ontwerpen van werkmethoden produkten, programma's

- huishoudelijk werk doen

- schoonmaken, reinigen

- ander werk doen, nl. 
- dingen bewerken met de hand, met handgereedschap

- eigenhandig besturen wan een bewerkingsmachine

- bewaken of bijsturen van een fabrikageproces

- instellen of afstelien van machines of apparaten

- produkten bijstellen of afregelen

- kontroles uitwoeren

- sorteren

- inpakken of verpakken

- dingen verplaatsen met hand- of lichaamskracht

- eigenhandig besturen van een transportmiddel

- informatie opsporen, zoeken

- informatie verzamelen, meten

- informatie bruikbaar maken, ordenen, koderen of dekoderen

- informatie beoordelen of selekteren

- berekeningen maken

- schriftelijk verslag doen

- mondeling verslag doen

WILT U VAN DE AANGEKRUISTE MKTIVITEITEN DE MEEST WOORKOMENDE HIERBOVEN AANKRUISEN? 
- Welk onderwijs hebt U genoten? (s.v.p. ển rondje aankruisen en wel dat wat het meest met uw niveau van opleiding overeenkomt)

- Lager onderwijs

- Lager algemeen vormend of lager beroepsonderwijs

- midelbaar onderwijs of middelbaar beroepsonderwijs

- hoger beroepsonderwijs

- akademisch onderwijs

- Winneer heeft $U$ voor het laatst, in verband met Uw werk, een opleiding of kursus gevolgd?

- nooit

- nog bezig

- 1-2 jaar geleden

- 3-4 jaar geleden

- 5-10 jaar geleden

- 11 jaar of langer geleden

- Heeft U voor dit werk genaeg schaling?

- Hoeveel uur per week werkt U gemiddeld voor dit bedrijf of deze organisatie (overwerk meegerekend)?

.... uur per week

- In wat voor soort dienst werkt U officieel? (ến aankruisen)

- dagdienst

- andere dienst: dienst met nachtdienst

- andere dienst: dienst zonder nachtdienst

- Vindt $v$ dit scort dienst gunstig?

- Werkt u geregeld over voor dit bedrijf of neemt $U$ geregeld werk mee naar huis?

zo ja

- Vindt U overwerken voor Uzelf gunstig? 
Kunt $U$ op ieder moment als $U$ dat nodig vindt even het werk onderbreken?

Heeft $U$ in Ww werk voldoende afwisseling?

Heeft $U$ tijdens het werk voldoende kontakten met andieren?

Is Uw werk meestal boeiend?

Heeft U meestal plezier in Uw werk?

Gat de werktijd meestal snel voorbif?

Vindt $\mathrm{U}$ het werk te eenvoudig?

- Vindt U het werk te moeilijk? nee (? ja 1 ( )

nee ( ) ja ( )

nee ( y a i j

nee $\left(\begin{array}{ccc}2 & \text { ja } \\ 2 & \end{array}\right.$

nee ( ) ya ( )

nee ( ) ja ( )

nee ( ) ja 1 '

nee $\left(\begin{array}{c}1 \\ 1\end{array}\right.$

- Indien U verder nog opmerkingen of ideeen voor verbetering hebt naar aanleiding van het hoofdstuk 'FUNKIE', wilt U deze dam. hieronder toelichten. 
2. INSPANNING

- Is Uw werk lichamelijk erg inspanrend?

nee $\begin{array}{ccc}(1) & \text { ja } & (j) \\ 1 & \end{array}$

- Is Uw werk geestelijk erg inspannend?

nee ( ) 3a ( )

nee $(1)$ ja $($ )

nee ( ) ja 1 ; nee ( $)$ ia (

- Is het werk voor U valk te vermoeiend?

nee ( ) ja $\left(\begin{array}{l}1 \\ 2\end{array}\right.$ drukte van het werk?

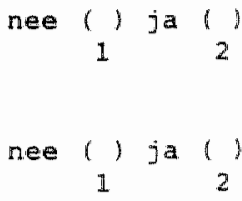

- Heeft U in Uw werk:

- moeite met bukken of werken in gebogen Lichaamshovaing

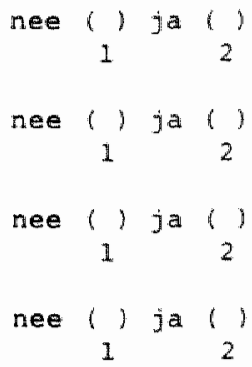

- moeite met sitan 
Heeft U in UW werk:

- moeite met lopen

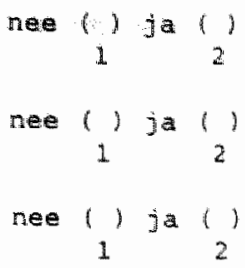

- moeite met traplopen

- moeite met werken in een ongemakkelijke lichaamshouding (denk bijv, an werkem in liggende houding, gehurkt of geknield werken, net de handen boven de macht werken. enz.)

- Meeft U in Uw werk:

- moeite met ingespannen kijken

- moeite met scherp luisteren

- moeite met 0 te koncentreren

- moeite met onthouden

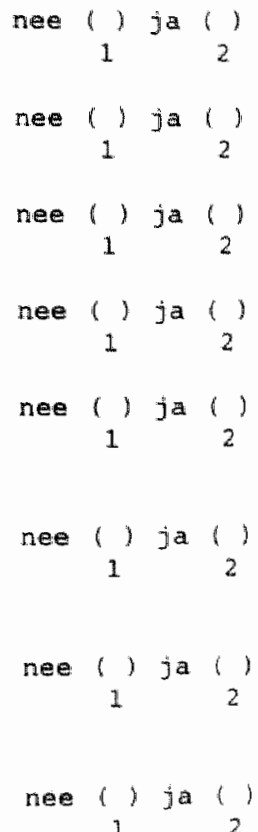


- Indien $U$ verder nog opmerkingen of ideeen voor verbeteringen heeft naar aanleiding van het hoofdstuk "INSPAMNING', wilt $U$ deze dan hieronder toelichten? 
- Werkt $U$ meestal binnen, meestal in de buitenlucht of afwisselend binnen en in de buiterilucht?

- meestal binner

- meestal in de buitenlucht

(1) 1

- afwisselend binnen en in de buitenlucht

1,2

( ) 3

Heeft $\mathrm{U}$ een eigen werkplek?

nee $\left(\begin{array}{ccc}(1) & \text { ja } & (1) \\ 1 & 2\end{array}\right.$

- Is de plaats waar U meestal werkt goed ingericht?

nee $\left(\begin{array}{l}1 \\ 2\end{array}\right.$ ja 1 ,

- Heeft $U$ in het werk:

- veel hinder van kou

nee ( ) ja ( )

- veel hinder van warmte

nee $\left(\begin{array}{ccc}1 \\ 1\end{array}\right.$

- veel hinder van wisseling van temperatuur

nee ( ) ja ( )

Heeft $U$ in het werk:

- veel hinder van droge lucht

$\begin{array}{cccc}\text { nee ( ) ja } & (\text { ) } \\ 1 & & 2 \\ \text { nee } & (1) & \text { ja } & (?) \\ 1 & & 2 \\ \text { nee ( ) ja } & (\text { ) } \\ & 1 & & 2 \\ \text { nee ( ) ja } & (\text { ) } \\ 1 & & 2\end{array}$

- veel hinder van gebrek aan frisse lucht 
- Heeft $\mathrm{U}$ in het werk:

- veel hinder van lawaai

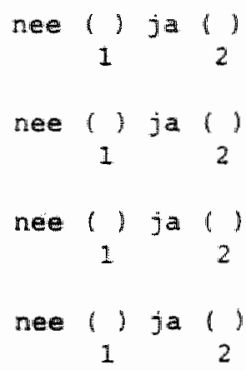

nee ( ) ja ()

nee ( ) ja ( )

1

nee () ja ( )

- veel hinder van mechanische trillingen, schokken

- veel hindex van onvoldoende verlichting

- veel hinder van ongeschikte verlichting, verblinding, reflektie

- Heeft o in het werk:

- veel hinder van damp, nevel, gas

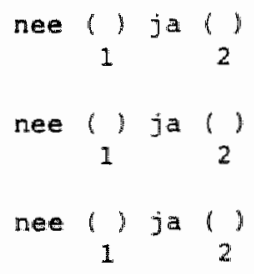

nee ( ) ja ( )

1

2

nee ( ) ja ( )

1

- veel hinder van rook

- vel hinder van stank

- Heeft $U$ in het werk:

- veel hinder van stof

nee ( ja ( )

- veel hinder van vuil, smeer

nee () ja ()

Indien $U$-opmerkingen of ideeen voor verbeteringen heeft naar anleiding van het hoofdstuk 'FYSIEKE WERKOMSTANDIGHEDEN', wit U deze dan hieronder toelichten? 
4. GEZONDHEID

- Heeft U de laatste tijd gezonaheidsklachten?

nee (y) ya

Wordt $U$ in Uw werk geregela gehinderd doordat U zich niet in orde voelt?

nee ( ) ja $\{$ )

$\underline{20} \quad 2 a$

- Wilt U hieronder toelichten in hoeverre u zich niet in orde voelt?

Heeft $U$ gezondheidsklachten warvan $U$ denkt dat ze door het werk kamen?

nee $\left(\begin{array}{l}1 \\ 1\end{array}\right.$

$\underline{z a} j a$

- wilt $\mathrm{U}$ hieronder toelichten welke gezondheidsklachten door het werk komen?

- Heeft U weleens last van benauwdheid, kortademigheid? new ( ) ja 1 ( )

- Heeft U weleens hartklachten? nee (1) ja ()

- Heeft $U$ weleens magklachten? nee (1) ja ( ) Heeft $U$ weleens buikklachten nee ( ) Ja ( ) 
- Heeft U geregela:

- klachten over armen, handen

nee () ja (1)

1

2

- klachten over benen, voeten

nee (1) ja 1

1

- Klachten over schouders, nek

nee () ja 13

I

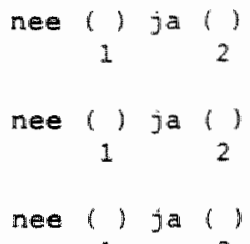

Heeft U klachten door overgev
bepalde stoffen op het werk?

$20 j a$

- Wilt U dan hieronder toelichten voor welke stoffen op net werk $U$ overgevoeling bent?

- Heeft y vak last van tranende, vermoeide of pijnlijke ogen?

- Heet v (eventueel met brill vaak problemen met scherp zien?

- Heeft U vak moeite met horen?

- Heeft $\mathrm{U}$ welens iast van duizelingen?

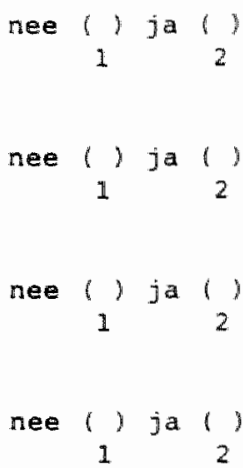


Bent $U$ raak vergeetachtig?

Heeft $\mathrm{U}$ geregeld hoofdpijn?

Woelt U zich vaak gespannen?

Bent U dikwijls prikkelbaar?

Bent U vaak nerveus?

Voelt U zich raak gejaagd?

Bent U vaak moedeloos?

staat 0 na het slapen geregeld met een moe gevoel op?

slaapt U meestal slecht?

Kont U valk slaap te kort?

Gebruikt u geregeld medicijnen?

2o ja

- wht u hieronder toelichten welke medicijnen u regelmatig gebruikt? 
- Bent $U$ de afgelopen zes manden met een klacht naar en arts gewest?

Wordt $U$ nu behandeld voor hoge bloeddruk?

Wordt U wir behandela voor andere hart-, vataandoeningen?

- Wordt U nu behandeld voor longaandoeningen?

- Wordt U nu behandeld voor aandoeningen van organen in borst of buik?

- Wordt u nu behandeld yoor overgevoeligheid (allergie)?

- Wordt U nu behandeld voor rugaandoeningen?

- Wordt u nu behandeld voor andere spier-, gewrichtsaandoeningen?

- Wordt U nu behandeld voor lets anders? nee 1 ) ja 11

nee $\frac{1}{1}$ ja $(1)$

nee (1) ja $(1)$

nee $(1)$ ja 1 ( )

nee ( ja $($ )

1

nee ( ) ja ( )

nee ()$j a(1)$

1

nee ( ) ja ( )

nee ( ) ja ( )

1

zo ja

- Wilt u hieronder toelichten voor welke andere aandoening U nu behandeld wordt?

Bent $U$ de afgelopen zes maanden weleens van Uw werk thuis gebleven wegens ziekte of ongeval? nee $(1 j a()$ 1 
- Indien U opmerkingen heeft raar anleiding van het hoofdstuk 'GEZONDHEID', wilt deze dan hieronder toilichten? 
5. LETOLNG EN KOLLEGA'S

- Vindt $U$ de onderlinge sfeer meestal goed op het werk? nee ( ) ja (')

- Werkt U geregeld met wisselende kollega"s?

nee ( ) ja ( )

- Kunt U, als het nodig is in Uw werk, een beroep doen op ển of meer kollega's?

nee ( ) ja ( )

nee ( ) ja ( )

Ergert $\mathrm{U}$ zich vak aan anderen op het werk?

nee ( ) ja $(2)$

Werkt $U$ onder telkens wisselende leidinggevenden?

nee $\left(\begin{array}{c}\text { ( ) ja } \\ 2\end{array}\right.$

nee ( ) ja ( )

[w werk?

- Houdt de direkte leiding voldoende rekening met wat $U$ zegt?

nee (') ja ( )

nee $\left(\begin{array}{c}2 \\ 2\end{array}\right.$ ja (

steund in Uw werk?

- Wordt het werk doorgaans billijk verdeeld tussen U en de anderen?

mee ( ) ja i:

nee ( ) ja ( )

- Wordt U in Uw werk te veel op de vingers gekeken?"

nee $($ ) ja $(3)$

Wordt $U$ voldoende op de hoogte gehouden
in Uw bedrijf of organisatie afspeelt?

2 
- Indien U opmerkingen of ideeen voor verbeceringen heb naar aanleiding van het hoofdstuk "LEIDING EN KOLLEGA ' $S$ " "Wilt 0 deze dan hieronder toelichten? 
6. ORGAHISATE VAN HET WERK

- Is het werk doorgaans goed georganiseerd?

nee $\left(\begin{array}{ccc}1 & \text { ja } \\ 2 & 1\end{array}\right.$

- kunt U voldoende overleggen over Uw werk?

nee (j) ja

nee $(1)$ ja $(1)$

$20 \quad 19$

- Lopen deze werkbesprekingen over het algemeen goed?

nee ${ }_{2}$ Ja $(1)$

nee $(1)$ ja $(\mathrm{I})$

Zo ja

- Lopen deze vergaderingen over het algemeen goed?

nee $(j$ ja $(y)$

nee ( ) ja ( )

werkopdracht?

1

$20 \quad$ ja

- Loopt het samenwerken over het algemeen goed?

nee $\left(\begin{array}{ccc}1 & \text { ja } & 1 \\ 2 & 1\end{array}\right.$

nee $(1)$ ja

pen waamere $u$ the maken heeft in het algemeen goed?

nee $(1)$ ja 1

situates

nee $($ ) ja 4

nee ( ) ja ( )

Heft $U$ wak verschil van mening over de kwaliteit van Uw werk?

- wordt U in het werk geregela gehinderd door gebreken in het werk van anderen?

nee ( ) ja $(1)$ 1 
- Wordt vw wex vaak bemoeilijkt dook afwezigheid wan anderen? nee: $(-)$ ja $\frac{1}{2}$

nee () ja ( )

2

1

(hulp)middelen? (Denk an gereedschap, machines, apparatuur, kommunikatie- en transportmidaelen enz.)

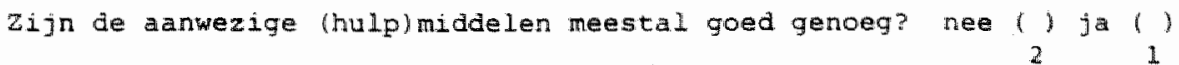

Kunt $U$ in het werk meestal beschikken over voldoende gegevens en informatie?

nee $\left(\begin{array}{ccc}1 \\ 2\end{array}\right.$

nee $\begin{array}{ccc}1 \\ 2\end{array}\left(\begin{array}{l}\text { ja } \\ 1\end{array}\right.$

Indien $U$ opmerkigen of ideeen voor verbeteringen hebt war anteiding van het woofdstuk "ORGANISATIE VAN HET WERK', Wilt $\mathrm{U}$ deze dan hieronder toelichten? 


\section{VOORZIENTMGEN}

- Kunt $U$ in Uw bedrijt bij lemand terecht woor goede hulp bif problemen van Uzelf of van anderen?

nee ( ja () 1

- Zijn Uw ervaringen met de afdeling Personeelszaken gunstig?

$-j a$

- nee

- geen ervaring

111

( $) 2$

(1) 3

- Wit U eventuel hieronder IW ervaringen toelichten?

- Zijn Uw ervaringen met de Bedrijfsgeneeskundige Dienst gunstig?

$-j a$

( 11

- nee

$1 \longdiv { 2 }$

- geen ervaring

( ) 3

- Wilt $U$ eventueel Uw ervaringen hieronder toelichten?

Zijn Uw ervaringen met het Bedrijfsmatschappelijk Wexk gunstig?

- ja

- nee

- geen ervaring

- Wilt U eventueel Uw ervaringen hieronder toelichten? 
Zo Ja

- wilt 0 hierondex toelichten welke gevaarlijke stoffen er in Wwerk zijn?

Vexeist Uw werk dat $U$ voor Uw eigen veiligheid beschermingsmiddelen gebruikt?

zo ja

- Zijn deze persoonlijke beschermingsmiddelen in orde?

- Vindt $u$ dat het verder in orde is met de velligheid in het werk? (Denk bijv. aan voldoende veiligheidsvoorzieningen op gevaarlijke plekken waar $U$ komt, warschuwingssignalen, vluchtwegen, instrukties, ...........

\section{Indien neen}

- Wilt U hieronder toelichten wat niet in orde is met de veiligheid in het werk?

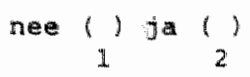

$$
\text { nee ( ) ja ( ) }
$$

nee () ja ( ) 
- Zijn Uw ervaringen met de veiligheidsdienst gunstig?

$-j a$

- nee

- geen ervaring

(1)

112

1) 3

- Wilt U eventueel hieronder Uw ervaringen toelichten?

- Vereist Uw werk speciale werkkleding?

nee () ja ( y

Zo ja

- Is deze werkkleding in orde?

$$
\begin{aligned}
& \text { nee ( ) ja ( ) } \\
& \text { nee ( ) ja ( ) }
\end{aligned}
$$
heid) in orde?

- zijn de kantinevoorzieningen (ruimte, drank en eten) in orde?

nee $($ ) ja $($ )

- Indien u opmerkingen of ideeen voor verbeteringen heeft naax anleiding van het hoofdstuk 'vOORzIENINGEN" wilt v deze dan hieronder toelichten? 
8. WERK-PRIVE

- Vindt U het reizen tussen huis en werk bezwaarlijk? nee ( ) ja ( )

Zijn er omstandigheden IN Uw werk die een ongunstige invloed hebben of Uw priveleven?

nee ( ) ja 1 ( )

Zijn er omstandigheden BUITEN Uw werksituatie die U zo bezighouden dat tw werk eronder lijat?

Indien $U$ opmerkingen of ideeen voor verbeteringen hebt naar aanleiding van het hoofdstuk "WERK-PRIVE", wilt U deze dan hieronder toelichten? 


\section{WEFKKRING}

- Voelt 0 zich in dit bedrijf voldoende gewaardeerd?

nee $\left(\begin{array}{ccc}1 & j a \\ 2 & 1\end{array}\right.$

- Hordt dit bedrijt goed geleid?

nee ( 3 ja $(1)$

- Werkt de ondernemingsrada goed?

nee $\left(C_{2}\right)$ ja $(1)$

- Is dit woor $U$ een goed bedriff om in te werken?

nee ( ) ja 1 ( )

nee $\left(\begin{array}{ccc}1 \\ 2\end{array}\right.$

nee ()$\left._{2}\right)$ ja $(1)$

- Wordt $\mathrm{U}$ in dit bedrije billijk behandeld?

nee ( ) ja ( )

dat U doet?

nee $\left(\begin{array}{ccc}2 & \text { ja } & 1 \\ 2 & 1\end{array}\right.$

nee ( ) ja ( )

veranderingen woor Uzelf in het werk?

nee $($ ) ja ( )

Donkt $U$ er de laatste tijd over om ander werk te zoeken (binnen of buiten het bedrijf)? 
Indien $U$ opmerkingen of ideeen voor verbeterigen heeft naar aanleiding van het hoofdstuk "WERKKRIMG" "wilt U dan deze hieronder toelichten? 
10. EXTRA VRAGEN 
11. SLOT

Welke vindt $\mathrm{u}$ de gunstigste kanten van bw werk in dit bedrijf?

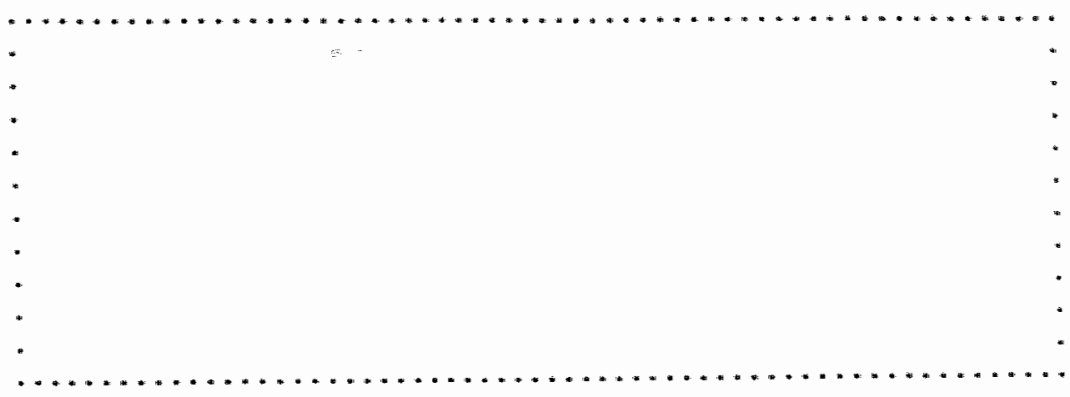

Welke vindt $U$ de ongunstigste kanten van Uw werk in dit bedrije?

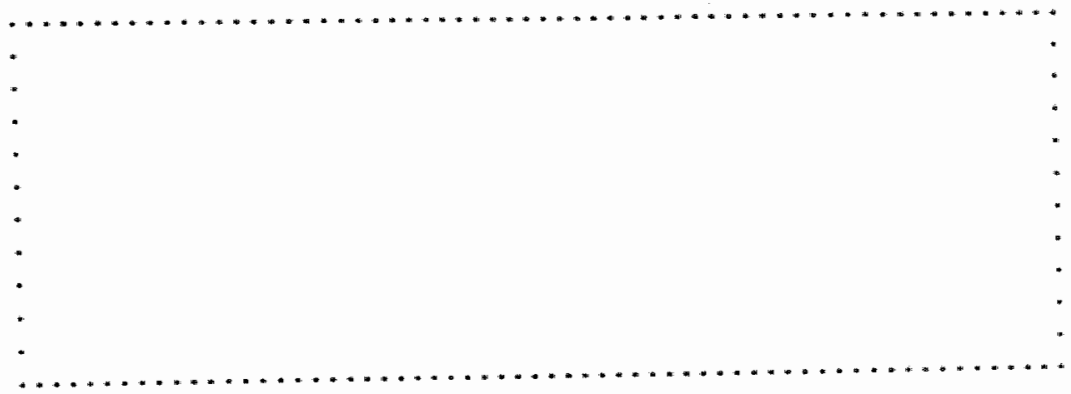

Al met $a 1$, vindt $U$ nu zelf dat $U$ goed, redelijk, matig of niet goed zit met Uw werk?

- goed

- redelijk

- matig

- niet goed 

VRAGENLIJST ARBEID EN GEZONDHEID

(VAG, korte versie)

Een onderzoek naar gezondheid, werk en werkomstandigheden 


A Bent U man of vrouw?

B Wat is Uw geboorte jaar?

C. Bent U leidinggevende?

D Wat voor scholing hebt $U$ ?

E Werkt U meestal binnen, buiten of af wisselend binnen en buiten?
19.

$2-3$

ja

() 1

4

nee

lager onderwijs

() 1

lager algemeen vormend of lager beroepsonderwijs

() 2

middelbaar onderwijs of middelbaar beroepsonderwijs hoger beroepsonderwijs of meer
() 3

() 4

F Wat woor soort dienst heeft $U$ ?

dagdienst zonder meer

(): 1

een ander soort dienst

( ) 2

S.w.p. doorgaan op de volgende bladzijide. 
Kolom

1 Heeft U voor uw werk genoeg scholing?

ja

nee

2 Heeft $U$ in $U w$ werk voldoende af wisseling?

() 1 (1) 28

3 Is Uw werk meestal boeiend?

() 1 ( ) $2 \quad 9$

4 Heeft U meestal plezier in Uw werk?

() 1 ( ) 210

5 Vindt $U$ het werk te eenwoudig?

(1) 1 () $2 \quad 11$

() 1

() 212

6 Is Uw werk lichamelijk erg inspannend?

() 2 () 113

7 Is Uw werk geestelijk erg inspannend?

() 2 () 114

8 Werkt $U$ geregeld onder tijdsdruk?

() 2 () 115

9 Is het werk vaak te vermoeiend?

(1) 2

() 116

10 Heeft $U$ geregeld problemen met het tempo of de drukte van thet werk?

(1) 2 (1) 117

11 Zou $U$ het in het werk eigenlijk kalmer aan moeten doen? ()

12 Hebt $U$ de laatste tijd gezondheidsklachten?

() 2 () 119

13 Voelt U zich valk gespannen?

() 2 () 120

14 Bent $U$ vaak nerveus?

() 2 () 121

15 Voelt $U$ zich vaak gejaagd?

() 2 () 1 22

16 Bent U vaak moedeloos?

17 Gebruikt U geregeld medicijnen?

(a) 2 () 123

18 Bent $U$ de afgelopen zes maanden nar de dokter geweest?() 2

() 2 () 124

19 Bent $U$ nu onder behandeling van een arts?

() 2

(1) 125

20 Bent $U$ de afgelopen zes maanden wel eens van $U$ w werk thuisgebleven wegens ziekte of ongeval?

(1) 2 (1) 1

21 Heeft $U$ in het werk veel hinder van wisseling in temperatuur?

$\begin{array}{lllll}\text { () } & 2 & \text { () } & 1 & 28 \\ \text { () } & 2 & (0 & 1 & 29 \\ \text { () } & 2 & \text { () } & 1 & 30 \\ \text { () } & 2 & \text { () } & 1 & 31 \\ \text { () } & 2 & \text { () } & 1 & 32\end{array}$


S. v.p. doorgaan op de volgende bladzijide. 
26 Is het werk doorgaans goed georganiseerd?

$\begin{array}{rrrrr}\text { ja } & & \text { nee } & & \\ \text { () } & 1 & (1) & 2 & 33 \\ \text { () } & 1 & (1 & 2 & 34\end{array}$

27 Kunt $U$ voldoende owerleggen over Uw werk?

() 2 () 1135 onverwachte situaties?

29 Wordt $U$ in het werk geregeld gehinderd door gebreken in het werk van anderen?

() $2 \quad$ () 1136

30 Wordt UW werk vaak bemoeilijkt door af wezigheid van anderen?

\begin{tabular}{|c|c|c|}
\hline \multicolumn{2}{|l|}{$c$} & \\
\hline
\end{tabular}

31 Vindt U de onderlinge sfeer op het werk goed?

() 1 () $2 \quad 38$

32 Ergert $U$ zich waak aan anderen op het werk?

() 2 () 139

33 Werkt $U$ onder goede dagelijkse leiding?

() 1 () 240

3.4 Heeft de dagelijkse leiding een juist beeld van $U$ in Uw werk?

() 1102

35 Houdt de dagelijkse le iding voldoende rekening met wat U zegt?
() 1
( ) 2
42

36 Vindt $U$ dat het in orde is met de veilligheid in het werk?

() $\quad 1 \quad$ () $2 \quad 43$

$37 \mathrm{Zijn}$ er omstandigheden in het werk die een ongunstige invloed hebben op Uw priveleven?

38 Voelt $U$ zich in dit bedrijf voldoende gewaardeerd?
() 2
() 1
44
() 1
() 2
45

39 Vindt $U$ Uw beloning in overeenstemming met het werk dat $U$ doet?

$\begin{array}{lllll}\text { () } & 1 & (\text { ) } & 2 & 46 \\ \text { () } & 1 & \text { ( ) } & 2 & 47\end{array}$

40 Zijn Uw vooruitzichten bij deze werkgewer goed?

41 Al met al, vindt $U$ nu zelf dat $U$ goed, redelijk,

$\begin{array}{ccc}\text { goed } & (\text { ) } & 1 \\ \text { redielijk } & (\text { ) } & 2 \\ \text { matig } & (\text { ) } & 3 \\ \text { niet goed } & (\text { ) } & 4\end{array}$

NIPG / TNO

Postbus 124

2300 AC LEIDEN 
Biilage 3 Samenstelling somscores lange VAG, vragen kort aangeduid, aantal vragen aangegeven met on (i)

\section{Sonscore Inspaming $(E=15)$}

werk vank te vernoeiendl problemen met tempo of drukte wil kalmer aan doen moeite met buigen, bukken moeite met tillien, sjouwen moe ite met zitten

moei te met staan moeite met lapen moeite met trapliopen

moei te met werken in ongemakkel ijke houding moei te met ingespannen $\mathrm{kijken}$ moeite met scherp luisteren moeite met zich concentreren moeite met informatie onthouden moeite met vereiste naukeurigheid

\section{Somscore Gezondheid $(m=25)$}

laatste tijd gezondheidsklachten gehinderd door niet in orde vaelen last van benauwdheid, kortademigheid hartklachten maagk lach ten buikklachten klachten ower armen, handen $k$ lachten over benen, voeten klachten over schouders, nek pijun boven in de rug pi jn onder in de rug last wan tranende ogen problemen met scherp $z$ ien moeite met horen last van duizelingen is vergeetachtig heeft geregeld hoofdpi jn voelt $z i c h$ valak gespannen is dikwijts prikkelbar is vaak nerveus voelt zich vaak gejaagd is well eens moedeloos staat geregeld moe op slaapt slecht

kont slaap tekort 


\section{Bijlage 3 (II)}

\section{Sonscore Ziektegedrag $(n=4)$}

behandeld voor hoge bloeddruk

id. hartistrat

id. longaandoeriling*

id. inwendf ge organen*

id. allergle*

1d. rugaandoeningen*

id. andere spier/gewrichtsaandoeningen"

id. ander *

gebrulkt geregeld medicijnen

afgeloperi is masnden bij arts geweest

afgetopen zes maanden ziek thuisgebleven

* gerekend als een klacht bij een of meer keer bevestigend beantwoord

Sonscore Materiële Herkomstandigheden $(=24)$

werkpllek niet goed ingericht

veel hinder van kou

id. warmte

id. wisseling in temoeratuur

id. droge lucht

id. vochtige lucht, regen

id. tocht, wind

id. gebrek aan frisse lucht

id. Lawaa i

id. mechanische trillingen

id. onvoldoende verlichting

id. ongeschikte vertichting

id. damp, nevel

id. rook

id. stank

id. stof

id. vuil, smeer

beschermingsmiddelen niet in orde

verdere veiligheid niet in orde

ervaringen veitigheidsfunctionar is niet gunstig

werkkleding niet in orde

sanitaire vaorzieningen niet in orde

kleedruintes niet in orde

cantinevoorzieningen niet in orde 
Somscore Taak en Verkorganilsatie $(n=22)$

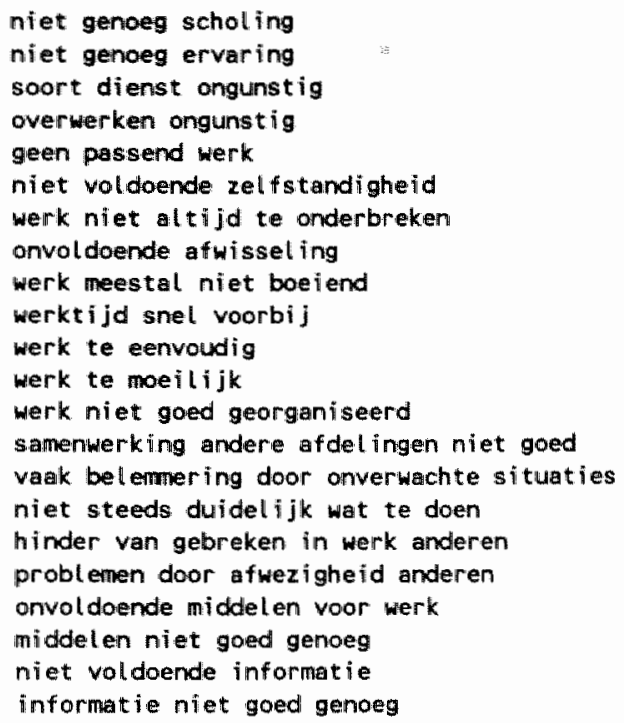

Somscore Leiding en Collega's $(a=17)$

onder linge sfeer nilet goed

kan geen beroep op coll legal's doen

ergert zich aan anderen op werk

geen goede dagel $i j k s e$ leiding

leiding geen juist beeld van werknemer

leiding houdit geen rekening met werknemer

leiding ondersteunt niet voldoende

werk is niet billijk verdeeld

wordt teveel op de vingers gekeken

krijgt onwoldoende informatie

anvoldoende overleg over werk

werkbesprekingen lopen niet goed

vergaderingen lopen niet goed

samenwerking loopt niet goed

vaak meningsverschill over kwalliteit werk

onvoldoende contacten met anderen

meestal geen plezier in het werk 
Bilage 3 (IV en slot)

Somscore Whardaring voor de lerkkring $\left(w_{1}=10\right)$

woet $z$ ich onwoldowde gewardeerd

bedrilf niat goed geleid

or werlte niet goed

geen goed bedir If om in te werken

onvoldoende zekerheid in werkkring

wordt niet bi LIJk behandeld

bel oning niet in overeensteming met werk

voorultzichten niet goed

verwacht ongunstige veranderingen

zoekt ander werk

\section{Conditien $(\omega=44)$}

Som wan Inspaning, Gezondheid en ziektegedrag

\section{Herksituatie1 $(m=73)$}

Som van Materiüle Werkomstandigheden, Taak en

Werkorganisatie, Leiding en Collega's en Waardering voor de Werkkiring

\section{Total sore $(n=117)$}

Som wan Conditie 
Billage 4 splitsing VAG-kort in twee indices: Conditiek en Werksituatief, ittens kort aangegeven; aantal vragen aangegeven met in (i)

Conditie $e_{k}(m=15)$

werk lichemel $i j k$ inspannend

werk geestel $i j k$ inspannend

geregeld onder $t i j d s d r u k$

werk valak te vermoeiend

problemen tempo of drukte

will kalmer aan doen

theeft gezondheidsklachten

is vaak gespannen

is vaak nerveus

voelt $z$ ich vaak gejaagd

is wel eens moedeloos

gebruikt medicijnen

bij arts geweest

behandeld hoge bloeddruk*

id. hart/vat*

id. Longaandoening*

id. inwendlige organen*

id. allergile*

id. rugaandoening*

id. andere spier/gewricht ${ }^{*}$

id. anders*

ziek thuisgebleven

* gerekend als een klacht, indien éen of meer keren bevestigend beantwoord. 


\section{Bilage 4 (II)}

Werksit tuatiek $($ 用 $=25$ )

niet genoeg scholling

niet genoeg fillissel ing

werk niet boeilend

geen plezier in werk

werk te eernoudig

hinder wissel ling temperatur

hinder droge lucht

gebrek an frisse lucht

hinder van llawaa

Hinder van stank

werk niet goed gearganilseerd

onwaldoende overleg aver werk

vaak onverwachte situaties

last gebrekkig werk anderen

problemen door afwezigheid anderen

onderlinge sfeer niet goed

ergert zich an anderen op werk

geen goede dagel 1 jikse leiding

lelding geen juist beeld werknemer

leiding onvoldoende rekening werknemer

veiligheid niet in orde

ongunstïge invloed werk-privéleven

woelt $z i \mathrm{ch}$ anvoldoende gewardeerd

beloning niet in overeensteming werk

voorultzichten zijn miet goed 
Bijlage 5 Ligging van de grenswaarden binnen de verklarende variabelen: aangegeven zijn de cumulatieve percentages en de in de tekst gebruikte aandulding van de girenzen (20/80 etc. $)^{*}$ (1)

VERZUIMPERCENTAGE

$0.0 \% \quad 20 / 80$

$0-1.4 \% 30 / 70$

$0-2.5 \% \quad 40 / 60$

- $3.8 \% \quad 50 / 50$

$0-5.8 \% \quad 60 / 40$

$0=8.5 \% \quad 70 / 30$

$0=12.1 \% \quad 80 / 20$

$0-19.7 \% \quad 90 / 10$

I NISPANN ING

$\begin{array}{rr}0 \% & 28 / 72 \\ 0-7 \% & 46 / 54 \\ 0-13 \% & 60 / 40 \\ 0-20 \% & 80 / 20 \\ 0-27 \% & 86 / 14\end{array}$

ZIEKTEGEDRAG

$\begin{array}{rr}0 \% & 32 / 68 \\ 0=25 \% & 54 / 46 \\ 0-50 \% & 77 / 23 \\ 0-75 \% & 93 / 07\end{array}$

CONOITIE

$\begin{array}{rr}0 \% & 10 / 90 \\ 0-7 \% & 20 / 80 \\ 0-13 \% & 30 / 70 \\ 0-20 \% & 40 / 60 \\ 0-27 \% & 50 / 50 \\ 0-33 \% & 60 / 40 \\ 0-40 \% & 70 / 30 \\ 0-47 \% & 80 / 20 \\ 0-60 \% & 90 / 10\end{array}$

\section{VERZUIMFREOUENTIE}

$\begin{array}{rr}0 & 21 / 79 \\ 0-1 & 45 / 55 \\ 0=2 & 65 / 35 \\ 0-3 & 79 / 21 \\ 0-4 & 88 / 12\end{array}$

GEZONDHEID

$\begin{array}{rr}0 \% & 20 / 80 \\ 0=4 \% & 32 / 68 \\ 0=8 \% & 41 / 59 \\ 0=12 \% & 50 / 50 \\ 0=15 \% & 57 / 43 \\ 0=19 \% & 70 / 30 \\ 0=31 \% & 80 / 20 \\ 0=42 \% & 90 / 10\end{array}$

CONDITIE!

$\begin{array}{ll}0 \% & 08 / 92 \\ 0=2 \% & 16 / 84 \\ 0=7 \% & 30 / 70 \\ 0=9 \% & 36 / 64 \\ 0=13 \% & 47 / 53 \\ 0=18 \% & 57 / 43 \\ 0=24 \% & 74 / 26 \\ 0=31 \% & 80 / 20 \\ 0=42 \% & 90 / 10\end{array}$

WERKS I TUATIE $k$

$\begin{array}{rr}0-4 \% & 10 / 90 \\ 0-12 \% & 20 / 80 \\ 0-16 \% & 30 / 70 \\ 0-24 \% & 40 / 60 \\ 0=28 \% & 50 / 50 \\ 0-32 \% & 60 / 40 \\ 0-40 \% & 70 / 30 \\ 0-48 \% & 80 / 20 \\ 0-60 \% & 90 / 10\end{array}$




\section{Biilage 5 (1)}

\begin{tabular}{|c|c|c|c|c|}
\hline \multicolumn{3}{|c|}{ VAG kort } & \multicolumn{2}{|c|}{ WERKSITATIE } \\
\hline & - $8 \%$ & $12 / 88$ & $0-4 \%$ & $10 / 90$ \\
\hline 0 & $=13 \%$ & $22 / 78$ & $0-8 x$ & $21 / 79$ \\
\hline 0 & $=18 \%$ & $32 / 68$ & $0-114$ & $29 / 71$ \\
\hline 0 & $-23 \%$ & $42 / 58$ & $0-15 x$ & $40 / 60$ \\
\hline 0 & $-25 \%$ & $48 / 52$ & $0-19 x$ & $52 / 48$ \\
\hline 0 & $-30 \%$ & $58 / 42$ & $0-24 x$ & $62 / 38$ \\
\hline 0 & $-35 \%$ & $68 / 32$ & $0=28 x$ & $71 / 29$ \\
\hline 0 & $-43 \%$ & $\mathrm{BO} / 20$ & $0-33 x$ & $80 / 20$ \\
\hline 0 & $-50 \%$ & $90 / 10$ & $0-43 x$ & $90 / 10$ \\
\hline
\end{tabular}

* Voorbeeld verzuimpercentage. $20 \%$ van de werknemers heeft een verzuimpercentage van $0 \%$, deze worden gecontrasteerd met de $80 x$ van de werknemers die een percentage van meer dan $0 \%$ hebben (aungegeven als 20/80); 30\% van de werknemers heeft een verzuimpercentuge van $0-1.4 \%$, deze worden gecontrasteerd met de $70 \%$ van de werkmenters die een hager verzuimpercentage dan $1.4 \%$ hebben (aangegeven als $30 / 70$ ) en zo woort. 


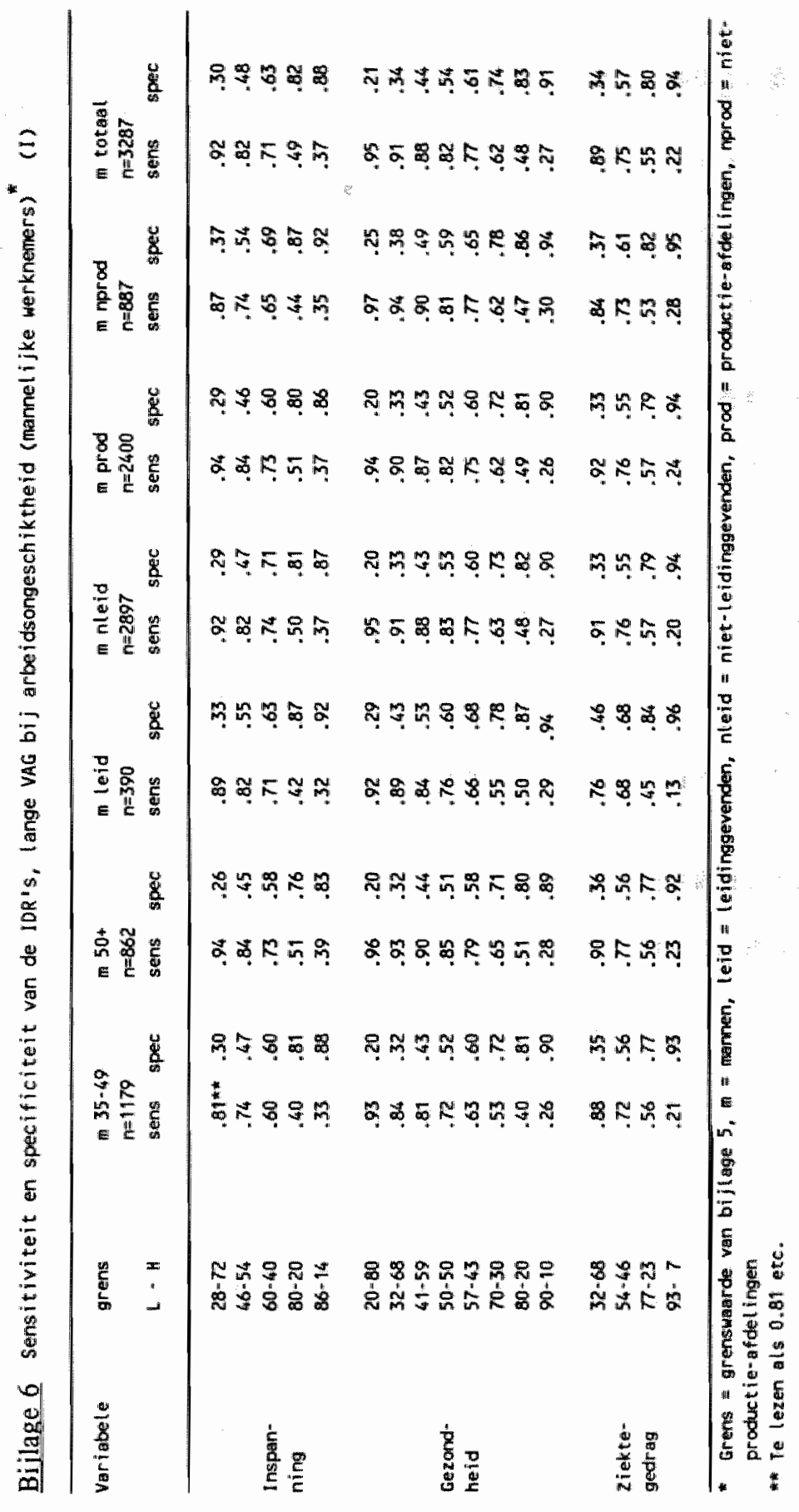




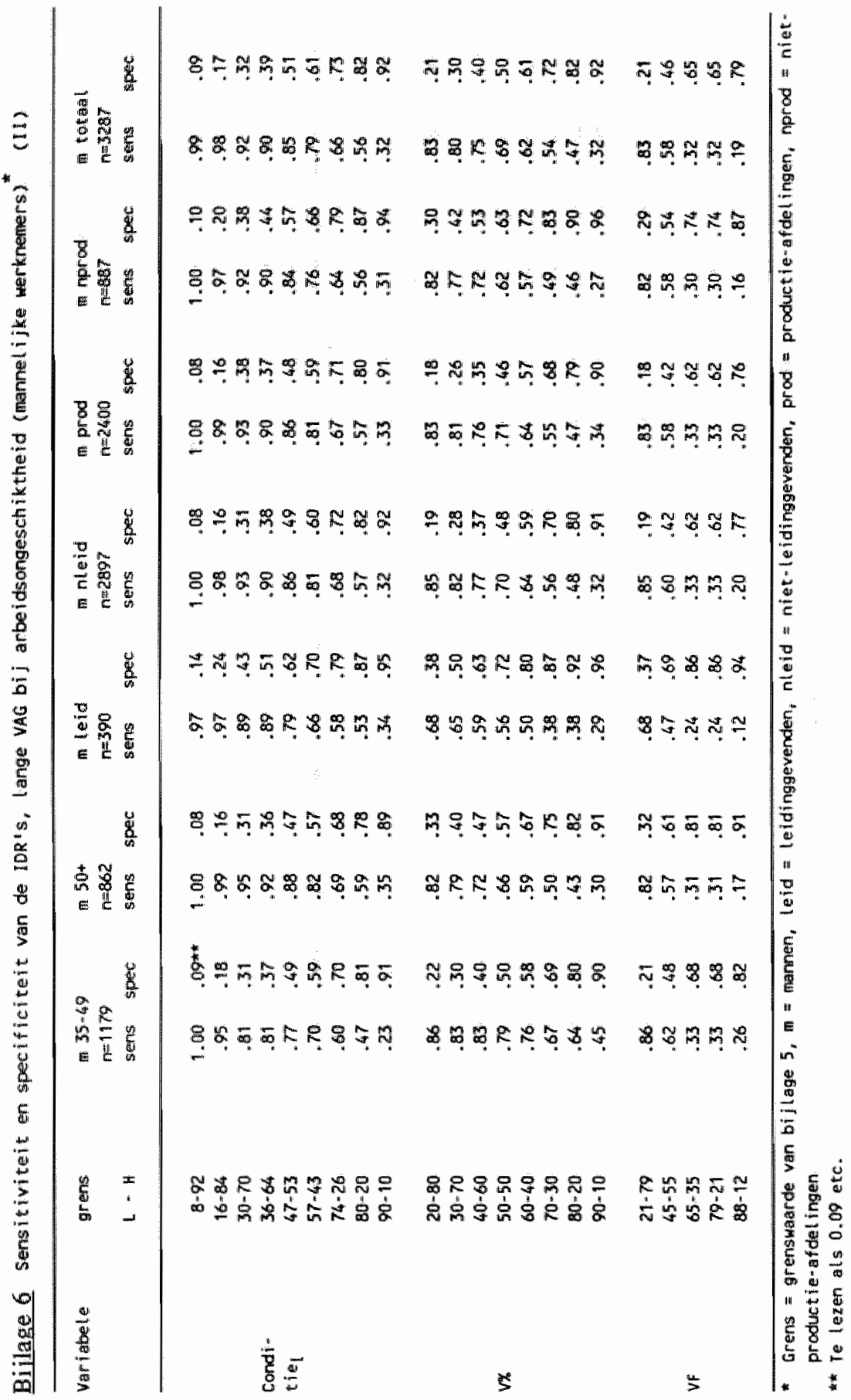


Bilage 7 Sensitiviteit en specificiteit van de IOR's $s_{*}$ lange VAG bij verveogd uitereden (mannelijke werknemers) (I)

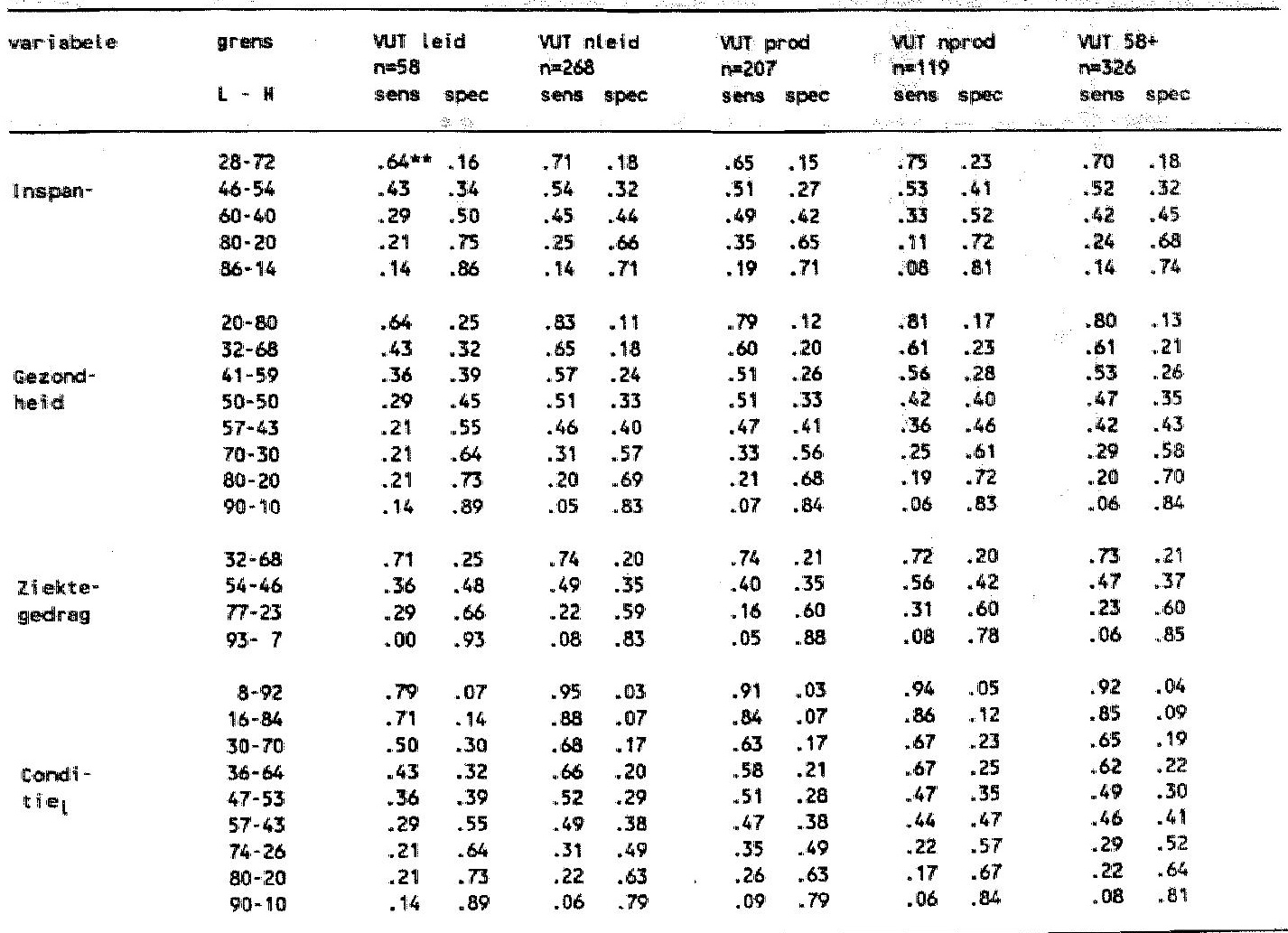

Grens = grenswaarde van bijlage 5 . Leid $=$ leidinggevenden, nieid $=$ niet-leidinggevenden prod = produthtieafdel ingen, nprod = niet-produktie-afdel ingen

Te lezen als 0.64 etc. 
Billage 7 sensitiviteit en specificitelt van de lop's lange vac bij verwroegd uittreden (mannellike werknemers)* (II)

\begin{tabular}{|c|c|c|c|c|c|c|c|c|c|c|c|}
\hline \multirow[t]{2}{*}{ Wartabeto } & \multirow{2}{*}{$\begin{array}{l}\text { grents } \\
L-4\end{array}$} & \multicolumn{2}{|c|}{$\begin{array}{l}\text { MUt } \\
n=58\end{array}$} & \multicolumn{2}{|c|}{$\begin{array}{l}n \text { ntedd } \\
n=268\end{array}$} & \multicolumn{2}{|c|}{$\begin{array}{l}\text { WT prod } \\
\text { n=207 }\end{array}$} & \multicolumn{2}{|c|}{$\begin{array}{l}\text { WUT nprod } \\
n=119\end{array}$} & \multicolumn{2}{|c|}{$\begin{array}{l}\text { MT } 584 \\
n=326\end{array}$} \\
\hline & & sensi & spect & sens & spect & suens & spex & sents & spec & sens & spec \\
\hline \multirow[t]{8}{*}{ w } & $20-80$ & .64 & .46 & .68 & .26 & .65 & .28 & .69 & .32 & .67 & .29 \\
\hline & $30-70$ & .50 & .46 & .62 & .29 & .58 & .29 & .61 & .39 & .59 & .32 \\
\hline & $40-60$ & .43 & .59 & 54 & .36 & .53 & .37 & .50 & 46 & .52 & .40 \\
\hline & $50-50$ & .43 & .62 & .40 & .41 & .35 & .42 & .47 & 50 & .41 & .45 \\
\hline & $60-40$ & 21 & .69 & .31 & .49 & .20 & .49 & .33 & 61 & .29 & .53 \\
\hline & $70 \cdot 30$ & .07 & .82 & .23 & .56 & .19 & .56 & .22 & .69 & .20 & .60 \\
\hline & $80-20$ & .07 & .85 & .18 & .34 & .14 & .64 & .19 & .74 & .16 & क Eात \\
\hline & $90-10$ & .00 & .87 & .05 & .75 & .02 & .74 & .08 & .84 & .04 & .77 \\
\hline \multirow[t]{5}{*}{ WF } & $21-79$ & +64 & .46 & .68 & .26 & .65 & .28 & .69 & .32 & .67 & .29 \\
\hline & $4.5 \cdot 55$ & .29 & .69 & .40 & .52 & .30 & .55 & .47 & .55 & .38 & .55 \\
\hline & $65-35$ & .07 & .90 & $.2 z$ & .76 & .12 & .77 & .28 & .82 & .19 & .79 \\
\hline & $79-21$ & .017 & .90 & .22 & .76 & .12 & .77 & .28 & .82 & .19 & .79 \\
\hline & $B 8-12$ & .07 & .92 & .12 & .88 & .09 & .86 & .14 & .93 & .11 & .88 \\
\hline
\end{tabular}

Grens = grenswarde wan bijlage 5. teid $=$ leidinggevenden, nleid $=$ niet:leidinggevenden, prod : produktieafdel ingen, mprod $\approx$ niet-produkt le-afdel ingen

fe lezen als 0.64 etc. 


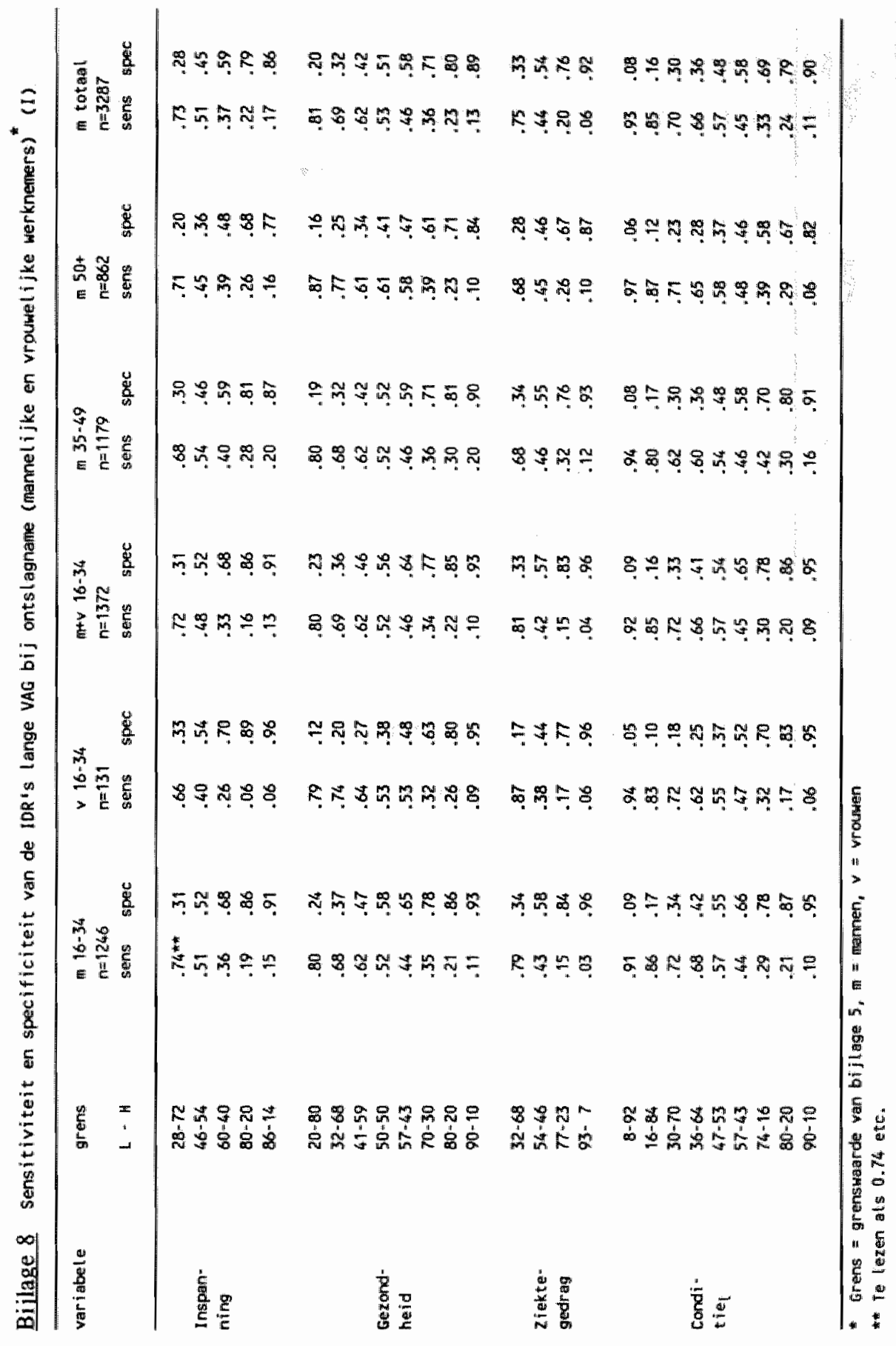




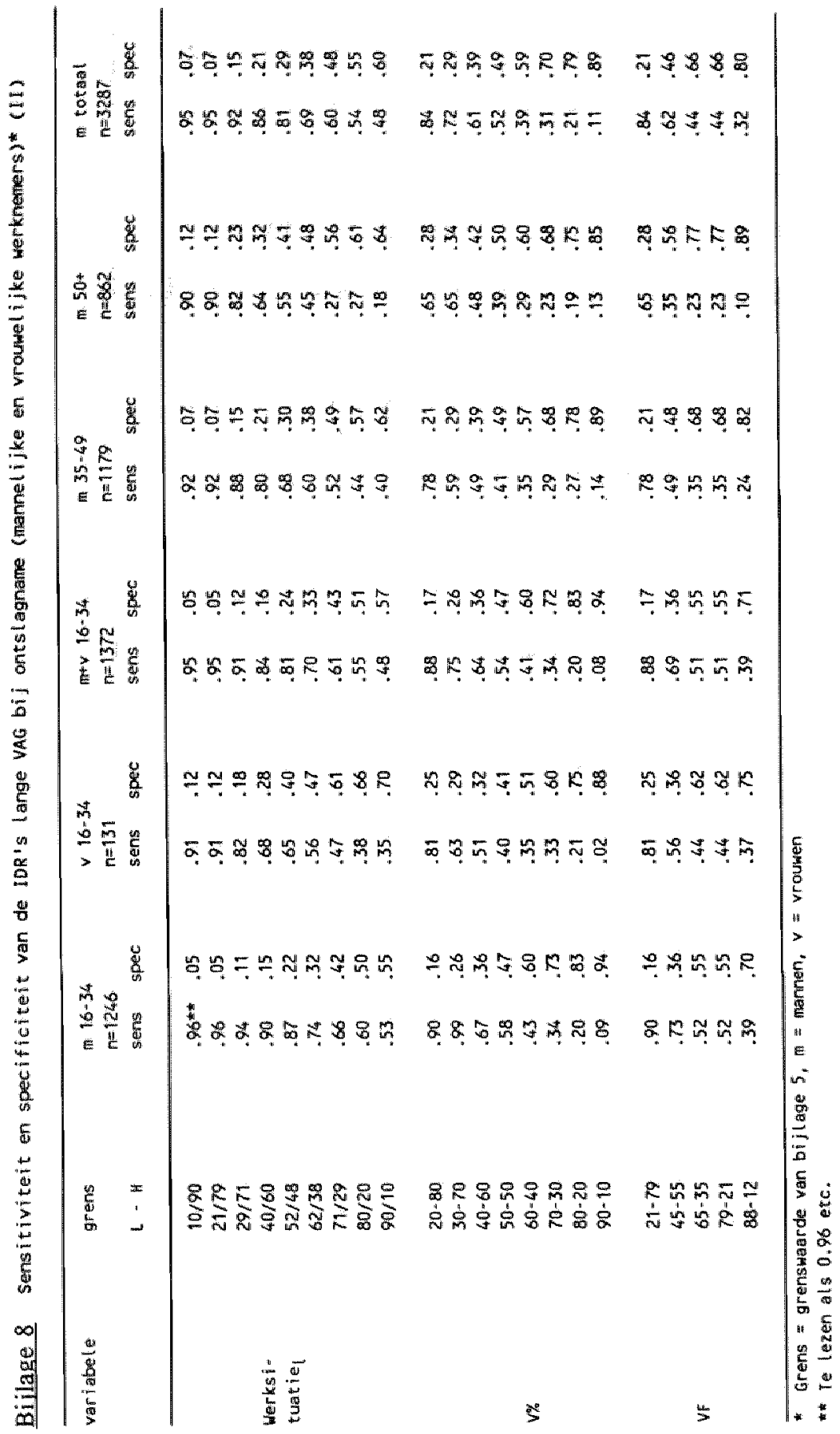




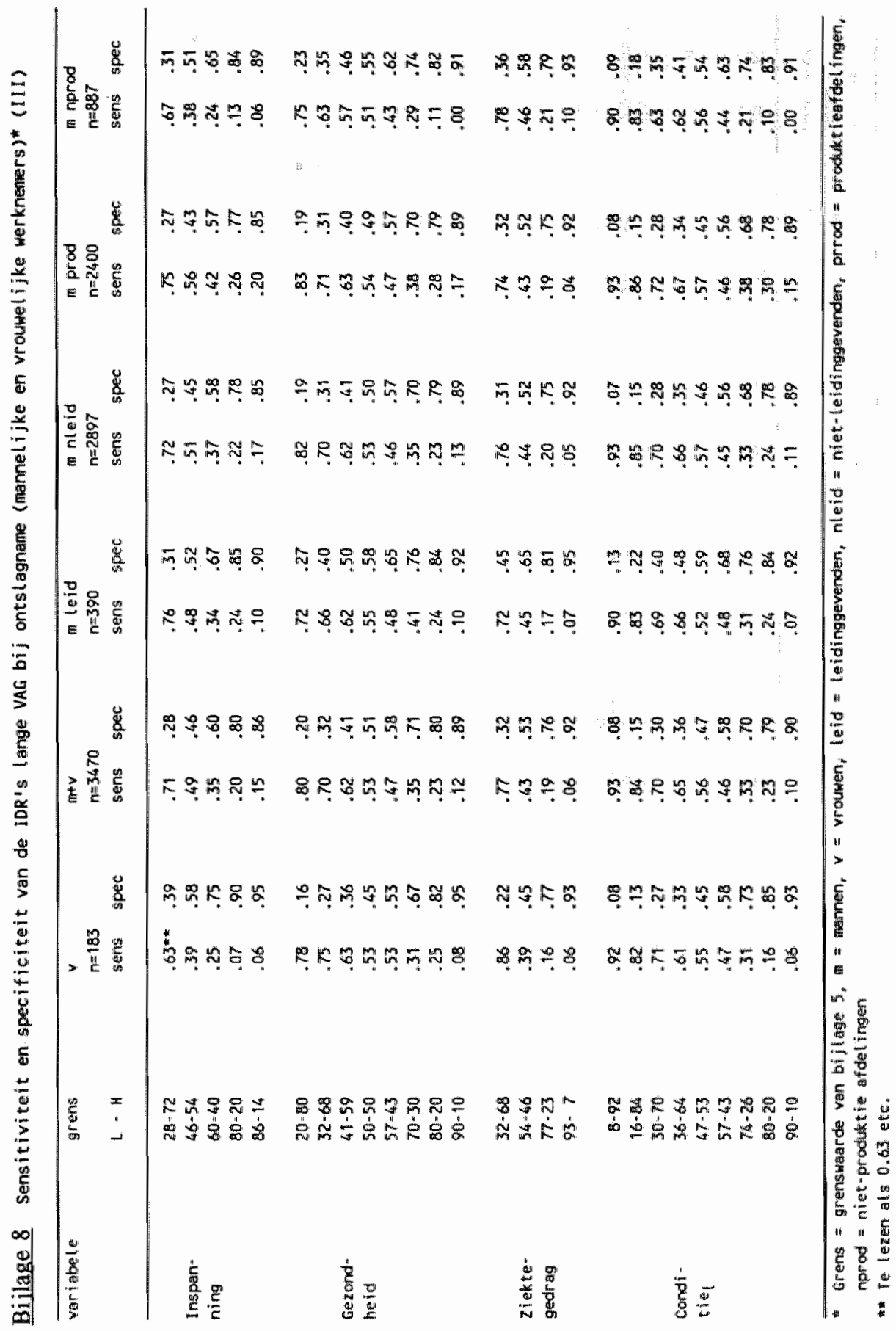




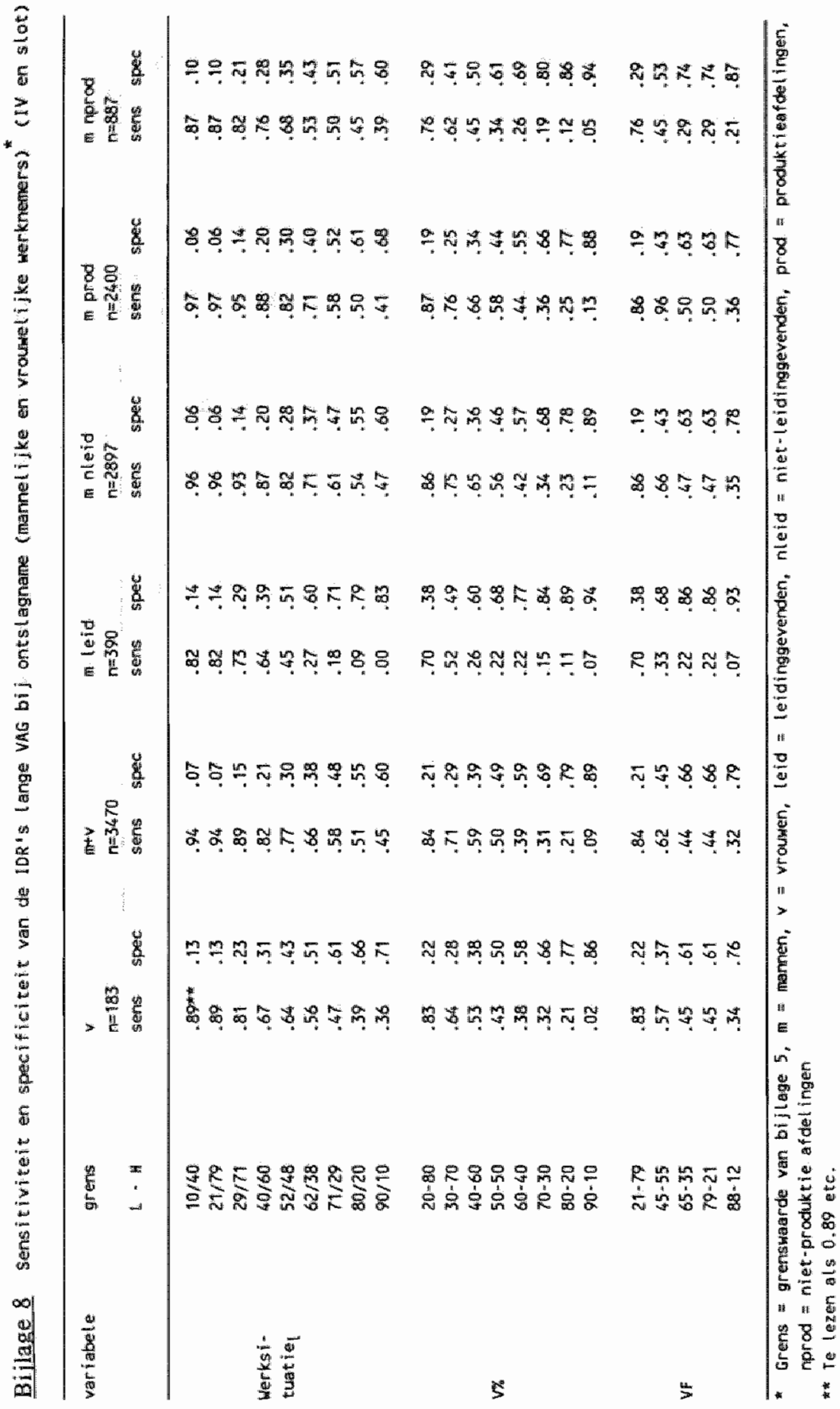




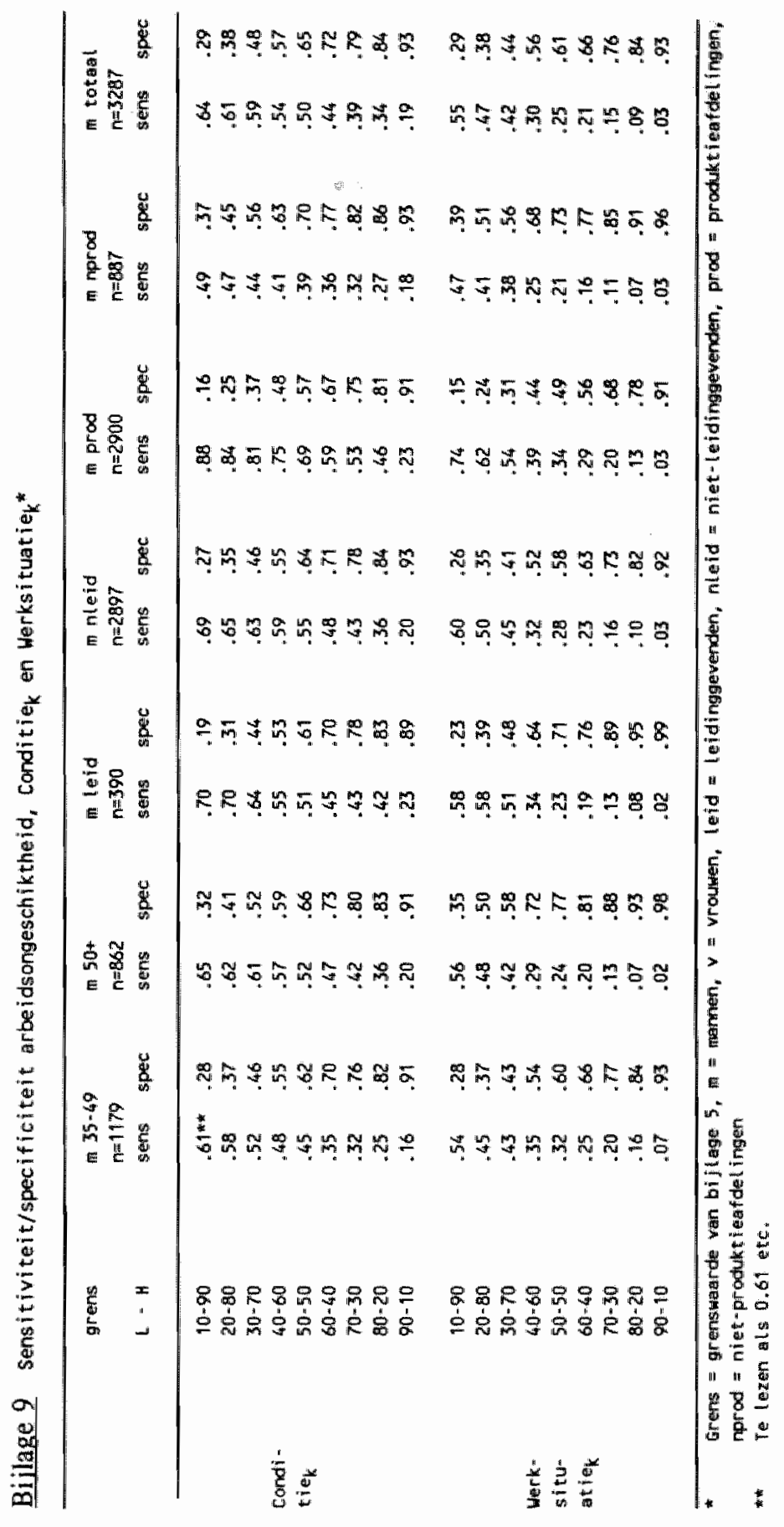



Billage 10 Sensitiviteit/specificiteit Wur "Conditiek en Werksituatie

\begin{tabular}{|c|c|c|c|c|c|c|c|c|c|c|c|}
\hline \multirow[t]{2}{*}{ variabele } & \multirow{2}{*}{$\begin{array}{l}\text { grens } \\
L \cdot H\end{array}$} & \multicolumn{2}{|c|}{$\begin{array}{l}\text { VUT leid } \\
n=58\end{array}$} & \multicolumn{2}{|c|}{$\begin{array}{l}\text { wut nleid } \\
n=268\end{array}$} & \multicolumn{2}{|c|}{$\begin{array}{l}\text { WT prod } \\
n=207\end{array}$} & \multicolumn{2}{|c|}{$\begin{array}{l}\text { MUT nprod } \\
n=119\end{array}$} & \multicolumn{2}{|c|}{$\begin{array}{l}\text { WuT } 58 * \\
n=326\end{array}$} \\
\hline & & sens & spec & sens & spec & sens & spec & sens & spec & sens & spec \\
\hline & $10-90$ & $.76^{* *}$ & .34 & .82 & .31 & .93 & .18 & .69 & 47 & .76 & .37 \\
\hline & $20-80$ & .53 & 39 & .64 & .36 & .68 & .22 & .57 & .52 & .59 & .41 \\
\hline & $30-70$ & .47 & .48 & .51 & .43 & .55 & .28 & .47 & .62 & .48 & .48 \\
\hline Condi - & $40-60$ & .41 & .58 & .45 & .49 & .48 & .37 & .41 & .66 & .42 & .55 \\
\hline \multirow[t]{8}{*}{ tiek $_{k}$} & $50-50$ & .35 & .63 & .37 & .57 & .41 & .48 & .33 & .69 & .35 & .81 \\
\hline & $60-40$ & .24 & .68 & .28 & .65 & .25 & .58 & .29 & .73 & .26 & .68 \\
\hline & $70-30$ & .24 & .69 & .21 & .70 & .20 & .64 & .22 & .76 & .20 & .72 \\
\hline & $80-20$ & .24 & .74 & .18 & .75 & .18 & .70 & .20 & .80 & .18 & .77 \\
\hline & $90-10$ & .18 & .85 & $.0 B$ & .87 & .07 & .85 & .12 & .89 & .09 & .48 \\
\hline & $10-90$ & .71 & .45 & .72 & .38 & .84 & .27 & .61 & .52 & .68 & .44 \\
\hline & $20-80$ & .53 & .56 & .53 & .50 & .66 & .41 & .41 & .62 & .50 & .55 \\
\hline & $30-70$ & .53 & .65 & .43 & .58 & .52 & .49 & .39 & .70 & .43 & .62 \\
\hline Werk- & $40-60$ & .41 & .81 & .25 & .73 & .32 & .67 & .24 & .83 & .27 & .76 \\
\hline situ- & $50-50$ & .29 & .87 & $.1 \mathrm{~B}$ & .78 & .25 & .73 & .16 & .87 & .19 & .80 \\
\hline \multirow[t]{4}{*}{ atie $k$} & $60-40$ & .24 & .09 & .14 & .83 & .20 & .78 & .12 & .91 & .15 & .85 \\
\hline & $70-30$ & .12 & 95 & .07 & .90 & .09 & .89 & .06 & .95 & .07 & .92 \\
\hline & $80-20$ & .12 & 97 & .03 & .95 & .05 & .93 & .04 & .97 & .04 & .95 \\
\hline & $90-10$ & 00 & 1.00 & .01 & .99 & .02 & .99 & .00 & 1.00 & .01 & .99 \\
\hline
\end{tabular}

* Grens = grenswarde van bijlage 5 , leid = leidinggevenden, nleid $=$ niet-leidinggevenden, prod $=$ produkt i eafdelingen, nprod $=$ niet-produkt i eafdel ingen

* Te lezen als 0.76 etc. 



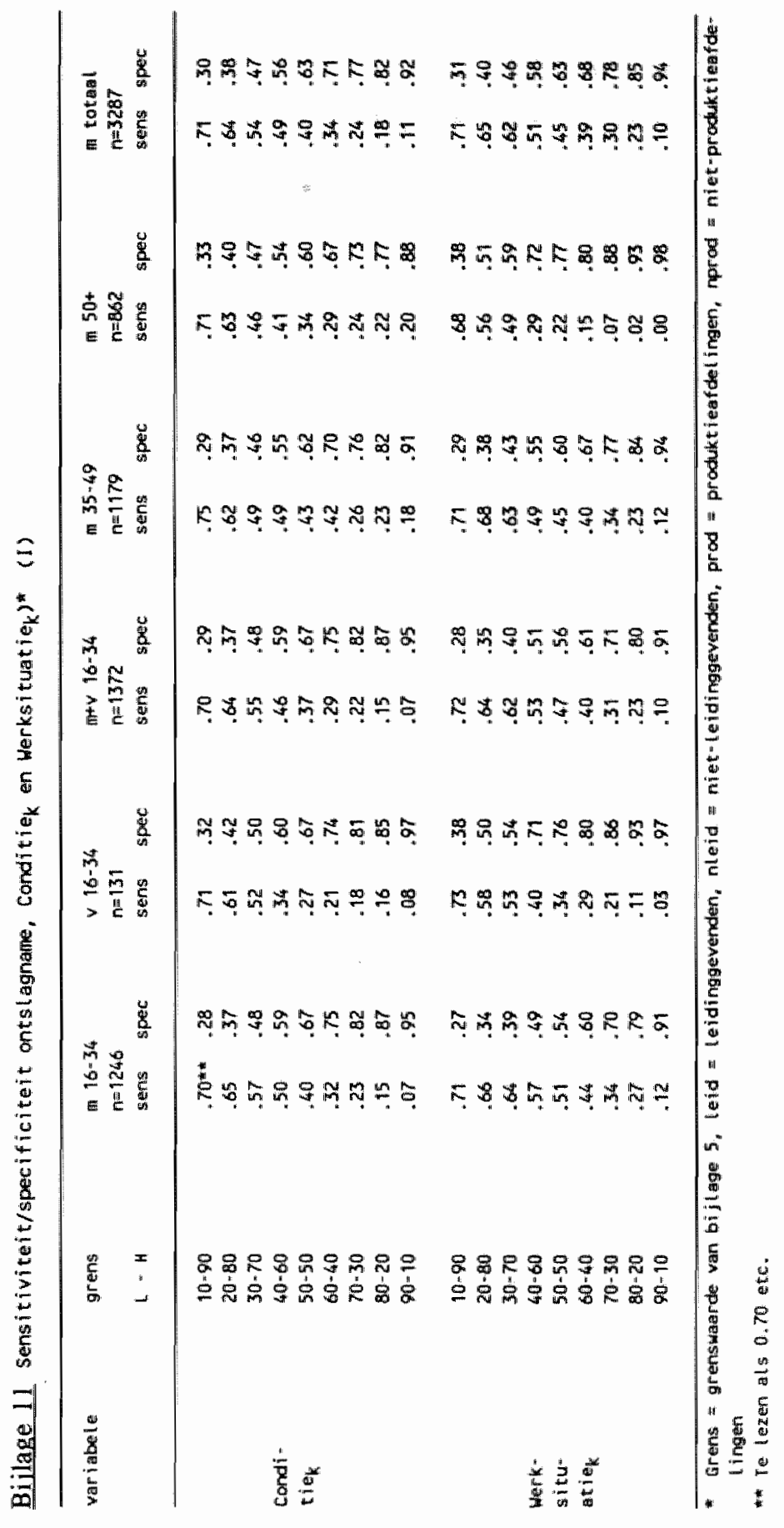




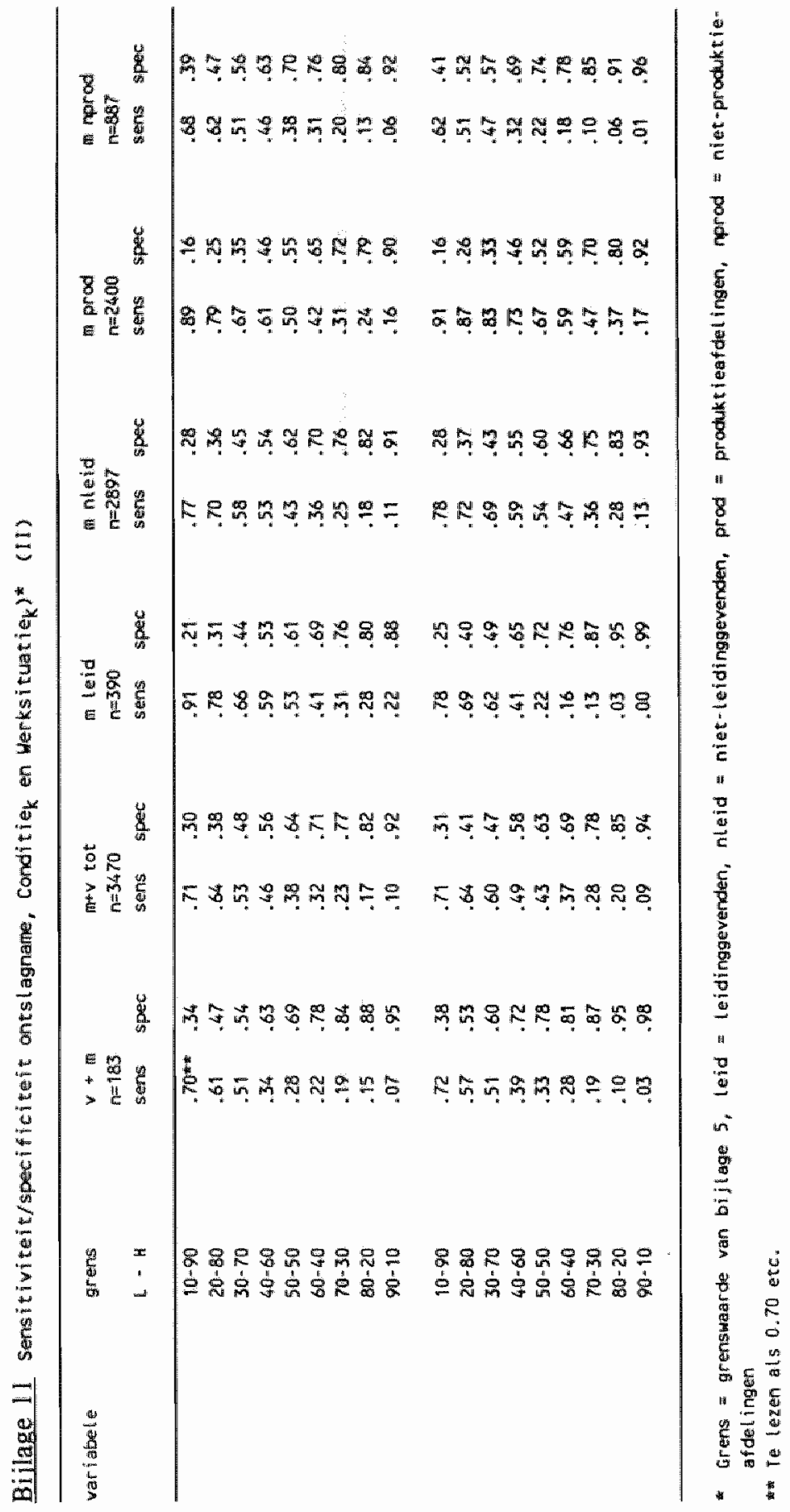




\section{CURRICULUM VITAE}

De auteur van dit proefschrift werd op 17 december 1937 te 's-Gravenhage geboren. Hij volgde de lagere school en MULO te Rijswijk ( $\mathrm{ZH}$ ), vervulde zijn militaire dienstplicht van 1957-1959 en deed Staatsexamen HBS-B in 1960.

Vervolgens studeerde hij psychologie aan Rijksuniversiteit te Leiden, waar hij in 1968 het doctoraalexamen aflegde. Sindsdien is hij werkzaam bij het Nederlands Instituut voor Praeventieve Gezondheidszorg/TNO, aanvankelijk op het gebied van veiligheid en ongevallen, later op het gebied van arbeid en gezondheid. 
